\title{
UNIVERSIDADE DE SÃO PAULO INSTITUTO DE PSICOLOGIA
}

CLÁUDIO KAZUO AKIMOTO JÚNIOR

Potencial Iatrogênico da PSICANÁlise

SÃO PAULO

2016 


\section{Potencial IATrogênico da Psicanálise}

VERSÃO CORRIGIDA

Dissertação apresentada ao Instituto de Psicologia da Universidade de São Paulo, como parte dos requisitos para obtenção do grau de Mestre em Psicologia.

Área de concentração:

Psicologia Clínica - Investigações em Psicanálise

Orientadora: Profa. Dra. Maria Lívia Tourinho Moretto

\section{SÃO PAULO}

2016 
AUTORIZO A REPRODUÇÃO E DIVULGAÇÃO TOTAL OU PARCIAL DESTE TRABALHO, POR QUALQUER MEIO CONVENCIONAL OU ELETRÔNICO, PARA FINS DE ESTUDO E PESQUISA, DESDE QUE CITADA A FONTE.

Catalogação na publicação Biblioteca Dante Moreira Leite Instituto de Psicologia da Universidade de São Paulo

Akimoto Júnior, Cláudio Kazuo.

Potencial Iatrogênico da Psicanálise / Cláudio Kazuo Akimoto Júnior; orientadora Maria Lívia Tourinho Moretto. -- São Paulo, 2016. $282 \mathrm{f}$.

Dissertação (Mestrado - Programa de Pós-Graduação em Psicologia. Área de Concentração: Psicologia Clínica) - Instituto de Psicologia da Universidade de São Paulo.

1. Psicanálise 2. Poder 3. Iatrogenia 4. Efeitos iatrogênicos 5. Responsabilidade 6. Formação do psicanalista I. Título.

RC504 
Nome: AKIMOTO JR., CláUdio KAZUO

Título: Potencial IATROGÊNICO Da PSICANÁLISE

Dissertação apresentada ao Instituto de Psicologia da Universidade de São Paulo para obtenção do título de Mestre em Psicologia

Aprovado em:

Banca examinadora

Prof. Dr.

Instituição:

Assinatura:

Prof. Dr.

Instituição:

Assinatura:

Prof. Dr.

Instituição:

Assinatura:

Prof. Dr.

Instituição: Assinatura: 
Dedico esse trabalho à minha mãe, Semíramis, e meu pai, Cláudio, pelo amor incondicional que sempre nutriram por mim e por tudo que me proporcionaram ao longo de minha vida, sendo os principais responsáveis por essa conquista. 


\section{AGRADECIMENTOS}

Primeiramente, agradeço a Maria Livia Tourinho Moretto, orientadora desta pesquisa. Agradeço por aceitar orientar e compartilhar comigo essa aposta e desafio de conduzir a pesquisa sobre este tema, sempre me apoiando e estimulando a enfrentar as dificuldades e resistências encontradas no percurso de pesquisa.

A Christian Dunker, pela participação na banca, pela leitura atenta e crítica deste texto, pelos comentários ao trabalho, provocações e debates tão produtivos, que tiveram impacto essencial nos rumos dessa pesquisa.

A Mario Eduardo Costa Pereira, pela participação na banca, pela leitura atenta e cuidadosa do texto, e pelos comentários feitos no momento da banca de qualificação, que tanto contribuíram para a evolução da pesquisa.

A CAPES pela bolsa concedida que possibilitou a realização desse trabalho

Ao Departamento de Psicologia Clínica do IPUSP, que me acolheu durante os anos de graduação e pós-graduação. Agradeço aos docentes do departamento que se fizeram presentes ao longo de minha formação. E agradeço especialmente à Claúdia Rocha e Ana Maria Garcia, pela paciência, atenção e minúcia com que sempre estiveram disponíveis para ajudar a transpor os entraves burocráticos ao longo da pesquisa.

Agradeço especialmente aos meus professores orientadores de iniciação científica ao longo da graduação, e que tanto contribuíram para meus primeiros passos como pesquisador: a Vera Paiva, por me transmitir a importância do valor político e transformador das pesquisas conduzidas na Universidade; a Helena Bicalho, pela atenção e rigor com que me conduziu pelas primeiras leituras em Lacan, despertando em mim o desejo e interesse pela psicanálise; e a Daniel Kupermann, por me ensinar como a investigação em psicanálise pode ser também sensível e bem humorada.

Aos amigos do grupo de orientação que com sua leitura, comentários e sugestões, por me escutarem e ajudarem nos momentos de maior angústia e ansiedade na condução da pesquisa: Marcos Vinícius Brunhari, Luciana Chagas, Felipe Nishioka, Mayra Xavier, Júlia Catani, Isabela Ledo e Eliane Dias. Obrigado.

A Paulo Beer e Rafael Alves Lima, pelas contribuições que fizeram ao trabalho, já na derradeira hora, oferecendo os toques finais e possibilitando que se encaminhasse para $o$ encerramento.

A toda equipe Your ID Store, em especial, Anderson, Dilson, Bruno, Dorfo, Thiago e Andresa, pelos momentos vividos, pelo apoio e suporte durante minha graduação.

A todos da família G-8, por todos os momentos que compartilhamos ao longo de mais de uma década juntos, por sempre estarem presentes nos momentos mais importantes, por todo apoio e por saberem compreender e aceitar com paciência os momentos em que estive ausente: Daniel e Luciana, Danilo e Simone, Gabriel e Carol, Luis e Ingryd, 
Wellington e Gabriela, Fabio e Rosana, William e Mayra, e as pequenas Rafaela, Luisa e Helena.

Aos amigos do Facção 178, pelas mensagens e e-mails diários, pelas piadas, debates e discussões sobre futebol, sempre uma certeza de risadas e distração, mesmo nos momentos mais árduos dessa pesquisa: Bruno Gozzi, Bruno Frullani, Diego Montanheiro, Guilherme Machado, André Halley, Henrique Galkowicz, João Frassetto, Cícero Sordi e José Eduardo Tavanti.

A Leonardo Molina e Marcelo Orefice, amigos de tantos anos, agradeço pela amizade que se manteve ao longo de tanto tempo e tantas mudanças.

A Mariana Desenzi, Dafny Silva e Elisa Penna, por terem me recebido com tanto carinho no IP-USP, agradeço pela amizade, pelas risadas e tantos momentos alegres.

Aos amigos do TIME futsal psico-USP: Pedro O., Vini Carbone, Gnomo, Bolage, Capim, Erick, Martin, Renatão. E, em especial, a Felipe Dylon, Rafael Monzen, Thiago Badari e Waldir Neto, professores dentro das quatro linhas, que encararam corajosamente o desafio de tentar me ensinar algo sobre o futebol.

Aos amigos da Psico, por tantos momentos compartilhados ao longo desses anos, pelas viagens, conversas, festas e risadas: Daniel Quatorze, Paula Barreto, Fernanda Nardoni, Flávia De Rosso, Antonio Capezutto, Marina Trombim, Stanley Gilman, Iago Hamann, Felipe Martins, Franco Cornaglia, Kim Anker, Luiza Macedo, Beatriz Campos, Lucas Alves e Thales Paiva.

A Beatriz Trabanco, primeira leitora desse trabalho, agradeço pelas críticas, pelas conversas e pelas discussões acaloradas.

A Ivan Cruz, por todas as conversas e trocas ao longo do desenvolvimento da pesquisa. Suas contribuições foram essenciais para o avanço da pesquisa no momento de maior dificuldade e estão presentes neste texto.

A Elton Souza, pela amizade e por compartilhar comigo essa aventura do mestrado e também o desafio de abrir nossa clínica. Agradeço pelas conversas, discussões clínicas e debates sobre os rumos da pesquisa.

Aos demais amigos da clínica Tecerato, por enfrentarmos juntos os desafios do dia-adia: Eduardo Guerra, Amanda Vieira, Guilherme Oliveira, Kito Dias.

A Cesinha Dias, pela amizade e futebol, festas e conversas, mas mais do que tudo pelos esforços conjuntos de construir uma clínica, para além da frieza dos textos teóricos.

A Daniel Assaz e Pedro Busatto, grandes amigos de conversas, viagens, festas e futebol, pelo companheirismo e pelas aventuras (e desventuras) vividas juntos.

A Rafael Barreto (Abu) e Tauana Marsola, pela amizade sincera, pela paciência, compreensão e carinho com que me ouvem. 
A Tauanna Vianna, primeira a acreditar que esse sonho poderia dar certo, o que me permitiu também acreditar.

A Maíra Mourão, pela escuta e pelas palavras que me conduziram pelos primeiros passos de investigação do inconsciente e que me permitiram elaborar o tema dessa pesquisa.

A Daniele Sanches, pelas contribuições, intervenções e indicações que me permitem estar advertido acerca do meu próprio potencial iatrogênico.

A Mauro Mendes Dias, pela escuta decidida que, acima de tudo, permite com que eu possa fazer valer minha própria voz.

A minha avó Ivanil, que desde cedo estimulou meu interesse pela pesquisa, mesmo sem que soubéssemos ainda aonde isso iria me levar.

A meus avós Kiyuziro e Keiko Akimoto, por todo o apoio ao longo de minha formação e meus estudos, possibilitando que pudesse trilhar meu caminho com segurança, qualquer que fosse o destino escolhido.

A minha irmã, Cíntia Akimoto, pela torcida incondicional.

A meu pai e minha mãe, Cláudio e Semiramis Akimoto, por todos os ensinamentos, por todo o apoio ao longo de minha vida e por todo o esforço, coragem e dedicação com que assumiram a tarefa de serem pais, sempre tendo como objetivo central propiciar tudo de melhor para mim e minha irmã.

Por fim, agradeço a Daniela Tankevicius, por todos os momentos juntos. Pelo apoio e companheirismo resiliente e por me lembrar sempre da importância de estar implicado em minhas ações, me alçando sempre a voos cada vez mais altos. Meu maior motivo de alegria e inspiração, esse trabalho não seria possível sem você. 
"Isto não é para nos enganarmos juntos com uma advertência sobre a responsabilidade na prática. Tu sabes bem que todo exercício de um poder não é somente sujeito a um erro, mas a este cúmulo de engano de ser benfeitor em seu erro."

\section{Jacques Lacan}




\section{RESUMO}

Akimoto, C. K. (2016). Potencial Iatrogênico da Psicanálise. Dissertação de Mestrado. Instituto de Psicologia, Universidade de São Paulo, São Paulo.

Este trabalho aborda o tema do potencial iatrogênico da psicanálise. Desde a Grécia Antiga, com Hipócrates, estabeleceu-se como princípio basilar das práticas de cura a necessidade de que, antes de tudo, não se deve causar mal ao paciente. Sabe-se que qualquer tratamento com potencial para curar um paciente tem também potencial de produzir efeitos iatrogênicos. Contudo, no campo da saúde mental, a pesquisa sobre o tema ainda pouco avançou, enfrentando resistência por parte dos profissionais e também obstáculos metodológicos, em particular, a falta de terminologia adequada para identificar, classificar e analisar os efeitos iatrogênicos. Pesquisas sobre o tema mostram que tratamentos em saúde mental provocam piora do quadro clínico do paciente em até $10 \%$ dos casos. Indicam também a importância da relação entre paciente e terapeuta, enquanto fonte de eficácia do tratamento, mas também fonte de produção de efeitos iatrogênicos. O presente trabalho é uma pesquisa teórica, que por meio de uma revisão sistemática da literatura sobre o tema do potencial iatrogênico da Psicanálise, visa investigar em que condições o psicanalista e/ou o tratamento psicanalítico podem produzir efeitos iatrogênicos e de que modo a formação psicanalítica pode contribuir para redução desses efeitos. Espera-se que a pesquisa sirva de base para o desenvolvimento de um esquema teórico conceitual que amplie a discussão sobre o tema do potencial iatrogênico da psicanálise. Até o momento foi possível elaborar a proposta de terminologia aplicável ao campo das iatrogenias, a partir da diferenciação entre iatrogenias dolosas e culposas, e com uso das categorias como: imperícia, negligencia e imprudência. Abordamos também a questão dos diversos usos feitos do poder no curso do tratamento, articulado ao tema da responsabilidade do psicanalista, a partir da proposta de formalização da práxis psicanalítica à semelhança de um jogo composto por três elementos - o sujeito, o saber e o sexo, tal como proposto por Jacques 
Lacan no Seminário XII. Concluímos que nas tentativas de simplificação, redução, recortes ou amputações da prática e da teoria psicanalítica é que residem os maiores riscos de aumento no potencial iatrogênico do tratamento. Espera-se que a presente pesquisa contribua de modo relevante para a construção de um esquema teórico conceitual que amplie a discussão sobre o tema da iatrogenia dos tratamentos em saúde mental, visando, em última instancia, compreender as possibilidades de redução de danos decorrentes do tratamento psicanalítico.

Palavras-chave: psicanálise, poder, iatrogenia, efeitos iatrogênicos, responsabilidade, formação do psicanalista 


\begin{abstract}
Akimoto, C. K. (2016). Iatrogenic Potential of Psychoanalysis. Dissertação de Mestrado. Instituto de Psicologia, Universidade de São Paulo, São Paulo.

This paper discusses the iatrogenic potential of psychoanalysis. Since ancient Greece, with Hippocrates, it was established as a basic principle of healing practices that, first of all, the doctor shall not cause harm to the patient. Today, it is known that any potential treatment for curing a patient also has the potential of producing iatrogenic effects. However, in the field of mental health, research on the subject has made little progress, facing resistance from professionals and methodological obstacles, particularly the lack of a proper terminology to identify, classify and analyze the iatrogenic effects. Research on the subject shows that mental health treatments may cause worsening of the clinical condition of the patient in up to $10 \%$ of cases. Researches also indicate the importance of the relationship between patient and therapist, as a source of treatment efficacy, but also as the source of iatrogenic effects. This work is a theoretical research that through a systematic review of the literature on the iatrogenic potential of psychoanalysis, aims to investigate under what conditions the analyst and/or psychoanalytic treatment may produce iatrogenic effects and how psychoanalytic training can help reduce these effects. It is hoped that this research will serve as a basis for the development of a conceptual theoretical framework to broaden the discussion on the subject of the iatrogenic potential of psychoanalysis. So far it was possible to develop a proposal of terminology applicable to the field of iatrogenic effects in mental health, based on the distinction between intentional and culpable iatrogenic, and use of categories such as malpractice, negligence and recklessness. This research also addressed the issue of the different uses made of power in the course of treatment, linked to the psychoanalyst's responsibility when conducting a treatment, based on the proposed formalization of psychoanalytic practice like a game, revolving around three elements - the subject, knowledge and sex - as proposed by Jacques Lacan, in Seminar XII. We conclude to argue that in the attempts of simplification, reduction, cuts or amputations of psychoanalytical practice and theory resides the greatest increases in iatrogenic potential of psychoanalysis. It is hoped that this research will
\end{abstract}


contribute in a relevant way for the construction of a conceptual theoretical framework to broaden the discussion on the subject of iatrogenic treatments in mental health, aimed at ultimately, understand the harm reduction opportunities arising from psychoanalytical treatment.

Key-words: psychoanalysis, power, iatrogenesis, iatrogenic effects, liability, psychoanalist training 


\section{LiSTA DE FIGURAS}

Figura 1: Representação gráfica do Deterioration Effect

Figura 2: Proposta de esquema de classificação das iatrogenias

Figura 3: Representação do sujeito sustentado pela certeza do impossível

Figura 4: Representação do Sujeito, do Saber e do Sexo, sustentados respectivamente pela certeza do impossível, pelo "quem sabe?" e pelo impossível de saber

Figura 5: Representação da relação entre analista e analisante, articulada aos três elementos do jogo: Sujeito, do Saber e do Sexo

Figura 6: Representação do Sujeito, do Saber e do Sexo, em relação ao objeto a e ao desejo (Lacan 1964-65/2006, pg. 352)

Figura 7: Representação do paciente e do analista no início do tratamento

Figura 8: Representação do sujeito endereçando sua fala ao analista .....

Figura 9: Representação da suposição de saber no analista e montagem da transferência

Figura 10: Surgimento de angústia ou incidência do desejo do analista, a partir da relação transferencial

Figura 11: Representação completa do jogo psiscanalítico no curso do tratamento

Figura 12: Articulação entre o jogo psicanalítico e as categorias iatrogênicas .... 


\section{LISTA DE SIGLAS}

DOI-CODI Destacamento de Operações de Informação - Centro de Operações de Defesa Interna

SPRJ Sociedade Psicanalítica do Rio de Janeiro

IPA Associação Psicanalítica Internacional

SPP Sociedade Psicanalítica de Paris

SFP Sociedade Francesa de Psicanálise

CPMSO Centro de Perícias Médicas e Saúde Ocupacional

ABRAP Associação Brasileira de Psicoterapia

APA American Psychological Association

CEP Centro de Educação Produtiva

IDD Iatrogenic Dependency Disorder

TCC Terapia Cognitivo-Comportamental

USP Universidade de São Paulo

IP-USP Instituto de Psicologia da Universidade de São Paulo 


\section{SUMÁRIO}

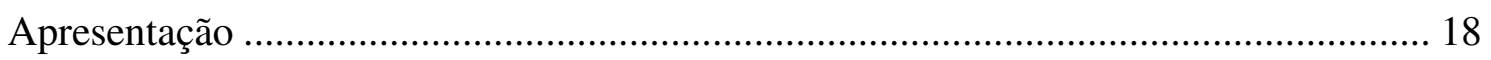

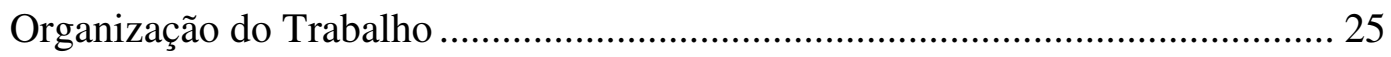

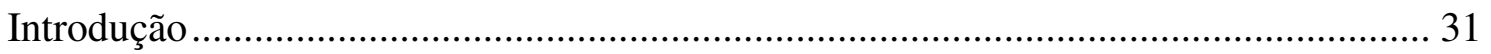

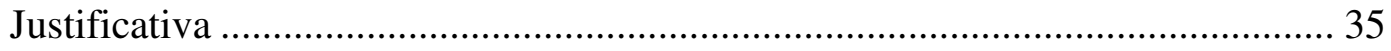

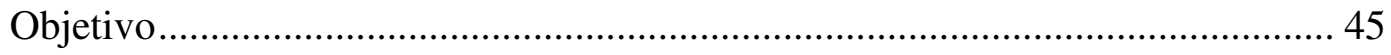

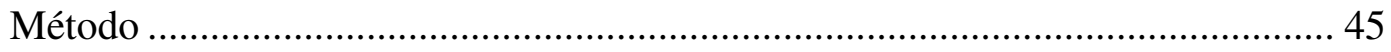

Capítulo 1 - O Potencial Iatrogênico dos Tratamentos...................................................... 47

Capítulo 2 - Dificuldades Metodológicas para pesquisa sobre potencial iatrogênico dos

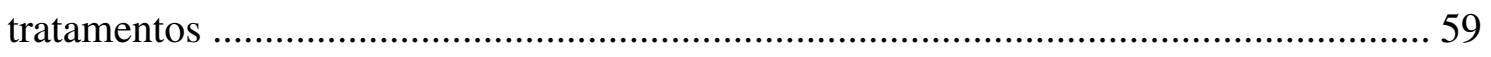

Capítulo 3 - Classificações no Campo da Iatrogenia ........................................................... 68

Capítulo 4 - O que se Sabe Sobre o Potencial Iatrogênico das Psicoterapias................. 83

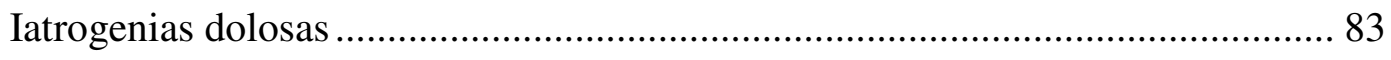

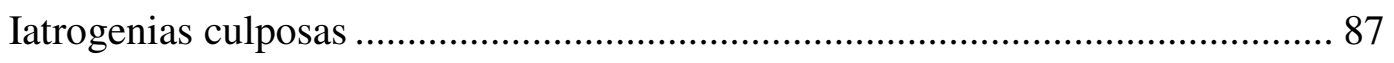

Os Possíveis Efeitos Iatrogênicos das Psicoterapias.............................................. 88

Fatores Causadores de Efeitos Iatrogênicos............................................................. 93

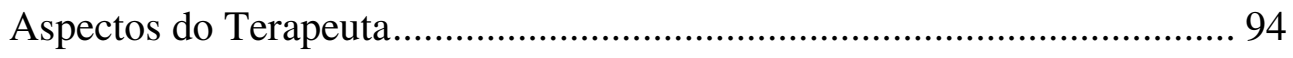

Aspectos da Personalidade do Terapeuta ………………………………....... 94

Aspectos Relacionados com o Domínio da Técnica....................................... 95

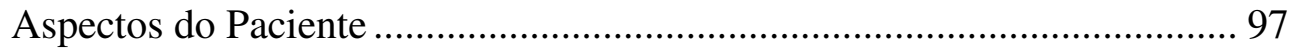

Aspectos da Relação entre Terapeuta e Paciente............................................. 99

Aspectos sociais Incontornáveis do Paciente …………………………...... 100

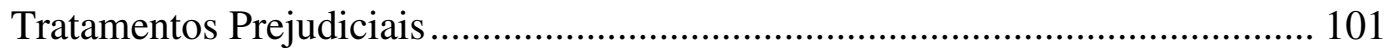


Capítulo 5 - Iatrogenia e Poder: da Psicoterapia à Psicanálise

A iatrogenia na distinção entre psicoterapias e psicanálise

O Poder como Causador de Efeitos Iatrogênicos nas Psicoterapias Autoritárias 120

Os Usos da Sugestão na Psicanálise.

A Questão do Poder na Psicanálise 138

Capítulo 6 - O Potencial Iatrogênico da Psicanálise. 150

A Formalização da Práxis Psicanalítica em Lacan 150

Contexto Histórico do Seminário 12 de Lacan 153

Qual Estatuto para o Sujeito no Tratamento Psicanalítico? 158

A Prática Psicanalítica como um Jogo 165

O Lance-a-Lance do Jogo Psicanalítico 182

Localizando as Iatrogenias no Jogo Psicanalítico 191

Capítulo 7 - A formação do analista e as possibilidades de redução do potencial iatrogênico da Psicanálise. 202

Estudo Teórico 209

Supervisão . 219

A Análise pessoal. 232

Considerações Finais 253

Referências Bibliográficas 270 


\section{APRESENTAÇão}

A presente dissertação de mestrado é o meu primeiro passo na tentativa de abordar a questão dos riscos envolvidos na condução de um tratamento psicanalítico. $\mathrm{O}$ interesse pelo tema é algo que amadureceu juntamente com o percurso de minha formação, desde a primeira graduação, em Direito, passando também pelo percurso da segunda graduação, em Psicologia, e atualmente em minha formação como psicanalista, persistindo e se modificando até o momento atual.

Desde os primeiros anos da graduação na Faculdade de Direito da Universidade de São Paulo, voltei minha atenção acadêmica e profissional para a área do Direito Civil. Dentre os diversos temas envolvidos nesse campo, em especial, o tema da responsabilidade civil no âmbito dos serviços de saúde teve grande significância em meu percurso. Além das pesquisas no campo do Direito Civil, tive a oportunidade de atuar como estagiário em um escritório de advocacia, trabalhando diretamente com processos com o tema da responsabilidade civil na área da saúde. O escritório atuava representando médicos, hospitais e planos de saúde, alvos de processos indenizatórios devido a supostos erros médicos cometidos na condução do tratamento. Tive assim um primeiro contato com o modo como eventuais erros de um tratamento são abordados na esfera judicial.

Posteriormente, já nos últimos anos de graduação, passei a atuar na esfera pública, como estagiário da Defensoria Pública do Estado de São Paulo. Pelas características desse órgão, que visa oferecer representação jurídica para a população que não pode arcar com os custos de um advogado, passei a representar juridicamente a parte contrária, os autores da ação, pessoas que buscavam no sistema jurídico uma reparação contra médicos, hospitais e planos de saúde, pelos danos que haviam sofrido por conta da má qualidade dos serviços de saúde recebidos.

Como estagiário da Defensoria, em uma época em que tal serviço ainda começava a se estabelecer no Estado de São Paulo, uma parcela grande do trabalho do estagiário consistia em realizar o contato entre a instituição e o público, realizando o 
atendimento daqueles que buscavam os serviços da Defensoria. Naquela época, minha unidade da Defensoria não contava com nenhum psicólogo na equipe e com apenas uma assistente social. Desse modo, os estagiários eram os que tinham maior contato com a população e, em consequência, acabavam absorvendo todos os tipos de demandas direcionadas à instituição. Ao receber essas pessoas para o que, ao menos em tese, seria um atendimento jurídico com intuito de recolher elementos para construção de um processo judicial, era fácil perceber que em muitos casos as demandas dirigidas à instituição e, consequentemente, aos estagiários, iam muito além de uma mera demanda jurídica.

A cada cliente atendido, a cada momento de escuta e de inclinação para ouvir suas histórias, se tornava cada vez mais claro o quanto as demandas trazidas não poderiam ser reduzidas a um problema jurídico e, consequentemente, dificilmente tais questões poderiam ser resolvidos por meio de uma decisão judicial. No mais das vezes, os processos se encerravam, mas o sofrimento perdurava, no máximo mudando de figura, sendo comuns os clientes que, alguns meses após o final de um processo, retornavam com um novo imbróglio jurídico, para propositura de uma nova ação. Demanda à instituição jurídica que se repete, mas não ser resolve.

Dessa vez não se tratava apenas das instituições de saúde envolvidas no processo, hospitais, clínicas médicas e planos de saúde que antes representava nos tempos de escritório, mas, dessa vez, me deparava com os efeitos causados pela própria instituição em que eu estava inserido, perpetuando sofrimentos ao se mostrar incapaz de identificar e acolher adequadamente as demandas que lhe eram endereçadas, resultando em perpetuação e, por vezes, até agravamento da situação enfrentada pelas pessoas que buscavam a instituição. Quando os profissionais e, consequentemente, a instituição, falham em identificar, acolher e manejar adequadamente a demanda trazida por aqueles que buscam a instituição, acabam também por contribuir para que o problema se cronifique e se agrave, vez que não encontra elaboração ou resolução. Sem dúvida, a própria estrutura da demanda dirigida à instituição, que chega de modo ambíguo e cifrado, dificulta esse processo de diagnóstico da demanda, porém, cabe à instituição 
envidar esforços para buscar mecanismos que permitam maior êxito na identificação dessas questões e na resposta oferecida a essas pessoas.

Instigado pelo que ouvia dessas pessoas e frustrado pela insuficiência do sistema jurídico em promover soluções compatíveis, após o término da graduação em Direito dei início à minha segunda graduação, agora no Instituto de Psicologia da Universidade de São Paulo. Ao longo da graduação, orientei minha formação seguindo os temas que desde antes me interessavam: as pessoas e seus sofrimentos, que pareciam não encontrar amparo nas diversas instituições, por um lado, e, por outro lado, a má qualidade dos serviços prestados por essas instituições, muitas vezes agravando a situação de pessoas que já se encontravam em dificuldades, particularmente na área da saúde.

Assim, nos primeiros anos de graduação, me envolvi em uma pesquisa na área da Psicologia Social, sob orientação da Profa. Vera Silvia Facciolla Paiva, com o objetivo de estudar como variáveis do paciente (raça, cor, sexo, gênero, classe social) poderiam afetar o trabalho dos médicos que prestavam atendimento em hospitais, impactando a qualidade dos serviços de saúde prestados (Santos, 2012). Ao longo de dois anos, foram realizadas entrevistas com médicos preceptores de um grande Hospital Público de São Paulo.

Dentre outros resultados, algo que ficava evidente na pesquisa era o modo como o racismo e o preconceito se faziam presentes dentre os profissionais, resultando em danos e prejuízos aos pacientes, mas sempre de modo velado, algo que era pouco discutido pelos médicos, sendo sempre um problema situado fora de si e apresentado como um problema do outro: do outro profissional, do outro médico, ou da instituição. A dificuldade em poder perceber e falar sobre as suas próprias possíveis falhas e limitações se mostrava presente nas entrevistas, evidenciando grande resistência dos profissionais em poder discutir a possibilidade de que seu trabalho pudesse produzir efeitos negativos para o paciente. Essa percepção viria a ter papel importante no meu percurso de pesquisa.

Paralelamente a essa atividade acadêmica, atuava também como estagiário no Projeto Rondon, uma iniciativa coordenada pelo Ministério da Defesa, com a 
participação de estudantes universitários na busca por soluções de integração social que possam contribuir para o desenvolvimento de populações carentes e aumento do bemestar social como um todo. Dentro do Projeto Rondon, diversas iniciativas são realizadas simultaneamente. $\mathrm{Eu}$ fui designado, especificamente, para um projeto realizado no centro de São Paulo e voltado para atuação junto a moradores de rua. A proposta era de buscar articular um serviço de emissão de documentos básicos para esses moradores de rua (Certidão de Nascimento, RG, CPF, Carteira de Trabalho), para que, munidos desses documentos, possam ter maior acesso aos diversos serviços públicos ou mesmo privados.

Deste modo, trabalhava em contato constante tanto com os moradores de rua do centro, quanto com as diversas instituições que, de algum modo, buscavam oferecer serviços para essas pessoas. Novamente se destacava a situação de desamparo dessas pessoas, em uma constante peregrinação em busca de uma instituição capaz de acolher suas demandas, porém, sem sucesso. Mais uma vez uma situação que se repetia e que, por vezes, era até agravada pela atuação inadequada das instituições responsáveis por receber essas pessoas.

Tal qual ocorrera anteriormente no Direito, após um início mais próximo do lado institucional e dos profissionais que prestavam os serviços, mudei de direção, voltando minha atenção, novamente, para os indivíduos usuários desses serviços. Aproximei-me da clínica, nos estágios e nas disciplinas de atendimento clínico oferecidas na faculdade, convicto da importância de privilegiar o singular de cada indivíduo que demandava a instituição em busca de alívio para seu sofrimento.

Naquele momento, cursando a graduação, tinha meus primeiros contatos com as diversas abordagens teóricas e a questão acerca dos riscos envolvidos no tratamento - e o modo como cada linha tratava disso - era um fator que impactava decisivamente o modo como eu percebia cada uma dessas abordagens. Assim, fui me aproximando cada vez mais da Psicanálise, com a convicção de que nesse campo poderia encontrar uma melhor via para tais questões, não apenas pelas possibilidades oferecidas pela psicanálise para o entendimento desse sofrimento que se dirigia à instituição e sua repetição, mas também pelos modos como o dispositivo analítico propõe mecanismos 
para acolher cada sujeito em sua singularidade, o que me parecia a via possível para algum tipo de escuta do sofrimento dessas pessoas.

Contudo, apesar desse otimismo inicial com o dispositivo psicanalítico, ao longo do curso de graduação também se acumulavam as histórias trazidas por amigos e também professores, sobre casos de condutas inadequadas ou erros cometidos por pessoas que se diziam psicanalistas, com casos de abuso, de descaso, de falta de cuidado e de falta de ética no atendimento aos pacientes. Ainda mais impressionante do que os relatos assustadores que se sucediam, era o modo como tais relatos eram apresentados, não passavam disso: meros relatos, anedotas, que se repetiam e eram narrados, de uma pessoa para outra, reproduzindo uma sensação de mal-estar e descrença, mas sem que isso fosse suficiente para repercutir em maiores tentativas de mobilização em busca de mecanismos de redução desse tipo de situações. Mais uma vez, o atendimento inadequado oferecido se repetia, produzia efeitos negativos, perpetuava ou agravava sofrimentos, sem dispositivos capazes de oferecer uma resposta a isso.

A combinação de todos esses elementos, aos poucos dava forma ao que viria a ser a principal preocupação a orientar minha investigação em nível de pós-graduação: a qualidade do cuidado e dos tratamentos oferecidos pelos psicanalistas a seus pacientes e as possíveis soluções para aprimorar o dispositivo psicanalítico visando reduzir os potenciais efeitos prejudiciais do tratamento. Como era possível que tantos casos, quase caricatos, de abusos por parte de psicanalista simplesmente transcorressem sem maiores consequências ou repercussões? Quais seriam os possíveis prejuízos que essas falhas, sejam da instituição, sejam do profissional que conduz o tratamento psicanalítico, poderiam causar a um paciente? Como algo, à primeira vista, tão inofensivo quanto escutar uma pessoa em sofrimento poderia ser causador de mais sofrimento? O que poderia ser feito para eliminar ou ao menos reduzir o risco de ocorrências desses danos?

Essas eram, de modo geral, algumas das questões que me mobilizavam quando da busca pelo mestrado em Psicologia Clínica. A partir delas, elaborei o projeto de pesquisa inicialmente apresentado, no momento de ingresso no curso de pós-graduação, que tinha como tema a questão da responsabilidade civil do psicólogo, ou seja, pesquisar que tipo de respostas e intervenções o aparato jurídico poderia dar para o 
problema dos erros cometidos por psicólogos e psicanalistas, a partir da responsabilidade que assumiam ao aceitarem tratar de seus pacientes. Tal proposta envolvia duas tarefas centrais: primeiramente, definir quais seriam os possíveis efeitos iatrogênicos decorrentes de um tratamento psicanalítico e, posteriormente, discutir quais seriam as possíveis respostas a essas ocorrências, seja no campo da psicanálise, seja no campo jurídico.

Contudo, ao longo da pesquisa e, em especial, após a realização do exame de qualificação, tornou-se evidente a necessidade de um redirecionamento do que se colocava como objetivo deste trabalho.

Em primeiro lugar, as pesquisas iniciais sobre o tema demonstraram que a busca por possíveis efeitos iatrogênicos da psicanálise seria algo impraticável. Um tipo de raciocínio que visa identificar problemas que possam ser generalizados para todos os casos para, a partir disso, extrair soluções também de caráter universal seria uma estratégia compatível com outros campos de saber, mais alinhados justamente com um discurso científico, objetivo e com pretensões universalistas. A psicanálise, porém, não se enquadra nessa descrição. Pelo contrário, sua especificidade está justamente em considerar de maneira central o sujeito em sua singularidade. Diante disso, torna-se inviável estabelecer um rol de efeitos iatrogênicos pré-determinados e aplicáveis a todos os casos. Sob a ótica da Psicanálise, o que se mostra como efeito iatrogênico em um determinado caso pode representar um ganho importante num caso distinto. Do mesmo modo, uma intervenção feita pelo psicanalista que se mostre bem sucedida com determinado paciente pode se mostrar catastrófica, caso reproduzida com outro paciente.

Uma vez percebido este primeiro ponto de impasse, colocava-se em cheque também a segunda tarefa proposta para o trabalho, ou seja, a de investigar a possibilidade de buscar no Direito as respostas para o problema dos efeitos iatrogênicos.

Ainda que se reconheça que o Estado, por meio de seu sistema judiciário, está obrigado a fornecer uma resposta judicial, caso eventualmente seja provocado por uma pessoa que ingresse com um processo contra um psicanalista, a princípio, o que se 
poderia esperar dessa resposta judicial é uma decisão com fundamentos extraídos do arcabouço teórico e técnico jurídicos e que, muito provavelmente, seriam incompatíveis com os preceitos e especificidades da prática psicanalítica.

Diante disto, como já mencionado, fez-se necessário um redirecionamento do enfoque deste trabalho para que a questão da ocorrência de iatrogenias na psicanálise e as possibilidades de sua redução fosse enfrentada não mais a partir da investigação dos possíveis efeitos iatrogênicos, mas sim de seu potencial iatrogênico, ou seja, buscar identificar quais aspectos do dispositivo psicanalítico estariam mais sujeitos a propiciar efeitos iatrogênicos, ou então, quais preceitos da prática do psicanalista poderiam aumentar os riscos de um efeito iatrogênico caso não fossem respeitados. Assim, a proposta geral é de se afastar de uma lógica científica, com relações de causa e efeito, que buscaria investigar quais são os efeitos iatrogênicos e suas causas, para passar a uma abordagem que tem como horizonte o caráter singular de cada tratamento psicanalítico e o certo aspecto de imprevisibilidade que comporta esta prática. Não se pode de antemão prever, muito menos garantir, qual será o efeito ou o desfecho de uma análise. Há, sem dúvida, uma dimensão de aposta envolvida. Porém, isso não quer dizer que não se possa investigar os elementos envolvidos nessa aposta, os aspectos que estão em jogo, visando alguma possibilidade de orientar as decisões tomadas pelo psicanalista no curso do tratamento.

A partir dessa concepção, o trabalho se distancia também de um recurso ao jurídico como resposta possível às iatrogenias no tratamento. A aposta aqui é de recorrer aos próprios psicanalistas e à responsabilidade e compromisso que cada psicanalista assume ao se dispor a escutar uma pessoa em sofrimento. A aposta de que com a investigação e pesquisa no campo da psicanálise, com a produção de um saber sobre o tema da iatrogenia no campo psicanalítico, possam ser ampliadas as possibilidades de debate sobre esse tema, impactando também o processo de formação de analistas, visando a responsabilidade na condução do tratamento, de modo a reduzir os riscos de efeitos iatrogênicos em seu curso. 


\section{Organização do Trabalho}

De modo geral, os resultados desta pesquisa serão apresentados divididos em duas partes. Considerando que os resultados da revisão bibliográfica realizada indicaram escassez de material sobre este assunto no campo psicanalítico, optou-se por uma ampliação das buscas, a fim de recolher em outras áreas do saber elementos capazes de embasar a discussão sobre o assunto no campo psicanalítico.

Assim, na primeira parte do trabalho, trata-se de discutir a própria possibilidade de ocorrência de efeitos iatrogênicos em um tratamento psicanalítico. Ou seja, antes de poder discutir quais seriam os possíveis efeitos iatrogênicos do tratamento, faz-se necessário um passo atrás para buscar verificar de que modo a psicanálise pode ou não se reconhecer como um campo sujeito à ocorrência de iatrogenias. Para isso serão apresentados elementos acerca do tema da iatrogenia, mas recolhidos em outras áreas do saber, como Medicina, Direito e psicoterapias, com o intuito de estabelecer as bases que possam sustentar uma discussão do tema no campo psicanalítico.

Já na segunda parte do trabalho, será abordada especificamente a questão do potencial iatrogênico do tratamento psicanalítico. Será feita a discussão sobre como se poderia pensar a questão dos efeitos iatrogênicos, no contexto da especificidade da prática psicanalítica, buscando identificar quais seriam os principais pontos ou aspectos do tratamento que podem ser causadores de riscos, quais seriam os possíveis efeitos esperados e, também, quais seriam os possíveis meios para redução destes riscos.

Seguindo essa divisão, na Introdução será apresentado um breve contexto das implicações envolvidas na questão do potencial iatrogênico da psicanálise. Discute-se como desde o trabalho de Freud, se coloca como questão a relação da psicanálise com outros campos de saber, em especial com o discurso científico. Com o avanço do discurso científico, em sua aliança ao discurso capitalista, a psicanálise se coloca em uma posição de resistência a esses discursos, o que também representa para si uma ameaça, sendo a psicanálise frequentemente interpelada com exigências de que faça provas de sua eficácia ou, no nosso caso, dos possíveis riscos envolvidos em sua prática. Também desde a época de Freud sabe-se que o é comum o recurso ao Direito como via 
para tentativas de subjugar a psicanálise, seja ao submetê-la a leis e regulamentos, seja ao restringir ou tornar ilegal sua prática. Discute-se como tal situação se repete ainda nos dias atuais, com maior veemência, podendo o tema dos efeitos iatrogênicos ser tomado como argumento para subjugar a psicanálise, tornando necessário que a psicanálise possa se inserir neste debate, em defesa de sua prática.

Em seguida, no Capítulo 1 é construído e apresentado o problema dos efeitos iatrogênicos e o desafio que as iatrogenias representam atualmente para a área da saúde, sendo considerada terceira maior causa de mortes nos Estados Unidos (Starfield, 2000). Discute-se a própria possibilidade de que esses efeitos iatrogênicos possam ocorrer no campo das psicoterapias, considerando que se trata de um método minimamente invasivo, que adota como base de sua técnica a fala e a escuta. Para essa discussão é retomado o debate entre Eysenck e Bergin nas décadas de 50 e 60, com destaque para o conceito de Deterioration Effect desenvolvido por Bergin, para indicar que os tratamentos psicoterapêuticos podem sim ser prejudiciais ao paciente, vez que todo tratamento com potencial para cura teria também o potencial de causar efeitos negativos ao paciente.

Uma vez reconhecida a hipótese de ocorrência de efeitos iatrogênicos nos tratamentos psicoterapêuticos, no Capítulo 2, o objetivo será de discutir os motivos pelos quais a pesquisa sobre esse tema tem avançado tão pouco. São poucas as pesquisas nessa área, mas, dentre as pesquisas existentes, resultados mostram que cerca de $10 \%$ dos pacientes sofrem piora em sua condição após o tratamento (Lambert \& Ogles, 2004). A própria literatura existente sobre o assunto destaca como a pesquisa sobre efeitos iatrogênicos enfrenta uma série de obstáculos metodológicos, sendo discutidos alguns dos principais: resistência por parte dos profissionais em abordar o tema, dificuldade dos profissionais em identificar erros cometidos, dificuldades para aferir a ocorrência de efeitos iatrogênicos, dificuldade em determinar se um efeito negativo é ou não decorrente do tratamento, dificuldade em distinguir entre efeitos iatrogênicos e efeitos negativos decorrentes do próprio curso da doença. Em especial, são destacados dois pontos que atrapalham o avanço das pesquisas sobre o tema. Em primeiro lugar, a falta de maiores investigações e debates entre os profissionais sobre 
esse tema. E em segundo lugar a falta de uma terminologia adequada que facilite a identificação, classificação e análise dos efeitos iatrogênicos ocorridos.

Reconhecendo-se a importância de estabelecimento de uma terminologia adequada para investigação no campo das iatrogenias, no capítulo 3 , a proposta é de construção dessa base terminológica, desse repertório conceitual que possibilite a investigação sobre o tema. Com esse objetivo, são resgatados elementos acerca da iatrogenia em outras áreas do saber, como a Farmacêutica, a Medicina, o Direito e as Psicoterapias, para, a partir disso, buscar tecer uma rede conceitual que possa orientar a discussão do tema no campo psicanalítico. A tese a ser sustentada é de que a iatrogenia corresponde a um grande campo que engloba diversas modalidades de danos ou efeitos não esperados que possam ser resultantes de um tratamento. No âmbito desse campo da iatrogenia, poderia ocorrer uma série de fenômenos variados, sendo importante estabelecer subcategorias dentro do campo, com critérios específicos que permitam distinguir e classificar tais fenômenos. Assim, serão abordadas questões como a distinção entre ação dolosa e ação culposa do profissional de saúde, bem como o conceito de erro médico - com os critérios de negligência, imprudência e imperícia presentes na Medicina e no Direito e sua relação com o conceito de iatrogenia. Em especial será dado destaque ao trabalho de Linden (2012), e sua elaboração de um sistema classificatório para iatrogenias no campo das psicoterapias, e que será tomado como base para construção de uma terminologia que possa ser útil também para o debate no campo psicanalítico. Tal esforço de construção de uma terminologia adequada permite um avanço importante, com a possibilidade de orientar e facilitar as pesquisas, estudos e debates sobre o tema.

Já no capítulo 4 serão apresentados os resultados da revisão bibliográfica acerca dos efeitos iatrogênicos no campo das psicoterapias. Como já mencionado, não há ainda na literatura um repertório terminológico e conceitual bem constituído, de modo que os resultados encontrados, em sua grande maioria, usam de modo intercambiável uma variedade de termos correlatos, como, por exemplo, "iatrogenia", "efeitos colaterais", “efeitos adversos", “danos, prejuízos”, dentre outros. A grande dispersão no campo das psicoterapias (Figueiredo, 1996), com diversas práticas e linhas teóricas, pautadas em 
variadas bases epistemológicas também causa confusões e contradições dentre os resultados encontrados. Feita esta ressalva, os resultados apresentados envolvem elementos potencialmente causadores de iatrogenias e serão apresentados divididos em seis categorias: aspectos do paciente; aspectos do terapeuta; aspectos da relação médicopaciente; a situação social do paciente; abusos por parte do profissional; e metodologias terapêuticas contraindicadas.

Com isso se encerra a primeira parte do trabalho e, no capítulo 5, inicia-se a passagem para a segunda parte trabalho, saindo do campo das psicoterapias para o campo da psicanálise. Toma-se como premissa a existência de uma especificidade da prática psicanalítica, que a diferencia do campo das psicoterapias e que, consequentemente, impede que os dados obtidos nas investigações no campo da psicoterapia possam ser transpostos e aplicados diretamente ao dispositivo psicanalítico. Assim sendo, neste capítulo 5 é feita a passagem da Psicoterapia à Psicanálise, tomando como eixo de discussão a questão do poder no curso do tratamento e o modo como cada um desses campos se posiciona sobre essa questão. A partir do trabalho de Maleval (2004, 2005), discute-se o modo como o uso feito pelas psicoterapias do poder conferido ao terapeuta pode ser causador de iatrogenias. Retomando desenvolvimento do trabalho de Freud, em relação ao uso da sugestão e do poder, busca-se demonstrar quais as soluções encontradas pela psicanálise lidar com essa problemática, e que podem indicar que o tratamento psicanalítico representa um menor potencial iatrogênico para o paciente.

No capítulo 6, então, o trabalho se insere especificamente no campo psicanalítico. Se reconhecemos que o dispositivo analítico, com sua especificidade acerca do modo como propõe que o analista faça uso do poder que lhe é conferido, promove um avanço no sentido de reduzir o potencial iatrogênico do tratamento, isso não significa que o tratamento esteja isento de riscos. Isso porque há sempre a hipótese de um erro por parte do analista na condução do tratamento e que venha a causar efeitos iatrogênicos ao paciente. Assim, a proposta nesse capítulo é de delimitar um modo de localizar no dispositivo psicanalítico quais seriam os principais pontos de risco de ocorrência de erros por parte do psicanalista na condução do tratamento. É tomada 
como base para a discussão a proposta apresentada por Lacan em seu Seminário 12 (1964-1965), ao formular a psicanálise como um jogo composto a partir de três elementos: sujeito, saber e sexo. Tal formulação é apresentada, discutida e, posteriormente, articulada com as categorias estabelecidas anteriormente de erro por imperícia, erro por negligência e erro por imprudência.

Por fim, no capítulo 7, a partir do que foi elaborado no capítulo anterior, é discutido de que modo pode-se pensar em medidas para buscar reduzir o potencial iatrogênico da psicanálise. Entende-se que a formação do psicanalista é a via pela qual se pode trabalhar para reduzir a ocorrência de erros na condução do tratamento. Para tanto, é necessário que o tripé da formação analítica (análise pessoal, supervisão e estudo teórico) possa também se configurar levando em consideração aspectos relativos ao potencial iatrogênico da psicanálise.

Desse modo, o presente trabalho se propõe, então, a abordar o tema do Potencial Iatrogênico da Psicanálise. Dada a escassez de pesquisas sobre o tema no campo da Psicanálise, primeiramente será feita uma busca em outras áreas do saber por fundamentos acerca dos principais elementos envolvidos nessa discussão para que, em uma segunda etapa, se possa adentrar o tema no âmbito da Psicanálise, abordando o tema que motiva a pesquisa e suas principais implicações. A proposta é de que a discussão apresentada neste trabalho sirva para construir bases para que o tema do potencial iatrogênico do tratamento psicanalítico possa se estruturar e para que a pesquisa no tema possa avançar, resultando também em mudanças no processo de formação de psicanalistas, visando meios de redução desse potencial iatrogênico.

A intenção do trabalho é de que esta pesquisa possa apresentar e sustentar, primeiramente, a possibilidade de que o psicanalista ou o tratamento psicanalítico possam produzir efeitos iatrogênicos para o paciente, seja por erro do analista na condução do tratamento, seja por um efeito iatrogênico inerente ao próprio dispositivo clínico. A partir disso, construir algum saber sobre quais seriam os principais elementos do tratamento psicanalítico suscetíveis de produzir efeitos iatrogênicos e qual seria a participação do psicanalista na produção desses efeitos iatrogênicos, bem como os possíveis mecanismos para buscar reduzir a ocorrência desses efeitos. Ademais, 
possibilitar uma discussão acerca do papel do modelo de formação psicanalítica como componente importante para redução dos possíveis riscos de danos aos pacientes.

Essa é a aposta que se faz com esse trabalho. 


\section{INTRODUÇÃo}

Desde a Grécia Antiga, com Hipócrates (460 - 370 A.C.), um dos mais importantes referenciais da história médica, conhecido como o pai da medicina ocidental (Grammaticos \& Diamantis, 2008), já se reconhecia a possibilidade de que um tratamento de saúde causasse dano ao paciente, sendo vital que aquele que conduz o tratamento, antes de mais nada, tivesse a devida cautela visando evitar ou ao menos minimizar esses danos. O juramento hipocrático, adotado até hoje na prática médica, visa estabelecer princípios éticos ou padrões de conduta capazes de orientar o exercício das práticas de cura e, também, mitigar esses potenciais efeitos nocivos. Dentre os princípios elencados nesse juramento, o primeiro e mais importante é o princípio de "não maleficência" (primun non nocere), ou seja, antes de mais nada, não se deve causar danos ao paciente, sendo esse o pilar central da ética médica (Jones, 1868).

Um segundo princípio, que recebe menos destaque, mas também de grande importância é o vulgare vulnerabilia, ou seja, a obrigação de tornar público, divulgar e informar os pacientes e a população acerca das possíveis situações de vulnerabilidade a que estão expostos, bem como os riscos envolvidos nos tratamentos e nos métodos a serem aplicados (Jones, 1868).

Considerando estes princípios, temos a orientação para que o profissional de saúde atue, antes de mais nada, evitando causar mal ao paciente para, só então, pensar em produzir resultados positivos com o tratamento, devendo, inclusive, alertar e informar o paciente sobre potenciais riscos ou perigos do tratamento que será utilizado. Implícita nessas orientações está a concepção de que uma atuação médica pode causar tanto efeitos positivos quanto efeitos negativos para o paciente e, desde os tempos da Grécia Antiga, já havia até mesmo previsão em textos legais acerca da possibilidade de responsabilização jurídica e punição do médico em caso de danos causados ao paciente no curso de um tratamento. Para os casos de morte do paciente quando o médico não seguia as práticas de cura estabelecidas, era cabível indenização pecuniária à família da 
vítima. Também o Código de Hammurabi (1970-1770 a.C.), já previa punições rigorosas ao médico, no caso de morte de pacientes (Bittar, 1991).

Atualmente, a possibilidade de danos ou prejuízos causados pelo tratamento de saúde a um paciente é comumente referida pelo conceito de iatrogenia (Tavares, 2007). Buscas em dicionários da língua portuguesa definem o termo como aquilo que se relaciona às noções de erro ou dano causado por um tratamento ou prática terapêutica ou de saúde. Em dicionários da língua portuguesa (Ferreira, 1985), a iatrogenia está definida como: "Parte da Medicina que estuda a ocorrência de doenças que se originam do tratamento de outras; patologia da terapêutica". Já o dicionário Webster da língua inglesa (Webster, 1993) em sua definição do termo iatrogenia (iatrogenesis): “(...) agora o termo se aplica a qualquer condição de que sofra um paciente como resultado de qualquer tipo de tratamento médico, como uma reação a um medicamente por exemplo.”. Neste sentido também a definição dada pelo Centro de Perícias Médicas e Saúde Ocupacional (CPMSO, 1999): "iatrogenia refere-se a um estado de doença, efeitos adversos ou complicações causadas por ou resultantes do tratamento médico ou de outro profissional de saúde".

Essas definições dão indícios de como é amplo o significado do termo, podendo englobar categorias diversas de efeitos do tratamento, como: efeitos adversos, efeitos colaterais, deterioração, complicações, dentre outros conceitos que são usados, muitas vezes, de modo quase que intercambiável na literatura (Padilha, 2001). Outro ponto importante é que o tema não diz respeito apenas a tratamentos médicos, mas também àqueles oferecidos por outros profissionais de saúde (Padilha, 2001). Para Tavares (2007, pg. 181):

"Iatrogenia (ou iatrogenose, iatrogênese) abrange, portanto, os danos materiais (uso de medicamentos, cirurgias desnecessárias, mutilações, etc.) e psicológicos (psicoiatrogenia - o comportamento, as atitudes, a palavra) causados ao paciente não só pelo médico como também por sua equipe (enfermeiros, psicólogos, assistentes sociais, fisioterapeutas, nutricionistas e demais profissionais)" 
Contudo, apesar de atualmente vinculada à noção de um efeito adverso causado por um tratamento médico, em sua origem grega, a palavra iatrogenia deriva do radical iatro ("iatrós"), que significa médico, curandeiro, remédio; e da palavra geno ("gennáo"), significando aquele que gera, que produz; e do prefixo " $I a$ ", que indica uma qualidade, ou seja, o termo iatrogenia, em sua origem, se referiria, na verdade, a efeitos causados pelo curandeiro, a toda e qualquer ação médica, todo efeito produzido por um tratamento, seja esse efeito benéfico ou prejudicial ao paciente (Tavares, 2007).

Apesar dessa noção geral acerca do significado do termo "iatrogenia", e sua aproximação atual com a noção de prejuízos causados pelo tratamento ao paciente, seu status de conceito na literatura científica ainda não está rigorosamente estabelecido (Padilha, 2001). Diversas áreas como medicina, Farmacologia, Psicologia, Direito, Sociologia, fazem uso do termo, por vezes com concepções variadas, com maior ou menor abrangência, referindo-se a fenômenos dos mais diversos. Mesmo dentro de um único campo, há disputas na literatura acerca do que exatamente poderia ser enquadrado como uma iatrogenia (Padilha, 2001).

Apesar do reconhecimento dos potenciais efeitos nocivos dos tratamentos desde tempos antigos, bem como estudos atuais que mostram o potencial nocivo dos efeitos iatrogênicos na área de saúde (Starfield, 2000), o tema da iatrogenia nem sempre é tratado com a devida relevância. No âmbito da Farmacêutica e também da Medicina, há maior proximidade e esforços no campo das pesquisas para tentativas de investigação e redução dos potenciais riscos ao paciente, buscando tratamentos cada vez menos invasivos e menos dolorosos ou com menor grau de efeitos colaterais (Padilha, 2007). Tal debate é muito comum especialmente no que diz respeito aos novos medicamentos e também em intervenções cirúrgicas, estando submetidos a uma extensa fase de testes para aferir sua segurança, antes que possam ser oferecidos amplamente. Porém, em outras áreas da saúde, que se aproximam mais da prática clínica, em especial dentre profissionais da área de saúde mental, o tema ainda é pouco abordado (Padilha, 2007).

A própria questão do déficit na pesquisa sobre efeitos iatrogênicos dos tratamentos é algo questionado na pouca literatura sobre o tema, sendo levantadas algumas possíveis explicações (Berk \& Parker, 2009). Em primeiro lugar, certa 
ignorância dos profissionais das áreas da saúde mental acerca da possibilidade de que seu tratamento possa causar mal (Boisvert \& Faust, 2007). Perdura neste campo certa noção, especialmente dentre as psicoterapias, de que por se tratar apenas de uma "conversa", de coisas ditas entre paciente e terapeuta, se trataria de um procedimento não invasivo e que, portanto, não haveria risco de danos (Nutt \& Sharpe, 2008). Um segundo problema é a tendência de profissionais da área à simplesmente não perceber ou então subestimar os danos que causam a seus pacientes, tendo maior tendência a acreditar que o tratamento que oferecem está sendo bem sucedido (Boisvert \& Faust, 2007). Em terceiro lugar, está a série de dificuldades metodológicas envolvidas no estudo do tema, como a falta de clareza terminológica que permita uma melhor comunicação sobre assunto e falta de métodos adequados para aferir e mensurar a ocorrência dos efeitos adversos (Linden, 2012).

Alguns trabalhos importantes, como os estudos de Bergin (1966), ao desenvolver o conceito de "deterioration effect", tiveram o papel relevante de comprovar experimentalmente a possibilidade de que um tratamento psicoterápico cause danos, sendo seguido por outros autores que verificaram, experimentalmente, tal possibilidade de piora do paciente após início do tratamento (Mays \& Franks, 1985; Mohr, 1995; Moos, 2005; Boisvert \& Faust, 2007; Jarret, 2007; Berk \& Parker, 2009). Porém, ainda é necessário muito avanço na pesquisa sobre o tema para que se possa, de fato, reduzir os níveis de efeitos iatrogênicos causados. Segundo a literatura atual sobre o tema, na média, cerca de $10 \%$ dos pacientes tratados com psicoterapia sofrem com efeitos iatrogênicos do tratamento (Jarret, 2007), um número bastante preocupante.

Atualmente, se fortalece cada vez mais uma busca incansável por estudos científicos que pudessem comprovar de modo experimental a eficácia dos tratamentos no campo da saúde mental. Contudo, este esforço não ocorre na mesma velocidade para o estudo dos efeitos iatrogênicos, que acabam sendo relegados para um segundo plano, o que vai contra o princípio Hipocrático de, acima de tudo, não causar mal ao paciente.

Em especial, no campo da psicanálise, as pesquisas sobre o tema são raras. Desde Freud, passando por Lacan e até os dias atuais, poucos são os trabalhos que abordam diretamente o assunto (Berk \& Parker, 2009), sendo necessário um trabalho de 
coleta de pequenos fragmentos ao longo das obras desses autores para tentar construir algo que possa dar alguma orientação acerca dos cuidados a serem tomados pelo analista para evitar efeitos iatrogênicos.

Pode-se, por exemplo, identificar questões levantadas acerca dos erros cometidos por Breuer na condução do tratamento de Anna O., ou mesmo dificuldades em outros casos relatados por Freud. Ainda em Freud (1913/1996), temos a questão acerca da importância do tratamento de ensaio para verificar as possibilidades de continuidade da análise com cada paciente, antes de se dar início ao tratamento de fato, evitando assim consequências que poderiam vir a ser traumáticas para o paciente. Mas são poucos os textos que abordam diretamente a questão dos possíveis danos causados pelo tratamento.

Sabe-se que é difundida entre os psicanalistas certa postura de oposição às exigências do discurso da Ciência que obriguem os profissionais a fazer provas experimentais acerca da eficácia do tratamento (Forbes, 1990). Porém, quando o ponto em foco deixa de ser a comprovação de eficácia, para passar a tratar do risco de que o tratamento possa fazer mal ou causar danos ao paciente, tem uma questão à qual a psicanálise não pode se furtar de enfrentar, ou seja, a questão da responsabilidade que o analista assume ao aceitar dar início a um processo de análise com um paciente. Faz-se necessário o debate aberto acerca dos possíveis riscos iatrogênicos do tratamento psicanalítico e quais as possíveis medidas para que o os riscos de ocorrência desses efeitos sejam reduzidos.

\section{JUSTIFICATIVA}

Desde sua origem com Freud, e até os dias atuais, a psicanálise, enquanto uma prática clínica teve que buscar modos de se posicionar em sua relação com a ciência. Sabemos que, de início, Freud trabalhou decididamente para que a psicanálise fosse reconhecida como uma ciência natural, em sua relação com aspectos biológicos do corpo humano. Assim, apesar de reconhecer que a Psicanálise, por conta das 
particularidades de seu objeto de estudo, estaria sujeita a certas particularidades ou especificidades de método, Freud sustentava o posicionamento de que a psicanálise deveria ser enquadrada como uma ciência (Freud, 1895/1996). Assim de início, havia o esforço para situar a psicanálise no âmbito científico de sua época, supondo-se a também a existência de uma etiologia física, química e biológica para os transtornos psíquicos. Importante destacar também como, já nesse momento, se configurava certo efeito de resistência ao discurso psicanalítico, por parte de outros campos do saber, seja no sentido de deslegitimá-la como prática legítima, seja no sentido de se apoderar da psicanálise restringindo seu uso e reduzindo-a a uma prática exclusivamente médica.

No embate entre Ciência e Psicanálise, desde Freud, já se mostrava também a aliança do discurso da ciência com outras áreas do saber, como, por exemplo, o discurso jurídico, utilizado como tentativa de subjugar a Psicanálise. É esse o contexto em que Freud redige o texto A Questão da Análise Leiga (1926/1996), em defesa de uma psicanálise livre dos entraves ou anseios de dominação impostos seja pelo discurso médico, seja pelo discurso jurídico.

Mas se Freud tinha essa intenção de situar a Psicanálise no campo da ciência, por outro lado não se pode negar a grande mudança epistemológica que ocorre com o surgimento da psicanálise, fundando um novo campo de saber, com sua própria especificidade quanto ao método e ao modo de investigação, subvertendo a própria lógica científica da época e colocando em cheque as possibilidades de apreensão do objeto pelo sujeito.

Assim, logo de partida temos uma questão que situa a psicanálise de modo diverso de outras ciências, ao afirmar que, para a psicanálise, investigação e tratamento andam juntos, ocorrem de modo simultâneo. Freud (1912b/1996, pg. 152) mesmo afirma que "A psicanálise faz em seu favor a reivindicação de que, em sua execução, tratamento e investigação coincidem”. Dessa novidade do método psicanalítico, pode-se extrair uma consequência para o modo como a psicanálise propõe a apreensão de seu objeto de investigação. Ora, se na psicanálise prática e pesquisa aparecem sempre interligadas, tem-se uma necessidade de constante revisão e questionamento acerca do que é possível extrair como conhecimento, a partir do objeto de investigação. 
Esta mudança no modo de investigação traz consigo efeitos para a própria construção de conhecimentos e de conceitos no campo psicanalítico, na passagem de uma posição científica, biológica, pautada em relações de causa e efeito e orientada por um ideal de objetividade, para a possibilidade de um novo modo de apreensão dos fenômenos, a partir de sua dimensão histórica, cultural, conjuntural, dotada de significações e compreensões variadas. Mais do que isso, das questões relativas ao objeto de investigação, decorrem também implicações relativas a aspectos pessoais e singulares do próprio investigador, ou seja, coloca-se em cheque a própria possibilidade de uma observação e investigação absolutamente neutra e imparcial. Ao inaugurar o estudo do inconsciente, Freud questiona a própria possibilidade de que a linguagem possa apreender de modo inequívoco os fenômenos que se apresentam. O efeito disso é a nova compreensão de indivíduo, enquanto sujeito dividido, a partir de sua relação com o inconsciente e com a linguagem. Tal virada decorrente do ensino freudiano seria chamada por Foucault de uma "reviravolta da psicologia" (Foucault, 1999), com efeitos irreversíveis também para o campo da filosofia e da epistemologia.

Ao longo da história da psicanálise, esse conflito com o discurso científico se perpetuou. Neste sentido, Lacan foi um dos defensores de uma posição de resistência, opondo a psicanálise ao discurso científico, realizando uma virada ao situar o próprio sujeito no centro desse embate entre ciência e psicanálise, "ao observar que o sujeito está em uma relação com o objeto no campo mesmo em que se constitui como sujeito" (Alberti \& Elia, 2008, pg. 780).

Contudo, apesar desses avanços na teoria psicanalítica, sabemos que, até os dias atuais, o embate com o discurso científico se mantém. Inclusive, o discurso científico, atrelado ao avanço do discurso capitalista, cada vez mais ganha força e legitimação, a partir de seu discurso científico, pautado em pesquisas experimentais. Como já ocorria desde a época de Freud, esse discurso científico se articula a outros discursos, em especial o discurso jurídico, no esforço para subjugar ou deslegitimar a prática psicanalítica. Recentemente, esse tema tem retornado com força, levantando intensos debates no cenário internacional e também no contexto brasileiro. Tais debates são resultantes justamente desse mutualismo entre discurso científico e discurso jurídico, 
resultando em tentativas de definir por vias jurídicas quais seriam os tratamentos permitidos ou aceitos no campo da saúde mental.

No cenário brasileiro, por exemplo, podemos destacar as tentativas de restringir e determinar quais seriam os modos de tratamento que devem ou não ser empregados nos serviços públicos de saúde mental em casos como o de tratamento de crianças autistas (Hans, 2012; Kupfer in Dunker, 2013). O argumento é de que apenas práticas clínicas pautadas em bases teóricas comprovadas cientifica e experimentalmente estariam legitimadas para atuar no campo da saúde mental.

Além dos efeitos de oposição ao campo da psicanálise, esta aliança entre discurso jurídico e discurso científico faz surgir também efeitos no interior do campo psicanalítico, com tentativas de certos grupos de buscar juridicamente a regulamentação da prática psicanalítica, restringindo seu ensino e aplicação aos grupos que adotam certos padrões de formação de analistas. No cenário brasileiro, podemos destacar as tentativas recentes de grupos como o da Sociedade Psicanalítica Ortodoxa do Brasil, instituição evangélica que promove ensino da psicanálise articulado à religião e que solicitou a promulgação de leis visando à regulamentação da psicanálise, buscando estabelecer o domínio e monopólio sobre esta prática apenas para aqueles a quem fosse concedido título de psicanalistas, em conformidade com os preceitos dessa instituição. Graças à organização e atuação de psicanalistas de diversas escolas de psicanálise do cenário nacional que juntas formaram o Grupo Articulação das Entidades Psicanalíticas Brasileiras, tais tentativas de regulamentação foram rechaçadas (Alberti et al., 2009). Mais recentemente, embates semelhantes surgiram diante da atuação da Associação Brasileira de Psicoterapia (ABRAP) (Sigal, 2007).

Trata-se assim de tentativas de restringir ou engessar a prática psicanalítica, a partir da pretensão de estabelecimento de normas, protocolos ou padrões de conduta e tratamento, ou regras de formação, que devam ser seguidos rigorosamente, sob pena de sansões por parte do Estado. Ou seja, criam-se padrões de tratamento ancorados num discurso científico (muitas vezes incompatível com a prática psicanalítica) e busca-se sua aplicação e legitimação a partir de instrumentos jurídicos, visando forçar a aplicação desses protocolos também aos psicanalistas. 
Ainda que tais momentos de embate tenham ocorrido de modo esporádico na história da psicanálise no contexto brasileiro, de modo geral esta relação de tensão entre Direito e Psicanálise parecia ter encontrado algum equilíbrio em certo modo de auto regulação, no âmbito dos consultórios particulares e das escolas de psicanálise, sem necessidade de intervenções por parte do Estado. Porém, como visto o cenário tem se alterado, sendo mais frequentes os conflitos entre os dois campos. Mudanças recentes no país como a maior presença de psicanalista atuando fora de seus consultórios, por exemplo, em instituições de saúde, fóruns, escolas, bem como o avanço dos anseios fiscalizatórios e regulatórios, movidos por demandas de comprovação científica de eficácia e resultados dos tratamentos, podem ser indicados como fatores que colaboram para aumento das tentativas de regulamentação ou restrição da prática psicanalítica.

Ao entrar numa instituição, o analista estaria sujeito a certas regras e procedimentos da instituição e, ao mesmo tempo, exposto à atenção e físcalização por parte de outros profissionais, administradores, fiscais de órgãos públicos e, em última instância, do sistema jurídico como um todo, com sua série de normas para a vida em sociedade. Não que o psicanalista em seu consultório esteja fora do alcance desses mecanismos, porém, ao se inserir numa instituição e se propor ao trabalho em conjunto com outros profissionais, para bem ou para mal, há um aumento de fiscalização e questionamentos sobre o trabalho do psicanalista, questionamentos que o afetam, havendo necessidade constante de repensar e reafirmar sua prática, sua ética, sua proposta de trabalho e suas possibilidades, não mais apenas ante o paciente com quem se estabelece um contrato, mas também para terceiros.

Em paralelo à crescente presença do analista nas instituições, outros processos colaboram para uma tendência no aumento de intervenções jurídicas sobre o campo psicanalítico. Os tribunais brasileiros têm sofrido com um enorme aumento no número de ações impetradas com temas de Direito do Consumidor, amparados pelas garantias legais do Código de Defesa do Consumidor. Dentre esses processos estão inclusos os processos por erro médico contra profissionais da área da saúde, por erros ou falhas cometidos no atendimento ao paciente, processos estes que também têm aumentado em número, colocando profissionais da área de saúde em evidência, tendo que responder 
judicialmente pela qualidade dos serviços prestados. O advento dos Juizados Especiais Cíveis, que permitem ao interessado mover uma ação judicial sem precisar de acompanhamento de um advogado, facilitam o acesso ao Judiciário, mas, em contrapartida, aumentam o número de ações e demandas.

Cumpre destacar que em casos como esse incide a garantia jurídica da inversão do ônus da prova, ou seja, excepcionalmente nesses casos, não é aquele que acusa quem deve fazer prova do que alega, mas sim o acusado que deve fazer prova de sua inocência. Em outras palavras, num eventual processo contra um psicanalista, caberia ao psicanalista caberia ao próprio psicanalista fazer provas de que o tratamento oferecido transcorreu de modo adequado. É fácil perceber o quão problemática tal situação pode se mostrar.

A confluência desses fatores permite vislumbrar um futuro próximo de embate entre Direito e Psicanálise, com demandas levadas aos tribunais por pacientes e tendo como mérito da causa a qualidade do trabalho realizado pelo psicanalista, cenário que já vem ocorrendo em países como Estados Unidos e Inglaterra. Em especial, casos de suicídio e erro diagnóstico têm sido mais frequentes dentre os processos contra profissionais da saúde mental nas instituições de saúde. Além da qualidade dos serviços prestados, a questão da regulamentação da profissão também é um aspecto que ganha força e que pode representar mais uma causa de confronto entre os campos do Direito e da Psicanálise. Processos por exercício ilegal da profissão também estão entre os casos mais comuns de processos movidos.

O resultado desse cenário pode ser visto em números. Em um levantamento conduzido pela Kaiser Family Foundation ${ }^{1}$, nos Estados Unidos, apenas no ano de 2010, foi registrado um total de 9.894 processos por malpractice. As indenizações envolvidas alcançam o valor de mais de 3,3 bilhões de dólares (MD News, 2012). Em outro estudo (Jena, 2011) publicado no The New England Journal of Medicine, os números indicam que, a cada ano, $7,4 \%$ de todos os médicos americanos são processados. Os dados mostram que cerca de $16 \%$ dos processos foram direcionados a

\footnotetext{
${ }^{1}$ Disponível em http://kff.org/
} 
profissionais de cuidado primário, sendo que $46 \%$ dos processos envolviam erros de diagnóstico.

Um cenário que poderia ser encarado como vantajoso, com uma maior organização e regulação da profissão, com o objetivo de proteger o paciente e lhe garantir o melhor atendimento possível mostra, na verdade, um problema resultante do descompasso entre a lógica legal e a lógica de algumas áreas da saúde, dentre elas a Psicanálise. O que era tido como uma tentativa de melhorar a qualidade dos serviços prestados acabou por se transformar em um excesso de regulamentações que acaba por limitar a atuação do psicanalista, com a incidência das normas e legislações que, em última instância, tendem a tornar a prática psicanalítica engessada, inviável ou até mesmo ilegal, impossibilitando seu exercício ao estipular padrões fixos de tratamento, muitas vezes pautados em medicação e critérios psiquiátricos, incompatíveis com a lógica psicanalítica. Nas palavras de Marvin Hyman (2001):

"Não, eu não estou prevendo que a psicanálise será proibida como ocorreu com o álcool no começo do século. Diferentemente, parece que ela será estrangulada até a morte por essa pletora de restrições e controles às quais se espera que a psicanálise se submeta, sendo tal conformidade forçada por meio de mecanismos jurídicos criminais ou civis, com estabelecimento de punições para aqueles que não cumprirem as regras estabelecidas."

A situação é tão grave que algumas instituições e organizações psicanalíticas, como a Academy for the Study of the Psychoanalytic Arts, uma divisão da Michigan Society for Psychoanalytic Psychology da divisão 39 da American Psychological Association (APA), chegou a propor que a Psicanálise se afaste da definição de uma especialidade de saúde, passando a se definir como profissão independente, fora do sistema de saúde (healthcare), como caminho possível para escapar dos excessos de regulações impostos a esses serviços e por não mais acreditarem na possibilidade de um caminho de diálogo em que se possa sustentar a prática psicanalítica diante do rigor dos discursos jurídico e científico. 
Voltando ao contexto brasileiro, o cenário indica que, ao menos em alguns aspectos, a mesma lógica de controle sobre os tratamentos de saúde começa a se propagar. Porém, ainda estamos no começo desse processo de encontro, entre a lógica psicanalítica e a lógica jurídica, sendo possíveis ainda intervenções e soluções que evitem um resultado tão adverso como o que ocorre nos Estados Unidos.

Como visto, com a criação da Psicanálise há, desde o início, um rompimento com o domínio da medicina, fundando-se uma nova área do saber, com suas características específicas, independente e com a proposta de uma prática voltada para o sujeito, em sua singularidade, sendo possível o trabalho do inconsciente, a partir da regra fundamental estabelecida por Freud: a regra da associação livre.

Apesar dessa especificidade e independência, é possível para o analista se inserir e adequar sua prática para atuação fora do setting analítico tradicional, adentrando o espaço de instituições como hospitais, escolas, tribunais, dentre outros é uma questão que se apresenta como fonte de novos desafios para a teoria e prática psicanalíticas. Sobre esse processo, Caffé (2006, pg. 36) afirma:

\footnotetext{
"Por razões de sobrevivência institucional (dentre elas, as razões de mercado) e em função das possibilidades abertas pelo seu próprio objeto - o inconsciente - a psicanálise tem se oferecido e tem sido chamada a colaborar em espaços sociais diversos e de diferentes maneiras. Podemos considerar aqui, por exemplo, os casos em que ela se transfere para as escolas, os hospitais, as instâncias jurídicas, dialogando, assim, com outras áreas do conhecimento humano, como a educação, a medicina e o direito."
}

Sobre esse processo de entrada do analista na instituição e suas possibilidades de atuação, podem-se destacar os trabalhos de Moretto (2013), sobre a prática da psicanálise no hospital e de Caffé (2006), sobre a atuação do psicanalista nos fóruns de justiça, ambos apresentando as particularidades e possibilidades de se construir uma prática clínica no interior da instituição e no contato com profissionais de outros ramos do saber, permitindo que a psicanálise possa expandir seu alcance, cada vez mais ampliando seu contato com a sociedade. 
Tais exemplos de participação e atuação do psicanalista junto a profissionais de outras áreas do saber permitem retomar o texto de Laurent (1996), O analista Cidadão, em que é feito um apelo aos psicanalistas justamente para que saiam de uma posição passiva, da reserva de seus consultórios particulares, para poderem se inserir e participar dos debates atuais que atravessam a vida em comunidade, podendo assumir a responsabilidade pela Psicanálise e para poder alcançar com sua prática os próprios mecanismos institucionais e sociais que ditam os rumos da sociedade. Em termos gerais, a possibilidade de inserção do analista no debate democrático, capaz de influenciar e promover mudanças sociais. Neste sentido, Laurent (1999, pg. 08) afirma:

"Os analistas têm que passar da posição de analista como especialista da desidentificação à de analista cidadão. Um analista cidadão no sentido que tem esse termo na teoria moderna da democracia. Os analistas precisam entender que há uma comunidade de interesses entre o discurso analítico e a democracia, mas entende-lo de verdade! Há que se passar do analista fechado em sua reserva, crítico, a um analista que participa; um analista sensível às formas de segregação; um analista capaz de entender qual foi sua função e qual lhe corresponde agora."

Indo além, Laurent afirma que é preciso que os analistas participem ativamente, tomando partido e realizando intervenções no debate democrático, sendo eles próprios os únicos capazes de fazer com que a prática psicanalítica seja ouvida. Assim, o analista cidadão seria aquele que "é a favor da existência de um lobby que intervenha no debate democrático. Deve transformar-se em um lobby e isso não é desgraça.” (Laurent, 1999, pg. 11).

Mais do que uma indicação ou sugestão, Laurent coloca essa atuação do psicanalista como um verdadeiro dever, o dever de assumir a responsabilidade pela psicanálise e levá-la ao seu máximo alcance, a fim de fortalecer o debate democrático e visando as melhores soluções para os problemas que se apresentam.

Para tanto, porém, faz-se necessária uma atuação do psicanalista no campo da tomada das decisões, participando do processo de busca de soluções práticas para os 
conflitos que se apresentam, desde níveis mais restritos como em uma interconsulta hospitalar ou na emissão de um parecer jurídico enviado a um juiz, até os níveis mais amplos, com a participação do psicanalista, por exemplo, na própria elaboração de políticas públicas nas áreas de saúde ou educação.

Desse modo, essa ampla participação no debate democrático passa, necessariamente, pela possibilidade de contato com outras áreas do saber, seja no embate e enfrentamento, a fim de fazer valer sua voz e sua prática, seja pela possibilidade de um trabalho conjunto, conferindo maior porosidade e construção conjunta entre psicanálise e outras áreas. Como afirma Laurent (1996), não se trata de temer as exigências do discurso científico ou discursos do mestre. Mas tampouco devese ignorar esses questionamentos. Trata-se, em verdade, da possibilidade de apresentar a prática psicanalítica de modo seguro, ancorada em seus fundamentos, mantendo suas especificidades e sustentando sua prática, mesmo diante dessas demandas. Nesse sentido, Caffé (2006, pg. 37) coloca:

"O caso é que estas operações requerem da psicanálise tanto firmeza em relação à especificidade do seu método, quanto capacidade de se deixar modificar, alterar e mesmo distorcer. E para isto não basta boa vontade. É necessário desenvolvermos recursos conceituais que, atendendo à singularidade do nosso campo, possam permitir um grau de porosidade maior, tendo em vista a interlocução mais ampla junto de outras práticas que nos são estranhas."

A questão que surge, porém, é de como realizar essa inserção no debate democrático de modo bem sucedido. Caffé aponta o caminho da reelaboração de recursos conceituais internos à psicanálise que possam permitir esse diálogo. Mas, retornando ao tema do trabalho, quais seriam as estratégias ou táticas capazes de conduzir essa reelaboração de recursos conceituais que possa ser sustentada ante esse discurso jurídico e científico?

Mesmo diante desses desafios há ainda entre os psicanalistas uma postura de oposição e resistência ante as exigências do discurso da Ciência que obriguem os 
profissionais a fazer provas experimentais acerca da eficácia do tratamento ou, no escopo desse trabalho, dos potenciais riscos envolvidos no tratamento (Forbes, 1990). Mas, se como vimos, não se trata de responder a essas demandas de comprovação de eficácia, tampouco trata-se de ignorá-las. Nesse sentido, o desafio que se coloca é de pensar em que medida é possível elaborar um saber que responda à questão acerca dos potenciais riscos iatrogênicos da psicanálise, mas ainda se mantendo fiel aos preceitos, fundamentos e particularidades do campo psicanalítico.

\section{OBJETivo}

O presente trabalho tem como objetivo fazer uma revisão sistemática da literatura sobre o tema do potencial iatrogênico da Psicanálise, de tal modo que a revisão proposta sirva de base para a posterior elaboração de um esquema teórico conceitual que amplie a discussão sobre o tema do potencial iatrogênico da psicanálise, visando, em última instância, compreender as possibilidades de redução de danos decorrentes do tratamento psicanalítico.

\section{MÉTODO}

Trata-se de uma pesquisa teórica, cujo método adotado é o da revisão sistemática da bibliografia pertinente ao tema da iatrogenia na Psicanálise, a fim de realizar o levantamento e análise do material que já há na literatura sobre este tema e sobre o problema de pesquisa escolhido. O objetivo é de determinar o atual "estado da arte", ou seja, demonstrar por meio da literatura já publicada o que é que já se sabe sobre o tema, quais as lacunas existentes e onde se encontram os principais entraves teóricos ou metodológicos a serem resolvidos.

Com o início da revisão bibliográfica, constatou-se que são raros os textos que abordem especificamente a questão da iatrogenia no campo da Psicanálise. Diante disso, 
a busca foi ampliada para recolher também elementos de outras áreas do saber como Farmacêutica, Direito, Medicina e Psicologia. A busca foi ampliada para incluir também outros termos de pesquisa correlatos, como "efeitos adversos" e "efeitos colaterais". Foi também realizada a busca dos termos em inglês, de modo que a maior parte dos resultados são de literatura estrangeira, particularmente norte-americana e britânica, onde a pesquisa sobre o tema se mostra mais presente.

Foram realizadas pesquisas em catálogos virtuais para busca também de livros e teses relacionados com o tema, bem como a pesquisa em bases de dados, nacionais e internacionais, para o levantamento de artigos científicos publicados e periódicos. No campo da Psicanálise foram privilegiados também textos de S. Freud, de J. Lacan e outros analistas de orientação lacaniana.

O material recolhido foi lido, fichado e analisado, de modo que os resultados da revisão possam ser apresentados neste trabalho. 


\title{
CAPÍtulo 1 - O Potencial IATROGÊNiCo dOS \\ TRATAMENTOS
}

Acerca da importância do médico no curso de um tratamento Balint (1957, pg. 198) escreve a célebre frase:

\begin{abstract}
"Em um desses seminários, o primeiro tópico discutido foram as drogas usualmente prescritas pelo médico. Muito rapidamente a discussão revelou - certamente não pela primeira vez na história da medicina - que de longe a droga mais usada na prática médica é o próprio médico. Não são apenas os remédios nos frascos ou as pílulas nas caixas que importam, mas o modo como o medico as ministra ao paciente - de fato, toda a atmosfera na qual a droga é prescrida e ingerida."
\end{abstract}

Contudo, Balint destaca também as dificuldades que essa constatação apresenta, vez que a "droga" médico não tem uma farmacologia clara, tampouco regras de dosagem, forma, frequência e, nem mesmo, uma descrição de potenciais efeitos colaterais ou adversos. Ainda que se possa acreditar que, com o tempo e a devida formação, o médico seja capaz de estabelecer certa noção acerca desses elementos, é evidente que a situação é muito diversa do que a que se verifica no uso de medicamentos.

Paira, então, o receio de que o trabalho do profissional de saúde possa também ser prejudicial ao paciente e, ao invés de promover sua cura e um reestabelecimento do bem estar, possa causar um agravamento do sofrimento ou perpetuação da doença. Balint (1957, pg. 688), então, alerta:

"Eu sei que essas ideias trazem uma pesada e alarmante responsabilidade para todos nós - clínicos gerais, especialistas, psicanalistas, e demais - mas eu acredito que possamos evitar enfrentar isso. E eu firmemente acredito que, ao nos tornar mais e mais advertidos de nossos papéis na relação entre medico e 
paciente - ou seja, nós como drogas passíveis de causar efeitos colaterais - nossa eficiência terapêutica irá prosperar."

Balint destaca, então, a importância de que, cada vez mais, se possa considerar uma maior gama de variáveis envolvidas na relação médico-paciente, em especial os eventuais efeitos adversos, sendo esse o caminho para a melhora na eficácia e sucesso terapêutico dos tratamentos. Acima de tudo, espera que os profissionais possam tomar consciência dos próprios efeitos colaterais que podem causar aos pacientes.

Desde então, com o passar dos anos, a questão dos efeitos adversos avançou significativamente no campo da medicina. Com o desenvolvimento de técnicas médicas cada vez mais sofisticadas e também com os avanços no campo da Farmacologia, mostrou-se necessário um maior cuidado com o potencial danoso dos novos tratamentos e a importância de se buscar tratamentos que possam ser o menos invasivos possíveis para os pacientes. Neste sentido, é prática comum a existência de agências reguladoras responsáveis por testar os novos medicamentos e tratamentos e decidir quais devem (ou não) ser permitidos. O papel das agências reguladoras influi diretamente nos tratamentos oferecidos, sendo um elemento importante a se ter em mente nessa discussão. A proposta, ao menos em tese, é de se buscar ao máximo reduzir os potenciais efeitos adversos dos tratamentos prescritos aos pacientes.

Mesmo com os cuidados tomados atualmente, a iatrogenia representa ainda um problema sério no campo da saúde, ocorrendo com frequência no curso dos tratamentos médicos, colocando em risco e até mesmo levando à morte de muitos pacientes.

Em um estudo realizado em um hospital universitário norte-americano, no ano de 1981, resultados mostraram que até um terço das doenças diagnosticadas no hospital eram de causa iatrogênica. Dessas doenças, uma em cada 10 era considerada grave e em $2 \%$ dos casos, levou à morte (Steel et al., 1981). A maior parte dos casos era relacionada com os medicamentos indicados, ou seja, iatrogenia farmacológica, mas outras causas relevantes de iatrogenia foram a má avaliação de pacientes e os erros diagnósticos, bem como falta de acompanhamento e monitoramento adequados do quadro do paciente, que poderiam evitar os efeitos iatrogênicos. 
Em outros estudos realizados nos Estados Unidos (Leape, 1992; Phillips et al., 1998; Lazarou et al., 1988) números anteriores ao ano 2000 mostram as seguintes estatísticas de mortes por iatrogenia no país:

- 12 mil mortes em cirurgias desnecessárias

- 7 mil mortes por erros de medicação prescrita em hospitais

- 20 mil mortes por outros erros hospitalares

- 80 mil mortes por infecções hospitalares

- 106 mil mortes por efeitos colaterais dos medicamentos (não por erro de medicação prescrita)

Considerando estes números, pode-se considerar que iatrogenias são responsáveis por cerca de 225.000 mortes por ano, número que coloca a iatrogenia como terceira maior causa de morte nos Estados Unidos, abaixo apenas de doenças cardíacas e câncer, e muito acima da causa seguinte na lista que seria a doença cerebrovascular. Outros estudos conduzidos pelo Instituto de Medicina norte-americano mencionam números entre 230 mil e 284 mil (Starfield, 2000). E essas são estatísticas extraídas considerando apenas ambientes hospitalares, de modo que os números poderiam ser ainda maiores, se considerados pacientes que não estão internados. Além disso, tais estudos consideram apenas mortes, não incluindo outros possíveis efeitos negativos. Esses dados fornecem uma boa ilustração da magnitude do problema da iatrogenia nos serviços de saúde.

No âmbito da Farmacologia, a questão das iatrogenias tem recebido especial atenção, sendo muitos comuns - e até mesmo obrigatórias - pesquisas que verifiquem os efeitos adversos dos medicamentos. Novos medicamentos são submetidos a rigorosos testes que buscam verificar não apenas sua eficácia para o tratamento de uma determinada condição, mas também os potenciais efeitos adversos envolvidos no seu uso (Nutt \& Sharpe, 2008).

Também na Medicina, o assunto é objeto de atenção, especialmente em se tratando de procedimentos cirúrgicos ou invasivos, buscando-se sempre novas soluções que não apenas sejam eficazes para tratar o problema alvo, mas que também o façam 
com o menor grau possível de sofrimento e prejuízo ao paciente. Como já mencionado, desde Hipócrates, já se tinha ciência do potencial nocivo das intervenções médicas, sendo estabelecido como primeiro mandamento do Juramento Hipocrático o princípio de que não se faça mal ao paciente.

Contudo, no campo da saúde mental, mais particularmente dentre as psicoterapias, os avanços sobre o tema foram mais tardios, tanto em termos de comprovação cientifica da eficácia dos tratamentos como na investigação acerca dos possíveis efeitos iatrogênicos, não alcançando ainda o mesmo patamar constatado na Farmacologia ou mesmo na Medicina (Hansen et al., 2002).

No começo da década de 50, Eysenck (1952) afirmou que nenhum tipo de psicoterapia seria capaz de produzir qualquer tipo de efeito positivo para o paciente. A afirmação de Eysenck se pautava em uma revisão de 19 outros estudos empíricos realizados com diversas modalidades de psicoterapias, incluindo as de orientação psicanalítica, avaliando quais as taxas de melhoras para o paciente alcançadas por cada modalidade. No total, mais de 7000 casos de pacientes neuróticos foram avaliados, sendo que a única medida de sucesso ou fracasso do tratamento era o registro fornecido pelo próprio terapeuta em termos de quatro categorias possíveis: cura ou muita melhora; melhora; pouca melhora; e nenhuma melhora.

Os resultados alcançados por Eysenck mostraram que os tratamentos psicanalíticos alcançaram melhora de 66\%. Já os pacientes tratados com outras psicoterapias alcançaram melhora de $64 \%$, enquanto pacientes tratados de maneira mais geral por profissionais médicos, sem uso de psicoterapias, alcançaram melhoras de $72 \%$. Desse modo, os resultados alcançados pela psicanálise, pelas outras psicoterapias ou pelo simples tratamento sem psicoterapias seriam praticamente equivalentes. Diante dos resultados, Eysenck (1952, pg. 321) conclui que:

"De modo geral, certas conclusões são possíveis a partir desses dados. Eles falham em comprovar que psicoterapia, Freudiana ou outra qualquer, possam facilitar a recuperação de pacientes neuróticos. Dados mostram que aproximadamente dois terços de um grupo de pacientes neuróticos irão se recuperar ou melhorar até 
um certo ponto em um período de cerca de dois anos contados do começo do adoecimento, sejam eles tratados com psicoterapias ou não. Esse percentual parece ser surpreendentemente estável de uma pesquisa para outra, independentemente do tipo de paciente tratado, o padrão de recuperação aplicado ou o método de terapia usado. Do ponto de vista do neurótico, esses dados são encorajadores; mas do ponto de vista dos psicoterapeutas, as evidências dificilmente podem ser considerados a favor de seus argumentos."

As conclusões de Eysenck (1952) foram inquietantes e levaram a opiniões diversas entre os profissionais e pesquisadores da área. Alguns terapeutas ignoraram as implicações da publicação de Eysenck e continuaram defendendo que a prática da psicoterapia era importante, tomando a psicoterapia e sua eficácia como algo facilmente constatável, para o qual não seriam necessárias maiores investigações. Continuavam a defender o papel vital das psicoterapias no âmbito da saúde mental, destacando sua clara eficácia no cotidiano das clínicas, sem maiores preocupações acerca da verificabilidade desses dados. Henry \& Strupp (1994, pg. 54) chegam a afirmar que:

\footnotetext{
"observações clínicas documentam amplamente que muitos pacientes se beneficiam de uma relação interpessoal com um profissional quando estão perturbados por dificuldades da vida e procuram ajuda. Argumentar o contrário é simplesmente fechar os olhos para os fatos"
}

Em resposta a esse grupo, Eysenck (1952), de maneira irônica, lembra que durante muito tempo todos também sabiam que a terra era plana...

Já outros, indo em sentido oposto, seguiram a posição apresentada por Eysenck, chegando a defender o fim das psicoterapias como um todo, vez que não haveria utilidade ou viabilidade de se dar continuidade ao uso de tratamentos que não tinham provas científicas de sua eficácia no âmbito da saúde mental.

Contudo, o mais relevante efeito das conclusões apresentadas por Eysenck (1952) foi o início de uma insistente busca pela demonstração científica para a eficácia e validade do uso das psicoterapias (Barlow, 2009). Ao longo das décadas seguintes, 
diversos trabalhos de revisão foram realizados e os resultados, em geral, demonstravam haver sim uma alta eficácia de resultados para as psicoterapias, apesar de não serem capaz de localizar grandes diferenças ao comparar as diversas linhas de tratamento (Luborsky, Singer \& Luborsky, 1975; Smith, Glass \& Miller, 1980). Luborsky, Singer \& Luborsky (1975, pg. 997), revisando um total de 105 pesquisas que comparavam diversas práticas psicoterápicas, concluíram que:

"a maioria dos estudos comparativos das diferentes formas de psicoterapia revelaram diferenças insignificantes nas proporções de pacientes que melhoraram ao final da psicoterapia”

Smith et al. (1980), em outra revisão, consideraram um total de 475 estudos utilizando grupos-controle para testar os resultados das psicoterapias. Os resultados mostraram que a média dos indivíduos tratados teve melhoras $85 \%$ acima da média dos indivíduos do grupo controle, o que reforça a eficácia do uso de psicoterapias.

Contudo, para fins do presente trabalho, mais do que a discussão sobre a eficácia das psicoterapias ou a diferença de eficácia entre as diversas linhas teóricas, nos interessa os possíveis efeitos adversos causados pelo tratamento. Tal hipótese viria a ser mais bem explorada por Bergin (1966), em uma resposta aos resultados alcançados por Eysenck (1952). Bergin faz uma revisão dos mesmos trabalhos usados como base por Eysenck, mas com uma análise mais detalhada e minuciosa dos dados. A partir dessa revisão, Bergin (1966, pg. 235) extrai seis conclusões, das quais nos interessa em especial a primeira delas: "Psicoterapia pode fazer com que pessoas se tornem melhor ou pior ajustadas quando comparadas com pessoas que não receberam o tratamento.".

Assim, a conclusão alcançada por Bergin é de que as psicoterapias podem tanto trazer efeitos positivos, como também efeitos negativos para os pacientes. Resultados preliminares de estudos realizados com pacientes esquizofrênicos (Rogers, 1961; Truax, 1963; Carkhuff \& Truax, 1964) já pareciam indicar que os pacientes tratados com psicoterapia podiam ter melhoras ou pioras em seus níveis de ajustamento social, se comparados aos pacientes dos grupos controles. Outros estudos (Barron \& Leary, 1955; Cartwright, 1956; Cartwright \& Vogel, 1960; Fairweather et al., 1960; Mink, 1959; 
Powers \& Witmer, 1951; Rogers \& Dymond, 1954) também mostravam resultados semelhantes. Porém, em todos esses casos, tais resultados não eram a descoberta principal da pesquisa e, portanto não recebiam maior atenção (Bergin, 1963).

Interessante notar que os resultados indicavam, na média, que a variação na saúde dos pacientes era quase a mesma, tanto nos que foram tratados com psicoterapia quanto nos do grupo controle. Porém, a diferença identificada por Bergin estava na variabilidade de resultados. Os resultados de mudanças, dentre os pacientes submetidos ao tratamento, tiveram uma dispersão muito maior, com valores bem acima e também bem abaixo da média, enquanto que, dentre os pacientes do grupo controle, os resultados se mostraram mais concentrados, próximos à média dos resultados. A diferença residia na dispersão dos resultados, ainda que, na média, os efeitos fossem equivalentes.

Ou seja, considerando a média de resultados, seria possível sustentar a hipótese de Eysenck, de que as psicoterapias não operam efeitos significativos sobre os pacientes, afinal a média de resultados era equivalente entre os pacientes tratados e os pacientes do grupo controle. Contudo, uma análise mais minuciosa mostra que há diferenças entre os pacientes tratados com psicoterapia e os pacientes do grupo controle, sendo que os pacientes que passaram pelo tratamento demonstraram melhoras muito mais significativas que os do grupo controle, em alguns casos, mas também pioras muito mais significativas que os pacientes que não receberam tratamento, em outros casos.

Nas palavras de Bergin (1966, pg. 235):

"Agora frequentemente documentada, essa informação é alarmante, para dizer o mínimo. Psicoterapia pode e faz com que pacientes fiquem pior do que os mebros do grupo controle!"

Cartwright (1956, pg. 403), ao realizar uma reanálise do estudo de Barron \& Leary (1955) (um dos artigos analisados também por Bergin), afirma que: 
"Em muitas escalas, os resultados de variança entre os dois grupos estão ausentes devido a diferenças de dois tipos, opostas em valência, estão presentes. Parece que alguns pacientes submetidos a terapia pioraram mais do que os que ficaram no grupo controle, enquanto que alguns pacientes de terapia de fato melhoraram significativamente mais do que os membros do grupo controle."

E Bergin (1966, pg. 237), em resposta a Eysenck:

"Felizmente, esses diversos dados indicam que psicoterapia pode produzir melhoras significativas para pacientes, se comparados aos pacientes do grupo controle. Desse modo, contrário ao que sustentam alguns críticos, psicoterapias podem produzir melhoras para além do que é produzido apenas pela remissão espontânea. Consistentemente replicados, esse é uma direta e inequívoca refutação da antes-citada posição (Eysenck, 1960, 1965)"

Para representar tais resultados, Bergin (1966) propõe a representação gráfica abaixo e sugere a utilização do termo "Deterioration Effect":

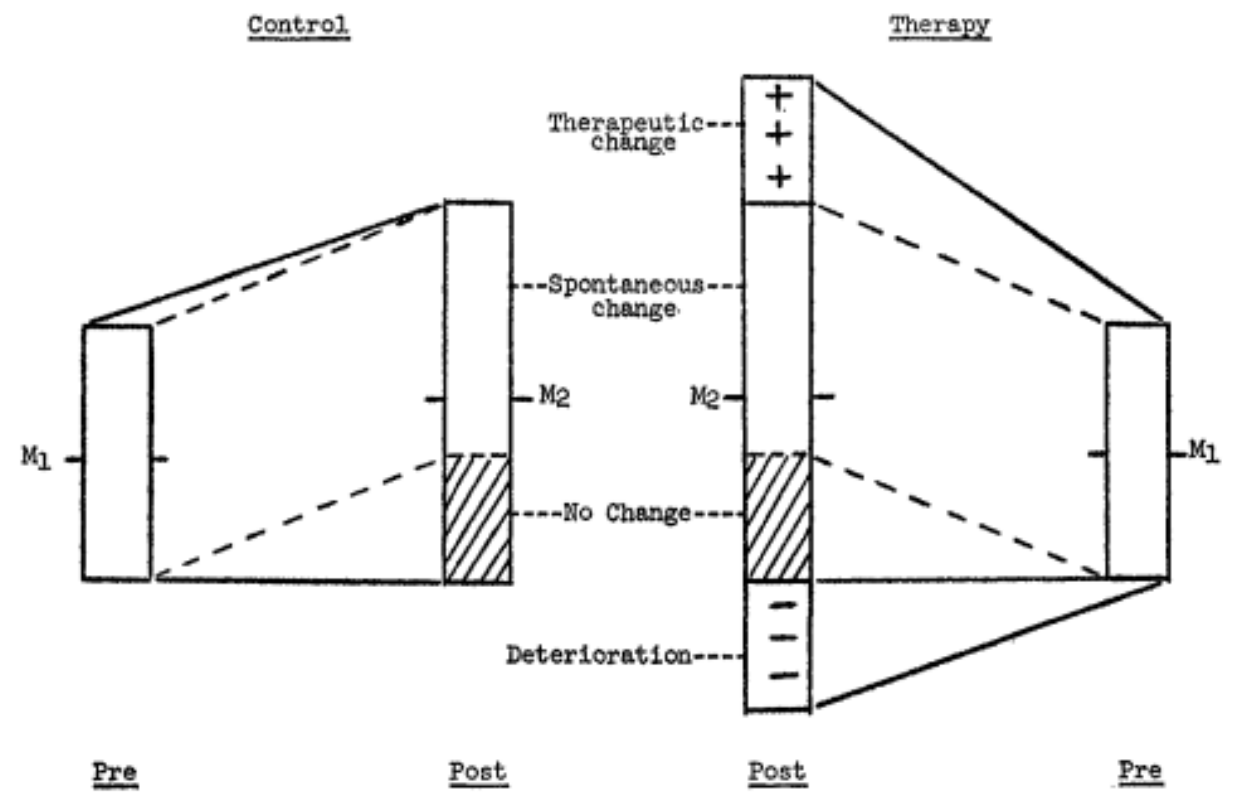

Figura 1: Representação gráfica do Deterioration Effect (Bergin, 1966, pg. 238) 
A partir do conceito de Deterioration Effect, Bergin extrai então três implicações relevantes para o campo das psicoterapias. Em primeiro lugar, o fato de que não se deve abandonar o uso das psicoterapias, como alguns defendiam, pois os estudos demonstraram que o método é capaz de produzir melhores significativas para o paciente. O segundo ponto é a importância de que profissionais e pesquisadores se engajem e dediquem mais para pesquisar a possibilidade de efeitos adversos de seus tratamentos. A terceira implicação é a importância de se confirmar, no nível individual, se existem terapeutas que só causam melhoras e outros que só causam mal, ou se um mesmo terapeuta é capaz de causar as duas coisas. Tendo essas respostas, será possível ajustar a prática e a técnica psicoterápica de modo a diminuir os efeitos adversos e acentuar os efeitos positivos.

Contudo, apesar do avanço nas tentativas de comprovação científica dos efeitos das psicoterapias, no geral maior ênfase tem sido dada apenas à comprovação de eficácia de aspectos positivos dos tratamentos, sendo os efeitos adversos pouco abordados. Lambert, Bergin \& Collins (1977) afirmam que a ideia de que uma psicoterapia possa causar prejuízos tem sido historicamente, recebida com inércia e oposição. Boisvert \& Faust (2007) apontam também que psicoterapeutas tendem a subestimar a ocorrência dos efeitos negativos de seus tratamentos. Já para Crown (1983), os psicoterapeutas que tentam abordar esse tema são vistos pelos colegas com certa desconfiança, como profissionais que possuem dúvidas acerca da prática que exercem, o que seria outro motivo que desestimula as pesquisas sobre o tema.

Neste sentido, Berk \& Parker (2009, pg. 787):

"qualquer intervenção potente tem tanto a capacidade de curar quanto de causar danos. Para testes com terapias baseadas em medicação, o monitoramente de efeitos adversos é obrigatório. Em contraste, a avaliação das psicoterapias tem historicamente privilegiado apenas o lado benéfico da equação."

Ou, ainda (Berk \& Parker, 2009, pg. 793): 
"psicoterapias são uma base de eficácia da prática atual. A própria potencia de tais terapias dá origem a riscos que podem não ter sido devidamente apreciados, e, portanto, há uma presunção tácita pelos profissionais e pacientes de que a psicoterapia é amplamente livre de riscos. Isso pode ser um grande engano. "

Castonguay et al. (2010, pg. 34) também destaca a importância de que os terapeutas possam, por mais doloroso que seja, reconhecer que é muito provável que todos tenham, em algum ponto de suas carreiras, causado danos a um ou mais pacientes:

"nos arriscamos a presumir que todos psicoterapeutas com alguma experiência, em um ponto ou outro de suas carreiras, já falharam em cumprir o mais básico e eticamente importante princípio que guia a profissão: primeiramente, não causar mal ao paciente (American Psychological Association, 2002). Considerando o desafio e a complexidade dos problemas clínicos envolvidos no processo terapêutico, que psicoterapeutas cometam erros isolados na estratégia clínica e/ou uma falta momentânea de cuidado com as necessidades do paciente são inevitáveis."

Berk \& Parker (2009) levantam a questão sobre por que o lado negativo do tratamento tem sido negligenciado. Um dos aspectos destacados pelos autores é a existência de certa crença entre os profissionais de que um terapeuta ruim, ineficaz ou explorador, naturalmente perderia todos seus pacientes com o passar do tempo, pararia de receber indicações e, aos poucos seria excluído de sua atividade, vez que os pacientes se recusariam a retornar a um profissional inadequado, reduzindo a possibilidade de ocorrência de algum efeito adverso. Uma espécie de "seleção natural" dentre os profissionais em atividade.

Contudo, segundo os autores, isso não é o que mostra a prática clínica. Há pacientes que mesmo em casos de tratamento ineficaz ou prejudicial optam por continuar o tratamento, seja por que aos poucos se adapta ao terapeuta abusivo, caso não ocorra nenhuma ofensa muito grave, e enquanto isso o quadro do paciente vai se deteriorando, seja por que o paciente não consegue identificar o tratamento como causador de sofrimento, vez que não tem o conhecimento teórico necessário para avaliar 
se um tratamento está sendo adequadamente conduzido ou não, tampouco se aquele tratamento é o mais indicado ou eficaz para suas necessidades. Além disso, muitas vezes as condições de adoecimento do paciente podem reduzir sua capacidade de avaliar o tratamento, como nos casos em que o paciente está sob efeito de medicação ou passando por momentos de grande confusão que prejudiquem seu julgamento. $O$ resultado pode ser uma dependência do paciente ao tratamento e ao terapeuta, com o paciente obtendo ganhos secundários com as sessões, enquanto sua condição se agrava.

Desse modo, a ideia de que terapeutas que causam dano seriam simplesmente eliminados do mercado gradativamente pode, na verdade, servir como base para mascarar a atividade de terapeutas que causam danos e que seguem a oferecer seus serviços, sem maiores preocupações.

Lambert, Bergin \& Collins (1977) fazem um levantamento de estudos que tentaram avaliar a questão dos efeitos adversos nas psicoterapias em geral. Alguns resultados afirmam que de 3\% a 10\% dos pacientes pioram após entrar na psicoterapia, com taxas de 7\% a 15\% no caso de pacientes com abuso de substâncias (Mohr, 1995; Moos, 2005; Boisvert \& Faust, 2007). Em outro artigo, a estimativa é de que aproximadamente 10\% das pessoas pioram após o início do tratamento (Jarret, 2007).

Já para Hansen, Lambert \& Forman (2002), utilizando testes clínicos randomizados, em que os tratamentos eram oferecidos por terapeutas supervisionados e cuidadosamente selecionados, e tratando apenas de pacientes já diagnosticados previamente com alguma doença específica, cerca de $35 \%$ a $40 \%$ dos pacientes não obtiveram nenhum benefício com a psicoterapia e uma pequena parcela dos pacientes, entre $5 \%$ e $10 \%$ tiveram piora na sua condição. Lambert \& Ogles (2004), afirmam que aproximadamente $5 \%$ a $10 \%$ dos pacientes sofrem pioras no curso do tratamento. Os números podem chegar a até $10 \%$ a $15 \%$ no caso de pacientes com problemas de abuso de substâncias (Lilienfeld, 2007). Outros estudos de importância também demonstraram os efeitos negativos de diversas modalidades de abordagens psicoterapêuticas em diversas populações clínicas (Foa \& Emmelkamp, 1983; Mays \& Franks, 1985; Strupp, Hadley \& Gomez-Schwartz, 1977). 
Strupp \& Hadley (1976) realizaram uma pesquisa consultando 150 psicoterapeutas acerca da existência e natureza dos efeitos adversos. Setenta desses profissionais responderam, sendo eles de orientações teóricas variadas, como behavioristas, psicodinâmicos e fenomenológicos, e os resultados mostraram que 3\% a $6 \%$ dos pacientes tiveram pioras.

\section{Segundo Crown (1983, pg. 436):}

"Todo tratamento, de aspirinas a esteróides e de psicotrópicos a psicotóxicos, se são eficazes, inevitavelmente terá efeitos tanto curativos quanto adversos. Nesse sentido, psicoterapia não é diferente de outros tratamentos de saúde. Seus efeitos adversos devem ser reconhecidos, suas fontes investigadas e explicitadas e estratégias sugeridas para como evitar ou reduzir tais efeitos."

Assim, se reconhecemos que todo o tratamento, inclusive tratamentos psicoterapêuticos ou psicanalíticos, tem o poder para curar um paciente, é forçoso reconhecer também que esses tratamentos detém um potencial iatrogênico, oferecendo riscos ao paciente que pode ter seu quadro agravado após passar pelo tratamento. Cumpre então aprofundar a investigação sobre o potencial iatrogênicos destes tratamentos. Porém, como será demonstrado no capítulo seguinte, a pesquisa sobre o tema tem avançado timidamente e enfrente ainda uma série de obstáculos metodológicos. 


\section{CApítulo 2 - Dificuldades Metodológicas Para PESQUISA SOBRE POTENCIAL IATROGÊNICO DOS}

TRATAMENTOS

Apesar da constatação acerca da possibilidade de ocorrência de efeitos iatrogênicos no curso do tratamento e dos alertas para a importância da pesquisa sobre o tema, conduzir uma investigação neste campo é tarefa árdua, vez que a pesquisa nesse campo enfrenta uma série de obstáculos metodológicos. Isso porque ao buscar investigar se um tratamento causou prejuízos a um paciente não se trata apenas de aferir quais pacientes pioraram após o início do tratamento, mas sim de se criar um mecanismo de análise que permita identificar também se os efeitos adversos observados foram ou não causados pelo tratamento.

Nesse sentido, por exemplo, um paciente que apresenta piora no curso de um tratamento talvez pudesse ter piorado ainda mais caso não houvesse recebido o tratamento, de modo que o tratamento, na verdade, teria sido positivo, ao reduzir o grau de deterioração do quadro do paciente. Outro exemplo são casos em que uma piora no quadro do paciente é constatada, mas tal piora é, na verdade, decorrente de fatores completamente alheios ao tratamento (como, por exemplo, a morte de um familiar ou outro evento adverso na vida pessoal do paciente). No sentido oposto, um paciente que apresenta melhoras não necessariamente foi beneficiado pelo tratamento. Talvez o paciente já tivesse uma tendência a melhorar e o tratamento na verdade retardou ou dificultou sua recuperação, ou simplesmente não teve impacto nenhum no curso de seu processo de cura.

Assim, a análise acerca dos efeitos negativos é complexa e multifatorial, sendo necessários grandes esforços na busca de uma metodologia capaz de contemplar esse tipo de investigação. Apesar das dificuldades da pesquisa sobre efeitos negativos das psicoterapias, Lambert \& Ogles (2004, pg. 189) afirmam: 
"Apesar dos efeitos negativos serem difíceis, se não imposíveis, de serem estudos num ambiente experimental controlado, as pesquisas claramente indicam que alguns pacientes estão piores no momento de encerramento da terapia do que estavam quando iniciaram."

Em outros estudos conduzidos por Lambert, coletando evidência de mais de 50 estudos (Bergin \& Lambert, 1978; Lambert, Bergin \& Collins, 1977), em busca de dados acerca da prevalência, incidência e magnitude dos efeitos adversos, Lambert destaca que o trabalho de coleta desses dados é muito árduo, sendo necessária a coleta de pequenas peças de informações espalhadas em diversas pesquisas para tentar delas extrair algum saber acerca dos efeitos iatrogênicos. Isso porque são poucos os estudos que abordam especificamente a questão dos efeitos adversos. Assim, ao realizar revisões na bibliografia sobre esse tema, é necessário certo trabalho interpretativo, para identificar quais dados indicam efeitos adversos no tratamento.

Lambert destaca também outra dificuldade no estudo do tema que é a grande resistência dos profissionais em tratar dessa questão, sendo que estudos mais antigos sequer consideravam a hipótese de deterioração no quadro do paciente ao estabelecer as categorias de avaliação do paciente numa pesquisa. Durante muito tempo, a possibilidade de efeitos adversos era simplesmente ignorada pelos pesquisadores.

Mas Lambert reconhece que, aos poucos, avanços foram feitos nesse tema, sendo possível notar um aumento no rigor e na precisão das investigações realizadas, o que tem, como consequência, resultado também em aumento da qualidade das terapias oferecidas, permitindo alcançar melhores resultados com os pacientes. Mas apesar dessa certa melhora, os resultados coletados mostram que os efeitos adversos ainda se mantém e numa taxa significativa. Mesmo para os pacientes que participam desses experimentos e que, portanto, são tratados em ambientes experimentais cuidadosamente controlados e preparados, eram verificados casos de piora no quadro dos pacientes. Mais do que isso, constatou-se que o número de pacientes do grupo controle que apresentavam efeitos adversos era menor do que dentre os pacientes que de fato receberam o tratamento, um dado que coloca um alerta sobre os riscos envolvidos no tratamento (Beutler et al., 
1984; Doherty, Lester \& Leigh, 1986; Emmelkamp, De Haan \& Hoodguin, 1990; Henry, Scracht \& Strupp, 1986).

No geral, os resultados das pesquisas com testes randomizados utilizando grupos controle demonstraram que cerca de dois terços dos pacientes adultos apresentam melhoras após 14 atendimentos, mas um terço dos pacientes não apresenta melhora ou até pioram (Hansen, Lambert \& Forman, 2002). Os mesmos autores investigaram resultados de mais de 6.000 pacientes do cotidiano em clínicas públicas e centro de saúde mental - portanto fora de um ambiente experimental controlado - e os resultados foram ainda mais alarmantes: cerca de apenas um terço dos pacientes apresentou melhora ou recuperação, mais de $50 \%$ não responderam ao tratamento e uma média de $8 \%$ pioraram (resultados variaram de $3 \%$ a $14 \%$ ).

Em estudos controlados realizados com pacientes crianças (Weiss et al., 1999; Weisz, Donenberg, Han \& Lauyneckis, 1995), os resultados foram mais preocupantes do que os constatados com adultos: a média dos resultados obtidos mostrou que os efeitos observados para o grupo que recebeu o tratamento foram praticamente os mesmos dos resultados para as crianças do grupo controle, ou seja, sem benefícios adicionais para aqueles que de fato receberam o tratamento. Warren et al. (2010), em um estudo com pacientes de instituições públicas de saúde mental, com mais de 4.000 pacientes crianças e adolescentes concluíram que as taxas de piora dentre os pacientes tratados era de pelo menos $14 \%$, podendo chegar a surpreendentes $24 \%$. Na ampla maioria, os estudos consideravam apenas técnicas psicoterápicas, em especial, as de orientação comportamental. Diante desses dados, Lambert \& Ogles (2004, pg. 192) afirmam:

"A literature sobre efeitos negativos sugerem que, ainda que os estudos tenham muitas limitações metodológicas e ambiguidades, a evidência de que psicoterapias podem e causam mal a uma porção dos pacientes que se propõe a ajudar é substancial. O fato de que uma porção relativamente consistente dos adultos (5\% a 10\%) e uma proporção surpreendentemente alta entre crianças $(14 \%$ a $24 \%$ ) pioram durante o curso do tratamento - especialmente em cuidado diário - carece de soluções. O estudo de efeitos adversos 
tem importantes implicações para a selação de alunos para pesquisas, a seleção de pacientes para o tratamento, a adequação de procedimentos ou métodos específicos para certos pacientes, e a seleção, treino e avaliação de terapeutas."

O estudo da variação negativa tem implicações importantes para a seleção de alunos para o estudo de pós-graduação, a seleção de clientes para o tratamento, a adequação de procedimentos específicos para alguns clientes, e a selecção, formação e acompanhamento de terapeutas

Assim, as pesquisas tem alcançado certo sucesso em obter evidências acerca da ocorrência dos efeitos adversos. Porém, ainda não alcançou maiores avanços em identificar quais seriam as causas ou aspectos envolvidos na ocorrência desses efeitos adversos, ou em propor mecanismos para redução desses índices.

Linden (2012), ao discutir as grandes dificuldades envolvidas no estudo dos efeitos adversos dos tratamentos psicoterapêuticos, toma como base os trabalhos de Dimidjian \& Hollon (2010) e Hatfield et al. (2010) para elaborar uma lista de sete motivos pelos quais a pesquisa sobre o tema se mostra tão difícil.

O primeiro ponto destacado por Linden é de que, ao se falar de efeitos adversos em psicoterapia, estamos lidando com uma dinâmica diversa daquela verificada na farmacêutica, argumento também sustentado por Nutt \& Sharpe (2008). Assim, enquanto na farmacêutica é possível fazer experimentos mais rigorosos e controlados, alterando doses das substâncias investigadas e avaliando as reações químicas e físicas envolvidas, para o tratamento psicoterapêutico isso não é tão simples, sendo difícil mensurar as variáveis envolvidas. Outra diferença é que, no caso da psicoterapia, o tratamento e seus eventuais efeitos são resultante direta da ação do terapeuta, que pode vir a ser responsabilizado - inclusive na esfera judicial - por um eventual resultado adverso do tratamento, o que pode resultar em uma maior resistência dos terapeutas em admitir ou reportar eventuais erros cometidos.

Como demonstra Levenson et al. (2010), psicoterapeutas tem dificuldade em prever o curso de um tratamento, bem como em identificar eventuais fracassos e pioras 
na condição do paciente, tendo uma tendência a crer que o tratamento oferecido está sendo positivo. Em especial quanto aos efeitos adversos, Eaton et al. (1993), destacam que há uma maior dificuldade do terapeuta em reconhecer tais efeitos, havendo uma tendência a desqualificar o reconhecimento de um efeito negativo, atribuindo-o a características ou comportamentos do próprio paciente mas não como efeito do tratamento. Assim, terapeutas, de modo geral, tendem a não perceber ou não reconhecer os efeitos adversos que causam.

O segundo aspecto destacado por Linden é de que, caso o terapeuta falhe em perceber o efeito adverso de um tratamento, vindo a tomar ciência do ocorrido apenas após o dano causando, há grandes chances de que o terapeuta acabe por ocultar deliberadamente tais resultados, a fim de evitar possíveis punições na esfera judicial, o que dificulta ainda mais a identificação de eventuais danos causados.

Um terceiro obstáculo é a difícil diferenciação entre o que seriam, de fato, efeitos ou danos causados pelo tratamento e o que seria apenas uma melhora ou piora decorrentes do curso natural de uma determinada doença, ou mesmo uma breve piora, inerente ao tratamento, mas que levará à melhora do paciente em um segundo momento.

Outro aspecto é que até mesmo as reações demonstradas pelo paciente podem, em certos casos, se mostrar difíceis de classificar como efeitos positivos ou negativos do tratamento. Uma mesma reação por parte do paciente pode ser positiva em uma situação, porém, negativa em outra como, por exemplo, o choro de um paciente ou um momento de silêncio.

O quinto problema é que, ainda que em graus variados, os tratamentos psicoterapêuticos tendem a estabelecer regras de procedimento e padrão no atendimento mais ou menos flexíveis, mas havendo sempre algum espaço para que o terapeuta faça alterações na condução do tratamento, conforme a necessidade de cada caso. Assim, sem uma maior clareza e estabilidade acerca do que configura um tratamento padrão ou um tratamento ideal, ainda que se identifique um eventual efeito adverso, é difícil perceber se ele seria resultado do próprio tratamento, conduzido de modo adequado pelo terapeuta ou se seria resultado de um erro por parte do profissional. 
Mais um obstáculo levantado por Linden e também já levantado por Nutt \& Sharpe (2008) é de que as pesquisas que são conduzidas sobre efeitos dos tratamentos psicoterapêuticos muitas vezes não chegam sequer a investigar a hipótese de ocorrência de efeitos adversos, o que reduz em muito a disponibilidade de dados sobre o tema.

Por fim, Linden destaca que, ainda que fosse possível reconhecer e mensurar os efeitos adversos, antes de mais nada seria necessário um sistema adequado de classificações e definições que permita orientar tal processo e elaborar comparações e, posteriormente, intervenções para diminuição dos riscos de efeitos adversos. Contudo, não há ainda nenhum consenso acerca desse sistema de definiçõos que permita definir, classificar e avaliar o que seriam os efeitos colaterais ao se pensar em um tratamento psicoterapêutico.

É bem verdade, porém, que esse último argumento acaba por recair numa certa tautologia, uma espécie de ciclo vicioso, sem solução: não se pesquisa por que não se tem bases classificatórias para orientar a pesquisa, mas não se tem bases classificatórias por que não se faz a pesquisa. De modo que algum primeiro passo precisa ser dado para que se saia desse impasse.

Mesmo ciente dessas dificuldades, Linden destaca a importância de se estar atento aos efeitos adversos pois, acima de tudo, como em qualquer outro tratamento de saúde, a primeira regra deve ser de não causar danos ao paciente. Somente partindo dessa premissa é que se pode pensar em produzir algum efeito terapêutico para o paciente. Ainda que sejam necessárias maiores pesquisas sobre o tema, Linden tece alguns apontamentos de grande relevância para uma primeira abordagem do tema no âmbito da clínica.

Em primeiro lugar, Linden destaca que o terapeuta deve estar atento para o fato de que reconhecer tais efeitos adversos é tarefa árdua e, portanto, devem a todo momento estar alertas, buscando observar qualquer sinal ou indício de um efeito negativo. Outro aspecto que os terapeutas devem ter em mente é a sua própria tendência pessoal a não enxergar ou a reduzir efeitos adversos, descartando-os como algo inerente ao tratamento ou mesmo algo típico da personalidade do paciente, o que só reforça a 
necessidade de se estar atento aos possíveis efeitos negativos, devendo levar questões sobre o assunto também para as supervisões, interconsultas e discussões de caso.

É preciso também que seja desconstruída a ideia de que o efeito adverso é necessariamente um dano causado por uma conduta inadequada do terapeuta e, portanto, passível de punição. Todos os terapeutas estão sujeitos a causar riscos ao paciente, como é inerente a qualquer tratamento de saúde. A questão, então, não envolve uma eliminação dos efeitos adversos, mas sim um maior cuidado com o tema, buscando ao máximo reduzir sua ocorrência. O bom terapeuta não seria aquele que evita todo e qualquer efeito adverso, o que seria impossível, mas sim aquele capaz de identificar tais efeitos e atuar para minimizar ou contornar eventuais danos causados.

Para que tudo isso seja possível, é necessário que a questão da identificação e prevenção de efeitos adversos ganhe maior evidência dentre os profissionais, sendo objeto de mais pesquisas e de debates nos congressos e fóruns de discussão e, também, que o tema se torne parte integrante da formação dos psicoterapeutas.

Dimidjian \& Hollon (2010) é outro a concordar com a importância de que o tema seja abordado abertamente nos fóruns de discussão, promovendo pesquisas sistemáticas e evidenciando esta problemática, por meio de discussões francas e abertas entre psicoterapeutas e também na comunidade, tratando de modo mais direto a questão dos possíveis danos causados por um tratamento psicoterápico, sendo esse o caminho possível para redução dos riscos de efeitos adversos no curso do tratamento.

Jarret (2007) também aborda as dificuldades envolvidas na pesquisa sobre o tema. Segundo Jarret, as evidencias mostram que a taxa de pacientes que pioram após início do tratamento psicoterapêutico é de aproximadamente 10\%. Mas mesmo diante desses resultados, boa parte dos profissionais simplesmente desconhece o fato de que o tratamento ofertado pode causar mal.

Neste sentido, cumpre destacar a pesquisa de Boisvert \& Faust (2007), em que foi realizada uma consulta com 181 psicólogos em atividade espalhados pelos Estados Unidos, verificando-se que $28 \%$ dos entrevistados não estavam sequer cientes da possibilidade de que o tratamento psicoterapêutico possa causar efeitos adversos. Os 
resultados da pesquisa demonstraram também que tais profissionais tinham pouco conhecimento acerca de pesquisas que vinham sendo realizadas sobre a eficácia e efeitos adversos dos tratamentos com os quais trabalham.

Berk \& Parker (2009), reconhecem que seja compreensível que a questão acerca da possibilidade de uma psicoterapia ter efeitos colaterais ou causar danos ao paciente pareça estranha em um primeiro momento, acompanhando a opinião também de Nutt \& Sharpe (2008), de que haveria, entre psicoterapeutas, certa presunção de que, por se tratar "apenas de uma conversa", de um tratamento não invasivo, o tratamento psicoterápico não teria o poder de causar mal. Mas os autores notam também que, mesmo do lado do paciente, é incomum que sejam levantadas questões acerca do potencial risco do tratamento, sendo raros casos em que o paciente interpela o profissional acerca dos riscos envolvidos, de modo contrário ao que ocorre, por exemplo, quando um médico prescreve um medicamento e, em seguida, o paciente logo pergunta sobre possíveis efeitos colaterais.

Outra dificuldade apontada por Berk \& Parker (2009) é o fato de que a psicoterapia, ao contrário do que ocorre, por exemplo, com o uso de medicação, não permite ao paciente estabelecer claramente uma relação clara de causa e efeito entre o tratamento e algum efeito adverso experienciado. Muitas vezes o efeito adverso de um tratamento psicoterapêutico demora a se manifestar e aparece de modo gradual, ao contrário do que muitas vezes acontece com os efeitos colaterais de medicamentos, em que o efeito tende a ser mais rápido e contundente.

Os resultados expostos acima demonstram algumas das principais dificuldades que se deve ter em mente ao abordar o tema dos efeitos iatrogênicos. Ao contrário do que ocorre na Farmacêutica, ou mesmo na Medicina, no campo das psicoterapias o desafio de identificar e prevenir efeitos iatrogênicos é muito maior, sendo necessário considerar uma multiplicidade de fatores.

Destes resultados, dois pontos nos interessam especialmente. O primeiro ponto é o argumento de que o primeiro passo para que se possa avançar na investigação sobre o tema está na possibilidade de definir uma terminologia adequada, operadores que 
possibilitem identificar, classificar e analisar os possíveis efeitos iatrogênicos decorrentes do tratamento. Tal tarefa será abordada no capítulo subsequente.

O segundo ponto de interesse é o consenso encontrado na literatura ao indicar que a via para redução dos riscos iatrogênicos dos tratamentos passa também pela possibilidade de que os profissionais ampliem os debates acerca desse tema, estando atentos para investigar e discutir os eventuais efeitos iatrogênicos que os tratamentos oferecidos venham a causar. 


\section{Capítulo 3 - ClassificaÇões no Campo da IATrogenia}

Como visto, o tema dos possíveis efeitos iatrogênicos que podem ser resultantes de um tratamento - seja ele médico, psicoterapêutico ou psicanalítico - é pouco explorado na literatura no campo da psicologia ou da psicanálise, havendo uma escassez de pesquisas sobre o tema. Um dos motivos para isso, conforme destacado na própria literatura sobre o tema, é que a pesquisa nesta área enfrenta uma série de dificuldades metodológicas. Dentre estes obstáculos metodológicos, se destaca a falta de um sistema conceitual adequado que possibilite a identificação e classificação dos possíveis efeitos iatrogênicos, permitindo assim seu estudo.

Neste capítulo, então, será feito o esforço de construir alguns aspectos iniciais acerca de uma possível terminologia que oriente o restante desta pesquisa sobre o tema. Ainda que não seja possível esgotar completamente o tema e suas possibilidades de classificação, a ideia é que se possa ter em mente os principais aspectos envolvidos quando se utiliza o conceito de iatrogenia ou, ainda, termos correlatos, como a noção de erro médico, efeito colateral, efeito adverso, dentre outros, estabelecendo um repertório terminológico mínimo que possa ser usado como operador para o restante do trabalho.

Como dito, a falta de clareza conceitual para definição do que configura uma iatrogenia representa um dos grandes desafios para pesquisa sobre o tema (Padilha, 2001). A revisão da literatura sobre o tema mostra que diversos termos são usados de maneira mais ou menos intercambiável na literatura, sem maior clareza acerca de seus significados e a distinção entre eles: efeitos iatrogênicos, efeitos colaterais, efeitos indesejados, efeitos adversos, danos, prejuízos, dentre outros (Padilha, 2001).

Um ponto importante de discussão é o que engloba as questões acerca do possível alcance das iatrogenias. Questões como se a iatrogenia alcançaria apenas o paciente ou poderia alcançar também outras pessoas, como amigos ou familiares do paciente. Ou então se a ocorrência de iatrogenias está localizada apenas como efeitos de tratamentos ou se poderia também ser localizada como efeito de ações realizadas por 
outros atores, podendo se falar em iatrogenias institucionais ou mesmo sociais. Outra questão é quais acontecimentos poderiam ou não ser enquadrados como iatrogenias, se o uso do termo se restringe aos casos de prejuízos acidentais ou se engloba danos causados deliberadamente pelo terapeuta ou até mesmo prejuízos causados por fatores externos ao tratamento.

Vimos que áreas como Medicina, Farmacologia, Psicologia, Direito, Sociologia, fazem uso do termo, mas com concepções diversas, com maior ou menor abrangência, fornecendo respostas por vezes diversas para as questões apresentadas acima. Mesmo dentro de um único campo, há disputas na literatura acerca do que exatamente poderia ser considerado como uma iatrogenia.

Diante deste cenário, será realizado nesse capítulo um breve percurso pelas principais questões classificatórias sobre o termo, nas diversas áreas do saber, destacando alguns dos problemas enfrentados na tentativa de definição do conceito de iatrogenia para que, ao final do capítulo, seja possível estabelecer uma organização acerca do que se entende por iatrogenia e quais seriam suas modalidades ou subcategorias. Basicamente, a tese central a ser trabalhada é de que o campo das iatrogenias é amplo, englobando uma série variada de fenômenos que vão desde casos mais gerais como a iatrogenia social ou a institucional, até os casos mais específicos como um efeito iatrogênico resultante de atuação imprudente do terapeuta em um atendimento, por exemplo.

Um primeiro ponto de discussão que se apresenta é o alcance do termo iatrogenia, seus limites, ou seja, se ele estaria circunscrito apenas à área médica e, mais especificamente, ao âmbito da relação médico-paciente ou se poderia ir além desses casos. Foucault (1979) e Gaudenzi \& Ortega (2012) destacam o modo como a medicina cada vez mais assume a gestão do corpo e da vida humana, medicalizando a sociedade, uma conduta que leva a uma patologização de elementos do curso natural da vida e, consequentemente, patologizando cada vez mais fenômenos naturais, com grandes prejuízos para a sociedade. Para esses autores, ao se considerar esse tipo de domínio da medicina sobre a vida das pessoas e os riscos que ela representa para a população, poderíamos falar em efeitos iatrogênicos da cultura médica sobre a sociedade. 
Neste sentido, e considerando essa possibilidade de efeitos iatrogênicos no âmbito social, o crítico social Ivan Illich (1975) ampliou o conceito médico de iatrogenia em seu livro Medical Nemesis: The Expropriation of Health, ao estabelecer uma segmentação e classificação da iatrogenia em três níveis distintos.

Em primeiro lugar, o nível mais restrito, seria o da iatrogenia clínica, ou seja, aquela no âmbito da relação médico-paciente, em que se trata do dano causado aos pacientes por tratamentos ineficazes, inseguros ou errados. O segundo nível seria o da iatrogenia social, que se aproxima do que é sugerido por Foucault, ou seja, uma iatrogenia que engloba a já mencionada medicalização da vida, em que as indústrias médica e farmacêutica têm interesses comerciais diretos em incentivar e patrocinar o adoecimento $\mathrm{O}$ terceiro nível, ainda mais amplo, seria o da iatrogenia cultural, que se refere à destruição de meios tradicionais de lidar com a morte, com o sofrimento e com o adoecimento. A medicalização da vida em nossa sociedade, aos poucos degrada construções culturais acerca desse processo de adoecimento, vida e morte, causando danos à sociedade que, aos poucos, vai perdendo seus meios autônomos e tradicionais de lidar com essas situações.

Surge, então, um primeiro ponto que podemos considerar para o nosso objetivo: a questão do alcance do conceito da iatrogenia que, pelo que aponta a literatura, pode ir além da mera relação profissional-paciente, podendo estar presente como efeitos de uma instituição, de um sistema de saúde ou mesmo da cultura médica como um todo.

Outra questão sobre o alcance das iatrogenias é a colocada por Crown (1983), ao afirmar que as repercussões de um trabalho psicoterapêutico vão muito além do próprio paciente, alcançando também pessoas do círculo de convivência mais próximo ao paciente, como família e amigos. Se uma estrutura familiar é desfeita, como resultado de uma mudança radical de comportamento de uma pessoa ou por uma decisão abrupta, como pedido de divórcio, decorrentes do trabalho realizado na psicoterapia, os resultados negativos podem afetar toda a família. Crown propõe, então, uma distinção entre os efeitos sofridos pelo paciente e efeitos sofridos por outras pessoas a seu redor. 
Apesar das considerações expostas acima, no geral, o conceito de iatrogenia é mais amplamente utilizado para se referir ao âmbito dos serviços de saúde, em especial, a relação médico-paciente, sendo o paciente a vítima da ocorrência desses efeitos. É neste escopo que o presente trabalho pretende focar e é também neste escopo que surge a maior gama de pontos de dúvida acerca do conceito de iatrogenia.

Logo de cara, surge a questão sobre quais profissionais poderiam ser potenciais causadores de iatrogenias. No campo do Direito discute-se quais profissionais de saúde poderiam ser enquadrados na categoria de erro médico prevista legalmente. Apesar do debate sobre o tema, a doutrina e jurisprudência jurídica, já parecem indicar de modo pacífico o entendimento de que o erro médico diz respeito às práticas de saúde em geral, o que engloba todos os profissionais envolvidos, por exemplo, enfermeiras e também outros funcionários do hospital, ou mesmo outros profissionais de saúde que atuem fora da cena hospitalar (Bittar, 1991).

A questão, então, é se o mesmo raciocínio poderia ser transposto também para o conceito de iatrogenia, podendo ser aplicado não apenas aos médicos mas a toda espécie de tratamentos de saúde, seja na cena hospitalar ou fora dela. As indicações de Illich e Foucault ao ampliarem o termo iatrogenia até mesmo para níveis mais amplos, podem permitir inferir que o conceito deve englobar também esses profissionais não médicos. Além disso, podemos localizar pesquisas em áreas como Farmacologia, Psicologia e mesmo Odontologia que também abordam o tema das iatrogenias do tratamento, o que atesta que essas áreas consideram a possibilidade de que sua prática também possa levar à ocorrência de efeitos iatrogênicos.

Como visto também, desde tempos antigos, na Grécia, já se sabia da possibilidade de que tratamentos causassem danos ao paciente, antes mesmo de uma divisão rigorosa da Medicina como área específica dentro dos procedimentos de cura. Também como já mencionado anteriormente, Balint (1957) afirma que todo tratamento eficaz é, em maior ou menor grau, capaz também de causar prejuízos. Pode-se concluir, então, que não há motivo para que o termo iatrogenia fique restrito apenas às práticas médicas, podendo englobar também a atuação de outros profissionais da área da saúde. 
Outra questão que se faz presente na literatura médica, é a distinção entre iatrogenias por ação, para casos em que a iatrogenia é causada por uma ação do profissional de saúde, e iatrogenia por omissão, para casos em que a iatrogenia é causada por uma omissão por parte do médico (Pereira, 2000). Assim, é importante ter em mente, ao se discutir a questão das possíveis iatrogenias, que elas podem ser resultantes não apenas de ações equivocadas por parte do profissional mas também por omissões indevidas.

Outra questão classificatória, já mencionada anteriormente, está na dificuldade de diferenciar o termo iatrogenia de outros termos correlatos que, por vezes, são utilizados de modo intercambiável na literatura. Em textos brasileiros é comum uma falta de clareza nas distinções entre os conceitos de iatrogenia e erro médico, por exemplo, tanto no campo do Direito, quanto no da Medicina. Tal distinção tem implicações jurídicas de grande importância, para subsidiar a discussão acerca dos casos em que o profissional pode ou não ser responsabilizado juridicamente pelos danos causados ao paciente. Já na literatura norte-americana, é comum a confusão entre iatrogenia e termos como reações adversas, efeitos colaterais, efeitos adversos, efeitos não desejados, dentre outros, o que dificulta a investigação sobre esse tema.

$\mathrm{Na}$ literatura sobre o tema, considerando as diversas terminologias empregadas, o principal ponto de confusão parece se estabelecer entre os conceitos de iatrogenia e de erro médico. Tal debate talvez seja o mais complicado e o que se apresenta de modo mais aprofundado na literatura, tanto médica, quanto jurídica.

Uma posição comum sobre o assunto é uma espécie de oposição entre os conceitos: pelo conceito de erro médico entende-se aquilo que está necessariamente ligado a alguma espécie de falha ou vício de conduta por parte do médico, ficando relegados à categoria de iatrogenias os casos que não se relacionam a um erro ou falha, casos em que um tratamento adequadamente escolhido e devidamente aplicado cause efeitos iatrogênicos no paciente. Muitas vezes tais efeitos são até mesmo previstos e esperados, como no caso da perda de cabelo ou o enjoo em pacientes que passam por tratamento quimioterápico. 
Contudo, uma análise mais minuciosa dos fenômenos possíveis na prática de saúde e também com o uso de outros conceitos mais refinados, demonstra que tal oposição simples, entre iatrogenia como algo acidental e erro médico como falha do profissional, não se sustenta. Uma adequada distinção entre os dois conceitos tem especiais implicações no ramo do Direito, vez que a partir dela é que se irá definir em quais casos o profissional poderá ser responsabilizado civilmente, ou mesmo criminalmente, pelo efeito adverso ocorrido. Contudo, apesar dessa importância, mesmo no ramo do Direito o tema gera controvérsias, podendo ser localizadas três correntes diversas na literatura sobre o assunto.

A primeira corrente segue a já mencionada polarização, em que iatrogenia só se configura quando a conduta médica é adequada, mas mesmo assim um dano se ocorre, e, portanto, esse cenário não seria passível de responsabilização jurídica, enquanto que o conceito de erro médico seria utilizado apenas para casos de falhas no atendimento e, portanto, passíveis de responsabilização. Neste sentido o entendimento esposado pelo desembargador Souza (1997) e também pelo desembargador Carvalho (2009) que, em sua obra específica sobre esse tema, define iatrogenia como:

"um atuar médico de forma correta, necessária, consubstanciado no uso de técnicas e medicamentos necessários para enfrentar crises ou surtos, que causam danos em pessoas sadias ou doentes não ensejadores de responsabilidade civil".

Assim, a iatrogenia seria também causa excludente de responsabilidade por parte do profissional, ou seja, configurado mero efeito iatrogênico, acidental e inerente ao tratamento, não haveria de se falar em responsabilização jurídica, que só ocorreria nos casos de erro médico.

Contudo, essa divisão rígida entre erro médico e iatrogenia não é posição dominante na doutrina. Há uma segunda corrente, mais prevalente, que defende a noção de iatrogenia como todo e qualquer prejuízo causado pelo médico ou pelo tratamento ao paciente, de modo que a iatrogenia englobaria todos os casos de danos, inclusive o erro 
médico, que seria apenas uma subcategoria da iatrogenia, além dos casos em que não houve erro mas houve dano.

$\mathrm{O}$ argumento a favor desse entendimento é a noção de que um médico, ainda que disponha dos melhores recursos tecnológicos diagnósticos e terapêuticos, é sempre passível de cometer iatrogenias, sendo a iatrogenia, de certo modo, algo inerente à própria atuação na área da saúde. Como já visto, Balint (1957) segue esse raciocínio ao afirmar que todo médico é, em graus variáveis, iatrogênico, de modo que ele deve sempre considerar este aspecto quando trata seu paciente.

A iatrogenia, então, abrangeria os danos materiais e também os psicológicos causados ao paciente não só pelo médico como também por sua equipe e por outros profissionais de saúde (enfermeiros, psicólogos, assistentes sociais, fisioterapeutas, nutricionistas e demais profissionais), englobando tanto casos de erro como casos de conduta adequada. Sob esta óptica, os "erros médicos", com seus critérios estabelecidos pelo Código de Ética Médica e também no Direito Civil (imperícia, imprudência, negligência) se enquadrariam como subcategoria das iatrogenias.

Moraes (2003) segue essa lógica ao definir três tipos de iatrogenia. A primeira seria a que engloba as lesões previsíveis e esperadas, uma vez que o procedimento em si próprio pode implicar em sequelas no paciente, como no exemplo da queda de cabelo em decorrência de quimioterapia. A segunda é a das lesões previsíveis, porém, inesperadas, lesões decorrentes do perigo existente em todo e qualquer procedimento médico, que escapam ao controle mesmo do médico mais experiente. Seria o caso de morte do paciente numa cirurgia mesmo tendo havido conduta adequada por parte dos profissionais. A terceira categoria seria a que agrupa as lesões decorrentes da falha do profissional de saúde no exercício da sua profissão, sendo essas falhas deste terceiro grupo sujeitas a responsabilização legal do médico.

Por fim, uma terceira via na doutrina, ainda que minoritária, é a defendida por Couto \& Souza (1999), que pretende uma conciliação entre as duas linhas anteriores, ao proporem que o termo iatrogenia pode ser visto sob dois aspectos: lato sensu e stricto sensu. No sentido lato, pode-se entender a iatrogenia como o resultado danoso causado 
ao paciente pela atuação do médico, seja o ato realizado com falha no atuar, caracterizando um proceder imprudente, negligente ou imperito, seja esse ato realizado dentro das normas recomendadas. Já no sentido stricto, a iatrogenia decorre apenas de danos causados por uma atuação médica correta.

Mas, como já dito, tem maior domínio na doutrina, então, a segunda corrente, na qual o conceito de iatrogenia é tido todo como todo e qualquer efeito adverso causado por um tratamento, englobando inclusive os casos de erro médico.

Porém, mesmo nos filiando a esta corrente dominante da doutrina, resta ainda como questão se tal definição de iatrogenia englobaria também os casos de conduta dolosa por parte do profissional, casos em que o profissional deliberadamente opta por uma ação que causará danos ao paciente, como no exemplo do profissional de saúde que, tirando vantagem de sua posição, abusa sexualmente do paciente.

Poder-se-ia argumentar que tal conduta é completamente fora de qualquer protocolo de atendimento ou ética de conduta profissional, o que poderia descaracterizálo como possível efeito de um tratamento, vez que o ato do abuso, em si, é alheio ao tratamento. Porém, parece que o mais sensato seria reconhecer que, ainda que o ato de abuso não seja inerente ao tratamento, na maioria dos casos tais profissionais se utilizam da situação de tratamento e da vulnerabilidade de seus pacientes para realizar o abuso, de modo que a cena médica foi o que propiciou tal abuso, permitindo que possa ser enquadrado como um efeito adverso do tratamento e, portanto, dentro do conceito de iatrogenia.

Ainda que estabelecido que o erro médico é subcategoria das iatrogenias, restaria, ainda, a questão de definir o que configuraria o erro médico e quais seriam os critérios para identificar sua ocorrência e, principalmente, distingui-lo de outros casos de iatrogenia não resultantes de erro.

Juridicamente, para configuração do erro médico é necessária uma falha, via ação ou omissão, por parte do profissional de saúde e que cause dano ao paciente. Além disso, é necessário que fique configurada a ocorrência de um ou mais dos seguintes elementos: negligência, imprudência ou imperícia na conduta do profissional. Tais 
elementos estão previstos na legislação e também no Código de Ética Médico que ao tratar da responsabilidade do profissional determina que é vedado ao médico "praticar atos profissionais danosos ao paciente, que possam ser caracterizados como imperícia, imprudência ou negligência" (CFM, 2009, art. 29). Além desses critérios, Moraes (2003) afirma que é preciso também que haja nexo efetivo de causa e efeito entre o procedimento médico e o dano causado, para que se configure o erro médico.

Ao se falar em negligência, refere-se a hipóteses de omissão ou descaso por parte do profissional, falta do devido cuidado, atenção, diligência ou aplicação por parte do profissional em um determinado procedimento. Já a imprudência está mais relacionada ao profissional que age de modo apressado e assume riscos desnecessários, atuando sem a devida precaução ou cautela, de forma descuidada, sem atenção aos padrões científicos que deveriam orientar sua conduta. Por fim, a imperícia se relaciona à falta de domínio das técnicas, falta de capacidade ou habilidade, falta de experiência ou competência específica para realizar um determinado procedimento ou intervenção, podendo ser resultado de ignorância, inexperiência ou inabilidade sobre a arte ou profissão que pratica (Bittar, 1991).

No dizer de França (1998, apud Carvalho, 2005, pg. 45), negligente é aquele que "pela inação, indolência, inércia, passividade falta aos deveres que as circunstâncias exigem"; imprudente é o médico cujos atos "são caracterizados pela intempestividade, precipitação, insensatez ou inconsideração"; e imperito é o médico que "por despreparo prático ou por insuficiência de conhecimentos técnicos" deixa de observar as normas técnicas fundamentais para o exercício da profissão.

Erro médico, em suma, pode ser classificado como o mau resultado ou resultado adverso decorrente da ação ou da omissão do médico, por inobservância de conduta esperada e na qual devem estar presentes ao menos um dos três elementos (negligência, imprudência ou imperícia).

Importante destacar mais uma vez que tais casos tidos como erro médico se referem às hipóteses de casos em que não houve intenção do profissional em causar danos ao paciente, ou seja, condutas culposas por parte do profissional. Diferem-se, 
então, dos casos de conduta dolosa, que geram, evidentemente, responsabilidade civil e até mesmo criminal. O médico que, deliberadamente, realiza um procedimento de modo equivocado, a fim de prejudicar um paciente, será responsabilizado por essa agressão, e não por erro médico, inclusive com a possibilidade de resposta na esfera penal.

Há, ainda, na literatura estrangeira, outros problemas terminológicos acerca da iatrogenia. Verifica-se o uso intercambiável entre termos como "side effects", "adverse effects", "iatrogenesis", e "iatrogenic disorders". A fim de estabelecer uma distinção entre esses conceitos, Ghraiba (2006) insere como elemento distintivo a cronicidade ou a permanência a longo prazo do dano causado como elemento que tipifica a iatrogenia. Um mero "adverse effect" ou "side effect" seria algo que passa rapidamente quando se encerra o tratamento como, por exemplo, o mal estar causado como efeito colateral de um medicamento e que cessa quando se interrompe a medicação. Já para iatrogenia estamos falando em danos que permanecem, mesmo depois de encerrado o tratamento.

Mais uma vez se repete o problema de entender se um dano decorrente do tratamento pode ser excluído da esfera das iatrogenias. Ou seja, ainda que aceitemos que um mero "adverse effect" ou "side effect" é aquele não dotado dos critérios de cronicidade ou longo prazo de permanência do efeito nocivo, isso quer dizer que tais fenômenos estariam excluídos da lista de iatrogenias? Não parece haver motivos para tal entendimento, sendo mais frutífero manter a noção de iatrogenia como grande área, dentro da qual encontramos diversas categorias ou subdivisões, tais quais o próprio conceito de erro médico ou as hipóteses de "adverse effect" ou "side effect", sendo que o que se faz necessário é justamente o esforço para identificar e classificar essas subcategorias.

Neste sentido, reconhecendo a iatrogenia como campo amplo no qual se localizam diversas subcategorias, merece especial destaque o trabalho de Linden (2012). Partindo do problema que representa a falta de pesquisa sobre os possíveis efeitos adversos das psicoterapias e da falta de conceitos teóricos capazes de orientar os estudos sobre o tema, Linden se propõe a elaborar um modelo que permita definir, classificar e avaliar os possíveis efeitos negativos dos tratamentos. 
O autor propõe, então, uma divisão entre uma primeira grande categoria, a de eventos não desejados (unwanted events). Dentre dessa categoria, temos uma subcategoria para reações resultantes do tratamento (treatment-emergent reactions) e outra para reações não decorrentes do tratamento mas sim resultantes de deterioração no próprio curso da doença (deterioration of illness). Dentre as reações resultantes do tratamento, teríamos ainda duas outras subcategorias: uma para reações adversas resultantes da aplicação correta do tratamento (adverse treatment reactions) e outra para reações adversas causadas por erro do médico na condução do tratamento (malpractice reactions). Há ainda uma categoria para os casos em que o paciente não responde ao tratamento aplicado adequadamente (treatment non-response). A partir dessas categorias, Linden propõe que sejam definidos quais são os riscos terapêuticos (therapeutic risks) e as contraindicações (contraindications) dos tratamentos, ou seja, quais os riscos envolvidos e cada tratamento e para quais casos cada tratamento não é indicado, devendo tais informações serem passadas ao paciente antes do início do tratamento. A ideia é de que esses conceitos sejam capazes de abarcar os diversos tipos de variáveis de efeitos negativos de um tratamento, sendo suficientes para serem utilizados como ferramentas para análise de casos clínicos e identificação e classificação dos efeitos adversos ocorridos. A tabela abaixo demonstra essas categorias e suas definições, como propostas por Linden (2012): 


\begin{tabular}{ll}
\hline Efeitos Colaterais & Definições \\
\hline Eventos Indesejados (EI) & $\begin{array}{l}\text { Todos efeitos negativos que ocorrem paralelamente ou no âmbito do } \\
\text { tratamento }\end{array}$ \\
$\begin{array}{l}\text { Reações Decorrentes do } \\
\text { Tratamento (RDT) }\end{array}$ & Qualquer EI que seja causada pelo tratamento \\
Reações Adversas ao & Qualquer EI provavelmente causada pelo tratamento adequado \\
Tratamento (RAT) & Qualquer EI que seja provavelmente causada pela aplicação incorreta \\
Reação por Erro Médico & ou inadequada do tratamento \\
(REM) & Ausência de melhora no quadro clínico, mesmo após o tratamento. É \\
Tratamentresposta ao & uma EI. Pode ou não ser uma RAT ou uma REM \\
Deterioração da Doença & Piora no quadro clínico durante o tratamento ou em qualquer \\
(DD) & momento do adoecimento. Não necessariamente é uma EI. Mas pode \\
ser uma EI e, caso seja, pode ou não ser uma RAT ou REM & Todas as RATs que são conhecidas. Pacientes tem o direito de serem \\
Risco Terapêutico (RI) & informados sobre os riscos frequentes ou severos que um tratamento \\
possa produzir, sendo a base da ideia de consentimento esclarecido \\
para o tratamento \\
Características de determinados quadros clínicos que aumentam \\
amplamente a possibilidade de ocorrência de RATs. Uma RAT \\
decorrente de uso do tratamento, desconsiderando CIs, se qualificaria \\
como uma REM
\end{tabular}

Tabela 1: Proposta de classificação de iatrogenias no campo das psicoterapias, conforme Linden, 2012)

Não cabe neste momento descrever de modo mais minucioso a metodologia proposta por Linden, mas a ideia segue a lógica já proposta anteriormente: de uma categoria geral de iatrogenias que abarca diversas subcategorias. Assim, haveria um grupo mais amplo que é o dos eventos ou efeitos não desejados, ou seja, qualquer efeito negativo que possa ocorrer com o paciente que se encontra em atendimento, se aproximando da definição que, neste trabalho, demos para o conceito de iatrogenia.

Ainda sobre os efeitos não desejados, Linden destaca a importância de que eles sejam monitorados de modo geral e abrangente, sem maiores pretensões interpretativas. Primeiro deve-se identificar tais eventos e, somente depois, com o curso do tratamento é que será possível interpretar ou compreender o significado desses eventos para o paciente e o sentido deles dentro do quadro clínico, podendo-se então classificá-lo dentro de uma das categorias propostas. Inclusive, Linden argumenta que grande parte do motivo pelo qual os terapeutas não conseguem identificar efeitos negativos é pela excessiva busca primeiro por interpretações e conceitualizações, antes de focar em apenas identificar potenciais sinais negativos que mereçam mais investigação. 
Neste sentido é importante destacar também o trabalho de Lambert (2007), ao desenvolver um sistema de pesquisa, utilizado ao longo de mais de uma década, envolvendo o monitoramento da resposta de pacientes ao tratamento psicoterapêutico. A partir do uso de questionários aplicados aos pacientes antes de cada sessão, o sistema desenvolvido por Lambert foi capaz de estimar qual seria o tempo de terapia necessária para recuperação de cada paciente, estudar casos em que a melhora se deu antes do esperado e também verificar se intervenções mais precoces no curso do tratamento seriam capazes de melhorar o desfecho daqueles pacientes cuja previsão era de uma má resposta ao tratamento. A proposta do autor segue o sugerido por Linden (2012), ou seja, um monitoramento constante em busca de efeitos adversos.

Segundo Lambert (2007), em média, um paciente que não está tendo bons resultados com um tratamento apresenta resultados até $20 \%$ piores de desempenho nos questionários do que a média dos pacientes submetidos ao mesmo tratamento. Com o uso do sistema, Lambert afirma ser capaz de prever e reduzir os prejuízos causados por efeitos iatrogênicos do tratamento.

O mérito desse tipo de alternativa é justamente contornar o fato de que terapeutas tem uma tendência a não identificar os efeitos adversos dos tratamentos que aplicam. Assim, por meio dos questionários, o terapeuta teria sempre um acompanhamento dos casos que não estão tendo boa evolução. Lambert (2007) faz um paralelo entre o uso de feedbacks na psicoterapia e a prática de tomar a pressão sanguínea do paciente em uma consulta médica, como práticas que devem ser realizadas reiteradamente a cada consulta, a fim de identificar o mais cedo possível eventuais problemas, antes que se tornem mais graves, estabelecendo uma postura mais ativa por parte dos profissionais, ao invés de uma postura essencialmente reativa como ocorre atualmente.

Ainda que a ideia de aplicar semanalmente questionários aos pacientes não pareça muito prática ou mesmo adequada, a ideia a ser extraída aqui é a importância de que os profissionais possam estar atentos para acompanhar em que medida o tratamento tem causado impactos ao paciente. 
Em uma pesquisa realizada com 40 psicoterapeutas, Lambert solicitou que os profissionais tentassem prever quais de seus pacientes sofreriam uma piora no curso do tratamento. Foi informado para esses terapeutas que a taxa média de piora de pacientes no curso do tratamento é de $8 \%$. Ainda assim, com um total de mais de 500 pacientes analisados pelos 40 participantes da pesquisa, quase nenhum foi considerado como um caso de possível piora ao longo do tratamento. Já os métodos de análise e algoritmos utilizados por Lambert para avaliar os pacientes foram capazes de identificar quase $90 \%$ dos casos que, de fato, vieram a piorar no curso do tratamento. Os psicoterapeutas entrevistados, por outro lado, foram capazes de identificar apenas 3\% dos casos de piora.

Mas, retomando a classificação proposta por Linden (2012), além de propor o monitoramento constante em busca de efeitos não desejados, Linden destaca que eles podem ou não estar relacionados ao tratamento, podem ou não ser resultado da conduta do terapeuta, dentre outras variáveis, o que justifica as categorias subsequentes. Tais categorias poderiam, inclusive, ser utilizadas para definir quais casos ensejariam ou não responsabilização jurídica.

Fica claro que tais categorias não abarcam a totalidade dos efeitos iatrogênicos possíveis e já discutidos anteriormente neste texto, como os casos mais amplos de iatrogenia sociais ou institucionais ou os casos de abusos dolosos por parte do terapeuta. Mas o importante a se extrair daqui é a proposta de que, a partir de um campo mais amplo, o das iatrogenias, possam ser definidas subcategorias ou conceitos que permitam classificar e organizar o campo dos possíveis efeitos iatrogênicos decorrentes de um tratamento. Sendo elaborada e aperfeiçoada essa classificação, serão possíveis avanços no campo da pesquisa e nos debates sobre o tema, vez que haverá maior precisão teórica para analise dos fenômenos que se apresentam na clínica.

A partir dos resultados apresentados nesse capítulo e tomando como base principalmente o trabalho de Linden, extraímos uma primeira proposta de classificação que será utilizada para a continuidade desta pesquisa sobre o potencial iatrogênico da psicanálise. 
Essa classificação toma, então, o campo das iatrogenias como uma categoria geral, que pode ser dividida em dois grupos. Um primeiro grupo para os efeitos iatrogênicos causados pelo tratamento mesmo quando aplicado de forma adequada e um segundo grupo para efeitos iatrogênicos que ocorrem quando algo não vai bem no tratamento. Esse segundo grupo é ainda subdividido em outros dois: casos de ação dolosa do profissional, visando prejudicar o paciente e casos de ação culposa, em que ocorre um erro não intencional por parte do profissional.

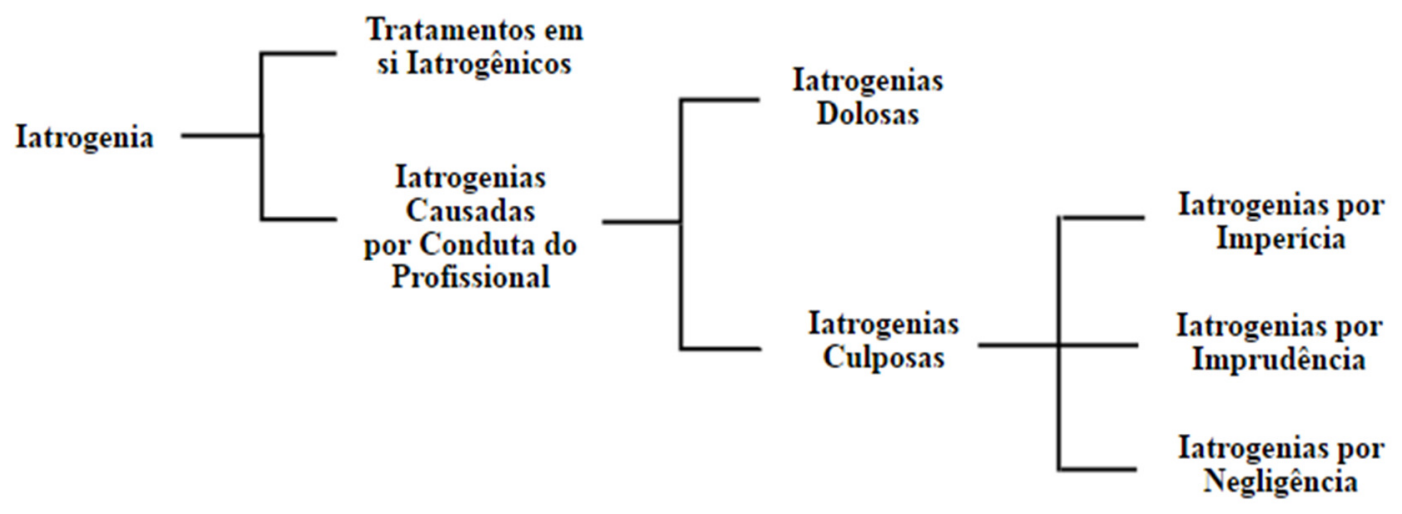

Figura 2 - Proposta de esquema de classificação das iatrogenias

Munidos dessa proposta de classificação, partimos no capítulo seguinte para apresentação de alguns dos principais resultados encontrados na literatura para pesquisas sobre efeitos iatrogênicos dos tratamentos psicoterapêuticos e quais são os elementos que podem contribuir para sua ocorrência. Os resultados serão apresentados já em conformidade com a proposta de classificação apresentada acima. 


\section{Capítulo 4 - 0 que Se Sabe Sobre o Potencial IATROGÊNICO DAS PSICOTERAPIAS}

Como visto no item anterior, a pesquisa sobre efeitos iatrogênicos em saúde mental apresenta uma série de aspectos que dificultam sua investigação, sendo um dos principais desafios a falta de uma terminologia adequada para orientar a investigação nesse campo. Porém, apesar desses desafios, esforços têm sido feitos nessa área e alguns resultados importantes têm sido alcançados. Tais resultados, ainda que não permitam conclusões definitivas sobre o assunto, servem como indicação acerca de alguns dos pontos dignos de atenção e que justificam maiores pesquisas sobre o tema.

Nesse capítulo serão apresentados os principais resultados encontrados na literatura acerca dos efeitos iatrogênicos nos tratamentos psicoterapêuticos. Desse modo, a pesquisa começa a se aproximar da questão principal, que são os efeitos iatrogênicos dos tratamentos psicanalíticos. Como já mencionado, a literatura nacional e psicanalítica sobre o tema ainda é escassa, mas o objetivo do capítulo é de apresentar um panorama geral do que é possível encontrar, atualmente, na literatura sobre o tema.

Para este capítulo já será adotada a classificação definida no capítulo anterior, dividindo as iatrogenias em três grupos: iatrogenias dolosas, iatrogenias culposas e tratamentos em si iatrogênicos.

Assim sendo, iniciamos o capítulo com a questão acerca das iatrogenias por ação dolosa por parte do profissional.

\section{IATROGENIAS DOLOSAS}

Como visto no capítulo sobre definições e classificações no campo das iatrogenias, uma possibilidade a ser considerada e incluída no campo das iatrogenias é a dos casos de abusos deliberados por parte do profissional e que ocorrem na cena médica ou como decorrência da relação de trabalho estabelecida com o paciente. Assim, trata-se 
de casos em que o terapeuta conscientemente adota uma postura que sabe que poderá causar danos ao paciente. Neste sentido são também condutas às quais cabem maiores implicações jurídicas, sendo passível inclusive de julgamento e condenação na esfera penal.

Na área médica não são raros casos noticiados até mesmo na mídia sobre esse tipo de abusos cometidos contra pacientes. Podemos relembrar, por exemplo, o caso do ex-médico Roger Abdelmassih, especialista em fertilização in vitro e que em 2010 foi condenado a 278 anos de prisão por 56 estupros contra pacientes ${ }^{2}$. Mais recentemente, em 2015, o caso da médica Virgínia Soares de Souza, responsável pela Unidade de Tratamento Intensivo (UTI) do Hospital Evangélico de Curitiba, e indiciada sob acusação de que sua equipe promovia morte antecipada de pacientes em estado terminal ${ }^{3}$. O caso ainda aguarda julgamento.

Os exemplos mencionados acima são casos mais extremos, mas há uma gama de possibilidades de abuso que podem ocorrer, desde ofensas ao paciente, até casos mais graves, como o de abuso sexual ou homicídio. Não cabe aqui esgotar todas essas variáveis. Até por suas implicações jurídicas, a questão das ações dolosas por parte do profissional nos parecem estar situadas mais na esfera jurídica, na maneira como o Estado deva responder a esses casos.

Não é pretensão deste trabalho que ele possa alcançar ou impactar profissionais decididos a cometerem abusos contra seu paciente. Justamente por se tratar de conduta dolosa, deliberada, por parte do profissional, já está prevista a ocorrência do dano ao paciente, afastando esses casos do campo de nossa investigação, que visa pensar as possibilidades de redução dos danos ao paciente. Desse modo, não iremos avançar de modo mais profundo à questão das ações dolosas por parte dos terapeutas. Iremos apenas destacar uma hipótese de casos de iatrogenia dolosa, que são os casos de abuso sexual contra pacientes. A escolha por esse tema se faz, em primeiro lugar, pela

\footnotetext{
2 Disponível em: http://g1.globo.com/sao-paulo/noticia/2010/11/roger-abdelmassih-e-condenado-mais-de200-anos-de-prisao.html

${ }^{3}$ Disponível em: http://g1.globo.com/pr/parana/noticia/2013/02/mortes-na-uti-do-evangelico-podem-serhomicidio-qualificado-diz-delgada.html
} 
frequência com que esses casos se repetem no campo da saúde mental e, em segundo lugar, pela convicção de que o avanço nas pesquisas e na divulgação de informações sobre esse tema possa contribuir para maior conscientização dos profissionais e da população acerca dos efeitos nocivos dessa prática, aumentando as denúncias e, potencialmente, reduzindo casos de abusos.

Sobre esse tema, também encontramos casos que recebem destaque na mídia. No Brasil, podemos destacar o caso do psicólogo Marcos Rogério de Sousa Costa, condenado a uma pena de 17 anos e nove meses de reclusão, por favorecimento da prostituição ou outra forma de exploração sexual de vulnerável, no caso, menores de idade. O psicólogo se valia da condição de psicólogo voluntário do Centro de Educação Produtiva (CEP), para se aproximar e abusar sexualmente de menores (Câmara Criminal do Tribunal de Justiça da Paraíba) ${ }^{4}$.

$\mathrm{Na}$ Inglaterra, o caso do Dr. Theodore Soutzos, um psiquiatra londrino, que teve relações sexuais com sua paciente, dizendo que tal ato teria que acontecer para "aliviar a tensão" existente entre eles, permitindo o avanço do trabalho. Após o ato, a saúde mental da mulher se deteriorou, o que a levou a tentar cometer suicídio diversas vezes, sofrendo com as advertências feitas pelo médico de que jamais poderia contar sobre o ocorrido a alguém. Além desse caso, o Dr. Soutzos é acusado de relacionamentos abusivos também com outras três pacientes entre os anos de 1999 e 2006 no hospital público de Harley Street e em outras clínicas ${ }^{5}$.

Segundo Jorgenson, Randles \& Strasburger (1991), nas últimas décadas, três grandes pesquisas foram realizadas nos Estados Unidos com esse tema, a fim de determinar a prevalência do contato sexual entre terapeuta e paciente. Em 1977, um estudo (Holroyd \& Brodsky, 1977) indicou que 12,1\% dos profissionais do sexo masculino e 2,6\% das profissionais do sexo feminino admitiram ter tido relações sexuais com seus pacientes. Já em 1979, outro estudo (Pope, Levenson, \& Schover,

\footnotetext{
4 Disponível em: http://www.jornaldaparaiba.com.br/cidades/noticia/53412_conselho-de-psicologia-semanifesta-sobre-caso-de-acusado-de-pedofilia

5 Disponível em: http://www.dailymail.co.uk/news/article-1299697/Psychiatrist-Theodore-Soutzospreyed-patients-sex-groomed-suicidal-woman.html
} 
1979) alcançou resultados semelhantes: $12 \%$ dos homens e $3 \%$ das mulheres que responderam à pesquisa declararam ter tido relações sexuais com pacientes. Quase uma década depois, tais estatísticas se mantinham estáveis, apesar dos esforços da American Psychological Association (Pope, Keith-Spiegel, \& Tabachnick, 1986). Por fim, em outra pesquisa anônima realizada via questionário, com psicólogos e psiquiatras sobre esse tema nos EUA, cerca de $10 \%$ dos entrevistados admitiu já terem se envolvido em contatos eróticos com seus pacientes (Kardener, Fuller \& Mensh, 1973). Apesar das campanhas das agências reguladoras contra esse tipo de abuso, os dados mostram que tal prática tem se mantido estável nas últimas décadas, representando um grave problema.

Outras pesquisas mostram que quase $90 \%$ dos entrevistados já sentiram atração sexual por seus pacientes. Apesar da unanimidade das organizações profissionais e conselhos de ética tanto da Psiquiatria, quanto da Psicologia, da Medicina e de outras áreas ao proibir que ocorram relações sexuais entre o profissional e o paciente, a prática mostra que tais regulamentos são pouco respeitados. A American Psychiatric Association, por exemplo, indica que pelo menos $15 \%$ dos processos legais movidos contra terapeutas envolvem abusos sexuais (Perry \& Kuruc, 1993, pg. 35):

\begin{abstract}
"Since 1980, reports of sexual contact between psychotherapists' and their patients have increased dramatically; sexual contact is currently the second leading cause of professional malpractice litigation among psychiatrists. Patient-psychotherapist sexual intimacy is the leading cause of malpractice claims against psychologists, constituting the largest single category of cases that have been reported to the American Psychological Association Ethics Committee. Between 1976 and 1986, nearly forty-five percent of all malpractice insurance claims paid on behalf of psychologists resulted from psychotherapist-patient sexual contact"
\end{abstract}

Assim, no cenário norte-americano, o debate sobre o tema já se mostra mais avançado. A relação sexual com pacientes atuais, ou mesmo ex-pacientes, já é proibida eticamente pela maioria das associações profissionais norte-americanas. Além do aspecto ético, alguns estados já têm leis específicas sobre o tema (Califórnia, por 
exemplo), tornando tal prática ilegal. Estados como Califórnia, Minnesota, Wisconsin e Illinois já editaram normas para criar uma modalidade específica de ação civil apenas para casos de pacientes que sofreram abusos sexuais por parte de terapeutas. Em outros nove estados (Califórnia, Colorado, Florida, Georgia, Iowa, Maine, Minnesota, North Dakota e Wisconsin) há também leis que tornam a relação sexual com pacientes um crime, passível de punição na esfera penal.

Apesar desses elementos e de tantos avanços na proteção oferecida aos pacientes nos Estado Unidos, no Brasil o tema passa sem maiores considerações. Os conselhos de ética das diversas profissões vedam práticas sexuais com pacientes mas são feitos pouquíssimos esforços para monitoramento ou redução da ocorrência desse tipo de casos. Sequer são feitos maiores esforços na pesquisa, para investigar com que frequência tais casos ocorrem, sendo escassos os dados sobre essa temática. Tampouco temos desenvolvimentos jurídicos específicos para tais casos.

As iatrogenias dolosas, portanto, tal qual outras práticas que visam lesar outra pessoa, devem ser objeto de políticas públicas, visando coibir e reduzir a ocorrência dessas violações. A pesquisa sobre o tema pode colaborar com dados acerca dessas ocorrências, porém foge do escopo deste trabalho, dedicado para os casos em que profissionais buscam evitar ou reduzir os efeitos iatrogênicos de seus tratamentos.

Desse modo, o escopo principal dessa pesquisa será o segundo grupo de iatrogenias, o das iatrogenias culposas, ou seja, casos em que o profissional, por algum tipo de erro em sua prática, acaba involuntariamente cometendo um ato que causa uma iatrogenia do tratamento.

\section{IATROGENIAS CULPOSAS}

Esse segundo grupo de iatrogenias é, então, aquele ao qual dedicaremos maiores atenções no percurso desse trabalho. A ideia aqui é de que mesmo o profissional mais bem intencionado pode acabar cometendo um erro ou equívoco na condução do tratamento, o que pode ter efeitos prejudiciais para o paciente. Assim, a aposta é de que 
com a investigação desses possíveis erros que podem ocorrer em um tratamento, é possível pensar em mecanismos para reduzir a ocorrência de tais erros. Por estarmos localizados no grupo de iatrogenias culposas ou iatrogenias por erro, é importante termos em mente também os conceitos de imperícia, negligência e imprudência, que serão utilizados ao longo do capítulo.

No campo das psicoterapias, trabalhos sobre iatrogenias culposas são os mais comuns. Parte das pesquisas realizadas nessa área tem dedicado maior atenção ao tipo de efeitos iatrogênicos que podem ocorrer, ou seja, monitorar e identificar quais são os efeitos negativos que podem ser decorrentes de um erro na condução do tratamento psicoterápico. Outra parte dos resultados encontrados na literatura coloca como objetivo averiguar quais seriam as possíveis fontes dos efeitos iatrogênicos. A ideia é de que, investigando e compreendendo melhor as possíveis causas de iatrogenias, seria possível traçar intervenções capazes de modelar essas causas, a fim de reduzir os possíveis danos. Seguindo esse raciocínio, Castonguay (2010) afirma que, de modo geral, os fatores potencialmente causadores de iatrogenias podem ser separados em quatro grandes categorias: aspectos pertinentes ao paciente; aspectos pertinentes ao terapeuta; aspectos da relação entre paciente e terapeuta; e, por fim, aspectos incontornáveis da situação social do paciente.

Abordaremos em seguida, primeiramente, as pesquisas sobre quais os possíveis efeitos iatrogênicos de uma psicoterapia e, em seguida, as pesquisas sobre quais seriam os possíveis fatores causadores de efeitos iatrogênicos.

\section{Os Possíveis Efeitos IATRogêNicos das Psicoterapias}

$\mathrm{Na}$ literatura podemos encontrar uma série de trabalhos que visam listar ou destacar uma série de efeitos iatrogênicos que podem ocorrer em um tratamento. Não se trata aqui de buscar compilar todas essas possibilidades. Em primeiro lugar por que se trataria de tarefa inesgotável, buscar listar todos os possíveis efeitos negativos que podem emergir em um tratamento. Em segundo lugar, pela questão metodológica 
apresentada anteriormente, acerca do fato de que um mesmo fenômeno pode configurar um efeito iatrogênico em um caso mas não em outro, o que colocaria em cheque a possibilidade e utilidade de uma lista de possíveis efeitos iatrogênicos. Desse modo, serão destacados alguns casos de efeitos iatrogênicos encontrados na literatura e que terão importância para a discussão que será proposta nos capítulos subsequentes. $\mathrm{O}$ primeiro caso é o do efeito iatrogênico de dependência do paciente ao terapeuta e o segundo caso, de certo modo relacionado, é o de alienação do paciente às crenças do terapeuta.

Segundo Berk \& Parker (2009), é comum que pacientes doentes busquem por um profissional de saúde com o qual possam estabelecer certo grau de confiança, segurança e apoio, capaz de auxiliá-lo no processo de cura. Porém, em especial nos casos de saúde mental, tal relação com o terapeuta pode sofrer maiores variações em intensidade, desde níveis normais até níveis extremos que podem configurar uma espécie de dependência patológica do paciente ao profissional de saúde, vindo a configurar um possível efeito adverso do tratamento, ao dificultar que o paciente seja capaz de sair do isolamento e de recobrar algum controle sobre sua vida. É claro que a boa relação entre paciente e terapeuta tem papel fundamental para o sucesso do tratamento, mas aqui estamos pensando nos casos em que algo dessa relação extrapola o que seria aceitável e produtivo para o tratamento, recaindo numa relação de estagnação e dependência que paralisam a evolução do tratamento.

Diante de situações como essa, Berk \& Parker (2009) defendem o uso do conceito de dependência, como possível efeito adverso também nos tratamentos psicológicos, não estando restrito apenas ao uso de medicamentos ou substância químicas. Segundo os autores, quanto mais tempo um paciente passa em tratamento independentemente da linha teórica adotada pelo terapeuta - maiores serão os riscos de uma dependência que comprometa a capacidade do paciente de tomar decisões de modo independente, havendo uma tendência a que o paciente comece a transferir suas decisões para que o terapeuta decida por ele ou, então, o risco de que o paciente, ao tomar decisões em sua vida pessoal, o faça seguindo um modelo de pensamento que é o do terapeuta e não o seu próprio. Segundo os autores (Berk \& Parker, 2009, pg. 789): 
"The risk is for the patient to remain in a therapeutically shaped 'comfort zone', distanced from the capacity and risks inherent in making their own mistakes in the real world and, more importantly, learning from them, and so shifting their interpersonal investments to limit primary and extended relationships."

Assim, um primeiro alerta encontrado na literatura está no risco de excesso de tratamento, que pode causar efeitos de dependência no paciente. $\mathrm{O}$ estudo de Chiesa et al. (2000), com pacientes com quadro de transtorno de personalidade borderline atendidos com tratamento psicanalítico em hospital ou os resultados do programa Cambridge Sommerville para jovens em conflito com a lei dão evidências de uma relação de dependência entre pacientes e terapeutas.

É claro que uma parte vital do tratamento está justamente no estabelecimento de alguma espécie de vínculo no relacionamento entre paciente e terapeuta, de modo que certo grau de dependência pode estar envolvida no trabalho psicoterapêutico, talvez sendo até mesmo desejável, vez que na aliança entre paciente e terapeuta reside parcela importante do que permitirá que o tratamento produza resultados positivos. Berk \& Parker (2009) fazem este contraponto ao destacar que a transferência é sim um componente importante do tratamento psicodinâmico e é útil para que o terapeuta seja capaz de entender o paciente e para que o paciente possa adquirir insights e melhor compreensão acerca de elementos de sua vida, relações anteriores e sua infância.

Contudo, o risco da transferência é de um poder excessivo conferido ao analista, que passa a ser visto pelo paciente como uma entidade quase onisciente e onipotente, se comparada à fragilidade e insegurança do paciente. Trata-se, assim, de uma discussão acerca do manejo que o terapeuta faz da relação estabelecida com o paciente, ou seja, o domínio que o terapeuta tem ao aplicar sua técnica de trabalho. Neste sentido, podemos aproximar um eventual erro nessa conduta de um erro causado por imperícia por parte do profissional.

Além dos riscos da dependência no curso do tratamento, nos casos de tratamentos de longa duração, em que a relação de transferência teve papel relevante, o término do tratamento pode ser um evento traumático na vida do paciente, resultando 
em efeitos adversos, especialmente para casos em que fatores externos levem a uma interrupção súbita do tratamento.

Outra faceta da dependência destacada pelos autores é o risco de que a terapia se transforme em uma espécie de crescente processo de intelectualização, com um excesso de valorização do intelecto do terapeuta, colocado em um pedestal como referência de sabedoria e boas decisões, incorrendo no risco de que o paciente passe a se orientar pelo modelo intelectual do analista. As consultas terapêuticas podem virar um fim em si mesmo, como um ambiente seguro e descolado do mundo real, substituindo a participação na vida real e em interações com outras pessoas pela realização de um interminável processo de intelectualização abstrata e de alienação no modelo intelectual proposto pelo terapeuta.

Straton (2004) é outro que aborda a questão da dependência e o risco de que o paciente passe a adotar o sistema de crenças ou modelo decisório do terapeuta. Para se referir aos casos de dependência no tratamento psicoterapêutico, Straton utiliza o termo Transtorno de Dependência Iatrogênica (iatrogenic dependency disorder ou IDD). Para ilustrar essa possibilidade, o autor apresenta o caso psicoterapeutas australianos que chegaram a debitar 747 sessões ou até mesmo mais de 900 sessões de um mesmo paciente, no espaço de um ano.

Sobre o risco de que o paciente passe a adotar o modelo de crenças do terapeuta, Straton (2004) utiliza o termo indoctrination, ou seja, casos em que o terapeuta acaba transferindo e de certo modo impondo ao paciente certa doutrina, certo modo de pensar e de encarar a vida. O paciente é iludido, passando a acreditar ou seguir cegamente alguma espécie de crença colocada pelo terapeuta. A ideia geral é de que o sistema de crenças do profissional pode ter impacto no sistema de crenças do paciente, de modo que o paciente se aliena nos modelos apresentados pelo terapeuta, perdendo cada vez mais sua autonomia. No caso das psicoterapias psicanalíticas, pode-se colocar como exemplo também o caso dos alunos que, no curso de sua formação, passam pelo processo de análise, havendo o risco de uma excessiva identificação à posição de analista, com efeitos adversos para o paciente/candidato a analista. 
$\mathrm{Na}$ própria história do movimento psicanalítico podemos retomar o caso do "normal candidate", como apresentado por Gitelson (1954), fator causador de problemas no tratamento. Segundo Kupermann (2012), a figura do "normal candidate" comum no contexto de formação psicanalítica norte-americano de meados do século $\mathrm{XX}$, tinha como característica um candidato a psicanalista com perfil excessivamente "normal", candidatos médicos, jovens, aderidos ao american way of life, sem maiores dificuldades ou conflitos psíquicos, que buscavam a formação psicanalítica pelo prestígio envolvido no cargo. Para Gitelson, o ambiente de formação desses analistas apresentava a psicanálise como algo "correto" e "normal" perante a sociedade, aumentando os efeitos de resistências ego-sintônicas dos candidatos, estabelecendo uma espécie de maneira "psicanaliticamente correta" de como uma pessoa deveria ser. Tais candidatos, cientes dos requisitos para formação em psicanálise se apresentavam, desde o início, adaptados ao que imaginavam que era esperado deles. Para Kupermann: "Conclui-se: o campo psicanalítico havia se tornado superegóico, responsável por uma nova ilusão onde o complexo paterno é atualizado por um modo "psicanaliticamente correto" de ser.". Neste sentido, o próprio modelo de formação de novos psicanalistas, levava a certa imposição de um determinado modelo de crenças, com resultados adversos para os envolvidos.

No mesmo sentido, Bulamah (2014) apresenta a discussão acerca dos homossexuais candidatos a psicanalistas e que, no curso de suas análises didáticas, oprimidos por um sistema de crenças que reprovava, ainda que de modo velado, a formação de analistas homossexuais, eram obrigados a contar histórias falsas de suas vidas, fingindo ser heterossexuais para poderem passar pela formação psicanalítica. Nestes casos, ainda que não haja a identificação ou alienação total do candidato ao modelo de crenças do analista, fica claro que a imposição de um modelo pode também vir a ter consequências adversas sobre o paciente.

Importante destacar que tais ocorrências, de casos de alienação do paciente à pessoa do terapeuta estão frequentemente associadas, na literatura, a casos em que estão envolvidos certos interesses narcísicos por parte do terapeuta, que de algum modo obtém ganhos pessoais ao manter o paciente nessa posição de alienação. Neste sentido, 
podemos pensar que tais casos se aproximam de erros causados por conduta negligente por parte do profissional, ao permitir que seus interesses pessoais se sobreponham aos do paciente e do tratamento.

\section{FATORES CAUSADORES DE EFEITOS IATROGÊNICOS}

No item anterior foram apresentados resultados de estudos que buscam demonstrar os possíveis efeitos adversos dos tratamentos. Nesta segunda parte será apresentado o material encontrado na literatura que aborda a questão dos fatores que, de modo geral, podem contribuir para ocorrência de efeitos adversos no tratamento, ou seja, quais elementos estariam na base da ocorrência de efeitos iatrogênicos. A ideia por trás dessas pesquisas é de que, ao estabelecer um diagnóstico dos elementos potencialmente causadores de iatrogenias, seria possível traçar intervenções que atuassem diretamente nestas causas, reduzindo, assim, os riscos de ocorrência de efeitos adversos.

Esse é também o campo em que são encontradas mais pesquisas sobre o tema das iatrogenias. Também por isso, como mencionado no início do capítulo, os resultados foram agrupados em quatro categorias: aspectos do terapeuta; aspectos do paciente; aspectos da relação estabelecida entre terapeuta e paciente; aspectos incontornáveis da situação social do paciente.

Não será objetivo neste tópico esmiuçar todas as hipóteses encontradas em cada uma dessas categorias. A proposta é de apresentar essas categorias, indicando que modalidades de fatores estariam incluídos em cada uma e indicando trabalhos que fazem uma investigação mais profunda sobre esses temas. 
O primeiro grupo de aspectos que podem impactar o rumo de um tratamento são elementos específicos da pessoa do terapeuta. São numerosos os trabalhos encontrados na literatura sobre esse tema, de modo que, para facilitar e organizar a apresentação dos resultados, será adotada a divisão proposta por Crown (1983), que estabelece duas categorias distintas de características do terapeuta que podem ser prejudiciais ao tratamento. A primeira categoria é aquela que engloba características ou elementos relacionados à personalidade do terapeuta. Já a segunda categoria é aquela que abarca aspectos relacionados com o treinamento e o domínio da técnica apresentados pelo terapeuta. Um aspecto interessante a ser destacado nesse ponto é que, mais uma vez, podemos aproximar essas duas hipóteses dos casos de erro por negligência e de erro por imperícia.

\section{Aspectos da Personalidade do Terapeuta}

Estudo realizado por Wampold \& Brown (2005) produziu evidências de que a pessoa do psicoterapeuta é um fator que afeta mais o sucesso do tratamento do que a aliança terapêutica estabelecida. É claro que variáveis da pessoa do terapeuta terão impacto direto no estabelecimento de um vínculo terapêutico, de modo que tais questões estarão sempre relacionadas, como será visto no item sobre aspectos da relação terapêutica. Porém a ideia aqui é de que as variáveis inerentes ao terapeuta que conduz o atendimento teriam peso especial nessa equação.

Assim, alguns terapeutas seriam simplesmente melhores em facilitar mudanças no paciente, enquanto outros teriam maior tendência a causar prejuízos. Contudo, ainda não é claro no campo das pesquisas que aspectos da pessoa do terapeuta seriam aqueles com maior risco de impacto negativo para o cliente, seja por que diretamente causam prejuízos ou apenas por que impedem uma melhora, muito menos dados que permitam compreender exatamente como acontecem tais processos. Porém, há na literatura uma 
série de trabalhos sobre o tema, que permitem traçar ao menos alguns indicadores sobre quais elementos da personalidade do terapeuta seriam relevantes.

Não é a proposta nesse momento esmiuçar os detalhes de todas as pesquisas sobre o tema, de modo que serão apenas indicados alguns dos elementos listados na literatura como fatores relevantes. De modo geral, esses trabalhos indicam aspectos da personalidade do terapeuta que acabam intervindo no tratamento (narcisismo, baixa autoestima, ressentimento, arrogância, etc.), de modo que o terapeuta recai em erro ao permitir que seus aspectos pessoais acabem por se tornar um obstáculo ao tratamento. Mais uma vez, a noção de negligência. Neste sentido os trabalhos de Bohart (2007); Wolberg (1967); Greenson (1967); Strupp \& Hadley (1985); Castonguay (2010); Henry et al. (1993); Hilliard, Henry \& Strupp (2000); e Crown (1983).

\section{Aspectos Relacionados com o Domínio da Técnica}

A falta de treinamento adequado do terapeuta para manejo da técnica é um problema grave destacado pela literatura, segundo Crown (1983). Afirma que a falta de controle e regulamentação no campo das psicoterapias facilita a presença de falsos terapeutas ou pessoas com pouco treinamento para atuarem livremente, sem maiores preocupações acerca de suas responsabilidades para com o paciente, o que, certamente, poderá ser uma fonte de efeitos adversos.

Assim, os trabalhos relacionando iatrogenia e manejo da técnica busca identificar quais seriam os pontos de erro no manejo da técnica que seriam passíveis de causar iatrogenias. Estamos aqui, mais uma vez, falando de casos de erro por imperícia por parte do profissional. Uma parcela importante destes trabalhos aproxima a ideia de aplicação adequada da técnica com a de manejo adequado da relação terapêutica, de modo que iatrogenias causadas por erro na aplicação da técnica geralmente estão associadas a problemas no estabelecimento ou manejo da relação entre paciente e terapeuta. Outra hipótese destacada são os casos em que o profissional simplesmente não detém o repertório teórico mínimo necessário para que possa sustentar sua prática. 
Mais especificamente, são destacados casos em que falte ao terapeuta base teórica para que possa realizar um diagnóstico adequado dos casos que se apresentam a ele. Neste sentido os trabalhos de Meares \& Hobson (1977); Lieberman, Yalom \& Miles (1973), Crown (1983), Buckley et al. (1981); Greenson (1967); Foa \& Rothbaum (1998); e Strupp \& Hadley (1985).

Para além desses pontos, há ainda outro aspecto mais sensível mencionado na literatura acerca dos potenciais riscos que a relação do terapeuta com a teoria podem causar, e que se localiza na hipótese de terapeutas excessivamente aderidos à sua linha teórica ou técnica terapêutica, seja ela qual for (comportamental, dinâmica, humanista ou outra) e que aplicam sua teoria de modo excessivamente rigoroso e inflexível ou de modo indiscriminado tanto quanto à intensidade quanto frequência das intervenções. Crown (1983) menciona a questão do excesso de rigor do terapeuta ao aplicar determinada técnica, aplicando de modo cego e repetitivo os protocolos e modelos apresentados pela teoria, sem que seja capaz de oferecer maior atenção às características particulares de cada paciente. Trata-se aqui de uma aderência tão grande por parte do profissional ao seu repertório teórico, que lhe fecha a possibilidade de estar aberto para escutar aquilo que é singular de cada atendimento.

Ainda sobre o uso da técnica, a literatura destaca casos em que o momento para aplicação da técnica foi inadequado, podendo causar prejuízos, como no caso do uso de interpretações no tratamento psicanalítico antes do estabelecimento da transferência. Se a tentativa de interpretação for realizada cedo demais ou caso seja "profunda" demais, considerando-se o momento vivido pelo paciente, o resultado pode ser de efeitos prejudiciais para o paciente ou, até mesmo, a interrupção do tratamento. Um exemplo citado por Crown (1983) é o caso do paciente que busca ajuda para disfunção erétil e, logo no primeiro atendimento, recebe uma interpretação de que o problema está relacionado com conflitos homossexuais reprimidos. A ideia aqui é de que o tratamento possui certo tempo e ritmo, ao qual o terapeuta deve estar atento, para que suas intervenções estejam em consonância com o momento do paciente e do tratamento. Essa relação entre efeitos iatrogênicos e o tempo do tratamento pode ser aproximada da noção de erro por imprudência por parte do terapeuta. 
Neste sentido, Freud (1913/1996, pg. 183) já alertava para os riscos envolvidos no uso da interpretação, especialmente caso isso fosse feito no momento inadequado, antes do estabelecimento de uma transferência favorável com o paciente, vez que uma interpretação prematura poderia ativar maiores resistências no paciente, principalmente quando as interpretações são corretas: "Via de regra, o efeito terapêutico será nenhum, mas o desencorajamento do paciente quanto à análise será definitivo.”. E sobre a relação das intervenções como tempo no tratamento: "com freqüência tive ocasião de descobrir que a comunicação prematura de uma solução punha ao tratamento um fim intempestivo"

\section{Aspectos do Paciente}

A segunda categoria de elementos a ser abordada é a dos aspectos relacionados à pessoa do paciente. Desde o início é importante destacar que não se pode incorrer no erro de culpabilizar ou responsabilizar o paciente pelo fracasso de um tratamento, sendo responsabilidade do bom terapeuta empenhar sempre seus melhores esforços para oferecer o melhor tipo possível de cuidado para o paciente, superando desafios que possam se apresentar. Porém, oferecer o melhor cuidado envolve também estar atento para aspectos específicos do paciente que podem influenciar ou até mesmo dificultar o rumo do tratamento. Estando atento a esses obstáculos, o terapeuta poderá atuar para contorná-los e assegurar o melhor andamento possível para o tratamento.

Assim, o que temos em discussão se aproxima bastante da capacidade do terapeuta de realizar um diagnóstico adequado do caso que se apresenta a ele, antecipando aspectos do quadro apresentado pelo paciente e que posam vir a se tornar pontos de resistência ou obstáculo ao tratamento e que, caso não bem manejados, podem resultar em efeitos iatrogênicos ou em interrupção do tratamento. Foa \& Emmelkamp (1983); Strupp (1973); e Strupp \& Hadley (1985), 1985, por exemplo, destacam a falta de motivação por parte do paciente ou falta de desejo de mudança como um importante indicador de risco de fracasso no tratamento, o que também é comprovado por evidências empíricas (Clarkin \& Levy, 2004). 
Outros exemplos mencionados na literatura são casos de pacientes que tem dificuldades em se colocar ou se posicionar ou pacientes com dificuldades de relacionamento interpessoal ou grande resistência para entrar em contato com seus sentimentos, são alguns dos fatores que podem indicar maiores dificuldades de estabelecimento da aliança terapêutica e que, consequentemente, podem representar maiores dificuldades no curso do tratamento.

É destacada também a importância de que o terapeuta possa se questionar e investigar se a modalidade de tratamento que ele tem a oferecer é de fato a mais adequada. Além disso, para além das meras características individuais do paciente há evidências da importância de se considerar a relação entre o tipo de paciente que se apresenta e a modalidade psicoterápica selecionada, de modo que certos pacientes respondem de maneira melhor ou pior conforme o tipo de tratamento utilizado (Beutler et al., 2006).

Essa hipótese é desde cedo levantada por teóricos psicodinâmicos, ao afirmar que certos pacientes talvez não sejam adequados para um tratamento de orientação psicodinâmica, sendo incapaz de sustentar o trabalho que é realizado e sofrendo pioras ao longo do curso do tratamento (Fenichel, 1945). Mesmo em Freud (1913/1996), podemos pensar em suas orientações acerca da importância dos tratamentos de ensaio, onde já se destacava a importância de que fosse considerada logo nas primeiras entrevistas se haveria ou não a possibilidade de continuidade e sucesso do trabalho com determinado paciente.

A partir da literatura teórica e clínica é possível extrair ainda outras características do paciente que, potencialmente, se mostram como obstáculos para o sucesso do tratamento, mas que carecem ainda de maiores estudos como: excesso de apatia por parte do paciente, ego enfraquecido, excesso de traços perversos, paranoicos, psicóticos, masoquistas ou antissociais, nível extremo de dependência e outros.

Importante reforçar, porém, mais uma vez, que mesmo ciente desses dados e das possíveis influências que aspectos do paciente podem ter sobre o tratamento, os terapeutas não devem se deixar levar por motivos irracionais ou resistências pessoais 
que possam prejudicar o tratamento, muito menos culpar o paciente por um eventual fracasso no tratamento, estando sempre disposto a envidar seus melhores esforços na tentativa de cura do paciente Strupp (1973).

\section{Aspectos da Relação entre Terapeuta e Paciente}

O terceiro rol de elementos que podem influenciar negativamente um tratamento é a relação estabelecida terapeuta e paciente, ou seja, a qualidade do vínculo estabelecido entre as partes, que deve se constituir de certa carga emocional adequada, capaz de estabelecer um setting terapêutico e a possibilidade de cura. Nos tópicos anteriores já foram mencionadas algumas questões sobre a importância da relação terapêutica para o tratamento.

Crown (1983), apesar de considerar tais aspectos da relação entre terapeuta e paciente como vitais, afirma também que talvez sejam justamente os mais difíceis de serem investigados. Mas baseados apenas em experiências clínicas, muito antes de ser possível buscar evidências empíricas para isso, psicoterapeutas já sustentavam que uma boa relação com o paciente seria vital para que o tratamento fosse bem sucedido, tanto na história das terapias psicodinâmicas (Fenichel, 1945; Freud, 1913/1996; Greenson, 1967) como nas humanísticas (Rogers, 1961) onde já havia preocupações acerca da possível falta de empatia por parte do terapeuta e seus potenciais efeitos adversos.

Rogers (1961) especulava que a maioria dos casos que terminavam em fracasso poderiam ser explicadas por meio alguma espécie de problema no estabelecimento de uma aliança terapêutica bem sucedida.

Pesquisas empíricas reforçam esse entendimento acerca da importância da relação terapêutica para o sucesso dos tratamentos. Gelso \& Carter (1985) indicam que há muitos estudos que consistentemente demonstram uma correlação entre a qualidade do vínculo estabelecido entre paciente e terapeuta e o grau de melhora alcançado pelo paciente. Esses resultados aparecem em pesquisas que consideram diversas psicoterapias, com abordagens teóricas e modalidades de atendimento variadas e uma 
ampla gama de pacientes. A partir destas pesquisas que evidenciam a importância do vínculo terapêutico para o sucesso do tratamento, pode-se extrair também que um eventual vínculo fraco ou pobre estabelecido entre as partes é uma potencial causa de efeitos adversos e de fracasso do tratamento.

Como visto nos itens anteriores, aspectos do terapeuta, mas também do paciente podem ter influência na qualidade do vínculo terapêutico e, consequentemente, podem ser determinantes para o sucesso ou fracasso do tratamento. Assim, as dificuldades da pessoa do terapeuta ou os obstáculos apresentados pelo paciente, já mencionados nos itens anteriores, podem ter impactos negativos na relação terapêutica e, potencialmente, podem levar à ocorrência de iatrogenias.

A conclusão é de que em qualquer relação terapêutica, aspectos pessoais ou de relacionamento do terapeuta ou do paciente podem afetar o estabelecimento da aliança terapêutica, tanto positiva quanto negativamente, gerando efeitos no sucesso ou fracasso do tratamento e, inclusive, podem potencialmente causar efeitos adversos.

O conhecimento acerca desses riscos levou a recomendações de que especial atenção seja dada à qualidade do vínculo terapêutico que se estabelece com o paciente e a complicações que venham a emergir no curso do tratamento e que possam atrapalhar seu sucesso. A atenção a esses elementos permite que sejam identificados o mais cedo possível, possibilitando que o terapeuta esteja atento para tomar medidas necessária para contornar ou, ao menos, diminuir tais obstáculos.

\section{Aspectos sociais Incontornáveis do Paciente}

A quarta categoria de elementos proposta por Crown (1983) são os aspectos incontornáveis da situação social do paciente. Talvez até por se tratar de aspectos incontornáveis, tais elementos são os que menos recebem atenção da literatura. Por vezes, as pesquisas realizadas deixam de considerar que certos quadros de situação social são tão graves que se torna muito difícil ou até mesmo impossível que um tratamento possa alcançar efeitos positivos. Por exemplo, nos casos de um paciente 
drogadicto inserido em um contexto em que todos ao seu redor também sofrem com adicção ou uma criança que sofre abusos por parte dos pais cotidianamente, são casos em que o tratamento, ainda que bem realizado, dificilmente alcançará sucesso por si só, vez que tais pacientes, após o tratamento, irão retornar para os ambientes hostis que, em grande medida, estão relacionados com a origem de seus sintomas.

Como destaca Crown (1983), é importante que o terapeuta possa estar ciente desses limites, também para estar atento à necessidade de um trabalho em conjunto com outros profissionais, como assistentes sociais, por exemplo, capazes de estabelecer uma rede de apoio que possa dar maior amparo a tais situações sociais, algo que seria muito difícil apenas por meio do tratamento psicoterapêutico.

Com isso se encerra a apresentação desse segundo grupos das possíveis iatrogenias, aquelas causadas por erros do profissional na condução do tratamento e que se articulam aos conceitos de imperícia, negligência e imprudência.

Em seguida, abordaremos rapidamente a terceira categoria adotada neste trabalho que é a das iatrogenias decorrentes das próprias características do tratamento aplicado.

\section{Tratamentos Prejudiciais}

Até então foram abordados elementos que podem eventualmente interferir no curso de tratamentos e causar iatrogenias, como aspectos específicos de um determinado terapeuta ou de um determinado paciente, aspectos da relação entre certo paciente e certo terapeuta, ou aspectos específicos da situação social de alguns pacientes. Foi apresentada também a hipótese de danos causados por terapeutas abusivos que deliberadamente prejudicam seus pacientes.

Contudo, há ainda uma última hipótese de causas de efeitos iatrogênicos levantada pela literatura a ser apresentada. Esta, porém, não varia conforme aspectos de determinado caso ou de determinado terapeuta. Pelo contrário, são os casos de 
tratamentos que por si só, por sua própria especificidade e metodologia de trabalho se mostram prejudicais aos pacientes em geral, ou ao menos a pacientes de um determinado diagnóstico.

Esse tema se mostra mais complicado, pois toca mais diretamente na qualidade, eficácia e riscos de cada tratamento, o que, potencialmente, pode ativar uma série de questões políticas, que vão além do mero âmbito de um tratamento, como, por exemplo, a questão da regulamentação e da proibição de certas práticas terapêuticas. Contudo, neste momento do trabalho, o foco é de apresentar apenas um breve panorama acerca das pesquisas sobre tratamentos possivelmente adversos, sem adentrar ainda a questão das possíveis soluções para este problema, algo que será trabalhado em capítulo posterior.

O principal trabalho precursor sobre o tema é o realizado por Lilienfeld (2007), tomado como principal referência sobre esse tema. Lilienfeld se propôs a realizar um levantamento das pesquisas já existentes na literatura que indicam potenciais efeitos adversos de algumas modalidades de psicoterapia. A partir da análise do material coletado, o autor elabora uma lista de tratamentos que, segundo evidências empíricas, podem potencialmente fazer mal ao paciente. A lista foi dividida em dois grupos: o primeiro é de grupos que provavelmente são perigosos para os pacientes e o segundo grupo é o dos tratamentos possivelmente perigosos para o paciente.

A ideia da pesquisa é de que tal lista possa ser um trabalho em aberto, sendo constantemente atualizada e complementada, conforme os avanços das pesquisas empíricas, podendo servir como um guia para orientar os pacientes acerca da escolha de tratamento e, até mesmo, indicar às autoridades quais tratamentos devem ser regulamentados ou até mesmo banidos. Além disso, tal pesquisa poderia ajudar na identificação de fatores comuns causadores de danos numa diversidade de modalidades terapêuticas.

A lista inicial proposta por Lilienfeld inclui um total de doze modalidades terapêuticas, sendo dez provavelmente prejudiciais para alguns indivíduos e duas possivelmente prejudiciais para alguns indivíduos. Dentre os provavelmente prejudiciais 
estão: scared straight interventions; critical incident debriefing; facilitated communication; attachment therapies (rebirthing); recovered-memories techniques; DID-oriented therapy; grief counseling para indivíduos com reações normais de luto; expressive-experimental therapies; boot-camp interventions para jovens transgressores; e DARE programs. Já os tratamentos possivelmente prejudiciais incluem: peer-group interventions para jovens transgressores; e relaxation treatments for panic-prone patients.

Não cabe nesse trabalho esmiuçar os detalhes das pesquisas envolvendo cada uma dessas modalidades terapêuticas, bastando a referência ao trabalho de Lilienfeld para um maior aprofundamento sobre o tema. Estudos posteriores tem buscado contribuir para inclusão de novos tratamentos nessa lista. De modo geral, tais tratamentos demonstraram sua ineficácia em melhorar os sintomas que se propunham a tratar (scared straight interventions) ou, então, causavam pior dos sintomas (critical incident debriefing) ou, ainda, surgimento de novos sintomas (peer-group interventions para jovens transgressores).

O importante a se extrair aqui é a noção de que podem existir certas modalidades terapêuticas que, em si mesmas, apresentam alta possibilidade de efeitos adversos para os pacientes, sendo contraindicadas para determinados casos ou devendo ser usadas apenas em casos excepcionais e com grande cautela.

Além disso, extraímos daqui a hipótese de que mesmo um tratamento conduzido de modo adequado pelo profissional pode ainda assim ser produtor de efeitos iatrogênicos. Relembrando aqui a ideia de que todo tratamento capaz de produzir efeitos de cura tem também o poder para produzir efeitos iatrogênicos.

Vimos então que a literatura sobre o tema da iatrogenia oferece alguns indicadores acerca do que seriam efeitos iatrogênicos e quais seriam seus elementos causadores. Porém, na grande maioria, essas pesquisas foram realizadas no campo da psicoterapia, colocando-se a questão se tais resultados poderiam ser transpostos e aplicados ao campo da psicanálise. No capítulo seguinte, então, será debatida justamente esta diferenciação entre psicanálise e psicoterapia e de que modo isso pode 
ser relacionado ao tema das iatrogenias. Desse modo entramos também na segunda parte do trabalho, que visa abordar especificamente o tema da iatrogenia na psicanálise. 


\section{Capítulo 5 - IAtrogenia e Poder: DA Psicoterapia À PSicANálise}

No capítulo anterior foram apresentados os principais resultados das pesquisas sobre os possíveis efeitos iatrogênicos no campo das psicoterapias. Elementos como as características individuais de cada paciente ou de cada analista, características de determinados casos clínicos, excesso de rigor no uso da técnica, a relação estabelecida entre terapeuta e paciente, são alguns dos índices apontados pela literatura como possíveis causadores de iatrogenias no curso de um tratamento psicoterápico.

Contudo, poucas são as pesquisas que abordaram especificamente o tema da iatrogenia no curso de um tratamento psicanalítico, levantando a questão sobre se tais resultados seriam ou não aplicáveis também ao tratamento psicanalítico. Se o objetivo desta pesquisa é de abordar o potencial iatrogênico do tratamento psicanalítico, há de se discutir, primeiramente, de que modo se pode pensar a distinção entre psicoterapia e psicanálise, buscando identificar a especificidade do tratamento psicanalítico para que, a partir disso, possam ser considerados os potenciais riscos iatrogênicos envolvidos no curso de um tratamento psicanalítico.

Nesse sentido, tanto as psicoterapias quanto a psicanálise, enquanto modalidades de "talking cure" não estão isentas de tentar compreender, cada uma no âmbito de sua própria prática, quais aspectos de sua prática configuram-se como pharmakons disponíveis em sua farmácia para serem ministrados ao paciente, quais ferramentas estão à disposição para condução de um tratamento, o modo como serão utilizadas e os efeitos que poderão causar, em benefício ou prejuízo ao paciente. Em outras palavras, trata-se de saber qual o campo e função dos poderes da fala e da linguagem, da escuta e da presença do psicoterapeuta ou do psicanalista, como princípios de seu poder de transformação e cura ou de iatrogenia no curso de um tratamento.

Como já visto, no campo da psicanálise, as pesquisas que abordam diretamente o termo "iatrogenia" são raras (Berk \& Parker, 2009). Entretanto, apesar da falta de 
pesquisas, é possível reconhecer na literatura psicanalítica a dispersão deste tema em conceitos outros como contratransferência, acting out, regressão, passagem ao ato, reação terapêutica negativa, sintoma transitório, neurose de transferência, etc. Portanto, sobre o conceito de iatrogenia pode-se identificar uma miríade de situações clínicas de avanço, erro e impasses articulados ao próprio progresso da teoria psicanalítica, sem que contudo fosse realizado um esforço unificado e concentrado no sentido de identificar e sistematizar os possíveis riscos do tratamento psicanalítico ao paciente e eventuais mecanismos possíveis para redução destes riscos.

Ao longo da história da Psicanálise, podemos resgatar alguns casos em que os efeitos negativos da atuação do psicanalista vieram à tona. Freud (Freud 1905/1996) mesmo já foi capaz de reconhecer os efeitos e limites de suas intervenções. $\mathrm{O}$ caso princeps foi o caso Dora, cujo apontamento dos limites de sua intervenção se daria no reconhecimento tardio - quase 20 anos depois - de sua transferência homoerótica.

Em outro exemplo, anos mais tarde, também Lacan (1958/1998, pg. 604) em seu texto A Direção do Tratamento e os princípios de seu poder faz referência ao caso apresentado por Ernest Kris, conhecido como "O homem dos miolos frescos", para tecer uma crítica aos efeitos do tratamento conduzido de acordo com a metodologia dos pósfreudianos que utilizavam a chamada Psicologia do Ego.

Ainda mais recentemente, no cenário brasileiro, durante o período de vigência da ditadura militar, o caso de Amílcar Lobo, psicanalista e tenente do exército que participou de sessões de tortura, atestou os níveis extremos a que pode chegar o abuso do poder por parte de um psicanalista ${ }^{6}$.

\footnotetext{
6 Amílcar Lobo Moreira da Silva foi um médico psicanalista, segundo-tenente médico do exército, serviu no $1^{\circ}$ Batalhão de Polícia do Exército e no Destacamento de Operações de Informação - Centro de Operações de Defesa Interna (DOI-CODI) do Rio de Janeiro (1970-1974), um dos mais severos centros de tortura do país. Cursava também formação em Psicanálise na Sociedade Psicanalítica do Rio de Janeiro (SPRJ). Durante o período da ditadura, era convocado para participar de sessões de torturas realizadas em presos políticos, como parte do processo de repressão militar contra integrantes da luta armada contra a ditadura. Sua função nessas sessões, enquanto médico e psicanalista, era de identificar se o preso ainda estaria em condições de ser submetido à mais torturas. Mesmo após denúncias feitas contra Amilcar Lobo, no âmbito da SPRJ, passou-se um longo tempo até seu descredenciamento da sociedade psicanalítica, sendo necessária, inclusive, intervenção por parte da Associação Psicanalítica Internacional (IPA). (Moreira, 2014)
} 
É sabido que a psicanálise ela mesma possui ao menos um efeito iatrogênico, ou colateral, pois onde Freud queria eliminar uma neurose, viu emergir como efeito deste trabalho uma nova neurose: a neurose de transferência. Porém, encontrar alguma espécie de consenso acerca da existência de outras possibilidades de iatrogenias ou mesmo quais seriam os critérios para que um fenômeno possa ser considerado uma iatrogenia no curso do tratamento é tarefa árdua, em especial quando se adota uma metodologia de pesquisa que reduz o tratamento apenas à sua dimensão de método terapêutico, como visto no capítulo anterior, com as pesquisas realizadas no campo da psicoterapia.

Tais pesquisas deixam de lado uma discussão mais profunda sobre os aspectos éticos envolvidos no tratamento, as relações de assimetria e poder entre paciente e terapeuta e também considerações acerca do que é sofrimento vivido por um sujeito que busca o tratamento. Discussões que seriam capazes de nos fornecer outros parâmetros acerca do que poderia ser considerado iatrogênico, uma vez que o sofrimento é dependente de uma narrativa ligada a uma gramática social, a um modo que é mais ou menos reconhecido no terreno intersubjetivo e que convoca o terapeuta ou psicanalista a se posicionar eticamente diante desta narrativa de sofrimento e a decidir como irá se posicionar diante dos efeitos que suas intervenções podem ter sobre o sujeito que o procura.

O material que emerge na situação clínica vai ser trabalhado por cada profissional conforme certas escolhas fundamentais, a partir da linha teórica de sua preferência, mas que podem parecer o máximo de arbitrariedade ou falta de rigor aos adeptos de outro sistema conceitual. Se por um lado Mezan (2002) nos indica que a diferença entre uma corrente teórica e outra está na teoria e nas habilidades que cada corrente oferece aos seus adeptos para que possam descrever, aprofundar, compreender e solucionar certos fenômenos da clínica sobre os quais terão que se posicionar, por outro lado é importante questionar também o modo como cada corrente teórica se posiciona eticamente, acerca dos possíveis efeitos de suas intervenções e a relação destas intervenções com o sofrimento trazido pelo paciente. Nesse ponto, há o objetivo de evitar que eventuais efeitos nocivos do tratamento sejam absorvidos por uma 
dinâmica que justifica seus meios aos seus fins, reduzindo o processo terapêutico à mera aplicação de técnicas visando à eliminação de sintomas, sendo essa a única medida de sucesso ou fracasso para o tratamento.

A hipótese a ser explorada nesse capítulo é de tomar o poder como chave para entendimento da iatrogenia, apontando que se nessa relação assimétrica que se estabelece entre terapeuta e paciente no curso de um tratamento podemos localizar os princípios do poder que embasam o tratamento, podemos considerar também que o (mal) uso dessa relação de poder pode resultar em nocivos efeitos iatrogênicos para o paciente. De modo mais específico, seria possível identificar casos em que opera uma perda de liberdade do paciente, que se faz ouvir nessa relação de poder e que pode ser reconhecida a partir da narrativa de sofrimento apresentada pelo paciente e o modo como tal narrativa será escutada pelo analista. Pois se um psicanalista fez seu percurso de análise pessoal, podendo reconhecer seu próprio sofrimento, é importante que possa também ser capaz de não tomar como regra seu próprio "modelo de sofrimento", estando aberto ao reconhecimento das narrativas singulares de sofrimento de seus pacientes.

Outro problema que emerge é que certas formas de sofrimento não se transformam em narrativa! Assim, há de questionar se o que ainda não se transformou em clara narrativa de sofrimento pode estar sob o julgo do que não foi ainda reconhecido.

Dizemos isso pois, como vimos, um ponto importante levantado por Berk \& Parker (2009) refere-se a certa crença entre os profissionais de que um terapeuta ruim, ineficaz ou explorador, naturalmente perderia todos seus pacientes com o passar do tempo, pararia de receber indicações e, aos poucos seria excluído de sua atividade, vez que os pacientes se recusariam a retornar a um profissional inadequado, reduzindo a possibilidade de ocorrência de algum efeito adverso. Uma espécie de "seleção natural" dentre os profissionais em atividade.

Contudo, segundo os autores, isso não é o que mostra a prática clínica. Há pacientes que mesmo em casos de tratamento ineficaz ou prejudicial optam por 
continuar o tratamento, seja por que aos poucos se adaptam ao terapeuta abusivo, caso não ocorra nenhuma ofensa muito grave, seja porque não identificam que o curso do tratamento oferecido não é o mais adequado. E enquanto isso o quadro do paciente vai se deteriorando, sem que o paciente consiga identificar o próprio tratamento como causador de sofrimento, com claros efeitos iatrogênicos para o paciente. Seria o caso do paciente que transfere ao analista o poder da significação acerca de sua própria narrativa de sofrimento e de sua própria demanda. O resultado pode ser uma dependência do paciente ao tratamento e ao terapeuta, tendo ganhos secundários com as sessões, enquanto sua condição se agrava.

Em casos como esse, fica evidente que uma situação terapêutica, calcada numa relação assimétrica, é uma situação de poder. E a psicanálise nos faz reconhecer que nem toda relação de submissão ou com a presença sintomática gera uma narrativa de sofrimento e, consequentemente uma demanda de sua eliminação. Um modo claro de apontar isso em psicanálise, já em Freud, é que nesses casos teríamos uma situação de repetição na transferência do infantil do sujeito que demanda uma autoridade que legisle sobre si. Se há possibilidade de que o sujeito, mesmo reconhecendo que sofre, não abandone seu terapeuta, é porque este dá a ele o poder de decidir acerca de seu destino. Nenhum psicanalista ou psicoterapeuta pode se furtar a pensar sobre a posição de mestria que sua posição no dispositivo de tratamento lhe confere.

Castonguay (2010) destaca a importância de que os terapeutas possam, independentemente de linha teórica ou abordagem, por mais doloroso que seja, reconhecer que é muito provável que todos tenham, em algum ponto de suas carreiras, causado danos a um ou mais pacientes: Assim, em que pesem as divergências entre as diversas teorias psicoterápicas e psicanalíticas, nenhuma delas pode afinal se furtar ao problema prático de tentar compreender quando algo não dá certo e o que operou que teve como resultado um efeito iatrogênico. Mas mais que isso: importante questionar não apenas os efeitos iatrogênicos mais evidentes, mas aqueles cujos modos de operação e efeitos são silenciosos, que guardam no seu interior uma relação de alienação do paciente à pessoa do analista, ponto que se apresenta como chave de leitura 
para o problema da iatrogenia, passando do poder da iatrogenia à iatrogenia do poder do terapeuta.

Se tomarmos as propostas de Bergin (1970) e de Balint (1957), de que todo tratamento capaz de gerar efeitos de tratamento, traz em si também o risco de efeitos nocivos ao paciente, podemos entender que o reconhecimento do fracasso, dos limites de uma práxis, está ligado proporcionalmente ao reconhecimento dos limites de seu poder e dos mecanismos que operam na cura. De onde afinal cada tratamento retira a sua eficácia? Se confiamos numa especificidade da prática psicanalítica que a distingue de outras modalidades de tratamento, como tal distinção se reflete nos possíveis riscos iatrogênicos do tratamento psicanalítico?

Como podemos, então, pensar a iatrogenia no âmbito da psicanálise, de um modo que não se limite apenas a mensurar o grau de sucesso ou insucesso na eliminação de sintomas, como visto nas pesquisas sobre as psicoterapias, mas que possa implicar os próprios mecanismos de poder em jogo no curso de tratamento e que the conferem também sua eficácia? Em que medida isso pode ser relacionado à distinção entre as psicoterapias e psicanálise?

Faz-se necessário então, em um primeiro momento, buscar uma melhor diferenciação entre a psicanálise e as psicoterapias para que, posteriormente, tendo localizado a especificidade da prática psicanalítica, seja possível avançar em considerações acerca dos potenciais riscos e efeitos iatrogênicos envolvidos no tratamento.

\section{A IATROGENIA NA DISTINÇÃo ENTRE PSICOTERAPIAS E PSICANÁLISE}

Maleval (2005) aborda a questão das diferentes denominações que compõem o chamado "campo psi": psiquiatras, psicanalistas, psicólogos, psicoterapeutas. Categorias que se confundem dentro desse campo, sendo difícil traçar limites claros que permitam distingui-los. Tal confusão se faz presente para os profissionais do campo, em sua dificuldade para se situar e se diferenciar de outras práticas; para os pacientes que 
não têm familiaridade com as diversas categorias o que lhes causa confusão, no momento de buscar um tratamento; e, por fim, para os políticos e legisladores, quando emerge a questão da regulamentação sobre o campo psi. Colabora para esta confusão o grande aumento na oferta de diversas psicoterapias, especialmente após a Segunda Guerra Mundial, de modo que mesmo a distinção clássica entre psicoterapia e psicanálise se torna embaçada.

Maleval (2005) propõe a existência de dois modos possíveis de compreensão e organização desse campo psi que se apresentam na literatura sobre o tema. O primeiro modo é compreendê-lo a partir das técnicas utilizadas, buscando conter o campo numa grande teoria da influência. O segundo modo é de caracterizar o campo a partir dos usuários, das demandas de psicoterapia que são endereçadas aos profissionais.

A primeira tese é a defendida por autores como Nathan (1998, 2001), afirmando que tanto psicoterapias quanto psicanálise seriam apenas diferentes modalidades ou graus de aplicação da influência ou de técnicas de sugestão. Porém, usando apenas este parâmetro, seria difícil distinguir o campo psi da publicidade ou da tortura, sendo necessário adicionar um segundo elemento: a terapêutica. Tal abordagem apresenta problemas, como apontado por Maleval (2005), pois toma o paciente como um objeto plástico, a ser moldado e manipulado por meio da influência, e não como um sujeito dotado de singularidade. Além disso, é difícil sustentar uma unidade do campo psi, a partir de um critério que sequer é aceito por boa parte dos profissionais como elemento de sua prática.

Já a segunda tese se faz mais presente entre os políticos que visam à regulamentação do campo e que, para tanto, tendem a concebê-lo a partir das demanda de psicoterapia. Sob o argumento de que pretendem proteger - por meio da legislação aqueles que demandam psicoterapia, se esforçam para traçar limites entre seitas e charlatães de um lado, e a medicina e a ciência de outro. Uma análise da demanda de psicoterapia mostra a ocorrência de um amplo crescimento, endereçada principalmente a quatro profissões principais (psiquiatria, psicologia, psicoterapia e psicanálise), fenômeno que confere ao campo sua consistência política e social. 
Dada a proximidade e consistência desse campo, a própria possibilidade de se delimitar qualquer dessas profissões, discernindo a especificidade de sua formação e prática em relação às outras, passa necessariamente pelo contato e definição dos limites com as outras práticas do campo psi.

Retomando a proposta de Nathan, a partir do estudo das psicoterapias tradicionais, o autor coloca a influência como princípio motor das psicoterapias em geral, permitindo que seja construída uma teoria geral das psicoterapias, pautada por uma postura autoritária de influência, em que o tratamento se define pela violência: "Tratamento é sempre um ato de pura violência contra a ordem do universo. E nenhuma terapêutica é mais violenta do que aquela que pretende tratar a alma" (Nathan, 1998, pg. 11), de tal modo que até mesmo o estudo das técnicas de tortura poderia ser útil para as psicoterapias, vez que para Nathan "torturar é, antes de tudo, saber modificar o outro".

A proposta de Nathan possui certa elegância, pois se alinha com dados obtidos em pesquisas clínicas que indicam a equivalência de eficácia entre as diversas abordagens, sendo possível concluir que as diversas teorias seriam apenas ferramentas auxiliares, mas orientadas por um único princípio básico: a influência.

Na proposta Nathaniana, a influência deve ser entendida como o uso de um saber que permita tecnicizar a relação terapêutica, por meio do uso da sugestão. Assim, a prática clínica se reduz, se limita à aplicação de uma técnica e as psicoterapias seriam então técnicas de sugestão aplicadas sobre um sujeito plástico e maleável. Assim, Nathan (1998) insiste que a influência terapêutica consiste no uso da influência visando à modificação do núcleo de uma pessoa, com um objetivo de cura.

Não há dúvida de que um dos fatores comuns das psicoterapias é o uso da sugestão que confere ao tratamento seu poder. Tal sugestão, porém, não se confunde com o exacerbado alcance conferido por Nathan à sua noção de influência terapêutica capaz de modificar diretamente o paciente, tal qual um objeto plástico. A experiência mostra que mesmo na aplicação das psicoterapias mais puras, como por exemplo a hipnose, mesmo quando aplicada aos sujeitos mais hipnotizáveis, ainda assim 
apresentam-se limites ao poder da sugestão, localizados nos fantasmas e resistências singulares de cada paciente.

Numa abordagem Nathaniana que confere pleno poder à influência terapêutica, tudo se reduz à aplicação adequada das técnicas de influência, levando à conclusão extrema de que a pessoa do terapeuta ou seu encontro com um determinado paciente não teriam efeitos singulares para o tratamento que se inicia. A importância toda estaria centrada exclusivamente na teoria e no aparelho institucional que o terapeuta representa (Nathan, 1998). Neste sentido, estimula a proliferação de técnicas autoritárias utilizadas por algumas psicoterapias, colocando a psicoterapia como processo de assujeitamento ao Outro e, com o avanço do tratamento, uma verdadeira sistematização deste assujeitamento, processo que pode acarretar sérios riscos para o paciente.

Considerando as origens das psicoterapias na hipnose, ou mesmo técnicas mais modernas como a psicoterapia "de base" ou a Terapia Cognitivo-Comportamental (TCC), há sentido em afirmar que a psicoterapia é fundamentalmente violência exercida por meio do uso de técnicas autoritárias. Pautado nas psicoterapias tradicionais, Nathan se faz teórico e defensor da psicoterapia autoritária, com uma rejeição da subjetividade, estimulando práticas autoritárias e se aproximando dos que reduzem as psicoterapias a uma teoria da aprendizagem. Tal compreensão, porém, apesar de deter certa pertinência em relação a algumas das práticas psicoterapêuticas, falha ao deixar de considerar a especificidade de outras práticas que escapam a esse entendimento. Em particular a psicanálise e as psicoterapias relacionais que ganham força, principalmente após a Segunda Guerra Mundial.

Se inicialmente, com Freud, a divisão entre psicanálise e psicoterapia se mostrava mais clara, a partir da oposição entre uma intenção de neutralidade prevista para a psicanálise e uma orientação persuasiva presente nas psicoterapias, com o passar do tempo e o crescente sucesso da psicanálise, esse cenário se modifica. Na década de 50 a psicanálise chega aos EUA e se difunde, dando origem também às novas correntes psicoterapêuticas que visam romper com suas origens na hipnose. 
Neste movimento, podemos mencionar o surgimento da obra de Carl Rogers, que parte da psicanálise e de certa decepção com seus preceitos, para realizar uma junção ao humanismo cristão, para desenvolver uma nova modalidade de psicoterapia dita "não diretiva", em que era incorporada a neutralidade do terapeuta proposta por Freud, de modo que o terapeuta não se coloca na posição de mestre. Orientados por uma confiança no ser humano, como um ser naturalmente positivo, socializado, racional e realista, que tende a seguir em frente, tendendo sempre ao crescimento, cabe ao terapeuta oferecer uma compreensão empática ao paciente, a partir do próprio quadro de referência interna do paciente, de modo a possibilitar a liberação de uma gama de forças poderosas de cura e mudança. Assim, se por um lado se adota a neutralidade advinda da psicanálise, por outro lado são deixados de lados aspectos relativos à vida pulsional e ao inconsciente. Contudo, tal confiança no ser humano e em sua capacidade de evolução se mostra incompatível com práticas autoritárias como a hipnose, por exemplo. Entra em jogo também a importância do terapeuta para o tratamento, como alguém que também é influenciado e modificado pelos tratamentos que conduz. Tal abordagem se expande e alcança êxito ao longo da década de 60.

Posteriormente, já na década de 70, nascem as psicoterapias chamadas relacionais, que retomam aspectos da psicanálise para propor uma modalidade de tratamento que coloca como característica central uma grande prudência por parte do psicoterapeuta em relação aos seus poderes de sugestão durante o tratamento. Mais uma vez, há um rompimento com os preceitos autoritários advindos das psicoterapias, abandonando-se a ideia do paciente como objeto plástico a ser manuseado, passando a propor que se opere um trabalho conjunto, que permita ao paciente uma mudança, a partir de sua relação com o terapeuta. Aqui também entram em cena os efeitos do curso da terapia sobre o próprio terapeuta, que também é influenciado pelo paciente, em oposição ao mestre das teorias autoritárias que permaneceria sempre inabalado. São apresentados e adotados conceitos novos como: empatia, colaboração e aliança.

Ainda na década de 70, as terapias relacionais se expandem, inseridas num quadro maior das psicoterapias ditas humanistas, especialmente na Califórnia na década de 70 . Tomam como ponto em comum a crença num sujeito que tende naturalmente à 
evolução e melhoria, ruma à saúde e auto realização, bastando para isso que lhe sejam oferecidas condições mínimas para que possa evoluir. Partilhando desse otimismo em relação a seus pacientes, tais psicoterapias não se entendem como técnicas autoritárias ou diretivas. Pelo contrário, defendem o projeto de um tratamento que vise propiciar ao paciente um processo de mudança, dentro de uma dinâmica própria a cada sujeito e a partir da interação com o próprio terapeuta, também implicado no tratamento.

Assim, na década de 70, ganha força certa cisão no campo das psicoterapias, opondo, de um lado, as psicoterapias autoritárias que mantinham o compartilhamento de preceitos advindos de sua origem na hipnose e, por outro lado, psicoterapias pautadas pelas noções de neutralidade e de implicação da experiência pessoal entre terapeuta e paciente. Em contrapartida, tal movimento gera preocupações por parte dos psicanalistas, que tendem a criticar o modo como tais abordagens passam a se apropriar de certos conceitos da psicanálise, mas utilizando-os fora do contexto da teoria psicanalítica, o que teria como efeitos grandes mudanças no seu sentido e valor, podendo representar um uso indevido e até perigoso destes conceitos.

Psicanalistas da IPA como Brusset (1991, pg. 565) constatam que: "práticas empíricas da experiência imemorial da psicoterapia basearam-se na teoria e encontraram legitimidade, senão legalidade, na técnica, portanto, na teoria psicanalítica, ao preço de remanejamentos que mudaram o sentido e o seu significado".

Tal movimento teve como efeito principal uma crescente influência recíproca entre psicanálise e psicoterapia, crescente ao longo dos anos e que se estende até os dias atuais, resultando em certo embaçamento da linha divisória entre psicoterapia e psicanálise, de tal modo que, hoje em dia, é difícil estabelecer com clareza a distinção entre certas práticas psicanalíticas aplicadas à terapêutica e psicoterapias ditas psicanalíticas, que integram práticas dos dois campos de saber, visando uma prática unificada.

Diante deste movimento, vemos que a proposta Nathaniana de utilizar o uso feito da influência ou da sugestão como critério para diferenciação no campo psi se torna problemática. Especialmente, para distinção entre os campos da psicoterapia e da 
psicanálise, tal critério apresenta suas limitações principalmente quando consideramos certas psicanálises pós-freudianas que propõe como um dos objetivos ou fins do tratamento a identificação do paciente ao ego forte do analista. Tal objetivo promove a reaparição de tendências autoritárias no seio da psicanálise. Já em 1958, Lacan (1958/1998, pg. 171) aponta para o risco de um retorno de "surpreendentes mistificações da psicoterapia autoritária".

Além do objetivo de identificação do paciente ao ego forte do analista, tais psicanálises se apropriam também da noção de empatia advinda das psicoterapias, integrando-a a seu corpo teórico para propor um protagonismo da contratransferência no curso do tratamento, deixando de ser considerada como um fator de resistência, para ser utilizada ativamente como aspecto dinâmico no curso do tratamento. Já a partir de Ferenczi se fazia presente a ideia do uso da subjetividade do analista como ferramenta útil ao tratamento, uma empatia do analista, para que fosse capaz de colocar-se no lugar do paciente e "entrar naquilo que ele sente" (Ferenczi, 1920-1933/2000, pg. 372).

Ao longo da década de 50, com autores como Heinrich Racker e Paula Heimann, avançam as teorias com base na contratransferência, a partir da influência de técnicas advindas das psicoterapias. Já na década de 60, a contratransferência se impõe um dos principais instrumentos para condução de um tratamento, principalmente no âmbito da psicanálise norte-americana, influenciada pelos avanços da terapia humanista californiana.

Tal movimento de aproximação da psicanálise às práticas psicoterapêuticas encontra campo fértil no âmbito da IPA, proliferando-se a pesquisa visando práticas intermediárias entre a psicanálise e a psicoterapia. Tal movimento é reflexo também de uma redução na quantidade de pacientes passíveis de serem submetidos ao "tratamento típico", seja pela dificuldade em manter uma regularidade de cinco sessões semanais (modelo que vigorava a época), seja pela própria não indicação do tratamento para o caso. Como tentativa de solução tivemos a expansão da categoria dos psicoterapeutas psicanalíticos, situados numa zona intermediária entre os dois campos, e estimulados pelas pesquisas realizadas na IPA. Chega-se ao ponto de considerar que a própria distinção entre psicanálise e psicoterapia psicanalítica não seria mais pertinente. 
Wallerstein (2001, pg. 88), após uma pesquisa de 30 anos, atesta essa aproximação que reduz a distinção entre os dois campos a uma mera diferença de graus:

"a inevitável incorporação e a infiltração das técnicas ditas de apoio, mesmo onde há esforço em aplicar com a maior pureza a psicanálise propriamente dita e, inversamente, a infiltração das intervenções baseadas na expressão de abordagens terapêuticas superficiais firmemente centradas no apoio. Vivemos ou pelo menos eu vivo hoje em dia, com abordagens técnicas contínuas, com intervenções diferentes, com interpretações mais expressivas àquelas mais abertamente centradas no apoio e propostas com maior flexibilidade levando em consideração as exigências clínicas momentaneamente mutáveis do paciente"

Especialmente no interior da IPA, a técnica psicanalítica evolui no sentido de uma aproximação crescente com as psicoterapias, aumentando também a importância dada à contratransferência e à pessoa do analista para o rumo do tratamento. Autores como Ogden e Renik defendem esta abordagem interpessoal e a implicação da subjetividade do analista no tratamento psicanalítico, apagando diferenças entre psicanálise e psicoterapia. Em Renik chegamos a encontrar a afirmação de que à psicanálise não caberiam objetivos outros que não a terapêutica, não sendo necessária a distinção entre os dois campos, de modo que "um tratamento que obtém o benefício terapêutico esperado pelo paciente em apenas uma sessão, constitui uma autêntica psicanálise" (Renik, 2001, pg. 229).

Há uma expansão em categorias como a de psicoterapias psicanalíticas, nas quais seria necessário limitar a regressão libidinal ou a profundidade das interpretações, não efetuando a análise da transferência e tendo como foco de trabalho as defesas do Eu a partir do estabelecimento de uma "aliança terapêutica" entre terapeuta e paciente, tendo como objetivo central a ideia de cura e eliminação dos sintomas, mediante interpretações que conferem sentido ao paciente e que permitem, ao final, a identificação do paciente ao ego forte do analista. Defendem que a psicanálise está inserida no campo das psicoterapias, de modo que o próprio Freud teria, no mais das 
vezes, praticado nada mais do que uma psicoterapia (Cournut, 1998). Para Maleval (2004, pg. 46):

"Com isso, da psicoterapia à psicanálise, não existe mais nada para a IPA senão uma sutil diferença de graus, o que leva a fazer da primeira uma psicanálise amputada e a promover o tratamentopadrão ao nível de acabamento da psicoterapia."

A partir desse movimento, é mais fácil compreender a proposta Nathaniana mencionada inicialmente, de incluir todas as práticas terapêuticas sobre o conceito único de influência ou, em suas palavras: "englobar no termo 'psicoterapia' qualquer procedimento de influência destinado a modificar radicalmente, profundamente e duradouramente uma pessoa, uma família ou simplesmente uma situação, e isso a partir de uma intenção terapêutica." (Nathan, 1998, pg. 12). Afirma que seria possível equiparar e englobar nesse mesmo plano tanto as psicoterapias científicas, enquanto práticas legítimas, eficazes e interessantes, quanto as terapias clássicas, as novas formações terapêuticas de inspiração religiosa, vez que, em tese, todas estariam equiparadas por sua eficácia terapêutica pautada na influência. Neste sentido, Nathan (1994, pg. 95) afirma: "Se, de fato, a técnica psicanalítica é eficaz - e sei que o é -, devemos concluir disso que a psicanálise é evidentemente comparável às outras técnicas de influência e naturalmente, dentre elas, às outras terapêuticas tradicionais."

Desse modo, com uma prática voltada quase que exclusivamente para eficácia terapêutica, questões teóricas, epistemológicas ou diagnósticas acabam sendo relegadas a um segundo plano, para que se possa focar exclusivamente na elaboração de uma prática multiuso, aplicável a qualquer pessoa, visando à eliminação do sintoma, sem maiores preocupações com a diagnóstica e a nosografia ou a preocupação em entender o funcionamento do sujeito para além do mínimo necessário para elaboração de um método de cuidado eficaz.

Em busca dessa máxima eficácia terapêutica, há o aparecimento da abordagem chamada de psicoterapia integrativa, plural ou complexa, pautada pelo consenso acerca da equivalência de eficácia entre as diversas técnicas, professando que o terapeuta deve 
ser apto a dominar e aplicar o maior número de técnicas possíveis, podendo alterar a técnica usada conforme as necessidades do paciente, ou mesmo combinar técnicas no curso de um mesmo tratamento ou alternar entre uma e outra técnica, partindo da premissa de que nenhuma forma de psicoterapia é eficaz sempre, cabendo ao terapeuta julgar qual a melhor para cada caso.

Assim, as bases epistemológicas e aspectos teóricos de cada teoria seriam secundários, com um ecletismo técnico que se apropria de métodos de diversas fontes, sem, contudo, carregar também as infraestruturas éticas e epistemológicas de cada uma (Maleval, 2004, pg. 51).

É fácil deduzir os problemas que emergem de uma proposta como essa: como discernir quando a psicoterapia integrativa é aplicável e quais seriam os critérios para sustentar as alterações de uma para outra técnica? Qual deve ser o critério a balizar tais mudanças, sendo que se perderam as bases epistemológicas dessas técnicas? Como fixar os limites de uma prática sem teorizá-la com mais rigor?

A partir destes problemas, surge, em paralelo à psicoterapia integrativa, o uso de parâmetros temerários como a "sensibilidade" do analista, ou a leitura feita de cada caso, sem que sejam apresentados parâmetros para tanto. Haveria uma eficácia inerente ao mero processo de permitir que o paciente fale ou relate sua história para o terapeuta, sendo apenas o caso de encontrar a teoria mais adequada para propiciar isso, reduzindo até mesmo a importância dada à própria sugestão e às possibilidades de intervir no relato e modificá-lo. A partir dessa linha de raciocínio integrativa, poder-se-ia considerar até mesmo a inserção de técnicas como o uso de psicoelétrico reeducativo ou o retorno de elementos religiosos no curso do tratamento, contanto que fosse alcançada a tão desejada eficácia terapêutica

Mesmo com esses problemas, a teoria integrativa encontra certo sucesso atualmente. A ideia de que o acúmulo de técnicas poderia propiciar ganhos de eficácia, bastando para isso o uso com bom-senso dessas técnicas, permite a fácil adesão dos profissionais a essa abordagem. Além disso, no campo político, a abordagem integrativa tem a vantagem de oferecer um ecletismo que confere ao campo das psicoterapias certa 
unidade, uma teoria una, da qual todos podem fazer parte, não excluindo nenhum profissional (nem mesmo psicanalistas) ao mesmo tempo em que submete todos a um grupo único permitindo também se posicionar de modo unificado diante das demandas de regulamentação. Outro argumento favorável é a ideia de que a equivalência entre as diversas técnicas teria como base certo número de fatores comuns e que o uso da psicoterapia integrativa permitiria descobrir quais são, como proposto nas pesquisas conduzidas pelo Boston Change Processes Study Group (2010).

Contudo, movidos por anseios de busca pela máxima eficácia do tratamento, são também deixados de lado os possíveis riscos de efeitos iatrogênicos no curso do tratamento. A combinação de técnicas de origens diversas, a falta de compromisso com as origens teóricas e bases epistemológicas, o uso de técnicas autoritárias na condução do tratamento e a possibilidade de intervenção de aspectos pessoais do terapeuta no tratamento criam uma combinação de fatores que podem ter resultados devastadores para o tratamento e, consequentemente, para o paciente. Acontecimentos das últimas décadas, especialmente no contexto norte-americano, demonstraram os riscos envolvidos no uso de tais técnicas.

\section{O Poder como Causador de Efeitos IAtrogênicos nas PSICOTERAPIAS AUTORITÁRIAS}

Maleval (2004, pg. 44) discute o que classifica como as três grandes epidemias de patologias iatrogênicas já registradas, que se espalharam pela América do Norte nas últimas décadas, quando dezenas de milhares de pacientes norte-americanos foram vítimas de: distúrbios de personalidades múltiplas; síndromes falsas lembranças; ou então relatos sequestros extraterrestres.

Na década de 80, a síndrome de personalidade múltipla assumiu caráter epidêmico nos Estados Unidos, com mais de 30 mil casos registrados em apenas uma década. A partir da apropriação de conceitos psicanalíticos como os de "recalque" e "desmentido" e utilizados fora de seu contexto teórico, psicoterapeutas conduziam 
tratamentos em que buscavam se comunicar com personalidades ocultas de seus pacientes e reencontrar lembranças que, em tese, haviam sido recalcadas pelo paciente. Apoiado no uso desses conceitos, recolhiam relatos e lembranças extravagantes de seus pacientes e conferiam crédito a tais narrativas. No mais das vezes, tais lembranças remetiam à graves episódios de sedução, abuso sexual, tortura, participação em rituais satânicos ou sexuais, realizados por pais ou familiares. Como resultado dessas "lembranças" restauradas, os pacientes, amparados por seus terapeutas, denunciavam às autoridades os abusos supostamente vividos e buscavam a justiça em busca de reparação, sendo pais e familiares investigados e processados por denúncias de satanismo, incesto e abuso de menores. Segundo Mulhern (1994, pg. 237):

"Cerca de $25 \%$ dos "múltiplos" em curso de tratamento não apenas se lembram de sevícias sexuais e outros maus-tratos como enfatizam que seus torturadores eram membros de seitas satânicas, que os haviam forçado a participar de orgias satânicas superelaboradas, de assassinatos e práticas canibais".

Contudo, nunca nenhuma investigação criminal foi capaz de confirmar tais alegações. Como afirma Mulhern (1994, pg. 237):

"aproveitam-se das revisões introduzidas na legislação americana em matéria de lembranças revividas mediante terapia, para impetrar acusações de sevícias em crianças contra pais idosos, de que se lembram agora como adoradores de Satã, incestuosos, assassinos e canibais. Na ausência de provas materiais, a autenticação dos fantásticos relatos de sabás noturnos realizados por essas querelantes recai essencialmente sobre seus terapeutas. Infalivelmente, estes últimos sustentam suas revelações e descrevem esses pacientes como sobreviventes de horríveis provocações, que lutaram corajosamente para que a verdade embutida no âmago de seu inconsciente viesse à tona. Apesar do lado rocambolesco de suas declarações, para os magistrados e os jurados que aceitaram o fato de a acusação de sevícias em crianças constituir efetivamente a prova suplementar da culpa dos acusados, estas são testemunhas bastante persuasivas." 
Ainda que não tenha havido condenações judiciais, as repercussões de casos como esse na mídia e o impacto na vida dessas famílias foram devastadoras. Até hoje pesquisadoras como Judith Herman, professora da Harvard Medical School, seguem como fervorosas divulgadoras de relatos e lembranças de abusos sexuais, recuperadas por meio de tratamentos hipnóticos orientados. Cornelia Wilbur, professora de psiquiatria na Universidade de Kentucky, é uma das principais responsáveis pela multiplicação de perturbações de personalidade múltipla, a partir de sua atuação e divulgação do caso Sybil, no qual a paciente chega a desenvolver 16 personalidades distintas, no curso do tratamento (Schreiber, 1973).

Situação semelhante se desenrolou em relação à síndrome de rapto extraterrestre. O trabalho de John E. Mack (1994), psiquiatra, psicoterapeuta e professor de Harvard, em seu livro Abduction, traz 13 depoimentos obtidos de pacientes via hipnose, centrada em experiências angustiantes vividas pelos pacientes quando abduzidos por alienígenas, sendo vítimas de toda sorte de experimentos e torturas. Mack confirma os relatos de abdução obtidos junto a seus pacientes e os usa como argumento para legitimar seu método hipnótico, conferindo apoio a tais construções de seus pacientes e não considera a síndrome de rapto extraterrestre como uma criação iatrogênica de seu tratamento hipnoterapêutico e defende ativamente a inserção da subjetividade do terapeuta no tratamento.

Nestes casos epidêmicos, temos mostras dos riscos envolvidos no uso de técnicas autoritárias de tratamento (baseadas principalmente na hipnose), no uso indevido da subjetividade do terapeuta no curso do tratamento e na apropriação, deslocamento e aplicação inadequada de conceitos da teoria psicanalítica. Uma aproximação nociva entre psicanálise e psicoterapia, eu que se perde a especificidade da prática psicanalítica ao dissociar conceitos como o de recalque e desmentido de outros elementos da teoria psicanalítica como complexo de castração ou pulsão de morte, por exemplo. Os psicoterapeutas envolvidos utilizavam os conceitos de recalque e desmentido para justificar lacunas na memória de seus pacientes e, posteriormente, preencher tais lacunas com uma etiologia fantasiosa de suas perturbações, com lembranças de abusos e torturas vividos no passado. O resultado foi a emergência de 
efeitos iatrogênicos gravíssimos para os pacientes, resultantes dessa tentativa de diluir a psicanálise numa teoria da influência e incorporá-la às psicoterapias.

Já no final da década 90, trabalhos como o de Ganaway (1989), Loftus \& Ketcham (1994) e Spanaos (1996), alcançam certo reconhecimento ao denunciar os riscos e efeitos iatrogênicos causados pelo uso dessas técnicas psicoterapêuticas. Em 1997, pautados por tais pesquisas, o Royal College of Psychiatrists toma a decisão de orientar seus psiquiatras para que não tentem mais incitar seus pacientes a rememorar abusos sexuais da infância de seus pacientes. Contudo, ainda que tais tratamentos tenham sido conduzidos por psicoterapeutas, tais críticas aos casos de iatrogenia que ocasionaram estas epidemias acabaram sendo direcionadas também à psicanálise e à teoria freudiana, ante a falta de clareza da distinção entre os dois campos.

Os psicanalistas não apenas não participaram das causas dessas iatrogenias mas, inclusive, estiveram entre os primeiros a denunciar os riscos iatrogênicos envolvidos nestas práticas psicoterapêuticas, bem como a responsabilidade dos psicoterapeutas pela gênese dessas epidemias. Mesmo assim foram colocados como culpados pela sua ocorrência, seja por parte dos autores de trabalhos científicos sobre o tema (como os mencionados acima), seja por parte da mídia e da sociedade que equiparavam psicoterapeutas e psicanalistas como um grupo só, sendo ignorado o fato de que os psicoterapeutas fizeram uso indevido de conceitos psicanalíticos, assumindo uma postura de maestria ante seus pacientes. Psicanalistas norte-americanos se ressentem até hoje dos impactos que as iatrogenias causadas por psicoterapeutas tiveram sobre o campo psicanalítico.

Vimos então como, nas últimas décadas, houve uma crescente aproximação entre psicanálise e psicoterapia, que cada vez mais se confundem, combinando e integrando elementos de cada uma das práticas e avançando rumo a uma unificação do campo das psicoterapias, capaz de englobar e fazerem equivalente as diversas técnicas existentes, a partir de uma ótica que busca enquadrar as diversas práticas clínicas a partir de um conceito unificador, como, por exemplo, o uso da influência visando à eficácia terapêutica, como proposto por Nathan. Em contrapartida, se perde nesse processo a possibilidade de discussão acerca daquilo que seria a especificidade da 
psicanálise, em relação a seus efeitos pretendidos, aos usos que faz do poder no curso do tratamento e a preocupação acerca dos riscos causados pelo uso indevido da sugestão na condução do tratamento, que poderia produzir efeitos iatrogênicos gravíssimos, como no caso das epidemias iatrogênicas discutidas acima.

Diante de um cenário como esse, seria possível ainda, hoje em dia, sustentar uma especificidade da psicanálise frente ao campo das psicoterapias ou mesmo às chamadas terapias relacionais? Pode-se praticar psicanálise sem intervenção da sugestão insidiosa inaugurada pelo apoio na contratransferência? Partindo da especificidade da psicanálise, de que modo é possível compreender as relações de poder envolvidas no tratamento e os possíveis efeitos iatrogênicos que dela podem emergir?

\section{Os Usos da Sugestão na Psicanálise}

Como visto no tópico anterior, Maleval denuncia a emergência de certo ecletismo contemporâneo no campo das psicoterapias, com uso combinados de técnicas diversas (a chamada abordagem integrativa) para abordar os problemas clínicos trazidos pelo paciente. $\mathrm{O}$ argumento dessa abordagem é de que todas as modalidades de tratamentos ou técnicas psicoterapêuticas seriam apenas variações da aplicação de um mesmo princípio: a influência sobre o paciente. Assim, a partir de uma teoria da influência, autores como Nathan, sustentam que é possível enquadrar todas as psicoterapias como modos variados de uso da influência para modificar ou tratar um paciente.

Nisso são descartadas considerações acerca das bases epistemológicas e pressupostos de cada abordagem teórica, e chega-se a sustentar que o bom terapeuta seria aquele que domina o maior número de técnicas, sendo capaz de alternar entre uma e outra ou até mesmo combiná-las, na busca pelo melhor tratamento para o paciente.

Contudo, ao se sustentar uma desvinculação entre avanço epistemológico e avanço terapêutico, e propor esse método integrativo, focando exclusivamente na aplicação de um método e na eficácia terapêutica, perde-se a possibilidade de uma 
discussão sobre a ética envolvida no tratamento. Tal abordagem de ecletismo terapêutico faz perder de vista a íntima relação entre técnica e ética, de modo que uma mudança na técnica pode ser acompanhada de uma mudança na ética, ou seja, nos fins perseguidos. E o inverso também é válido. O exemplo do percurso de Freud é claro nesse sentido.

Num primeiro momento para Freud (1885 a 1895), a partir de sua formação na escola de Berheim, o poder de cura estava essencialmente calcado no que era chamado de poder da sugestão, via hipnose. A princípio Freud via na hipnose a possibilidade do exercício de um poder quase ilimitado sobre o outro:

"por meio da sugestão sob hipnose, é possível produzir, influenciar, impedir (inibir, modificar, paralisar, ou estimular) todos os fenômenos subjetivos conhecidos da mente humana e uma grande parte das funções objetivamente conhecidas do sistema nervoso isto é, influencias às funções sensitivas e motoras do corpo, determinados reflexos e processos vasomotores (a ponto mesmo de causar bolhas!) e, na esfera psíquica, influenciar sentimentos, instintos, memórias, atividade volitiva e assim por diante." (Freud, 1889/1996, p. 136)

A emanação de tal poder advinha da relação de servidão do hipnotizado para com o hipnotizador, este último tendo como meio a sugestão pelo poder da palavra e da personalidade do médico. Além do objetivo terapêutico declarado, para Freud era importante não apenas operar, mas compreender os princípios do seu poder. Nesse sentido não lhe bastava ser terapeuta, mas também clínico - lembrando a lição de Charcot em olhar muitas vezes para os dados até que eles falem. Esse primeiro momento seria então pautado pelo apagamento dos sintomas por meio da autoridade do terapeuta.

Em um segundo momento, o poder da sugestão passa a quer questionado, na medida em que Freud adquiria experiência, de modo que a questão ética envolvida no tratamento foi posta antes mesmo de sua Interpretação dos Sonhos (Freud, 1911/1996). 
Essa virada marca um momento importante e vai aparecer ainda trinta anos mais tarde em Psicologia das Massas e Análise do Eu (1921/1996, pg. 114):

"a sugestão é na realidade um fenômeno irredutível e primitivo, um fato fundamental na vida mental do homem. Essa também era a opinião de Bernheim, de cuja espantosa arte fui testemunha em 1889. Posso, porém, lembrar-me de que mesmo então sentia uma hostilidade surda contra essa tirania da sugestão. Quando um paciente não se mostrava dócil enfrentava o grito: "mas o que está fazendo? Vous vous contre-suggestionez!" eu dizia a mim mesmo que isso era uma injustiça evidente e um ato de violência, porque o homem certamente tinha direito a contra-sugestões, se estavam tentando dominá-lo com sugestões. Mais tarde, minha resistência tomou o sentido de protestar contra a opinião de que a própria sugestão, que explicava tudo, era isenta de explicação."

Há uma mudança importante quando a resistência do paciente à sugestão pode ser compreendida como uma tentativa de manutenção de sua liberdade (Checchia, 2012). Até mesmo porque nem todos os pacientes eram hipnotizáveis, além do fato de que o desaparecimento temporário do sintoma era frequentemente seguido do aparecimento de outros. Mas o ponto fundamental refere-se não apenas à ineficácia da cura ou da eliminação do sintoma, mas uma mudança no registro do entendimento do direcionamento do tratamento e de sua ética. Isso porque aparece como valor norteador da clínica além da cura, a liberdade do sujeito.

Freud embarca então no avanço do método catártico cuja teoria estava baseada na cura que a rememoração de um evento traumático podia provocar, a partir da tentativa de recuperar aspectos da história psíquica da doença. O poder de cura é deslocado da figura do médico para a ab-reação.

O passo seguinte foi o abandono da hipnose, convidando o paciente a falar livremente tanto quanto possa, deixando de lado a autocensura, dando assim o passo para o uso da associação livre enquanto método central da psicanálise, com a saída do terapeuta do lugar de mestria que ocupava com a hipnose, retirando também o sujeito de sua posição passiva. Nesse sentido, os estudos que puderam se encaminhar nessa 
direção deixaram de lado a personalidade do terapeuta enquanto fator de cura. A saída do mestre de cena, é acompanha de uma saída do terapeuta enquanto modelo de identificação, sendo dada ênfase a uma maior neutralidade do terapeuta na condução do tratamento. A incorporação de técnicas é perniciosa se não é acompanhada de uma crítica acerca dos impactos sobre a ética e os pressupostos envolvidos em cada prática.

Como terceiro momento, Freud, ao criar a regra da associação livre, se deparou com novos problemas clínicos. Se antes a força de oposição era entre a força sugestiva do hipnotizador e a liberdade do paciente, agora trata-se de colocar em jogo o embate de forças psíquicas. Nesse momento, a resistência é o grande inimigo a se combater, uma vez que é na resistência ao saber inconsciente que o sujeito se aferra ao sintoma e pode acabar indo no sentido do seu recrudescimento.

O aparecimento da transferência e das interpretações são indícios dos novos remanejamentos das relações de poder no dispositivo da cura (Checchia, 2012). A interpretação surge como efeito do trabalho do analista sobre a associação livre a fim de superar as resistências, o que seria possível apenas no estabelecimento da transferência.

É no caso Dora que Freud (1905/1996) faz sentir pela primeira vez de forma mais clara o peso da transferência. $\mathrm{O}$ analista, ao reconfigurar as relações de poder, se abstém da sugestão e passa a operar pela interpretação a partir da escuta da associação livre, a fim de que o sujeito possa ter acesso à experiência do inconsciente. E o que o analisante não lembra que ocorre, ele repete na presença do analista:

"O que são as transferências? São reedições, reproduções das moções e fantasias que, durante o avanço da análise, soem despertar-se e tornar-se conscientes, mas com a característica (própria do gênero) de substituir uma pessoa anterior pela pessoa do médico. Dito de outra maneira: toda uma série de experiência psíquicas prévia é revivida, não como algo passado, mas como um vínculo atual com a pessoa do médico" (Freud, 1905/1996, p. 111)

Nesse sentido, vamos acompanhando que a mudança de uma teoria, de problemas clínicos, é acompanhada da mudança de sua ética, dos seus fins perseguidos e, consequentemente da posição em que o analista se coloca diante do paciente. O que 
começa com a simples eliminação sintomática passa, a grosso modo, pela rememoração de um evento esquecido e produtor de efeitos, seguido de sua interpretação até a sua atualização na transferência, terreno onde se torna possível abordar o sintoma como expressão de um conflito.

Mas o que garantiria que a transferência ou a interpretação também não poderiam ser equipadas à poderosa influência advogada por Nathan. Sem dúvida, há elementos da sugestão envolvidos no processo analítico. Se, como vimos, a sugestão é fenômeno originário irredutível da vida psíquica, seria difícil sustentar que o método psicanalítico seria capaz de excluir completamente a sugestão. Mesmo em Freud, já encontramos pistas da dificuldade em se eliminar totalmente a sugestão da prática psicanalítica, quando afirma: "É muito provável, também, que a aplicação em larga escala da nossa terapia nos force a fundir o ouro puro da análise livre com o cobre da sugestão direta." (Freud, 1918/1996, pg. 181).

Ainda que haja uma recusa, por parte do psicanalista, em utilizar os poderes da sugestão com objetivo de moldar seu paciente, não se pode conceber que ela não intervenha no tratamento. Contudo, ao retomar a definição de Freud acerca da sugestão, podemos conceber melhor a distinção entre a influência como proposta por Nathan e a sugestão que opera na psicanálise. Para Freud (1912a/1996), temos que a sugestão é: "Influência exercida sobre um sujeito por meio dos fenômenos da transferência que ela é capaz de produzir.”.

A abordagem de Nathan se equivoca pois, dessa definição colocada por Freud, utiliza apenas a primeira palavra: influência. Ignora e descarta os aspectos do sujeito e a relação transferencial que emerge no encontro com o terapeuta. Assim, ao excluir a subjetividade do paciente e a relação transferencial, resulta a influência como forma violenta de sugestão aplicada por um terapeuta-mestre sobre um o paciente não dotado de fantasias, mas sim um doente plástico. Ao tentar enquadrar a psicanálise no campo das psicoterapias de influência, perdem os fatores complexos que intervém no processo de mudança e com isso perde-se a própria psicanálise. 
Há ainda outra diferença no uso feito da sugestão pela psicanálise, que reside no fato de que, no curso do tratamento psicanalítico, a sugestão mesma apareceria em forma de transferência, podendo ela mesma ser analisada:

\begin{abstract}
"em qualquer outro tipo de tratamento sugestivo, a transferência é cuidadosamente preservada e mantida intocada; na análise, a própria transferência é sujeita a tratamento, e é dissecada em todas as formas sob as quais aparece. Ao final de um tratamento analítico, a transferência deve estar, ela mesma, totalmente resolvida; e se o sucesso então é obtido ou continua, ele não repousa na sugestão, mas sim no fato de, mediante a sugestão, haver-se conseguido superar as resistências internas e de haver-se efetuado uma modificação interna no paciente" (Freud, 1917/1996, pg. 453).
\end{abstract}

A sugestão, quando permanece intocada, encobre e deixa inalterados os processos que levaram à formação do sintoma, bem como as relações de poder estabelecidas entre terapeuta e paciente, reforçando o caráter de mestria envolvido nesta relação hierárquica. É essa a conclusão a que chega também Maleval (2004) ao ressaltar a importância de diferenciar a psicanálise do grupo de técnicas psicoterapêuticas pautadas na influência sugeridas por Nathan. Colocar a psicanálise no mesmo grupo das psicoterapias de sugestão seria perder a própria especificidade da prática psicanalítica.

Enquanto as psicoterapias se servem da posição de mestres, para exercer seu poder de influência e moldar o paciente, tal qual um objeto, plástico, que deve ser direcionado para um objetivo de cura pré-estabelecido pelo terapeuta, o analista, por outro lado, recusa a posição de mestre. Recusa-se a influenciar o analisante, buscando ocupar uma posição ética específica, de semblante ao objeto, que promove os furos e falhas no saber, de tal modo que a própria questão da identificação do analisante ao analista e das relações de influência possam emergir na transferência, sendo também objeto de análise, indo no sentido contrário a uma identificação do analisante à pessoa do analista. Segundo Safouan (1985, pg. 41): 
"Face a esta Coisa freudiana, a responsabilidade do analista não poderia estar situada em outro ponto, segundo Lacan, senão em seu saber ignorar, ignorar o que ele sabe ou pôde saber"

A premissa, de fato, é a de que o sujeito que esteja ocupando a função de analista, tenha feito seu percurso de análise, se não concluído, já adiantando o suficiente a fim de que esteja mais prevenido acerca dos efeitos aos quais ele também é sujeito. Ou seja, que ele testemunhe um pouco daquilo que ultrapassa a forma de seu eu coeso, de senhor de sua conduta. Acontece que passar por um processo de análise equivale a dizer de alguma forma que o sujeito se reconhece em alguma medida como sendo efeito do inconsciente, responsabilizando-se sobre ele. Ciente de que é, antes de tudo, falado pelo Outro, e que é a partir daí que o sujeito pode advir. E quem diz processo, diz em tempo para a constituição de um sujeito, e é nesse sentido que a cada psicanalista que está em formação é a própria psicanálise que se reinventa.

A psicanálise é dependente de um processo histórico. Foi preciso que várias ideias fracassassem diversas vezes para que ela pudesse avançar. Como indica Safouan (1985), o próprio fracasso da Escola Freudiana de Paris (EFP), como proposta por Lacan, permitiu extrair avanços importantes sobre os efeitos nocivos das relações de poder e identificação para a psicanálise. A psicanálise como herdeira em larga medida das pretensões iluministas, adquire esse desejo de liberdade, mas uma liberdade que não implica numa imagem de homem acabado, idêntico a si mesmo, mas justamente seu contrário. Uma das feridas narcísicas é a de que o homem não é senhor em sua própria casa. E ao que a experiência freudiana nos traz de novidade?

A psicanálise como prática que emerge de ideias iluministas, partilha de um desejo de liberdade, podendo reconhecer que para além das formas concretas e imaginárias de um poder externo, há algo no interior do sujeito, formado a partir de seus processos de socialização, uma heteronomia fundamental e constitutiva do próprio sujeito, seja em Freud na figura do superego, seja em Lacan pelo significante S1. São dois conceitos que apontam para o campo da alienação, campo esse formado por relações de poder. 
A psicanálise é a interpretação das raízes significantes daquilo que constitui a verdade do destino do homem. Tal fato compromete mais do que nunca aqueles que assumem o lugar de analista, por que os coloca num lugar inédito, o de se prestar a uma operação graças à qual alguém possa recobrar uma margem, mesmo que seja mínima, de liberdade.

A prática psicanalítica parte de um encontro entre um paciente que sofre, e busca um psicanalista a quem confiar seu sofrimento, e um psicanalista que, ao ocupar seu lugar, faz uma oferta de tratamento e escuta ao paciente, promovendo desde o início uma relação entre os dois: a chamada transferência. A transferência advém da confiança depositada pelo paciente no analista e do sofrimento que o leva a falar e é essa relação que confere ao tratamento sua consistência e permite que paciente coloque em jogo os impasses de seu ser.

Segundo Silvestre (1989), prova do reconhecimento cultural da psicanálise está na língua, que se enriqueceu com palavras e significações introduzidas pela psicanálise. Transferência é uma palavra comum. Pelo dicionário é sinônimo de deslocamento: de pessoas, de objetos e depois, a partir da psicologia do século XIX, de sentimentos. Entretanto o uso mais comum é o que resulta da psicanálise, que reflete sua influência. Cada um desses usos, convém ao psicanalista: transferência de pessoa, pelo retorno do paciente às sessões, transferência de objeto, pelos valores pagos e a transferência de sentimentos, quando o tratamento o provoca.

Transferência é primeiro evocada sob os traços de uma estranha paixão. É a verificação de que uma coisa chega a um lugar onde não aparecia antes. Deslocada, toma uma significação e uma função inéditas; significação e função que se impõem ao sujeito, pois descobre que o que encontra assim é o que procurava. Para Silvestre (1989, pg. 93): “A análise, pela via da transferência, permite uma adequação entre a pergunta do sujeito e sua resposta.".

A partir da transferência e de sua combinação com os conceitos de inconsciente e associação livre, possibilita-se ao paciente que fale e que, ao falar sob transferência, possa emergir aquilo no qual o paciente nem sempre se reconhece, seu desejo, que o 
implica em sua história e em seu sofrimento e evidenciando sua posição de sujeito dividido, que guarda em si algo da ordem do inconsciente, um saber que o determina, que rege sua vida, porém lhe escapa, que o sujeito ignora. Porém, se pretende o alívio de seu sofrimento, ao confiá-lo ao analista, será necessário também que o paciente entre em contato com esse saber, se implicando em seus efeitos. Assim, para que a análise possa transcorrer, não basta que o paciente traga um sofrimento, mas também um questionamento, uma pergunta, dirigida inicialmente ao analista, e que diz respeito a esse saber inconsciente.

O começo da transferência, então, passa também pela possibilidade para o sujeito de reconhecimento desse saber que lhe é estranho, algo que não sabe sobre si, e que, portanto, acaba por situar no campo do Outro. Presume que o Outro é quem sabe e é quem pode lhe responder sobre si. Confia ao analista aquilo que diz respeito ao inconsciente e à verdade de seu ser, aquilo que não sabe de si e que supõe ao analista.

Frente a esse equívoco do paciente, que deposita no analista o saber sobre si, o analista não se coloca em posição de maestria, não se coloca como detentor deste saber pois está alertado, por sua própria experiência de análise, que tal saber é somente suposto, um saber suposto ao analista que, na verdade nada pode saber sobre o inconsciente de seu paciente. Contudo, utiliza-se desse suposto saber para o estabelecimento da transferência e para permitir que o paciente fale em livre associação, podendo o analista decifrar as associações do paciente.

Porém, para que possa realizar esse trabalho, é preciso que o analista esteja aberto à escuta do paciente, sem opor obstáculos e sem permitir que seus próprios aspectos subjetivos interfiram no tratamento. Assim, não se trata apenas de recusar a posição de maestria e detentor de um saber, mas também de se negar a permitir que seus próprios aspectos subjetivos ou contratransfereciais possam intervir e atrapalhar o rumo do tratamento. Neste sentido, Silvestre (1989, pg. 96):

"Que ele [analista] entenda o que lhe é dito - mais exatamente, que ele entenda além do que lhe é dito - necessita que ele não oponha nenhuma barreira a seu entendimento. Preconceitos, prevenções, opiniões diversas ou julgamentos apressados, evidentemente, não 
cabem aqui. Devem mesmo ser banidos pelo analista. Igualmente, ele deve manter-se afastado da esfera dos sentimentos e dos estados da alma. (...) Sua função não é de compaixão, nem mesmo de simpatia nem compreensão; sua função consiste em marcar o que a transferência produz fora do inconsciente para aí revelar o desejo assim veiculado pela palavra. (...) $\mathrm{O}$ analista, como Lacan sublinha, não tem como guia a sua subjetividade, basta a do paciente. Digamos, sem repisar, que o analista estaria mais do lado da objetividade."

Para que seja capaz de sustentar essa posição, é necessário que o analista tenha ele mesmo passado pela experiência do inconsciente, em sua análise pessoal, mas não apenas isso. É necessário também que possa sustentar seu conhecimento teórico, sua prática clínica e sua posição de analista, fazendo uso adequado dos conceitos psicanalíticos adquiridos ao longo de sua formação, sua técnica, evitando quaisquer entraves ao funcionamento do dispositivo analítico ou, em outras palavras, a resistência, que, para Lacan, é sempre da parte do analista, quando permite que seus aspectos subjetivos e contratransferenciais se coloquem como obstáculo ao tratamento.

Sobre esse ponto, Silvestre (1989, pg. 99) afirma ainda:

"É fácil pois simplificar as habituais elucubrações de certos analistas sobre o que denominam 'contratransferência'. Não há nenhuma simetria ou reciprocidade na análise, como também o analisando não está submisso, dependente da pessoa de seu analista. $\mathrm{O}$ analisando depende tão-somente de sua demanda de análise e do prêmio que ele visa, aí colocado por ele, como também está submetido só ao desejo que aí o conduziu."

O analista também está submetido ao dispositivo clínico e seus preceitos, devendo se manter fiel e comprometido ao seu lugar de analista, excluindo sua subjetividade. Assim, não se trata exatamente de uma neutralidade passiva do analista, mas sim da possibilidade de sustentar ativamente sua escuta clínica e sua posição de analista, visando sempre à direção do tratamento. Neste sentido, Soler (1989, pg. 105): 
"De quantos sugerem, político, educador, até médico, a quem interpreta, o analista, vai a distância do dizer o que deve ser ao dizer o que é. Eles se distinguem como a prescrição que comanda se opõe à decifração do real. No princípio disso encontra-se a rejeição das técnicas da hipnose e da sugestão. De Charcot e de Bernheim a Freud, a distância se avalia pelos recursos dos quais este se priva. Questão de ética, pois há necessidade de um desejo, o de ser o mestre sendo contraditório ao do analista, e Jacques Lacan ministrou, durante um ano inteiro, um seminário sobre a Ética da Psicanálise. Ela implica em deixar em suspenso os objetivos do domínio, ainda que imbuídos das melhores intenções, em favor de uma busca epistêmica do ser, que faz da psicanálise 'uma terapêutica como não há outra'."

Mas se temos então na psicanálise uma especificidade, um dispositivo clínico que difere das psicoterapias e que propõe uma postura ética diversa, uma recusa da posição de maestria, um uso e direcionamento distinto dos poderes de sugestão e uma interdição à intervenção de aspectos subjetivos no rumo do tratamento, o que isso representa para a distinção entre psicoterapia e psicanálise e para os possíveis riscos e efeitos iatrogênicos do tratamento?

Ao delinear tais especificidades do tratamento psicanalítico, nos deparamos com a possibilidade de uma divisão dentro do campo psi e de distinção mais rigorosa entre psicoterapia e psicanálise, a partir da aceitação ou recusa da posição de maestria. Para Miller (1992, pg. 9): “O fator-chave de toda psicoterapia, é que há um Outro que diz o que é preciso fazer, um Outro a quem obedece o sujeito que sofre e do qual ele espera aprovação”, o que seria o ponto distintivo entre psicoterapia e psicanálise. Neste sentido, Maleval (2005, pg. 94):

"A maior clivagem do campo psi não é inerente a categorias profissionais: ela separa os adeptos das psicoterapias autoritárias, fundadas na imposição pelo mestre-terapeuta numa técnica normatizada, e aqueles que se apóiam na demanda para obterem uma mutação subjetiva, os psicanalistas..." 
Assim, temos de um lado as psicoterapias autoritárias, que centralizam o saber na pessoa do terapeuta, responsável por intervir sobre o paciente, impondo um caminho de cura pré-estabelecido, e, de outro lado, os psicanalistas e psicoterapeutas relacionais que colocam o saber do lado do paciente, conferindo-lhe a autonomia para ditar os rumos de seu próprio tratamento.

Mas haveria ainda certa confusão a ser resolvida entre as psicoterapias psicanalíticas que se expandem no âmbito da IPA e a psicanálise como proposta pelas escolas lacanianas. Para isso será necessária uma breve discussão acerca dos objetivos e efeitos previstos para o tratamento.

Como já mencionado, nas psicoterapias o objetivo do tratamento está mais relacionado a um fortalecimento do $\mathrm{Eu}$ e a identificação do paciente ao ego forte do terapeuta, sendo o processo de mudança terapêutica relacionado a uma crescente adesão às concepções e ao sistema teórico proposto pelo terapeuta, sendo maior o sucesso do tratamento quanto maior for o acordo a que chegam as partes ao seu final, ou seja, uma aposta nos processos de identificação entre analista e paciente. Sobre isso, Miller (1992, pg. 9), afirma:

"todas as terapias são de fato terapias da imagem de si, e são sempre fundadas no estádio do espelho. Trata-se de restaurar no eu suas funções de síntese e de mestria, sob o olhar do mestre que desempenha o papel de modelo. São terapias pela imagem que, por isso mesmo, são terapias pelo mestre, pela identificação com o mestre"

De tal modo, é comum que a percepção dos efeitos terapêuticos pelo paciente esteja relacionada à aquisição de certas explicações ou conhecimentos sobre si e sobre seu funcionamento, seus mecanismos psicológicos que, uma vez revelados, poderiam ser agora controlados e dominados, tendo chegado ao fundo de suas questões e alcançado o pleno controle sobre si. A noção de um homem acabado, livre, senhor de si, um ideal de liberdade. 
Por meio das psicoterapias, o sujeito encontra conforto em suas fantasias imaginárias de autonomia e autossuficiência, unidade e coincidência consigo mesmos. Para Maleval (2004, pg. 54):

"Experiência falaciosa da liberdade sem limites, que sempre acaba sendo acompanhada pela obrigação de aumentar ao máximo o número de escolhas, de um sentimento de ter sido mal amado pelos pais e seguir incompreendido pelos outros, sendo os outros aqueles que têm que levar a responsabilidade pelos distúrbios do sujeito. (...) A opacidade do fantasma fundamental permanece incólume e a exaltação da autonomia egóica leva infalivelmente o sujeito à amarga constatação da solidão."

A psicoterapia, então, se adequa e se articula à fantasia de cada paciente, afastam o sujeito de seu fantasma e o impedem de se deparar com sua falta, a partir da identificação ao ego forte do analista. O objetivo do tratamento então, seria o de aumentar as opções do paciente na condução da vida (Szasz, 1965), aumentar as escolhas possíveis (Von Forester, 1991), numa postura bem coadunada com o ideal norte-americano vigente na época, de um homem livre, self-made man, capaz de alcançar seu máximo potencial, escapando das barreiras impostas pela castração e pelo inconsciente. Tais objetivos ainda se fazem presentes em psicoterapias psicanalíticas, especialmente no âmbito da IPA.

Por outro lado, o tratamento psicanalítico, como proposto principalmente pelas escolas lacanianas, é aquele em que o analista ocupa uma posição ética, posição de objeto a, não assumindo a posição de mestre e nada querendo para o paciente. Segundo Zenoni (1991, pg. 132):

"O analista não se identifica com o Outro, nem com o Outro que sabe, nem como o Outro que faz dom de sua ignorância ('Sou apenas um homem como você'), mas confere semblante ao objeto que esburaca os ditos, as lembranças, as associações do analisante, o objeto que permanece ininterpretável na própria interpretação: não o elemento último do saber, mas o que causa uma falha no saber. Com isso, os ditos do analista não são articulados ao saber, 
mas àquilo que permanece inassimilável ao saber, a uma presença que repugna inclusive ao saber, pois é a de um objeto que, por causar o desejo, por isso não deixa de ser menos desejável... O enigma não está mais do lado do neurótico, mas do lado do analista. Ao mesmo tempo, não é mais o analisante que vai sobrecarregar o analista, que fazê-lo trabalhar, mas o contrário: é o analista que dá forma à causa enigmática da demanda silenciosa do sujeito. Com essa troca dos termos da relação, opera-se a passagem do campo psicoterapêutico para o campo propriamente analítico da prática simbólica."

Assim, a posição ética, específica da prática psicanalítica, se desdobra também para os fins buscados pelo tratamento. Em oposição à busca por um fortalecimento do Eu e identificação à pessoa do analista, presente nas psicoterapias psicanalíticas, a psicanálise promove no sujeito a implicação em sua história e seu desejo, deparando-se com sua falta constitutiva e aproximando-se do contato e travessia de seu fantasma.

Tais aspectos permitem localizar de melhor modo o que configuraria o específico da prática psicanalítica, distinguindo-o de outras práticas do campo psi, em especial, as psicoterapias. Além disso, tais distinções tem implicações para além da clínica, alcançando o campo social e político, em especial na relação com os campos da ciência e da política: exigências de provas acerca da eficácia do tratamento e dos resultados alcançados, demandas de regulamentação do campo; criação de protocolos e regras fixas para condução dos atendimentos. Diante de tais exigências, alinhadas com um discurso de maestria, uma nova cisão: de um lado aqueles que se alinham e respondem a estas demandas, grupos compostos principalmente pelos psicoterapeutas de abordagens mais autoritárias, de outro lado aqueles que rejeitam intervenções externas, grupo composto, principalmente, pelos psicanalistas e psicoterapeutas relacionais.

A IPA, ao propor a aproximação entre psicoterapia e psicanálise, deixando de lado aspectos éticos típicos da prática psicanalítica, faz um movimento para se aproximar e se inscrever nos discursos científicos e jurídicos. Vinculados a tais objetivos científicos, são conduzidas pesquisas clínicas e experimentais visando dar 
provas de eficácia dos tratamentos. Porém, uma vez que tais grupos envolvidos nestas pesquisas e também aliados ao discurso científico são também aqueles que se afastam das questões éticas sustentadas pela psicanálise, o resultado é que tais pesquisas deixam de questionar de modo mais profundo o que, exatamente, configuraria o sucesso ou fracasso de um tratamento, reduzindo o escopo das pesquisas a critérios objetivos como o grau de êxito na diminuição de um sintoma apresentado pelo paciente.

Do mesmo modo que tais pesquisas traçam critérios de eficácia incompatíveis com os pressupostos da psicanálise, também quanto à iatrogenia, as pesquisas conduzidas são de pouca utilidade, se tomarmos como base o enfoque psicanalítico. Assim, ainda que existam na literatura pesquisas sobre o tema da iatrogenia no campo das psicoterapias, conforme os resultados apresentados no capítulo anterior, deve-se ter cautela ao considerar tais resultados, não sendo possível transpor tais critérios e aplicálos de modo imediato ao tratamento psicanalítico, vez que os próprios pressupostos que orientam tais pesquisas, no mais das vezes, se mostram incompatíveis com os preceitos psicanalíticos quanto ao uso do poder na direção do tratamento, bem como os objetivos pretendidos com o tratamento.

\section{A Questão do Poder na Psicanálise}

Partimos nesse capítulo da proposta de que para poder avançar na pesquisa acerca dos riscos e potenciais iatrogênicos do tratamento psicanalítico, seria necessário, primeiramente, delimitar o que seria o específico da prática psicanalítica, para depois localizar critérios para identificar os possíveis riscos iatrogênicos que se fazem presentes.

Neste sentido, a proposta feita por Maleval, e apresentada acima, nos fornece um primeiro ponto de apoio. Ao propor essa divisão entre psicanálise e psicoterapia, situando os efeitos iatrogênicos (como no caso das três epidemias iatrogênicas norteamericanas) como efeito da atuação psicoterapêutica pautada na posição de maestria e de exercício de poder, Maleval localiza também o que seria o específico da psicanálise, 
ao recusar essa posição de dominação sobre o paciente. A partir disso, argumenta que tais riscos iatrogênicos típicos de uma prática psicoterapêutica não se fariam presentes na psicanálise.

Tal exposição parece apresentar a tese subjacente de que a psicanálise, ao sustentar a especificidade de sua prática, com a recusa do psicanalista à posição de mestre, teria sido capaz de fornecer uma solução capaz de eliminar - ou ao menos reduzir substancialmente - os efeitos iatrogênicos do tratamento que ocorrem nas psicoterapias. Contudo, é preciso questionar se essa hipótese de fato se sustenta.

Podemos concordar com Maleval e outros autores na leitura que fazem acerca da etiologia das epidemias iatrogênicas, como resultado de erros na condução do tratamento psicoterapêutico, em especial no tocante ao uso feito do poder no curso do tratamento. E se reconhecemos que tais iatrogenias foram resultado de intervenções a partir da posição de mestre e de uso indevido do poder, podemos concordar que a psicanálise ao menos apresenta um dispositivo não apenas atento a esse risco, mas que se configura de modo a buscar evitar esse uso tipo de uso do poder. E essa recusa em fazer esse exercício do poder seria, para Maleval, o que configuraria a própria especificidade da prática psicanalítica, reduzindo também o seu potencial iatrogênico.

Porém, podemos pensar em pelo menos duas críticas a essa proposta de Maleval, e que irão nos permitir também avançar sobre este tema. A primeira crítica é em relação a essa crença, para nós equivocada, de que a psicanálise teria sido capaz de, com seu dispositivo, resolver ou superar o problema do exercício de poder no tratamento. A segunda crítica é em relação a essa concepção que reduz o específico da prática psicanalítica à posição ética adotada pelo psicanalista, enquanto aquele que se recusa ao exercício do poder. Vamos abordar cada um desses pontos separadamente.

Lima (2012), em sua dissertação sobre Foucault e a constituição histórica da questão do poder na clínica psicanalítica: considerações metodológicas, propõe uma abordagem Foucaultiana da questão do poder na psicanálise. O ponto de partida de seu trabalho é justamente enfrentar essa certa crença comum no campo psicanalítico, de que o problema do exercício do poder no curso do tratamento teria sido superado, de modo 
que o poder não seria mais uma questão no interior do dispositivo analítico. Extraindo de Canguilhem a expressão "fatos de saber"7, Lima tece uma crítica a uma concepção que reduz o tema do poder na clínica a uma mera questão acerca de se o poder é ou não é exercido pelo analista em sua prática. Nesse sentido Lima (2012, pg. 20) afirma:

“Ou seja, o 'fato de saber' aqui considerado indesejável é aquele que insiste em advogar de forma pendular em defesa da existência ou da não-existência da relação de poder na transferência, uma vez que, de uma posição, poder-se-ia criar expectativas que só fariam avançar em direção à proliferação de novos 'fatos de saber'. (...) $\mathrm{O}$ intento aqui é se esquivar de tal tentação, pois é preciso assumir como questão, antes, investigar se a clínica psicanalítica se sabe enquanto questão de poder."

Trata-se, então, de desconstruir uma abordagem que toma a questão do poder no campo psicanalítico apenas como disputa sobre o exercício ou não desse poder por parte do analista. Mais do que isso, esse aporte da teoria foucaultiana trazido por Lima nos apresenta a desconstrução de uma concepção de poder na clínica que a reduza apenas à dimensão da possibilidade de um poder exercido pelo analista sobre o paciente. Pelo contrário, o que Lima nos apresenta, a partir da obra foucaultiana, é justamente uma subversão dessa concepção, vez que, para Foucault, o poder se faz sempre presente no discurso e nas relações entre aqueles que tomam parte nesse discurso:

"O poder não está, pois, fora do discurso. O poder não é nem a fonte nem a origem do discurso. O poder é algo que funciona através do discurso, porque o discurso é, ele mesmo, um elemento em um dispositivo estratégico de relações de poder." (Foucault, 1978/1994, p. 465)

A partir dessa concepção, o que temos é que o poder se manifesta, na verdade, não como um exercício de poder, vindo de cima para baixo, de uma parte que exerce o

\footnotetext{
${ }^{7}$ Segundo Canguilhem: "a história das ciências é vítima de uma classificação que ela aceita como fato de saber, tendo em vista que o problema é o de saber de que fato procede essa mesma história" (Canguilhem, 1977, p. 26)
} 
poder, sobre outra que apenas o recebe e é submetida. O poder se aproxima mais de um jogo, de uma dinâmica constante de enfrentamento e resistência, que opera em ambos os sentidos, de uma parte a outra. Neste sentido, com Foucault:

"As relações de poder suscitam necessariamente, apelam, a cada instante, abrem a possibilidade a uma resistência, e é porque há possibilidade de resistência e resistência real que o poder daquele que domina tenta se manter com tanto mais força, tanto mais astúcia, quanto maior for a resistência. De modo que é mais a luta perpétua e multiforme que procuro fazer aparecer do que a dominação morna e estável de um aparelho uniformizante." (Foucault, 1977a/2010, p. 232)

Tal concepção tem o condão de devolver ao indivíduo, antes tomado apenas como oprimido, vitima, receptáculo dessa imposição de poder, o seu estatuto de sujeito e sua responsabilidade, sua possibilidade de participação e resistência na dinâmica desse jogo de poder. Perceba-se aqui que Maleval, ao reduzir a questão do poder na clínica a uma discussão sobre exercício ou não do poder por parte do psicanalista, e ao criticar as psicoterapias por exercerem esse poder e tomarem o paciente como objeto plástico a ser manuseado, na verdade está partilhando dessa concepção equivocada das relações de poder que reduzem o paciente a mero alvo da incidência de um poder exercido pelo analista. Ou seja, acaba por recair em sua própria crítica ao também reduzir as possibilidades de reconhecer o paciente enquanto sujeito ativo nessa disputa de forças que se desenrola no curso de um tratamento.

Desse modo, ao pensarmos o modo como a relação entre poder e a psicanálise se articula à questão da responsabilidade do analista, não se trataria de considerar meramente os mecanismos para impedir o exercício de poder por parte do analista sobre o analisante. Em primeiro lugar, por que não se poderia pensar em um campo discursivo isolado das relações de poder, alheio a esse jogo de poder ou onde a questão do poder estivesse plenamente superada, não sendo possíveis dispositivos capazes de configurar "praias de liberdades elementares" (Foucault, 1977b/2010, p. 248). E, em segundo lugar, por que esse jogo de poder, essa dinâmica de uso do poder e resistência se faz 
presente no discurso como um todo, não apenas no sentido do analista sobre o analisante, mas também inversamente, do analisante para o analista. É neste escopo que retomamos a crítica promovida por Lima quanto a esse "fato de saber" que cristaliza a ideia de que o poder se exerce por parte do analista, sobre o paciente. Lima (2012, pg. 22) afirma:

\begin{abstract}
“Quanto mais os 'fatos de saber' sobre como tal relação se dá se proliferam, mais distantes parecemos estar da conceitografia psicanalítica, da diagnóstica e, de maneira especial, da experiência analítica. Perguntas como esta nos permitem imprimir um tom alusivo ou performático para o que chamamos anteriormente de investigação dos modos pelos quais a psicanálise se reconhece ou não se reconhece enquanto questão de poder."
\end{abstract}

Trata-se, portanto, não apenas de pensar se um tratamento está ou não configurado como exercício de poder por parte do analista, mas sim de pensar as dinâmicas de poder envolvidas no tratamento como um todo, para daí poder articular qual seria a responsabilidade assumida pelo analista na condução do tratamento e quais seriam os possíveis riscos envolvidos nessa prática.

Sobre isso, podemos avançar com Foucault, tomando o modo como se posiciona diante de certa crítica no sentido de que, em sua analítica, o poder está em todo lugar. Foucault não nega esta onipresença do poder, mas insiste para que se possa reconhecer que “que nunca se possa estar 'fora do poder' não quer dizer que se está inteiramente capturado na armadilha" (Foucault, 1977b/2010, p. 248).

Lima nos ensina também que o "estar inteiramente capturado na armadilha" pode ser aproximado de outro conceito da obra Foucaultiana, diverso do conceito de poder, que é o de dominação. Por dominação, devemos entender a situação em que o poder se configura de modo mais acabado e cristalizado, não havendo mais espaço de manobra para que o jogo de poder se desenrole, "já que para Foucault, a dominação é a forma terminal da relação de poder, é a sua forma congelada." (Lima, 2012, pg. 31). Para compreender essa concepção de dominação é necessário ainda o recurso a outro conceito que é o de liberdade. Aqui, liberdade tomada como o que é inerente à 
possibilidade de que haja um jogo de poder, sendo a dominação justamente o caso em que o exercício do poder, em sua forma máxima, é capaz de eliminar a possibilidade de liberdade e resistência do sujeito:

"O poder não se exerce senão sobre 'sujeitos livres' e na medida em que eles são 'livres'. Entendemos por isso sujeitos individuais ou coletivos que têm diante deles um campo de possibilidade onde se podem dar muitas condutas, muitas reações e diferentes modos de comportamento. Ali onde as determinações estão saturadas, não há relações de poder. A escravidão não é uma relação de poder quando o homem está encadeado (então se trata de uma relação física de coerção), mas justamente quando pode deslocar-se e, no limite, se escapar. Não há, pois, um cara a cara do poder e da liberdade, com uma relação de exclusão entre eles (em todo lugar onde se exerce o poder, desaparece a liberdade); mas um jogo muito mais complexo. Neste jogo, a liberdade aparece como a condição de existência do poder" (Foucault, 1977a/2010, p. 237-238)

Neste sentido, Maleval avança ao conseguir identificar o risco de uma situação cristalizada de dominação, que acaba por privar o sujeito de sua liberdade e levando à emergência de efeitos iatrogênicos. Porém, compreende mal o problema ao equiparar dominação e exercício de poder, considerando, então, que a solução seria uma via livre do exercício de poder e que esta teria sido a via alcançada pela psicanálise. O de que se trata, na verdade, é de que a prática psicanalítica não seja reduzida apenas a um exercício de um poder, o que não significa negar ou tomar como resolvida a questão do poder no fluxo do tratamento. Neste sentido podemos retomar a célebre frase de Lacan, em A direção do tratamento e os princípios de seu poder (1958/1998, pg. 592): "Pretendemos demonstrar como a impotência em sustentar autenticamente uma práxis reduz-se, como é comum na história dos homens, ao exercício de um poder". Lacan alerta aqui para o risco de que uma prática não sustentada autenticamente venha a recair exclusivamente (reduzir-se) em um exercício de poder. Mas de modo algum podemos daí extrair que, ao sustentar a prática analítica de maneira autentica estaríamos livres de pensar acerca dos fluxos de poder presentes no tratamento. É a partir disso que podemos compreender o alerta feito por Lacan (1964-1965/2006, pg. 417), quando afirma: 
"Isto não é para nos enganarmos juntos com uma advertência sobre a responsabilidade na prática. Tu sabes bem que todo exercício de um poder não é somente sujeito a um erro, mas a este cúmulo de engano de ser benfeitor em seu erro."

Assim, não apenas temos uma indicação direta de Lacan acerca da prática psicanalítica em sua relação com o poder que teria como consequência, a presença do risco de erros em sua condução, que reduzam a prática a uma dominação ou mero exercício de poder. Mas mais do que isso, Lacan alerta ainda para o risco de que o erro cometido passe despercebido, sendo tomado como uma boa ação por parte do analista, pela ideia de que se está fazendo o bem pelo outro, o que mais uma vez recairia numa situação de restrição da liberdade e autonomia do sujeito, enquanto sujeito ativo dessa relação e desse jogo de poder. Desse modo, a responsabilidade que se trata, do lado do analista, não é aquela de fazer o bem pelo paciente, numa posição de benfeitor, professor, mestre ou outra semelhante, mas tampouco pretender eliminar as relações de poder e resistência em curso no tratamento.

Pelo contrário, a responsabilidade do analista estaria situada justamente na possibilidade de reconhecer essas dinâmicas de poder para, a partir daí, poder operar no sentido de promover incrementos na liberdade do sujeito e, consequentemente, combater situações de dominação, seja no modo como o sujeito se posiciona em sua relação com o outro, seja no âmbito de sua relação consigo mesmo. Como afirma Lima (2012, pg. 36):

"sendo, portanto, a liberdade condição fundamental, ela é: liberdade que se revela contra os instrumentos de repressão e de dominação; liberdade de poder resistir e se (re)posicionar no interior da relação de poder, ou fora dela no ponto em que ela se congela sob a forma da dominação e da repressão; liberdade esta que, por si só, está a favor de uma certa produção, ou seja, liberdade enquanto produção" 
E, no campo da psicanálise, essa via para promover a liberdade do sujeito reside na possibilidade de reconciliar o sujeito com a dimensão de seu desejo. Neste sentido, Lacan (1964-1965/2006, pg. 325):

"Se ser psicanalista é uma posição responsável, a mais responsável de todas, uma vez que ele é aquele a quem está confiada a operação de uma conversão ética radical, aquela que introduz o sujeito na ordem do desejo..."

Retomando então nossa questão do potencial iatrogênico da psicanálise, não cabe que a prática psicanalítica se sustente numa ideia de que seu dispositivo teria resolvido a questão do exercício do poder no tratamento, livre do risco de incorrer em uma dominação e, portanto, livre de riscos iatrogênicos. Pelo contrário, para poder investigar os riscos envolvidos no tratamento trata-se de poder investigar como se dá o funcionamento desse dispositivo, visando identificar quais seriam os aspectos onde esse jogo de poder se faz mais sensível e que, portanto, poderiam representar maiores riscos de efeitos iatrogênicos.

Isso nos leva também à nossa segunda crítica à proposta de Maleval, em relação a essa concepção que reduz o específico da prática psicanalítica à posição ética adotada pelo psicanalista, enquanto aquele que se recusa ao exercício do poder. Se, de fato, temos a dimensão ética do psicanalisa, ao colocar no horizonte do tratamento uma proposta de cura que, como visto, está relacionada à própria liberdade e ao desejo do sujeito, isso não permite inferir que possamos reduzir o todo da prática psicanalítica apenas a essa dimensão ética.

É nesse sentido que trabalha Dunker (2011), com sua proposta de reconstrução da estrutura e constituição da clínica psicanalítica. Ao realizar uma recuperação das diversas práticas de cura, das psicoterapias, dos tratamentos e da clínica, Dunker se propõe a articular as dimensões que possibilitam a constituição da práxis psicanalítica, enquanto uma clínica com características peculiares, distinta, por exemplo, da clínica médica. 
Nessa articulação, sem dúvida, é também dado destaque, tal qual vimos com Maleval, à importância da posição ética da psicanálise enquanto importante fator de diferenciação entre a psicanálise e outras práticas. Neste sentido Dunker (2011, pg. 479):

"Ocorre que, por depender intrinsecamente do sujeito para se efetivar como tal, a psicanálise não pode ser dissociada do desejo do analista e do desejo do analisante. (...) No caso da psicanálise, ela (a ética) é interna ao tratamento. Dentro desta condição, não se pauta integralmente pela eficácia da remoção de sintomas e no abreviamento do sofrimento psíquico, mas encontra-se sempre tensionada com o que examinamos anteriormente por meio da noção de excelência contida na esfera do cuidado de si e do malestar (Unbehagen) que este implica."

Mas, já neste trecho, podemos perceber que, se por um lado a dimensão ética da cura é vital para a práxis psicanalítica, por outro lado temos ainda mais duas dimensões a considerar e incluir no campo da prática psicanalítica, o que no trecho acima é referido como a eficácia da remoção dos sintomas e o abreviamento do sofrimento psíquico. Tal distinção entre essas três vias e a posterior articulação proposta entre elas está ancorada, dentre outros fatores, num caráter de heterogeneidade da práxis psicanalítica, justamente por articular em sua prática três dimensões distintas: a dimensão da clínica, a dimensão da terapêutica e a dimensão da cura. Neste sentido, Dunker (2011, pg. 477):

"Ou seja, um psicanalista não faz sempre a mesma coisa ao longo do tratamento. Ele pode focar-se em momentos mais clínicos, outros mais terapêuticos e outros ainda no qual a cura será o procedimento fundamental. (...) Uma heterogeneidade que é relativa tanto à formação do discurso, quanto à constituição de sua práxis.”

Ou ainda:

"A prática psicanalítica não escapa a esta regra. Tentei mostrar que a heterogeneidade é constitutiva da própria prática psicanalítica 
porque já é uma propriedade que encontramos nas práticas que a constituíram historicamente como tal.” (Dunker, 2011, pg. 614)

Ou seja, se na práxis psicanalítica é inegável a importância desta dimensão da cura, em relação ao mal-estar do sujeito, o que está relacionado a esta posição ética adotada pelo psicanalista e destacada por Maleval, não se deve por isso excluir o fato de que sua prática envolve também o trabalho com pelo menos outras duas dimensões: a dimensão da clínica, com sua diagnóstica e semiologia, permitindo que se possa abordar e tratar dos sintomas apresentados pelo sujeito; e a dimensão da terapêutica, da psicoterapia, que visa dar conta do sofrimento vivido pelo sujeito. É nesse sentido que Dunker (2011, pg. 615) articula:

"Se tratamos sempre do sujeito é possível que, como clínicos, nos dediquemos aos seus sintomas, como psicoterapeutas ao seu sofrimento e como práticos da cura ao seu mal-estar (Unbehagen)"

Mas mais do que considerar a existência dessas três dimensões, clínica, terapêutica e cura, o argumento tecido por Dunker é de que para que possamos caracterizar a práxis psicanalítica é necessária uma concepção capaz de integrar essas três dimensões. Qualquer tipo de solução que envolva excluir alguma dessas dimensões - ou privilegiar apenas uma delas - não mais poderia ser definido como psicanálise. Neste sentido, Dunker (2011, pg. 479) afirma:

"Disso se poderia depreender que se trata, também na psicanálise, de uma técnica - em outras palavras, da prática anônima de um conjunto de regras visando determinado fim ou objetivo. Isso seria desconhecer e repudiar praticamente que a psicanálise é, também, uma forma de cura, além de uma clínica que compreende um tratamento."

E, em resumo:

"Um dos objetivos do texto foi tentar localizar comparativamente o que chamamos de clínica em contraste com o que se chamou 
antigamente de cura e mais recentemente com o que veio a se formar como psicoterapia. Isso permitiu ver que há um uso exagerado do termo "clínica". (...) Esta é uma ideia que eu tentei advogar e defender. Eu preferi pensar a clínica, a terapia e a cura não como matrizes epistêmicas, mas como matrizes éticas. Mas elas não são apenas matrizes éticas. Pelas próprias práticas, contextos e usos onde elas se originaram, elas nos remetem a um campo mais amplo que é a política. Prefiro dizer que são as três políticas formativas da psicanálise e que a definem mutuamente de certa forma. Se você me disser que há uma forma de psicanálise que exclui completamente uma dessas políticas, eu te digo que isto já não é mais psicanálise. A psicanálise depende da articulação entre essas três políticas ou tratamentos, no sentido lacaniano do termo." 8

A partir destas duas críticas apresentadas, extraímos a conclusão de que não se pode pensar numa concepção de psicanálise que vise reduzi-la à sua dimensão ética e muito menos advogar que esta posição clínica seria suficiente para situar a psicanálise fora de um discurso de poder, eliminando assim seu potencial iatrogênico. Como visto ao longo deste capítulo, mesmo o psicanalista não pode se furtar de questionar sobre os princípios que conferem poder a sua prática e, consequentemente, dos riscos envolvidos que o tratamento representa para o paciente. A tese apresentada por Maleval, ao colocar o tema da iatrogenia como essencialmente vinculado à questão ética e ao exercício de poder se mostra limitada. Se de fato o exercício de poder realizado pelas psicoterapias representa aumento no potencial iatrogênico do tratamento, isso não quer dizer que o potencial iatrogênico não se faça sentir também no campo da clínica ou da psicoterapia que, como vimos, também compõem o trabalho do psicanalista. Ou seja, não se pode reduzir a questão dos efeitos iatrogênicos à superfície da ética, crendo que a psicanálise seria plenamente capaz de solucionar essa problemática do poder na clínica, tão pouco aceitando que uma eventual solução neste sentido seria suficiente para eliminar os riscos iatrogênicos do tratamento.

\footnotetext{
${ }^{8}$ Entrevista com Dunker, disponível em http://lacaneando.com.br/christian-dunker/
} 
Assim, mesmo reconhecendo a validade dos pontos apresentados por Maleval, não parece que seja possível limitar todo o campo das possíveis iatrogenias no curso de um tratamento psicoterapêutico ou psicanalítico apenas ao campo da ética. Se o trabalho de Maleval alcança êxito em mapear certo tipo de iatrogenia ocorrido nas práticas psicoterapêuticas e em demonstrar como a abordagem psicanalítica pode oferecer uma via mais segura, com menor potencial iatrogênico para o paciente, por outro lado, deixa de abordar se haveriam outros riscos iatrogênicos presentes no tratamento psicanalítico e, caso afirmativo, quais seriam tais riscos. Tendo em vista o objetivo deste trabalho, de investigar os possíveis riscos e efeitos iatrogênicos em um tratamento psicanalítico, é preciso ir além do proposto por Maleval, pensando em outros pontos de risco iatrogênicos que podem emergir em um tratamento psicanalítico. Tal tarefa será enfrentada no capítulo subsequente, a partir de uma leitura do Seminário 12 de Lacan. 


\section{CAPítulo 6 - O Potencial IATRogênico da PSiCANÁlise}

\section{A Formalização da Práxis Psicanalítica em Lacan}

No capítulo anterior foi feito um percurso a partir da questão do uso feito do poder nas psicoterapias, como eixo norteador para uma distinção entre psicoterapias e psicanálise, visando identificar em que a consiste a especificidade da prática psicanalítica, se configurando como uma práxis com características singulares. Mas se reconhecemos a psicanálise como uma práxis singular, que não pode ser reduzida aos preceitos e objetivos das psicoterapias, de que modo podemos então pensar a questão das iatrogenias na psicanálise?

No capítulo 4 deste trabalho, foram apresentados resultados encontrados na literatura para o tema da iatrogenia no campo das psicoterapias. Porém, se aceitamos a distinção entre os campos da psicoterapia e da psicanálise, coloca-se em cheque a possibilidade de que as pesquisas realizadas no campo da psicoterapia possam ser aplicadas de maneira direta ao campo psicanalítico. A compreensão acerca da iatrogenia no campo das psicoterapias segue os preceitos desse campo. Já a prática psicanalítica, por sua especificidade, justifica a necessidade de pensar a questão do potencial iatrogênico de um modo coerente com os pressupostos de sua prática e, portanto, não coincidentes com o que é encontrado no campo das psicoterapias. Faz-se necessária outra via de abordagem, que permita configurar um modo de investigação alinhado às especificidades do campo psicanalítico.

A fim de possibilitar essa via de pesquisa no campo psicanalítico, entendemos que, primeiramente, seria necessário conduzir uma investigação acerca do modo de funcionamento da prática psicanalítica e de quais seriam as operações envolvidas em uma análise para que, a partir disso, seja possível eventualmente localizar as possíveis hipóteses de iatrogenia em seu interior. 
Assim sendo, para avançar na investigação acerca do potencial iatrogênico da psicanálise, será apresentado e discutido neste capítulo o modelo apresentado por Lacan em seu Seminário 12, Problemas Cruciais para a Psicanálise (Lacan, 1964-65/2006), no qual Lacan coloca como objetivo delimitar os requisitos essenciais para caracterizar a prática do psicanalista ou, em suas palavras: “...gostaria que continuássemos hoje avançando naquilo que é o problema crucial. Procuramos propor uma forma e, para ser mais preciso, uma topologia essencial à práxis psicanalítica.” (Lacan, 1964-65/2006, pg. 138), ou ainda “...uma tentativa de reunião de condições lógicas onde se coloque a questão do que podemos conceber que seja o que se espera do saber do psicanalista." (Lacan, 1964-65/2006 g. 325)

É certo que há ainda outros momentos da obra lacaniana em que é retomado esse esforço de caracterização da práxis psicanalítica. Podemos pensar no Seminário 15 (1967-68, inédito), $O$ ato analítico, com as construções em torno do conceito de ato analítico, ou ainda o Seminário 17 (Lacan, 1969-70/1992), O avesso da psicanálise, com a teoria dos quatro discursos. Contudo, acreditamos que é no modelo do Seminário 12 que se mostra de modo mais detalhado a dinâmica dos elementos envolvidos na prática psicanalítica e as operações possíveis ao analista, a partir destes elementos.

Além disso, é insistente também nesse Seminário 12 a preocupação de Lacan com a responsabilidade do analista no exercício de sua prática, bem como os riscos de uma prática mal conduzida. Lacan destaca justamente o modo como a prática clínica, por sua relação com o poder, estaria sujeita também a erros em sua condução, o que traz implicações diretas para a questão da responsabilidade assumida pelo analista ao conduzir um tratamento. Assim, a importância de investigar quais seriam os fundamentos dessa prática psicanalítica se justifica também pelo interesse em orientar essa posição responsável assumida pelo analista.

Vimos no capítulo anterior as referências de Lacan acerca da relação entre a prática psicanalítica e o exercício de um poder o que, como consequência, representa risco de erros em sua condução. Mas, como visto também no capítulo anterior, na relação entre poder e psicanálise, trata-se de não permitir que se reduza a prática psicanalítica apenas a um exercício de poder. Ou seja, isso não significa dizer que não 
cabe ao analista considerar os modos como a questão do poder atravessa sua prática, não apenas no sentido do poder que exerce sobre seu paciente, mas também no sentido do paciente em relação ao analista e indo além para considerar até mesmo outros atravessamentos de poder relacionados à sua prática. Foi neste sentido que destacamos que a responsabilidade do analista envolve a possibilidade de conduzir o tratamento de um modo que seja capaz de reconhecer e estar atento às dinâmicas de poder que atravessam o tratamento para, a partir daí, realizar operações que possam promover incrementos na liberdade do sujeito, em sua relação com seu desejo.

Nesta montagem, a responsabilidade do analista só pode ser pensada a partir de uma investigação que tome esse jogo de poder como campo de análise e que tenha no horizonte a liberdade do sujeito. Para isso, é necessário reconhecer o sujeito enquanto parte desse jogo, envolto também na disputa de poder e capaz de oferecer resistência. Trata-se, então de perquirir qual estatuto é conferido a este sujeito que busca a análise.

Uma maior clareza acerca do estatuto desse sujeito, e de suas implicações para o tratamento, é o ponto de partida para fornecer algum tipo de possibilidade de redução do risco mencionado por Lacan, de que o analista se considere como benfeitor quando na verdade comete um erro na condução do tratamento, exercendo seu poder no sentido de uma dominação e falhando em sua responsabilidade com o paciente. Não à toa, a questão do ser do sujeito é colocada como um dos principais temas desse Seminário 12, em sua relação também com a responsabilidade do psicanalista:

“A ontologia do sujeito - e qual é a ontologia do sujeito, a partir do momento em que há inconsciente? -, é sobre isso que tentarei este ano traçar para vocês as linhas. Isso tem consequências não somente no nível da crítica como se diz, mas da responsabilidade do psicanalista, termo tão difícil de evocar no contexto da sociedade psicanalítica." (Lacan, 1964-65/2006, pg. 227)

Assim, o modelo proposto neste Seminário 12 para formalizar a prática psicanalítica tem como base uma discussão profunda acerca do estatuto do sujeito, tendo como mirada a questão da responsabilidade do analista na condução do 
tratamento. Neste capítulo, então, será apresentado esse modelo para, em seguida, buscar situar os possíveis riscos de erros ou iatrogenias do tratamento psicanalítico.

\section{CONTEXTo HistóRICO do SEMINÁRIO 12 DE LACAN}

As aulas do Seminário 12, foram oferecidas nos anos de 1964 e 1965, e a escolha de Lacan pelo tema a ser tratado ao longo desse ano de seu Seminário tem relação próxima com o contexto histórico enfrentado por Lacan na época.

Ao avaliarmos hoje a história do movimento psicanalítico na França, vemos que ela não contraria a tendência geral do movimento em outros países, embora apresente características próprias, ao introduzir elementos conceituais que vão determinar o aparecimento de uma nova época para a teoria e a prática da obra freudiana na França e no mundo. Nos anos do pós-guerra, a Sociedade Psicanalítica de Paris (SPP, fundada em 1921) estava fortemente apoiada nas lideranças de Sacha Nacht, Daniel Lagache e Jacques Lacan. Já nessa época, circulavam críticas à Lacan por conta de seus métodos de trabalho que não seguiam as disposições da IPA, especialmente no tocante à duração das sessões, com Lacan adotando sessões de duração variável. Quando Jacques Lacan é nomeado diretor do instituto da SPP, a situação se torna insustentável, agravando uma crise que desembocará na primeira "cisão" do movimento psicanalítico francês, cisão dentro da primeira sociedade francesa de psicanálise. Em 1953, a crise culminaria em uma cisão da SPP, com a saída de Lagache e Lacan para fundação de uma nova escola, a Sociedade Francesa de Psicanálise (SFP, 1953-1963).

Contudo, ao se separarem da SPP, os membros da SFP viam ameaçada também sua condição de filiados à IPA, dando inicio a um longo processo de negociações com a diretoria da IPA visando possibilitar a filiação também dos membros da SFP. Os questionamentos aos métodos lacanianos se intensificavam, particularmente quanto à questão da duração das sessões. As negociações chegam ao fim com um acordo: os membros da SFP que quisessem filiar-se à IPA poderiam fazê-lo, contudo, Jacques 
Lacan e Françoise Dolto seriam forçados a abrir mão de sua condição de analistas didatas.

Assim, dez anos depois da primeira cisão, em 1963, um momento decisivo para toda história do movimento psicanalítico, Lacan é expulso da Associação Internacional de Psicanálise, o que veio, posteriormente a chamar de sua "excomunhão". Um ano mais tarde, a SFP é dissolvida e Lacan, por meio de seu Ato de Fundação (Lacan, 1964/2003), funda sua escola, a Escola Freudiana de Paris EFP), acompanhado por discípulos, como Françoise Dolto, Serge Leclaire e Octave Mannoni. Com tal mudança, Lacan se viu forçado a alterar também o local de seu ensino, sendo acolhido na École Normale Supérieure (ENS), graças à ajuda de Louis Althusser, possibilitando que Lacan desse continuidade ao seu ensino. Como afirma Roudinesco (1988, pg. 382): “A partir de dezembro de 1963, uma nova força emerge no interior da terceira geração. De maneira ainda confusa, ela tende a se autodesignar pelo nome de movimento lacaniano".

Essa ruptura promoveu efeitos em Lacan que passou a ter que se haver com questões acerca do modo de constituição e organização do que seria sua escola e sua proposta para formação do psicanalista e transmissão da psicanálise. Isso se faz sentir nos Seminários subsequentes apresentados por Lacan. Trata-se de um período intermediário da obra de Lacan, em que seu pensamento já se mostrava mais amadurecido e se apresentava a necessidade de responder à sua exclusão da IPA e perda da condição de analista didata. Foi necessário pensar qual seria a maneira adotada em sua escola para formação de psicanalistas, quais seriam os mecanismos e princípios adotados para transmissão desse ofício, bem como para articular e estabelecer aquilo que seria a base de seu ensino, as premissas fundamentais da teoria e prática psicanalíticas no âmbito de sua escola.

Lacan buscou responder a esses objetivos nos Seminários subsequentes. A partir de seu Seminário 11(1963-64/1985) são abordados temas relacionados aos fundamentos essenciais da prática psicanalítica, o que fica claro já nos títulos colocados para esses Seminários: os quatro conceitos fundamentais da psicanálise; problemas cruciais para psicanálise; o objeto da psicanálise; a lógica do fantasma. 
Neste sentido, a nota preliminar à tradução brasileira do Seminário 12 destaca este momento de transição vivida por Lacan e o impacto na sua escolha do tema de trabalho para este Seminário:

"Há muitos anos Lacan era o objeto de negociatas por parte da I.P.A., junto a um certo número de alunos seus, para fazê-lo se calar. $\mathrm{O}$ apoio que the fora trazido no ano precedente por várias personalidades para obter-lhe a sala de conferência da Escola Normal Superior foi ao mesmo tempo um reconforto e um estímulo. Mas no início desse novo ano, uma certa lassidão o tinha afetado. Jakobson, a quem ele participava seus embaraços, lhe tinha respondido: 'Quando tu não sabes o que fazer, intitulas teu curso problemas fundamentais'” (Lacan, 1964-65/2006, pg. 9)

Cumpre destacar que Lacan menciona algumas vezes durante o ano que, originalmente, sua ideia era de que o tema daquele ano do Seminário fossem as posições subjetivas, ideia que reconhecidamente abandonou, após aconselhar-se com Jakobson. Porém, apesar da mudança, como destaca também Lacan, o tema se fez presente ao longo do curso, em que Lacan discute de modo extenso justamente a questão acerca do estatuto do sujeito na prática psicanalítica, as posições subjetivas sendo discutidas especialmente nas últimas aulas do Seminário.

Contudo, apesar de temas tão importantes para a práxis psicanalítica, tais Seminários compõe também um período dos menos trabalhados e estudados na obra lacaniana. Não apenas por questões teóricas, mas também por questões políticas, tais Seminários não foram ainda estabelecidos e publicados oficialmente, restringindo o acesso a essa parte da obra lacaniana. Contudo, podem ser encontradas publicações e traduções não oficiais e em português para estes Seminários.

Outro ponto de destaque acerca dos Seminários deste período de fundação da EFP é que Lacan busca promover um esforço para conferir maior voz a seus alunos e membros da escola. Em especial, neste Seminário 12, Lacan adota um procedimento inédito, repartindo os encontros do ano em duas modalidades: os seminários abertos, em que Lacan dava suas aulas para o público interessado em acompanhar suas lições; e os 
seminários fechados, voltados para um público mais restrito, em que os próprios alunos tomavam a palavra para fazer apresentações sobre temas de interesse, discutindo textos, casos clínicos e outras questões relevantes para a pesquisa desenvolvida naquele ano. Assim, pessoas como Jacques-Alain Miller, Serge Leclaire, Moustapha Safouan, dentre outros, participam ativamente dos seminários fechados, trazendo suas contribuições ao debate.

Apesar de ser chamado de seminário fechado, Lacan não visava com isso impedir o acesso de pessoas aos temas discutidos. Segundo registros da época e como colocado pelo próprio Lacan, o objetivo não era de fechar as portas ou excluir ninguém, mas sim de permitir que Lacan pudesse se aproximar e conhecer as pessoas que se interessavam em ouvir o que tinha a dizer, além de buscar promover um maior engajamento por parte dos participantes. Desse modo, para participar desse seminário fechado, bastava que a pessoa fizesse uma solicitação expressa à Lacan, pedindo para participar e se comprometendo ao compromisso desejado para participar das atividades. Neste sentido, Lacan afirma:

"E essa é uma das razões pelas quais eu quis instituir a quarta-feira fechada de meu seminário. Para falar propriamente, é ela que dará novamente um sentido a essa palavra seminário, na medida em que, espero, alguns queiram aqui contribuir.(...) É para essa ocasião que, tendo pedido que me solicitassem a entrada, o que não é feito para ser recusado, mas exatamente ao contrário. (...) A demanda que fiz não é, portanto, destinada, se posso dizer, a fazer um ato de fidelidade, a curvar a cabeça sob não sei qual arco à entrada, é um desejo de conhecer a quem falo e em que medida posso ter que responder mais precisamente à sua questão." (Lacan, 196465/2006, pg. 79)

Ou ainda:

"Não obstante, se eu quis que me demandassem para vir aqui, é para me colocar também em posição de lhes demandar aqui a darem suas provas do que é exigível em um certo círculo mais restrito, para que este ensinamento tome valor. (...) Quero aqui 
pessoas que estejam implicadas na sua ação nisto que comporta essa mudança essencial da motivação ética e subjetiva que é, que introduz no nosso mundo, a análise." (Lacan, 1964-65/2006, pg. 114)

Assim, temos o funcionamento deste Seminário 12, que visa tratar dos Problemas cruciais para a psicanálise. Como já mencionado, um dos principais objetivos colocados por Lacan é de abordar o problema da possibilidade de elaboração de uma formalização que possa dar conta de organizar em que consiste a prática psicanalítica, quais os processos que operam no curso de um tratamento psicanalítico. Para tanto, Lacan retoma uma série de temas que já haviam sido abordados anteriormente em sua obra, numa espécie de resumo e reorganização do que seriam os principais aspectos envolvidos na prática psicanalítica.

Sobre esta proposta de Lacan para oferecer uma formalização da prática psicanalítica neste Seminário 12, Dunker (2015) afirma:

"Esse resumo, essa retomada vai apontar para três dimensões dessa tentativa de formalização do conjunto da prática clínica que é objetivo desse seminário, objetivo declarado de encontrar um modelo para o que a gente faz, o que acontece no conjunto do tratamento psicanalítico. (...). Lacan nesse seminário tenta encontrar um modelo que consiga sintetizar, formalizar, todas operações fundamentais que estão envolvidas neste percurso. Então considerem o seguinte, é um modelo extremamente redutivo, que não vai dar um bom retrato da viagem, seus meandros, seus impasses, sua fenomenologia. Mas o objetivo de encontrar um mapa geral, espécie de guia topológico."

Temas como o conceito de sujeito e sua relação com o significante, a questão do ser do sujeito e da identificação, a topologia, o corte e a sutura, a relação entre o saber e a verdade, bem como os temas do real e do sexo, compõem os elementos principais das articulações promovidas neste Seminário. É a partir desses temas que Lacan pretende então abordar as possibilidades de estabelecimento de quais seriam os requisitos mínimos para a prática psicanalítica, e a possibilidade de formalização dessa prática. 
Esse problema é enfrentado mais diretamente a partir da lição XVII deste Seminário (aula de 5 de maio de 1965), se estendendo também pelas duas aulas subsequentes. O ponto de partida é a questão do sujeito e qual lugar pode ser dado a este sujeito no tratamento psicanalítico.

\section{Qual Estatuto Para o Sujeito no Tratamento Psicanalítico?}

Ao longo deste Seminário 12, Lacan aborda a questão do ser do sujeito, tomando para isso referências em temas da lógica e da filosofia. Em particular, os desenvolvimentos no campo da lógica e da matemática com Frege (1884/1983) acerca do conceito de número (e, de modo destacado, o conceito de zero), bem como dos campos da linguística e da filosofia clássica, com o questionamento acerca de qual estatuto pode ser dado ao nome próprio e os efeitos da função de nomeação para o sujeito. Tais temas são discutidos sob o prisma da identificação e do modo como seria possível pensar a relação do sujeito com seu próprio ser, considerando o sujeito em sua relação com a linguagem e com o saber.

Esses desenvolvimentos irão culminar numa definição de significante tomada por Lacan como paradigma central para a discussão sobre o sujeito neste Seminário 12 (Lacan, 1964-65/2006, pg. 326), e que configuraria uma das "duas posições fundamentais do que lhes ensino quanto à nossa lógica, a lógica de nossa prática psicanalítica, a lógica implicada pela existência do inconsciente”. Tal definição é a de que "O significante é o que representa o sujeito para um outro significante" (Lacan, 1964-65/2006, pg. 326) . De tal definição podem ser extraídas uma série de implicações que podem embasar a possibilidade de uma articulação acerca da prática psicanalítica.

Uma primeira derivação importante destacada por Lacan é a importância da diferenciação entre signo e significante, sendo o signo aquilo que representa alguma coisa para alguém e que, portanto, se aproxima da ideia de sinal e do uso para comunicação, da informação. Isso em oposição ao significante que, como dito, representa o sujeito para outro significante. Nesse sentido, Lacan afirma: 
"O acento colocado aqui na fórmula, o significante representa o sujeito para um outro significante, vocês o observaram, consiste em diferenciar o significante, não do lado do receptor como se faz sempre, e onde ele se confunde com o sinal, mas do lado do emissor, pois se digo que o significante representa o sujeito para um outro significante, é na medida em que o sujeito do qual se trata é aquele que o emite." (Lacan, 1964-65/2006, pg. 294).

O sujeito aqui tomado em sua relação com o significante e, consequentemente, com a falta, efeito de um descompasso neste processo de representação, em que o significante aparece como representante do sujeito. Por um lado, é por meio da articulação significante, enquanto representante do sujeito, que é possível emergirem os efeitos de sentido e toda significação possível. Por outro lado, tal processo relega o sujeito - e seu desejo - a esta posição de resíduo, a este momento de falha e de oscilação entre significantes. Seguindo com Lacan:

"Se é verdade que há a falha (...) se é verdade que essa representação do sujeito, que esse de quem o significante é seu representante, é o que se presentifica no efeito de sentido e que haja aí, entre isso e tudo o que se constrói como significação, essa espécie de campo neutro, de falha, de ponto de acaso, o que vem se encontrar não se articula absolutamente de maneira obrigatória." (Lacan, 1964-65/2006, Pg. 23)

Essa falha e seus efeitos sobre toda significação resultam da inferência de que, se o significante é o que representa o sujeito para um outro significante, temos aí também que "o significante determina o sujeito, determinando-o, ele o barra e esta barra quer dizer por sua vez vacilação e divisão do sujeito." (Lacan, 1964-65/2006, pg. 291). Assim, nesse efeito de representação do sujeito pelo significante, mas que ao mesmo tempo barra o sujeito, é que se estabelece o efeito de repetição e alternância em que o sujeito e seu desejo, em sua singularidade, apenas podem emergir nos vacilos do significante: "ao significante representando o sujeito numa função de alternância, de vel, de 'ou bem isso, ou bem aquilo', ou bem o significante que representa, ou bem o sujeito e o significante que desvanece." (Lacan, 1964-65/2006, Pg. 343). 
É nesse ponto que as referências de Lacan ao conceito de zero em Frege e à função do nome próprio na filosofia clássica ganham todo seu relevo: que o sujeito, em sua relação com a falta, e determinado pelo significante, se afasta da lógica de uma conotação ou classificação ou referência direta e universal ao ser do sujeito, mas, pelo contrário, se refere a algo de singular, particular e irredutível da dimensão do sujeito que se articula na falha da articulação significante. Sobre isso:

"Que esse sujeito se situe, se caracterize essencialmente, como sendo da ordem da falta, é o que tentei fazer-lhes sentir mostrando, nos dois níveis, do nome próprio por um lado, da numeração por outro, que o estatuto do nome próprio não é possível de articular, não como uma conotação cada vez mais aproximada disso que chegaria, na inclusão classificatória, a se reduzir ao indivíduo, mas ao contrário, como o preenchimento de alguma coisa de uma ordem outra, que é o que, na lógica clássica, se opunha à relação binária do universal com o particular, como alguma coisa terceira e irredutível a seu funcionamento, a saber, como o singular." (Lacan, 1964-65/2006, pg. 325)

Assim, com o recurso à lógica moderna da numeração e, mais especificamente, ao conceito do próprio zero, Lacan encontra em Frege a possibilidade de conferir uma fundamentação desse estatuto singular do sujeito. Tal concepção, segundo Lacan (196465/2006, pg. 327) "nos dá acesso à verdade e à prática analítica, (...) e que essa lógica pode convocar, que poderia convocar, se tenho êxito, a formalizar o desejo.”. E aqui temos outro ponto de grande importância para os desenvolvimentos subsequentes: a relação entre sujeito e verdade e as implicações dessa relação para que se possa pensar o desejo do sujeito, enquanto desejo determinado pelo jogo significante.

A partir desta relação com a verdade, pode-se extrair outra posição colocada por Lacan como fundamental para a lógica da prática psicanalítica e o estatuto do sujeito no tratamento. Se tomamos essa premissa do significante, enquanto aquilo que representa o sujeito para outro significante, qual deve ser então o estatuto do saber em sua relação com o sujeito e com a verdade? Tal questão se coloca como fundamental devido ao argumento de que a própria possibilidade e estabelecimento de uma análise, 
possibilidade de início de um tratamento, está em um momento inicial de suposição de saber, ou seja, em que o paciente supõe ao analista um saber, colocando-o na posição de sujeito suposto saber. Assim, a segunda proposição fundamental colocada por Lacan neste Seminário (Lacan, 1964-65/2006, pg. 326): “O que quer dizer, em nosso campo, no campo que a psicanálise descobre, o que quer dizer a fórmula, o sujeito suposto saber?"

Lacan propõe então uma discussão acerca da própria concepção de saber ao longo da história da ciência e, posteriormente, o modo como a questão do saber é subvertida no campo psicanalítico. Retomando a discussão colocada por Descartes ao propor seu cogito, Lacan retoma a questão do saber na história da Ciência. Amparada pelo argumento do cogito cartesiano, a ciência avança como uma acumulação contínua de informações, um saber que pode ser armazenado, acumulado, somado. Porém, para que isso se sustente, é necessária uma concepção de saber como nada mais do que um agrupamento de significantes. Desse modo, o que acaba se perdendo neste processo é justamente a questão da verdade e do real. Neste sentido, Lacan afirma:

"E o que não se vê é que esse real do sábio, a saber, o que é um saber, é exatamente um corpo de significantes e absolutamente nada mais. Se a noção de informação pode tomar essa forma anônima que permite qualificá-la em termos do que se chama bit, é na medida em que a armazenagem, o storage de elementos de informação se basta por si mesmo a nossos olhos para constituir o que se chama um saber... (...) Na necessidade mesma do saber, da articulação significante, há essa contingência de não ser senão uma articulação significante, uma fechadura montada" (Lacan, 196465/2006, pg. 334)

Assim, trata-se do lugar do sujeito nesta relação com o saber, que posição para o sujeito neste saber da ciência, passível de ser acumulado? Se, por um lado, temos que o significante é o que representa o sujeito para outro significante e, por outro lado, que esse significante, ao mesmo tempo, barra o sujeito, como então pensar o lugar do sujeito num saber científico que se articula como um corpo de significantes que se acumula? 
O que nos mostra a descoberta freudiana é justamente a limitação desse saber enquanto mera composição significante, é a impossibilidade de articulação de um saber completo e universal, sem falhas. Se é possível pensar um sujeito em relação com o saber é justamente no ponto em que esse saber falha, em que há uma falta no saber. Neste sentido:

"é na ambiguidade da relação de um sujeito com o saber, é no sujeito enquanto ele falta ainda ao saber, que reside para nós o nervo, a atividade da existência de um sujeito. É exatamente por isso que não é enquanto suporte suposto de um conjunto harmonioso de significantes do sistema que o sujeito se funda, mas na medida em que em algum lugar há uma falta que eu articulo para vocês como sendo a falta de um significante, porque é essa articulação que nos permite reunir da maneira a mais simples a articulação freudiana para dela desprendermos a força essencial." (Lacan, 1964-65/2006, pg. 341)

Assim, trata-se, na descoberta freudiana, da relação do sujeito com um nãosaber, um saber ao qual o sujeito se recusa a ter acesso.

"O que quer dizer o inconsciente, é que o sujeito recusa um certo ponto de saber, é que o sujeito se designa deliberadamente o não saber, é que o sujeito se institui - esse é o avanço em que a articulação freudiana se enriquece através de que eu designo à margem concernente à relação do sujeito com o significante - é que o sujeito se institui por um significante rejeitado, verworfen, por um significante do qual não quer saber nada." (Lacan, 196465/2006, pg.342)

Há assim, um ponto de falha no saber, um impossível de saber, que se encontra na própria fundação do sujeito, um real que não se inscreve e que Lacan indica como o impossível da relação sexual:

“...mas o masculino e o feminino, nós não sabemos o que é. E Freud o reconhece, o afirma. 
O que é? Para que o saber, penso, o saber capaz de dar conta dele mesmo, o saber que sabe articular o sujeito - não há outro para dar seu estatuto ao inconsciente, o inconsciente não quer dizer nada fora dessa perspectiva - o que há nesse saber de especial para que à aproximação desse saber funcione, e de uma maneira unilateral, a saber, no sentido de puro eclipse, da desaparição do significante, não apenas do Verwofen fundador do sujeito mas o Verdrangt, recalcamento de tudo o que pode aproximá-lo mesmo de longe e que testemunha a presença do sujeito no inconsciente, onde o sujeito do inconsciente é o sujeito que evita o saber do sexo?" (Lacan, 1964-65/2006, pg. 344)

Impossível de saber, uma falta no saber, um significante faltante, sendo daí que se articula o sujeito em sua singularidade, de tal modo que o "sujeito do qual se trata não é senão o sujeito em sua relação com o significante faltante.”. (Lacan, 196465/2006, pg. 347). Ou, como coloca Dunker (2015): "sujeito tomado então, enquanto sujeito dividido, em sua divisão entre fala e língua, entre significante e significado, entre eu e outro, entre enunciado e enunciação, entre desejo e demanda, enfim, o sujeito em sua gramática de divisões.”. Esse sujeito dividido estaria fundado justamente na certeza do impossível, como mostra formalização utilizada por Lacan:

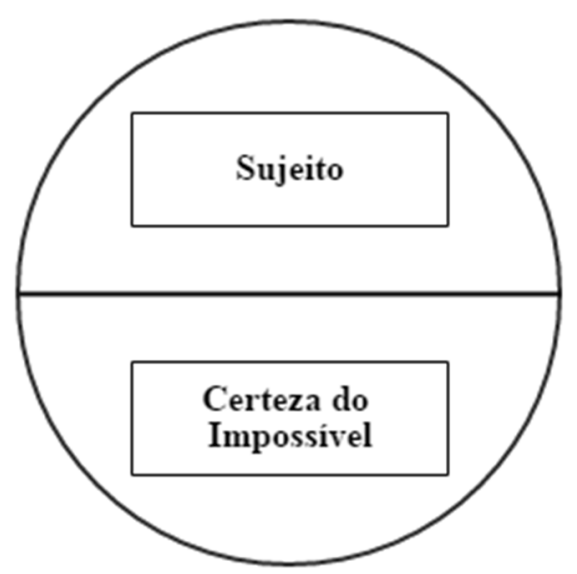

Figura 3: Representação do sujeito sustentado pela certeza do impossível

Essa representação, com uso da barra colocando um elemento acima e outro abaixo, recorrente na obra lacaniana, é aqui utilizada para representar o processo de 
constituição do sujeito, com a ideia de que algo (abaixo da barra) é suprimido, negado, para permitir o estabelecimento de algo (acima da barra) que se constitui e que se evidencia na realidade. Assim, é a certeza do impossível que sustenta este sujeito. E esta certeza do impossível, como vimos, se relaciona à perda de um significante, um significante originalmente foracluído. Trata-se de um modo diverso de pensar a constituição subjetiva, diferente de propostas anteriores na obra lacaniana.

A ideia aqui é propor um modo unificado para constituição subjetiva, invariável, independentemente da estrutura do sujeito. Assim, a princípio, com o diagnóstico estrutural, tínhamos também a proposta de modos específicos de constituição do sujeito, conforme a estrutura (recalque para a neurose, foraclusão para a psicose e recusa para a perversão). Já neste momento do Seminário 12, temos a sugestão de que, independentemente da estrutura, haveria sempre uma foraclusão fundante do sujeito, constitutiva. Sendo que apenas em um segundo momento é que este sujeito estabeleceria sua relação com a linguagem a partir de uma das saídas mencionadas anteriormente (recalque, foraclusão, recusa). É essa a posição de Dunker (2015):

\begin{abstract}
"Neste Seminário 12 temos uma proposta que se aproxima mais de um modelo unificante, em que o sujeito, qualquer que seja sua estrutura, se constitui não necessariamente pelo recalque, mas sim pela foraclusão. Um momento inaugural de foraclusão, de um significante rejeitado, significante que é excluído do simbólico, que seria comum à todas estruturas, como momento de constituição subjetiva. Desse modo, o que teríamos de diferença entre as estruturas, se daria em um segundo momento, nas relações que o sujeito irá estabelecer com a linguagem e, aí sim, para cada estrutura uma saída particular (recusa/recalque/foraclusão).”
\end{abstract}

Assim, na referência ao sujeito adotada neste Seminário e neste modelo de formalização proposto por Lacan, não se trata do sujeito em sua estrutura, mas do sujeito enquanto aquilo que se estabelece a partir dessa foraclusão inicial de um significante, sendo que as variações posteriores estariam do lado do fantasma, dos mecanismos de defesa e das relações com a linguagem. 
Ao longo desta elaboração acerca do estatuto do sujeito, emergem três elementos que são destacados por Lacan como vitais para a articulação da prática psicanalítica. São eles: o sujeito, o saber e o sexo. É a partir dessa tríade que, na aula de 19 de maio de 1965, Lacan apresentará sua formulação do essencial da prática psicanalítica, tomando esses elementos para articulá-los em uma representação da prática psicanalítica à semelhança de um jogo.

\section{A Prática Psicanalítica como um Jogo}

Na Lição XIX de seu Seminário 12, Lacan oferece então esta sugestão da psicanálise como uma prática que se estrutura de modo semelhante a um jogo. Uma prática que pode ser formalizada como um jogo, jogo organizado a partir de três "jogadores", que são os três elementos mencionados anteriormente: o sujeito, o saber e o sexo. Três faces diversas de um mesmo sujeito, mas que são consideradas como elementos distintos para esse jogo. Mas como se organizaria este jogo?

No início da lição, Lacan se refere a esse jogo por meio de uma analogia com o jogo da murrinha (ou morra). Segundo a definição oferecida em nota de rodapé do Seminário 12 (Lacan, 1964-65/2006, pg. 360), trata-se de: “jogo de azar no qual duas pessoas mostram rápida e simultaneamente um certo número de dedos, estendidos, gritando um número. Ganha aquele que dá o número certo de dedos.”. Um jogo que se assemelha ao jogo do "palitinho". A vantagem desta analogia é que ela é composta por uma dimensão de aposta, em que o jogador faz um lance, sabendo o número que tem em suas mãos e tendo que adivinhar o número escolhido pelo adversário. Essa ideia retorna em outro trecho da lição, mas em referência a um jogo semelhante jogado com bolinhas de gude:

"Aquele que tem as bolas de gude sabe se seu número é par ou ímpar. Pouco importa que ele o saiba ou não, aliás há em sua mão um saber; e a paixão do jogo surge por isso, que, à frente, eu me 
instituo como sujeito que vai saber." (Lacan, 1964-65/2006, pg. 354)

Tal referência reaparece também no Seminário 24 (Lacan, 1976). Segundo a versão disponível no Staferla ${ }^{9}$, a descrição feita por Lacan do jogo de Murra se aproxima de algo semelhante ao jogo de palitinho, em que cada jogador tem um determinado número de palitos consigo e deve escolher quantos destes palitos ele irá ocultar em sua mão. Após cada jogador ocultar um determinado número de palitos em suas mãos, cada jogador deve dar um palpite sobre qual o total de palitos ocultos, somando-se os palitos de todos os jogadores. $\mathrm{O}$ jogador que acerta o número total tem o direito de eliminar um de seus palitos e o jogo acaba quando algum jogador consegue zerar seus palitos. Este seria o jogo de Murra.

Porém, apesar dessas referências, na maior parte da lição a analogia sustentada é entre o jogo psicanalítico e algo que se aproxima mais do jogo do pedra, papel e tesoura (ou jo-ken-po), onde três elementos interagem, estabelecendo uma relação de dominância circular "onde tesoura, pedra e papel se ganham em círculo indefinidamente - pedra quebrando tesoura, papel envolvendo pedra, tesoura cortando papel" (Lacan, 1964-65/2006, pg. 349).

Fazendo a correspondência dessa analogia para o jogo psicanalítico, o que resulta, segundo Lacan:

"O sujeito se indetermina no saber, o qual pára diante do sexo, o qual confere ao sujeito essa nova espécie de certeza por onde seu lugar de sujeito, sendo determinado e só podendo sê-lo pela experiência do cogito, com a descoberta do inconsciente, pela natureza radicalmente, fundamentalmente, sexual de todo o desejo humano, o sujeito toma sua nova certeza, aquela de tomar sua morada na pura falha do sexo." (Lacan, 1964-65/2006, pg. 349)

Lacan destaca especialmente esta dinâmica de relação de dominância circular, dada para representar o modo como o próprio sujeito se reengendra, em sua relação com

\footnotetext{
${ }^{9} \mathrm{http} / / / \mathrm{staferla.free.fr/}$
} 
o saber e com o sexo, no âmbito da operação analítica. Cabe, então, esmiuçar cada um dos pontos dessa relação de dominância circular, a fim de esclarecer de que se trata no jogo psicanalítico.

Para engendrar a articulação entre esses três termos, Lacan nos relembra ainda a importância de um quarto elemento, central na prática psicanalítica: a questão da verdade. Retomando a lógica clássica, desde as articulações de Aristóteles sobre a questão da contingência da verdade, Lacan mostra como a ciência se funda numa determinada relação entre verdade e saber, em que a verdade fica em suspenso, aguardando sua confirmação a partir da possibilidade de articulação em formas de saber. É apenas ao se articular como saber que a verdade se confirmaria, colocando a questão acerca das possibilidades de determinação da verdade enquanto necessária e não apenas contingencial. Como coloca Lacan (1964-65/2006, pg. 350): “Onde está esse saber? ali onde tem seu estatuto, onde o constituímos, não inconsciente, mas externo a nós, ele se funda na ciência. Onde estava a verdade antes do saber? Está em Aristóteles. É o estatuto da contingência da verdade antes que ela se confirme em saber". Ou seja, uma concepção em que a confirmação da verdade está submetida a seu estabelecimento como um saber.

Contudo, é com a descoberta freudiana do inconsciente que emerge uma solução para essa problemática, a questão da orientação da verdade. A articulação freudiana mostra uma relação diversa entre verdade e saber, com uma inversão, na qual o saber não pode se constituir, se a verdade está em suspenso. Aqui a verdade não mais estaria em articulação ou visando um saber, mas sim em relação ao ser do sujeito ou, mais especificamente para a psicanálise: o sexo. Sexo enquanto marca do que é impossível ao saber, impossível de dizer ou, ainda, "O sexo, em sua essência de diferença radical, permanece intocado e se recusa ao saber" (Lacan, 1964-65/2006, pg. 351). Articula-se então uma nova relação entre verdade e saber, a partir do sexo, ao qual o saber não alcança, e que produz efeitos também para o terceiro elemento da relação, o sujeito. É a partir desta certeza de um saber impossível, desta falta no saber, marcada pelo sexo, que se torna possível a emergência do sujeito, enquanto resto dessa falta no saber, deste impossível do sexo. 
Neste sentido Lacan afirma sobre a verdade e o sexo:

"A verdade está no dizer sobre o sexo e é porque ele é impossível isso está no texto de Freud - que a posição do analista seja impossível, é por isso, é porque impossível dizê-la por inteiro que dela provém essa espécie de suspensão, de fraqueza, de incoerência secular no saber, que é propriamente aquela que Descartes denuncia e articula para dela desprender sua certeza sobre o sujeito, em que o sujeito se manifesta como sendo justamente o sinal, o resto, o resíduo dessa falta de saber, por onde ele reúne o que o ligou, o que se recusa ao saber, no sexo; a que o sujeito se acha suspenso sob a pura forma dessa falta, a saber, como entidade dessexuada." (Lacan, 1964-65/2006, pg. 351)

Há assim, como já visto anteriormente, um ponto de saber inconsciente e inacessível ao sujeito, um saber ao qual o sujeito se recusa a ter acesso, um significante rejeitado, foracluído (verworfen), sendo justamente a partir dessa recusa a um saber que se institui o sujeito. Segundo Lacan:

"Um saber, então, se refugia em algum lugar, nesse lugar que nós podemos chamar (...) num lugar de pudor original, em relação ao qual todo saber se institui em um horror inultrapassável a respeito desse lugar onde jaz o segredo do sexo." (Lacan, 1964-65/2006, pg. 351)

O saber inconsciente, trata-se de um saber que pressupõe um sujeito que o sabe, um sujeito indeterminado, ou seja, o amparo em uma suposição de saber. É assim que opera o sintoma, em referência a um saber que ainda não se sabe mas ao qual está presumido um sujeito. Contudo, mesmo esse saber inconsciente esbarra e se estabelece em relação ao impossível de saber colocado pelo sexo:

"O saber do inconsciente é inconsciente nisso, que do lado do sujeito, ele se coloca como indeterminação do sujeito, nós não sabemos em que ponto do significante se aloja esse sujeito presumido saber. Mas por outro lado, esse saber, mesmo inconsciente, está numa referência de interdito fundamental a 
respeito desse pólo que o determina em sua função de saber. Há alguma coisa que esse sujeito... esse saber não deve saber." (Lacan, 1964-65/2006, pg. 351)

Assim, Lacan resume então a relação entre os três termos desse jogo, sujeito, saber e sexo:

"Assim marquei no quadro a figura: com as características que acabo de enunciar, os três polos: do saber enquanto inconsciente, que sabe tudo talvez, exceto o que o motiva; do sujeito que se institui em sua certeza de ser falta em saber; e esse terceiro termo, que é precisamente o sexo, na medida em que, nessa esfera, ele é rejeitado de início, na medida em que, daí resulta aquilo de que não se quer nada saber." (Lacan, 1964-65/2006, pg. 352)

Resumindo essas relações, Lacan apresenta a seguinte representação:

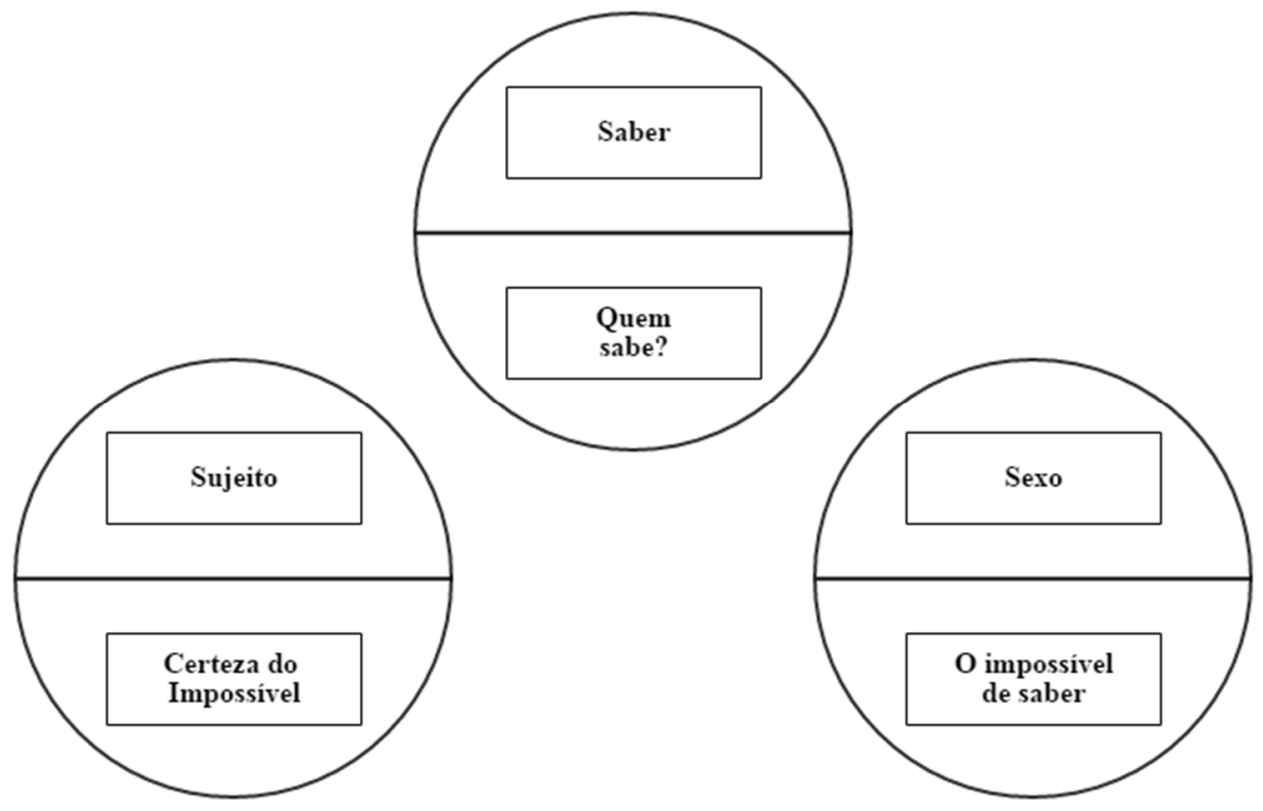

Figura 4: Representação do Sujeito, do Saber e do Sexo, sustentados respectivamente pela certeza do impossível, pelo "quem sabe?" e pelo impossível de saber (Lacan 1964-65/2006, pg. 352)

Colocados aí, então, os três elementos desse jogo psicanalítico e as relações estabelecidas entre eles. Resta ainda esclarecer o porquê da proposta de Lacan de definir este funcionamento como algo comparável ao funcionamento típico de um jogo. Lacan 
fará isso com apoio na teoria dos jogos, como proposta por Von Neumann (1944/1977), extraindo princípios da teoria dos jogos que seriam aplicáveis também ao jogo psicanalítico. "Tentarei, hoje, dizer-lhes como, do ponto de vista da análise, que tem todos os caracteres de um jogo, podemos aproximar o que é desse registro." (Lacan, 1964-65/2006, pg. 353)

Um primeiro ponto destacado por Lacan acerca do jogo é que o jogo se apresenta sempre como uma simplificação e, ao mesmo tempo, um sistema fechado, instituído por uma regra. Essa regra, segundo Lacan, teria o efeito de excluir esse ponto de acesso impossível, aquele marcado pelo impossível de dizer sobre o sexo. Assim, a dinâmica do jogo fica reduzida à circulação entre sujeito e saber, o sujeito que espera seu lugar no saber, numa tensão da relação entre este sujeito e o saber. Porém, este impossível de saber, excluído do jogo pelo estabelecimento da regra, retorna ao jogo e retorna na forma de uma aposta. Como afirma Lacan: "Sob qualquer forma que seja, de um jogo ou das bolas, a realidade que toma seu lugar perde o que, nesse triângulo, nesses três polos, é impossível saber, mas que, rebatido no jogo, porque excluído nesse impossível, torna-se a pura e simples realidade da aposta." (Lacan, 1964-65/2006, Pg. 354)

Esta aposta, Lacan situa numa oposição ao risco, vez que o jogo localiza e dá contornos ao campo das jogadas possíveis, mascarando os riscos, restringindo-os e limitando-os ao campo da aposta. Assim, se a aposta se realiza no âmbito circunscrito pelas regras do jogo, isso ao mesmo tempo reduz suas possibilidades e alcances, distinguindo-o do que seria um verdadeiro risco, vez que no jogo os desfechos possíveis são previstos.

Sobre este ponto, Lacan retoma a teoria dos jogos em Pascal (1918/2000) e a importância da teoria da partilha, ou seja, a ideia de que, a qualquer momento do jogo, é possível realizar uma revisão, uma redistribuição, um reajuste das apostas em jogo, as apostas sendo redivididas conforme as esperanças dos jogadores envolvidos. Assim, a estratégia a ser adotada em um jogo se relaciona a um certo cálculo envolvendo as jogadas possíveis para o próprio jogador, em conjunção com o universo das jogadas 
possíveis para os outros jogadores, visando um lance, uma aposta, que alcance a maior chance de êxito.

Tomando esta definição de estratégia, Lacan utiliza ainda outro conceito da teoria dos jogos, o conceito de ponto de sela, conceito que indica um momento do jogo em que os jogadores alcançam certo equilíbrio em que, mantendo todos sua mesma jogada, poderão alcançar conjuntamente a jogada mais benéfica ou com menor risco de perdas, alcançando um estado de estabilidade no jogo. Segundo Lacan:

"essa teoria dos jogos onde se demonstra que o que se chama estratégia é alguma coisa que nos mostra que - o que é perfeitamente calculável - que num número de casos bastante extenso para que isso dê início a toda elaboração concernente ao exercício dos jogos, num número bastante grande de casos, conhecida a conotação das jogadas possíveis para um jogador com o conjunto das jogadas possíveis para o outro, há um ponto, chamado ponto de sela, como se diz de um cavalo, onde se recorta, como sendo estritamente idêntico, o que devem jogar os dois jogadores para ter juntamente e em todos os casos o mínimo de perda, mostrando que a natureza do jogo está longe de ser pura e simples oposição entre os jogadores, mas, de início, em sua compreensibilidade mesma, possibilidade, ao contrário, de acordo" (Lacan, 1964-65/2006, pg. 354)

Mas como esse ponto de sela se articula ao jogo psicanalítico? Se aceitamos que, em muitos casos, o que se busca na teoria dos jogos é esse ponto de acordo e de cumplicidade entre os jogadores, visando um melhor equilíbrio das apostas, na cena psicanalítica se trata também de buscar uma jogada, uma aposta, entre o sujeito dividido, enquanto sujeito ele mesmo, na relação com seu saber, por um lado, e, por outro lado, o encontro com algo que o remete ao seu próprio ser, enquanto resíduo, ou resto, excluído do saber, falha no saber que o remete à falta inerente ao seu ser, e relativa ao impossível da relação sexual. Dividido entre essas duas facetas, o saber do sujeito e sua falta, a aposta a ser realizada neste jogo se dá então no âmbito do desejo do sujeito, em sua articulação com o objeto $a$. 
"Se é alguma coisa que suporta toda atividade de jogo, é algo que se produz do encontro do sujeito dividido, enquanto ele é sujeito, com esse algo pelo qual o jogador se faz ele mesmo o dejeto de alguma coisa que se jogou noutro lugar, lugar outro a todo risco, o lugar outro do qual ele caiu do desejo de seus pais, e ali precisamente, o ponto do qual ele se desvia indo procurar, para opô-lo, essa relação de um sujeito com um saber. (...) E é por isso que o jogo é a forma propícia, exemplar, isolante, isolável da especificação do desejo; o desejo não sendo mais nada que a aparição dessa aposta, desse $a$ que é o ser do jogador, no intervalo de um sujeito divido entre sua falta e seu saber." (Lacan, 196465/2006, pg. 355)

Isso porque no jogo, ao se estabelecer uma regra, exclui-se o impossível de saber, o sexo, restando apenas um resto, uma versão não ameaçadora e não sexuada do jogo, o que tem efeitos sobre sua relação com a verdade. Uma vez que a regra do jogo, de início, exclui a face do impossível de saber da relação sexual, consequentemente é suprimida também sua relação com a verdade. Desse modo, não há, de partida uma verdade pré-estabelecida, de modo que só poderá ser desenvolvida no próprio curso do jogo. Como afirma Lacan:

"Pode-se perguntar o que é o inconsciente antes que eu o interprete, e o próprio do jogo é que antes que se jogue, ninguém sabe o que vai dar. Está aí a relação do jogo com o fantasma. O jogo é um fantasma tornado inofensivo e conservado em sua estrutura." (Lacan, 1964-65/2006, pg. 355)

Tal ideia pode também ser aplicada ao próprio trabalho do inconsciente e ao jogo da análise, tomando o tratamento psicanalítico como um jogo a ser jogado, de modo que o inconsciente possa ser definido como o jogo antes de ser jogado. Ainda que já existisse inconsciente antes de Freud, não era ainda possível jogá-lo, não havia o dispositivo capaz de articular o inconsciente a um jogo. Esse jogo só é inaugurado com a descoberta de Freud, quando traz á tona uma outra cena, da escuta analítica, da fala em associação livre e a escuta do discurso do paciente, permitindo o trabalho com o inconsciente. Assim, se estabelece a relação entre saber e o inconsciente, sendo que "o 
inconsciente é um saber cujo sujeito permanece indeterminado, no inconsciente. O que ele sabe? Do sexo.” (Lacan, 1964-1965/2006, pg. 357)

Ou seja, assim como o fantasma visa a promover algum tipo de amarração ou sutura entre o sujeito, enquanto sujeito dividido, e sua relação com este resto do impossível da relação sexual, marcado pelo objeto $a$, o jogo, ao estabelecer sua regra também cria a possibilidade de uma articulação possível em face desta relação entre o sujeito e o saber.

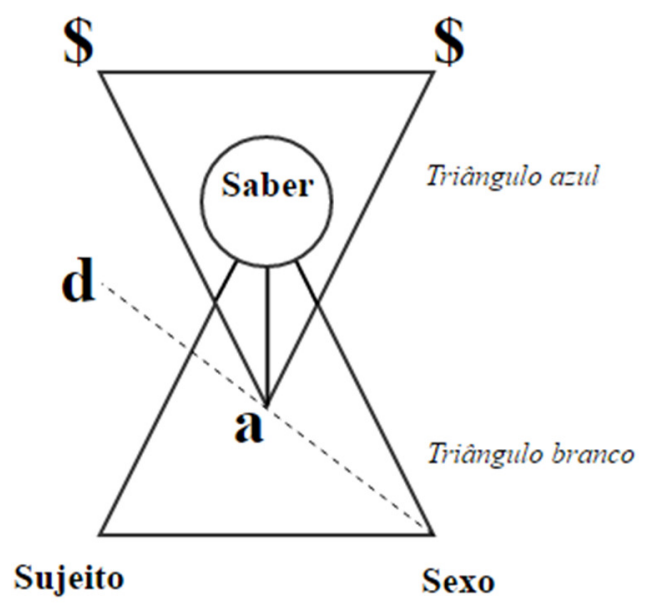

Figura 5: Representação da relação entre analista e analisante, articulada aos três elementos do jogo: Sujeito, do Saber e do Sexo (Lacan 1964-65/2006, pg. 356)

Neste ponto podemos notar também como a discussão proposta por Lacan se aproxima daquilo que teria sido sua primeira proposta de tema para o Seminário daquele ano: a questão das posições subjetivas. Isso porque os dois temas se mostram intrinsecamente relacionados: não se pode falar de uma organização ou formalização da prática psicanalítica sem levar em conta a questão do sujeito e as possíveis posições subjetivas do ser. Tais posições seriam justamente marcadas por esses três elementos destacados por Lacan: o sujeito, o saber e o sexo. Neste sentido, o próprio Lacan reconhece essa articulação:

"Lhes tinha anunciado que falaria neste ano das posições subjetivas do ser e depois, por um movimento de prudência, eu me contentei 
em falar de problemas cruciais para a psicanálise. Não que meu primeiro desenho tenha sido por isso abandonado. As posições subjetivas do ser estão no quadro há umas quatro aulas minhas, sob os três termos do "sujeito", do "saber" e do "sexo". É bem de posições subjetivas, do ser do sujeito, "je suis" de Descartes, do ser do saber e do ser sexuado, de que se trata na dialética psicanalítica, e nada é concebível sem a conjugação destes três termos." (Lacan, 1964-65/2006, pg. 359)

Colocados então estes três termos e estabelecidos os principais pontos dessa analogia entre psicanálise e um jogo, vejamos então qual seria a montagem e objetivo desse jogo, a partir do exposto por Lacan em sua lição de 19 de maio de 1965.

Temos então os três elementos de nosso jogo, os três termos do sujeito, do saber e do sexo. Sobre sua articulação em um jogo, Lacan nos afirma:

"Essas observações são essenciais para introduzir o que desejo articular para vocês hoje, a saber, o que é o jogo da análise - se é que, como ela tem todos os caracteres disso, a análise é um jogo porque ela prossegue no interior de uma regra - e que se trata de saber como o analista tem que conduzir esse jogo, para saber também quais são as propriedades exigíveis a sua posição para que ele conduza essa operação de uma maneira correta." (Lacan, 196465/2006, pg. 355).

Vemos aqui retomada a ideia de que a formalização da prática clínica, neste caso tomada à semelhança de um jogo, permitiria estabelecer os critérios mínimos para condução do tratamento de "uma maneira correta". Ora, se há um maneira correta, forçoso admitir que haveria também uma maneira não-correta, sendo esta formalização vital para permitir algum modo de evitar ou reduzir casos de condução incorreta do tratamento.

Nesta formalização, se por um lado temos os três pólos propostos por Lacan (sujeito, saber e sexo), por outro lado temos duas pessoas envolvidas, analista e paciente. Como pensar, então, os jogadores desse jogo? Seria necessária uma 
desarticulação ou separação entre os três polos propostos por Lacan, como se fossem jogadores independentes?

Lacan ataca essa problemática partindo inicialmente da ideia intuitiva de que poderíamos inicialmente pensar a análise como um jogo composto por dois jogadores, analista e paciente: "esse esquema, é que numa análise há, aparentemente, dois jogadores". (Lacan, 1964-65/2006, pg. 356). Ênfase dada aqui ao termo "aparentemente", vez que Lacan irá demonstrar que não é exatamente destes dois jogadores que se trata, ainda que o analista tenha também seu papel neste jogo.

Para isso, Lacan retoma então um dos pontos centrais desse Seminário: o analista em sua posição de sujeito suposto saber. Tem-se que a relação que se estabelece entre analista e paciente se articula como um mal-entendido, quando o paciente coloca o analista na posição de suposição de saber, de quem sabe sobre o seu sintoma e seu sofrimento. Se é na falha do saber que é possível emergir o sujeito, é ao situar o saber do lado do analista que o paciente participa do jogo em sua posição de sujeito. Sabemos, porém, que esse saber é apenas suposto e que quem o sabe, de fato, é o próprio paciente, ainda que se trate de um saber inconsciente. Neste sentido:

"Esses jogadores cuja relação tentei articular para vocês como uma relação de mal entendido, uma vez que, do lugar que ocupa um dos jogadores, o outro que é o sujeito, é o sujeito suposto saber, ao passo que, se vocês acreditam em minha articulação esquemática, o sujeito - se podemos falar desse polo em sua constituição pura - o sujeito só se isola ao se retirar de toda suspeição de saber. A relação de um desses polos com o polo do sujeito é uma relação de falácia, mas é também nisso que ela se aproxima do jogo; o sujeito tem, de início, que saber que no nível do saber ele não tem que supor sujeito, uma vez que é o inconsciente." (Lacan, 196465/2006, pg. 356)

Assim, a participação do analista nesta montagem do jogo psicanalítico é de estar nesta posição radical de sujeito ao qual é possível conferir uma suposição de saber, que garante a possibilidade de que o paciente se coloque como sujeito, dando início ao jogo. Assim, afirma Lacan: 
"se o analista, em sua posição pura, original, não tem outra posição senão aquela do sujeito tal como eu o defini cartesianamente, colocando aquele que em todo caso se afirma que, mesmo se ele não sabe de nada, ele é aquele que pensa que não sabe nada e que isso basta perfeitamente para garantir sua posição em face de outro jogador, que sabe, sem dúvida, mas não sabe que sabe.". (Lacan, 1964-65/2006, pg. 356)

Trata-se, então, da função do analista enquanto sujeito suposto saber que permite e engendra, na verdade, a própria articulação para o paciente entre sujeito e saber, dando início ao jogo a partir dos três elementos destacados: sujeito, saber e sexo.

Aqui, mais uma vez, Lacan faz recurso a teoria dos jogos de Von Neumann. Na teoria dos jogos, jogadores são os agentes do jogo, que fazem seus lances ou suas jogadas, respeitando uma certa ordem de preferência. Contudo, também na teoria dos jogos, Von Neumann demonstra que, no caso já mencionado do ponto de sela, é possível que dois ou mais jogadores, mesmo sem nenhum tipo de acordo ou aviso prévio entre si, venham a alcançar certa estabilidade e acordo em seus lances, talvez até mesmo realizando os dois o mesmo lance a cada rodada. Desse pressuposto da teoria dos jogos Lacan extrai a possibilidade de que esses dois jogadores, analista e paciente, possam também ser entendidos, em certa medida, como apenas uma pessoa, um único jogador, se considerarmos que os dois tem apenas um mesmo lance igual para jogar, ou nas palavras de Lacan:

"esses dois polos (do analista e do paciente) podem constituir valiosamente, até um certo ponto, uma mesma pessoa, se definimos a pessoa não por essa referência mas pelo interesse comum. E o interesse comum é o que se chama a cura.". (Lacan, 1964-65/2006, pg. 357)

Lacan retoma então, mais uma vez, a teoria dos jogos, com a proposta de Pascal acerca da teoria da partilha. Relembrando, trata-se da ideia de que no jogo deve haver um momento qualquer no qual é possível uma repartição ou redivisão das apostas envolvidas, de tal modo que resulte num arranjo mais satisfatório para os jogadores 
envolvidos. Não se trata de retirar as apostas, mas de rearranjá-las, conforme as posições de cada jogador no jogo. E é dessa noção de redistribuição das apostas entre os jogadores que Lacan aproxima a noção de cura no tratamento psicanalítico. E aqui - em resposta à questão acerca de quem seriam os jogadores desse jogo - não são tomados os dois jogadores (analista e paciente), mas sim os três polos: sujeito, saber e sexo. Ao se falar em cura, o que temos então nada mais é do que uma redistribuição das apostas, um acerto de contas entre estes polos. Ou, como afirma Lacan: "A cura não tem absolutamente outro sentido senão essa repartição das apostas num ponto qualquer do processo.” (Lacan, 1964-65/2006, pg. 357)

Essencial destacar aqui que não se trata de um reajuste ou equilíbrio apenas entre o sujeito e seu saber. Um manejo desse tipo, de um melhor acordo entre sujeito e saber, é o que poderíamos considerar como típico das psicoterapias diretivas, que visam o fortalecimento do ego do paciente e sua identificação com a pessoa do analista, destacadas no capítulo anterior a partir dos textos de Maleval. Lacan mesmo faz nesse ponto crítica a esse tipo de análise que toma base nessa relação saudável do sujeito com seu saber: "É o que todos os analistas da escola de La psychanalyse d'aujourd'hui chamam, nessa falsa linguagem tomada da psicologia, 'a aliança com a parte sã do eu', dito de outro modo, enganamo-nos juntos!”. (Lacan, 1964-65/2006, pg. 357).

O que confere à prática psicanalítica sua especificidade é justamente a incidência desse terceiro termo, o sexo e a realidade da diferença sexual, sendo essencialmente a inclusão deste terceiro elemento que confere à análise a possibilidade de um desfecho outro que não o da mera identificação do paciente ao ego forte do analista. Neste sentido, Lacan afirma: "Se há alguma coisa que tento reintroduzir, que permite ao analista chegar a outra coisa que a uma identificação do sujeito indeterminado com o sujeito suposto saber, isto é, com o sujeito do engano, é na medida em que lembro o que, mesmo aquele que têm essa teoria sabem na prática, é que há um terceiro jogador!” (Lacan, 1964-65/2006, pg. 357), sendo este jogador a realidade da diferença sexual.

O saber de que se trata é do saber do próprio sujeito, com o qual estabelece uma relação desde muito antes de sua entrada em análise, desde sua constituição como sujeito e a foraclusão do significante original ou, em outras palavras, a recusa em saber 
acerca da diferença sexual. Desde essa origem, o sujeito se articula ao seu saber, mas apenas enquanto aquilo que sobra como resto, como resíduo da operação de foraclusão deste saber do qual o sujeito nada quer saber. Tal arranjo só é possível por meio de uma solução, um arranjo ou amarração entre esses três termos, de uma forma singular para o sujeito, ou seja, seu fantasma, sua fantasia inconsciente. É justamente aí que reside a aposta desse jogo: na solução dada pelo sujeito para se arranjar com uma articulação entre o seu ser de sujeito, seu saber inconsciente e esse impossível de saber recusado, mas que incide ainda sob a forma desse objeto destacado por Lacan, o objeto $a$. É assim que articula Lacan:

"É por isso que, diante dessa realidade da diferença sexual, o sujeito que sabe, que não é o analista mas o analisado, é desde muito tempo constituído em seu próprio jogo, aquele que durou, começou e culminou até a análise, (...) necessária de dois sujeitos, do sujeito dividido, de um lado sujeito, de outro lado saber, mas não juntos. E de alguma coisa pela qual ele só pode se apreender como caído e dejetado da realidade da qual ele não quer nem pode saber nada; no que faz com que sempre o homem tenha que fugir do impossível da realidade sexual, nesse algo que é suplemento lúdico e também a defesa, esse algo que conhecemos, sob a forma do que se revela no fantasma enquanto a causa é aí a aposta em jogo do sujeito, sob a forma desse objeto da relação de objeto, aposta em jogo entre os dois termos subjetivos opostos do sujeito e do saber inconsciente." (Lacan, 1964-65/2006, pg. 357)

Assim, é na relação com esse terceiro elemento do jogo, o sexo, que se situa a especificidade da prática psicanalítica. Inclusive, é aí que Lacan localiza a própria regra que organiza e possibilita a instauração do jogo da psicanálise:

"Essa substituição do $a$, do objeto de dejeção, do objeto de queda, nisso que se trata, da realidade da relação sexual, está aí o que dá sua lei a essa relação do analista com o analisado, nesse sentido que, antes que tenha que se contentar com alguma repartição equitativa das apostas, ele tem a ver com alguma coisa onde ele se acha igualmente numa posição de oposição a seu parceiro." (Lacan, 1964-65/2006, pg. 358) 
Essa relação com a realidade da diferença sexual é o que institui a regra do jogo e estabelece também uma relação de oposição entre os dois jogadores do jogo. Não entre analista e analisado, mas entre o sujeito do analisado e o polo da realidade sexual. Se o sujeito busca a análise é por um certo desacordo ou desequilíbrio na relação entre os três polos desse jogo, não sendo capaz de alcançar o ponto de sela, como extraído da teoria dos jogos. Mas se não se alcança tal solução de acordo, é porque há em algum ponto uma oposição, uma disputa e um conflito que coloca um dos jogadores na defensiva. É claro que aqui podemos localizar esta posição defensiva em relação à resistência por parte do analisando. Mas o que cumpre destacar é que essa resistência, ao contrário do que por vezes se acredita, não se dá em relação ao analista, não se dirige a ele, mas sim ao outro polo da relação, ao polo da realidade sexual. Trata-se de um conflito sem solução, vez que, por mais que se esforce o sujeito para vencer o jogo, esse polo sexual não pode ser derrotado ou eliminado. E aqui se localiza justamente a participação vital do analista, enquanto aquele que conduz o tratamento: o esforço em colocar um fim ao impasse, em propiciar uma redistribuição das apostas que leve em conta os três polos desse jogo, tomando essa aposta a partir de uma referência a este objeto $a$ e, consequentemente, ao desejo do sujeito. Para Lacan:

"O que faz a força dessa defensiva é que ela é dirigida contra o outro polo, aquele da realidade sexual. Ela é imbatível justamente por isso, que não tendo solução, a astúcia do condutor do jogo, se o analista pode merecer esse nome, só pode ser por isso, por fazê-lo chegar ao fim, por desprender dessa defensiva uma forma sempre mais pura. E é isso que é o desejo do analista na operação." (Lacan, 1964-65/2006, pg. 358)

Temos então a referência ao desejo do analista, mas não no sentido de que o próprio desejo do analista que seja de algum modo transmitido ou conferido ao analisando, mas porque é a posição assumida pelo analista, em relação ao analisando, que lhe permite esse outro tipo de solução para a questão da oposição com a realidade da diferença sexual, por meio do reconhecimento de seu desejo. Ou, como afirma Lacan: 
"Levar o paciente a seu fantasma original, não é ensinar-lhe nada, é aprender com ele como fazer. $\mathrm{O}$ objeto $a$ e sua relação, num determinado caso, com a divisão do sujeito, é o paciente que sabe fazer com isso, e nós estamos no lugar na medida em que o favorecemos. A análise é o lugar onde se verifica de uma maneira radical porque ela mostra a estrita superposição disso: que o desejo é o desejo do Outro. Não porque ao paciente seja ditado o desejo do analista, mas porque o analista se faz o desejo do paciente. Isso é expressado pelo triangulo vermelho (Fig. IXI - 3), que mostra qual espaço virtual do lado do Outro, lugar ocupado pelo analista, se situa o ponto de desejo, isto é, no polo estritamente oposto ao lugar onde jaz o impossível da realidade do sexo." (Lacan, 196465/2006, pg. 358)

Sobre isso, Lacan propõe a seguinte representação:

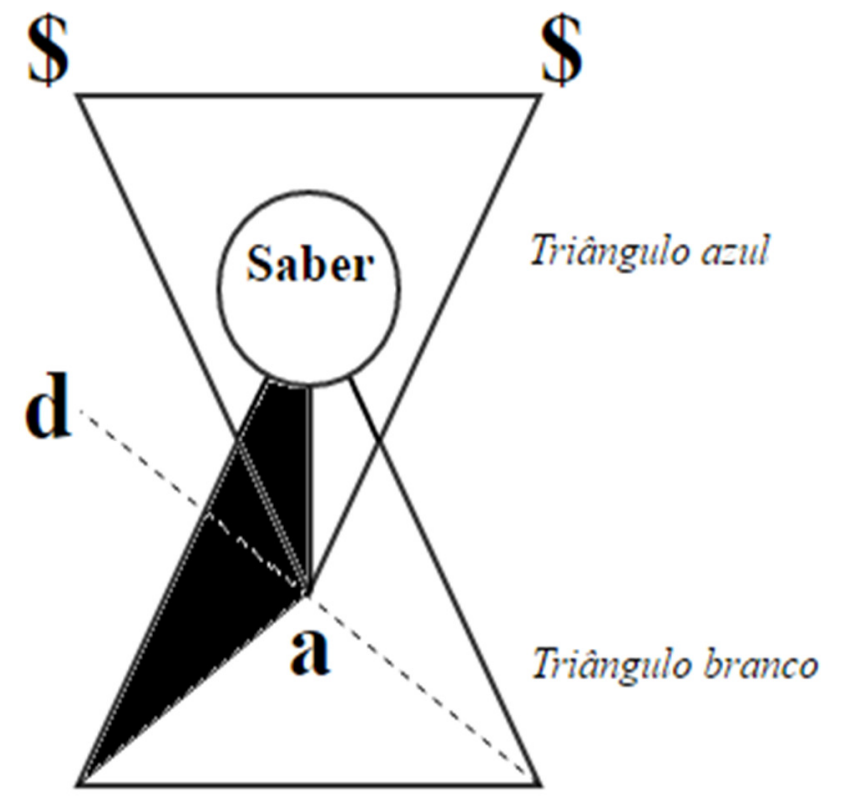

\section{Sujeito}

Sexo

Figura 6: Representação do Sujeito, do Saber e do Sexo, em relação ao objeto a e ao desejo (Lacan 196465/2006, pg. 352) 
O papel do analista no tratamento ganha então sua relevância a partir desse manejo por parte do analista como aquele que atua como cúmplice, na condução do jogo, mas que ao mesmo tempo se mantém alerta para conduzi-lo rumo a um fim, a um rearranjo dos riscos, aberto para a possibilidade de emergência de uma nova aposta. Nessa possibilidade do analista em sustentar este jogo, abrindo a fresta para a possibilidade de que se articule para o sujeito uma nova forma de relação com seu saber, e com esse limite colocado pela realidade sexual. É neste sentido que deve operar o desejo do analista:

"Ora, é aí que jaz o supremo da astucia analítica, e é apenas aí que ela pode ser alcançada. É apenas nessa perspectiva, e na medida em que o analista é totalmente flexível a ela, que pode passar alguma coisa do que constitui, para falar propriamente, o único ganho concebível. (...) Qual deve ser, qual pode ser esse desejo do analista, para se sustentar ao mesmo tempo nesse ponto de suprema cumplicidade, cumplicidade aberta, aberta a que? À surpresa. O oposto dessa espera onde se institui o jogo em si, o jogo como tal é o inesperado. O inesperado não é o risco. A gente se prepara para o inesperado. (...) Porque, o que é o inesperado senão o que se revela como sendo já esperado, mas apenas quando acontece? O inesperado, de fato, atravessa o campo do esperado. Em torno desse jogo da espera, e fazendo face à angústia, como o próprio Freud, nos textos fundamentais sobre o tema, o formulou, em torno desse campo da espera nós devemos descrever o estatuto do que é do desejo do analista." (Lacan, 1964-65/2006, pg. 359)

A exposição acima dá um panorama do modelo proposto por Lacan para a prática clínica, em sua lição de 19 maio de 1965. Tal esquema parte dos elementos fundamentais que compõem o jogo (sujeito, saber e sexo), apresenta a possibilidade de pensar a relação entre esses três elementos como aquela de uma dominância circular, articula a montagem do dispositivo analítico a partir da relação do sujeito com seu saber e, mais especificamente, a suposição de saber colocada no analista, para culminar nas possibilidades de desfecho para a análise, em que o analista, enquanto condutor do jogo e a partir de seu desejo de analista, permite ao analisado a emergência de um novo arranjo entre seus três polos, de um modo mais puro, que leve em conta o 
reconhecimento também de seu desejo, como solução para o impasse em relação ao impossível da realidade sexual.

Mas se isso nos apresenta o quadro geral para o funcionamento da clínica psicanalítica, cumpre daí extrair agora quais seriam as implicações para o curso desse jogo, para o meio da partida, as jogadas possíveis ao analista na condução desse jogo. Para isso, vamos nos remeter às articulações feitas por Dunker (2015) em seu Seminário sobre a obra de Lacan, em aula de 03 de junho de 2015.

\section{O LanCe-A-Lance do Jogo Psicanalítico}

Seguiremos então os desenvolvimentos de Dunker (2015). Vamos, inicialmente, retomar a proposta de construção desse jogo. Temos três polos envolvidos (sujeito, saber e sexo), esses polos se articulam numa relação de dominância circular. O sujeito, aqui, primeiro jogador, é o sujeito inaugurado pela foraclusão de um significante primordial, resultando na divisão do sujeito, o que o institui, também, como essencialmente marcado pela falta. Esta falta se articula ao segundo elemento deste jogo, o saber, na medida em que o sujeito articula sua falta a este saber. É a esse saber que o sujeito recorre mas para nele se abolir de sua posição de sujeito, se demitir, alienar, na articulação com esse saber que compõe seu suplemento lúdico, seu fantasma. Trata-se também de um saber cujo sujeito é indeterminado. Por fim, o terceiro elemento, que promove o furo no saber, enquanto representante daquilo que é impossível de saber, inacessível à linguagem: o sexo. Por fim, é sustentado na certeza desse impossível de saber que o sujeito se articula.

Contudo, se no jogo de jo-ken-po sabemos quais são os três elementos e o modo se afetam mutuamente (a pedra amassa, o papel embrulha, a tesoura corta), cumpre avançar na analogia para aprofundar e detalhar melhor de que modo os três elementos apresentados por Lacan como jogadores desse jogo analítico poderiam se relacionar uns com os outros. Quais seriam as variações e definições que constituem esse jogo? 
Se temos que, quanto ao saber, o sujeito desse saber é indeterminado, emerge então para o sujeito a questão acerca da constituição ou fonte desse saber ou, colocando de outro modo, a condição para esta possibilidade de acesso a este saber está relacionada à busca por uma resposta para a pergunta: "quem sabe?". Tem-se aí um primeiro momento da relação do sujeito com seu saber.

Ou seja, partindo apenas destes dois elementos iniciais - o sujeito e o saber - já tem início a montagem do jogo psicanalítico. Essa montagem se inicia com um primeiro modo de jogar, ou melhor, uma primeira possibilidade de lance, que se estabelece do sujeito em direção ao saber. Trata-se do momento em que o sujeito procura um analista, e começa a falar a esse analista, dizendo de si e permitindo que o analista, com sua escuta, tenha algum acesso à posição que o sujeito, enquanto faltante, ocupa no discurso. Assim, por um lado, o sujeito fala e do outro o analista escuta, espera, oferece ao sujeito a possibilidade de continuar sua fala. Nessa fala do sujeito e espera do analista há a produção de um saber, saber sobre o próprio sujeito, sobre sua vida, suas relações pessoais, seu sofrimento, enfim, temas de interesse desse sujeito mas que ele os localiza no lugar do analista. Deposita esse saber no analista, em busca de uma resposta sobre si.
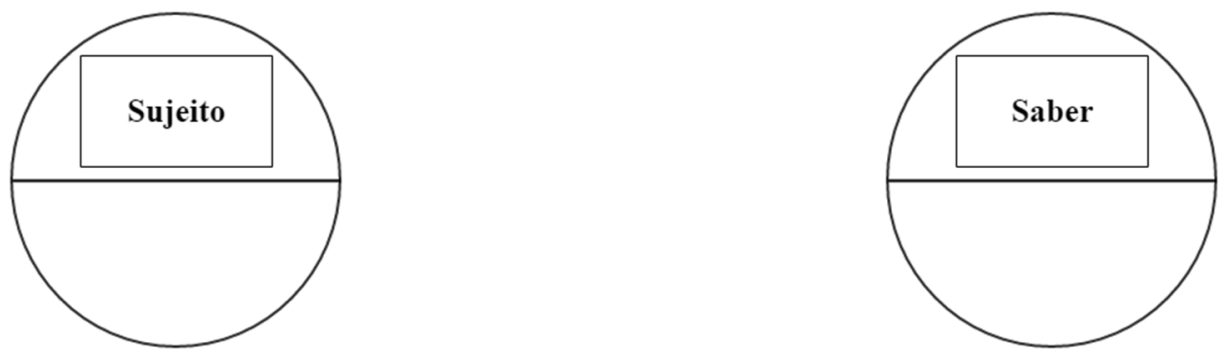

Figura 7: Representação do paciente e do analista no início do tratamento

A partir dessa fala do paciente e, consequentemente, dessa possibilidade de construção de um saber, emerge então a questão: “Quem sabe?". É a pergunta que sustenta o saber. Quem é aquele que pode responder por este saber que falta ao sujeito. Ao falar ao analista, o sujeito supõe a ele esse saber. Ou seja, uma fala do sujeito para o 
analista, que produz um saber, cujo sujeito ainda não se sabe e que leva a endereçar ao analista a pergunta: “quem sabe?”, na espera de que o analista saiba responder.

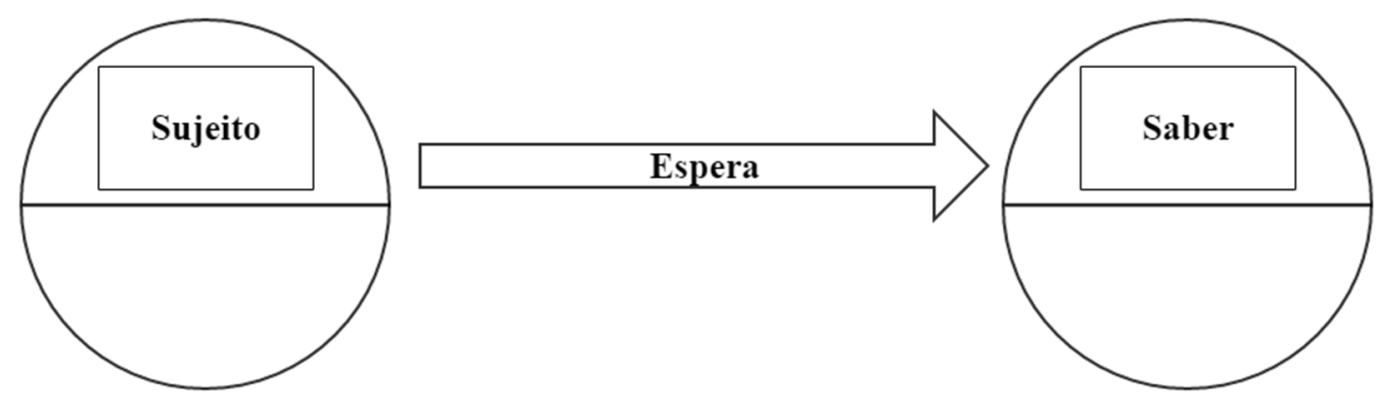

Figura 8: Representação do Sujeito endereçando sua fala ao analista

Diante deste impasse, se configura um segundo modo de relação entre sujeito e saber que é a relação de saber suposto. O paciente supõe ao analista um saber e o analista sustenta, inicialmente, tal posição, ainda que com ela não se identifique. Assume um semblant, suposição do saber.

Inicialmente, então o analista mantém sua posição de espera, de escuta analítica, dando possibilidade de constituição desse saber, saber então suposto ao próprio analista. Dessa relação de suposição de saber estabelecida entre analisando e analista podemos extrair a própria forma de montagem ou constituição do que configura a transferência no curso do tratamento analítico, como Lacan indica diversas vezes ao longo deste Seminário.

A transferência se articula a partir desta ordem de coisas: um sujeito, que fala a um analista que, em contrapartida, escuta o paciente e espera, permite ao sujeito a construção de algum saber e de uma questão acerca de quem sabe, e isso retorna para o sujeito na forma de uma suposição de saber à pessoa do analista. Nessa fala do analisando, ele supõe o analista no lugar de um outro, de um sujeito e, ao dirigir sua fala a ele, esse outro passa a ganhar sua importância e ser parte deste processo de fala e começam a se articular o saber e o sujeito, com a questão sobre quem sabe. Tal questão 
começa a ser respondida, de início com essa suposição de saber, a crença para o sujeito de que quem sabe é o outro, este analista, que o escuta e ao qual o saber é suposto. Temos, então, essa representação da montagem da transferência:

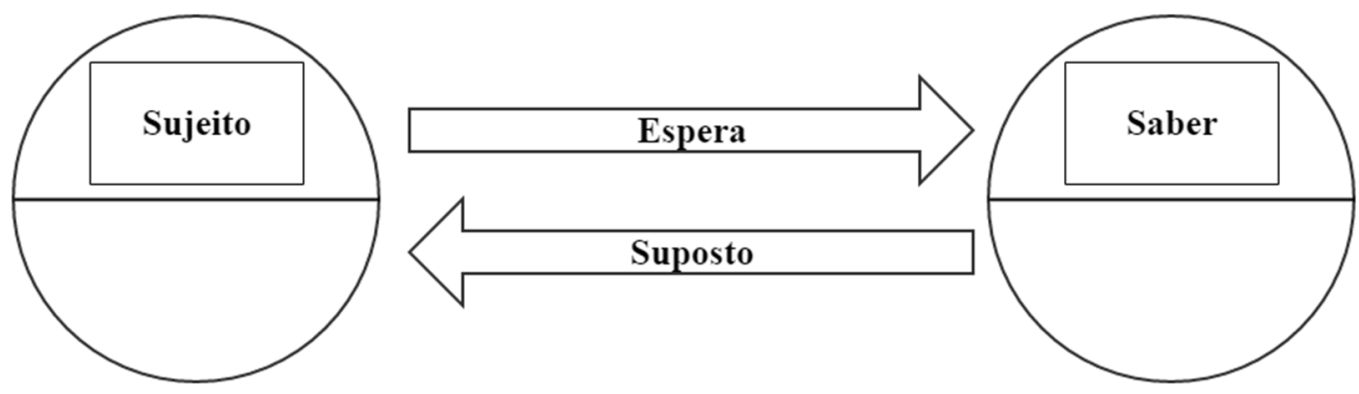

Figura 9: Representação da suposição de saber no analista e montagem da transferência

Temos então um terceiro momento, que parte desta dinâmica estabelecida entre sujeito e saber, entre o paciente que fala e o analista em sua posição de espera e suposto saber. Essa dinâmica entre espera e suposição pode ir se modificando e flutuando ao longo do tratamento: quanto mais espera, mais suposição de saber e o contrário também se aplica. Variação que é efeito também do decurso do tempo e dos diversos momentos vividos em um tratamento psicanalítico.

Porém, não se pode esperar que o jogo fique restrito apenas a isso. Esse movimento de acúmulo crescente de suposição de saber precisa ser modificado em algum momento. Para isso temos o que Lacan coloca como a possibilidade de que intervenha um significante qualquer do psicanalista. Algo de inesperado e capaz de atravessar esses eixos da espera e da suposição, dando abertura a uma nova dimensão do tratamento, caso essa intervenção do significante qualquer do analista opere adequadamente. Mas caso isso não ocorra, teremos um desenvolvimento menos favorável.

Desse modo, temos dois caminhos possíveis a partir dessa situação inicial de espera e suposição de saber. O primeiro resultado possível é o de emergência da angústia. E aqui temos um ponto que será de grande valor e que nos interessa para o tema das possíveis iatrogenias no tratamento psicanalítico. Algo que se repete com 
alguma frequência nos consultórios: o paciente busca o analista e passa a falar para esse analista, durante sucessivos encontros e o analista não responde. Silencia. Apenas sustenta sua escuta, sem sua espera, sem nenhuma intervenção. Como nas queixas que ouvimos com alguma frequência: "meu analista nunca fala nada". E acumula mais e mais saber suposto, aumenta mais a transferência. Mas isso ao mesmo tempo aumenta mais e mais a angústia no sujeito. Caso tal cenário se mantenha e continue a se repetir por muito tempo, sem uma resposta por parte do analista, pode se configurar uma intensificação tão grande da angústia que resulte em consequências iatrogênicas, como casos de acting outs por parte do paciente, ou mesmo a queda em angústia e sofrimentos profundos que poderiam ser considerados efeitos iatrogênicos do tratamento. Esse ponto será retomado futuramente.

A segunda possibilidade de desfecho para essa situação, a partir da intervenção de algo inesperado por parte do analista, seria um outro lado do inesperado, algo a ver com o destino do inesperado, algo que atravessa a sessão, e que se apresenta para o analista: o que fará com isso que lhe é dito pelo paciente? Intervém aí, então, algo que se aproxima do que é definido por Lacan como desejo do analista, que se apresenta neste momento: como responder a partir de seu lugar de escuta, diante de um saber que lhe é suposto? No que o analista irá se amparar, de onde irá responder. É essa resposta inesperada para o sujeito, por parte do analista, mobilizado por seu desejo de analista, que poderá dar continuidade ao processo analítico. Diante dessas duas possibilidades, temos a seguinte formulação:

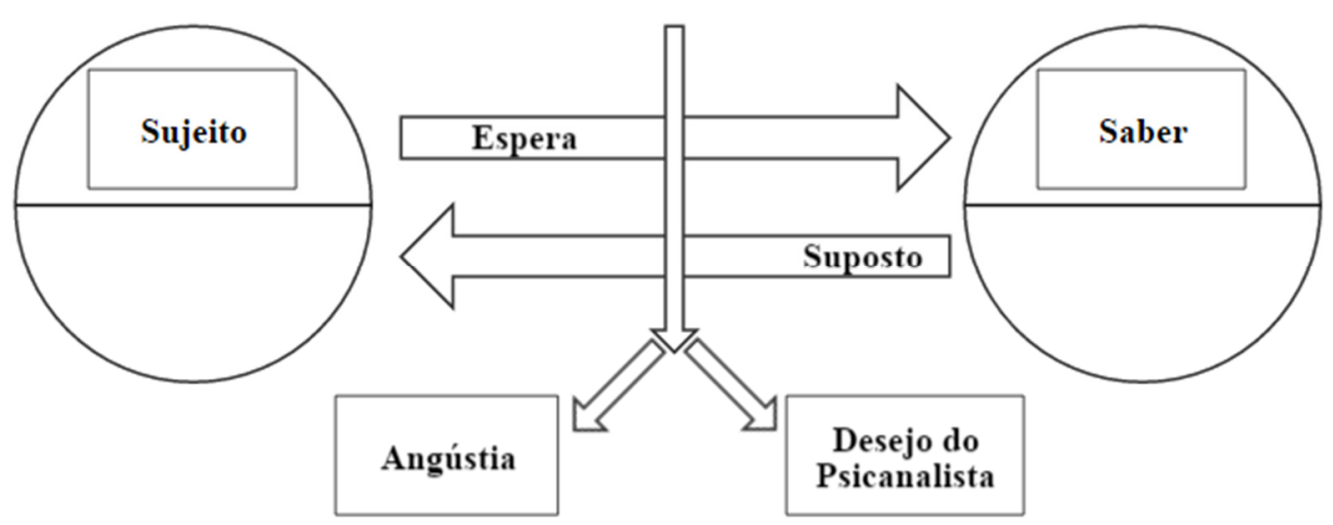

Figura 10: Surgimento de angústia ou incidência do desejo do analista, a partir da relação transferencial 
O jogo poderia proceder desse modo cíclico: fala do sujeito, articulação de um saber, espera do analista, questão sobre quem sabe, suposição de saber, intervenção do analista e do desejo do analista, e assim sucessivamente. Mas é justamente esse tipo de concepção que Lacan visa combater, ao propor que o jogo analítico se articula não em torno de dois, mas sim de três termos. Há posteriormente um certo momento no qual deve incidir o terceiro polo ou o terceiro jogador deste jogo que seria o sexo, a realidade da diferença sexual, a verdade da impossibilidade sexual para o sujeito. $\mathrm{O}$ aspecto da diferença sexual para o sujeito como um elemento que também participa desse jogo, sendo capaz de dar cartas e ditar seu rumo.

Temos então o modo como o sexo, ou mais especificamente, a verdade sobre o sexo, promove um furo no saber, um impossível de saber, interditando a possibilidade de um saber que possa se fazer inteiro, uno e universal. Entre os polos do jogo, saber e sexo, o que se encontra é uma relação que não se dá, que se depara com um furo, uma impossibilidade, operação diante da qual emerge um efeito de resto, situado como nosso terceiro jogador, o sujeito. Sujeito que aparece então como resto dessa operação, dessa falta que o sexo promove no saber. Para Dunker (2015):

"Ou temos uma disjunção entre saber e sexo, ou seja, entre o saber e a verdade sexual, ou, então, temos uma conclusão entre estes elementos mas que têm como resultado o sujeito apenas como resíduo, como objeto, excluído dessa operação."

Assim, é situado entre saber e sexo o regime da regra, da lei, da tentativa de controle sobre o impossível da relação sexual. Um saber que não pode alcançar o impossível da relação sexual, e cuja tentativa de enquadre se dá pelos modos de alienação do sujeito: seu fantasma, sua fantasia, sua relação com a Lei, sua relação com a interdição do incesto.

Pode-se localizar aí, também, por exemplo, a regra da abstinência, na proibição da relação sexual entre analista e seus pacientes, um aspecto que nos interessa também, com relação ao tema da iatrogenia. Interdita-se a relação entre o saber, de um lado, e verdade do sexo do outro. 
Já na relação do sujeito dividido com sua verdade sexual - primeiro e terceiro jogador - temos num sentido uma aposta e, em sentido oposto, a falta. O impossível da relação sexual aponta para o sujeito a irredutibilidade de sua falta. $\mathrm{O}$ que volta do sexo para o sujeito é a falta, onde o impossível, o real do sexual, retorna para o sujeito dizendo que é, enfim, castrado, o impossível de saber dessa castração, impossível de ser dominada. Mas, deparando-se com a questão de sua verdade sexual, o sujeito responde, devolve e deve se posicionar a partir de uma aposta, aposta enquanto possibilidade de resposta diante do impossível de saber. Sujeito pode apostar no seu fantasma, na sua fantasia, na consistência sexual, na relação com o outro, na natureza dessa verdade, etc..

Segundo Dunker (2015): “tal formalização seja talvez a mais prática, simples e sensível, dentre os modelos formulados por Lacan, com uma grande capacidade de ser incorporada intuitivamente à prática clínica”. Ou seja, quando escutamos o paciente em uma análise, tem-se a dinâmica de um jogo, jogado numa sucessão de lances. Em alguns momentos o analista espera a fala do paciente, deixa que ele faça sua jogada primeiro, para então responder com a sua. Em outros momentos, o analista faz uma intervenção, uma jogada, a qual o paciente irá responder, escolhendo dentre as três possibilidades disponíveis (pedra, papel ou tesoura / sujeito, saber ou verdade), configurando uma espécie de escuta negativa, uma dinâmica de negações, no sentido de que, se o sujeito coloca um elemento, o analista deveria colocar outro, diverso, que negue o colocado pelo paciente. Se o paciente coloca um segundo, o analista apresenta um terceiro. E assim as jogadas vão se alternando e a análise avançando. 


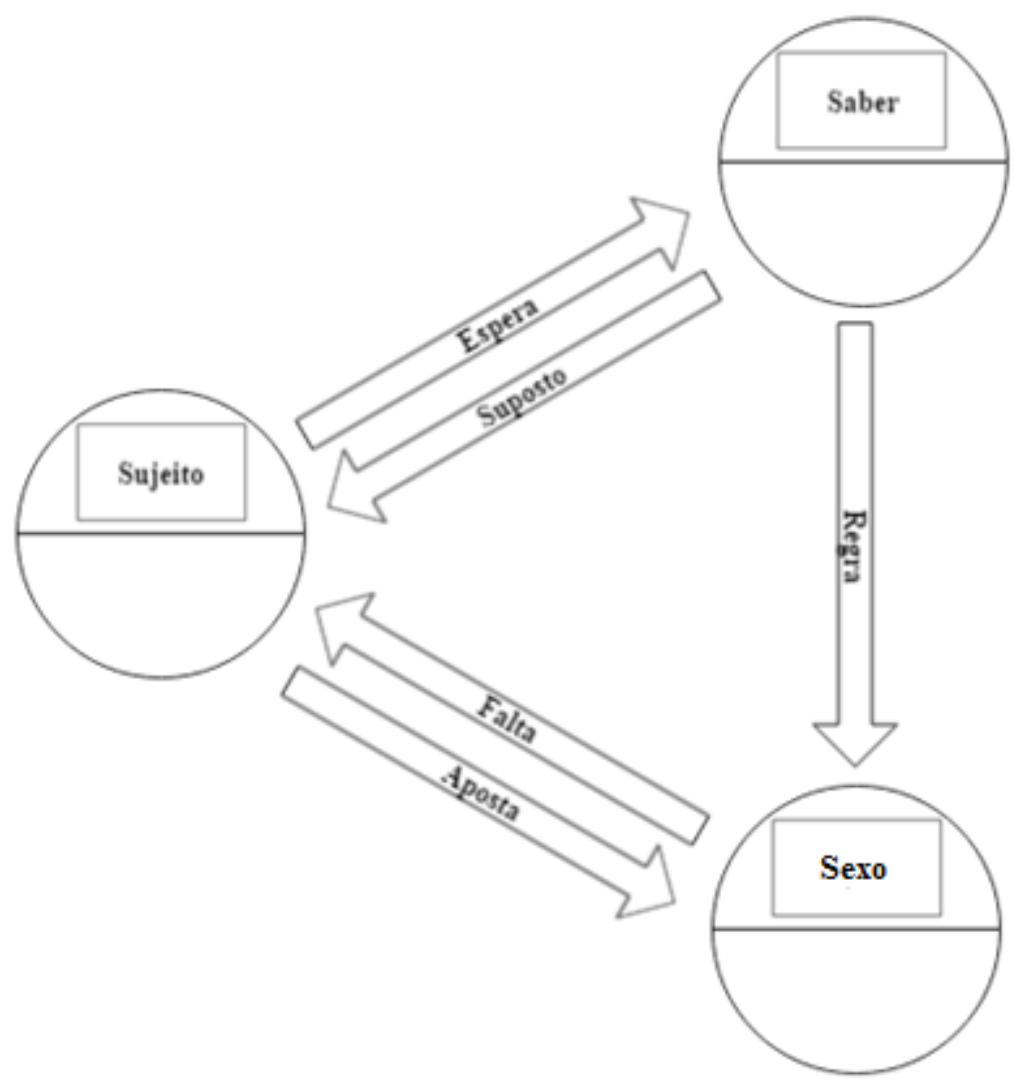

Figura 11: Representação completa do jogo psicanalítico no curso do tratamento

Esta última imagem demonstra a versão mais acabada do que seria a proposta de formalização do curso de uma análise a partir da ideia de um jogo, semelhante ao joken-po. Três elementos que podem ser jogados: Sujeito, saber e sexo. O analista pode "jogar" como sujeito, depois com o saber, retornar ao sujeito, ir para o sexo... Alternamse os lances, tanto por parte do analista, quanto por parte do paciente. A capacidade clínica do analista, a importância para saber jogar este jogo, é que sua escuta clínica lhe permita saber de onde está aquele falando o paciente, de qual das três posições, podendo responder em uma dialética diferente, com um lance diferente, fazendo, assim, uma passagem de um desses polos para um outro polo, sendo esse o mecanismo para que a análise avance ou não.

Um modelo de grande simplicidade e eficácia, que responde a muitas situações que se apresentam no dia-a-dia da clínica. Nesse modelo podemos localizar e 
compreender melhor muitas das queixas mais comuns de pacientes sobre suas análises. Podemos, inclusive, considerar que diversas práticas clínicas ou orientações psicanalíticas, atuam com enfoques mais específicos em apenas um ou dois desses polos, resultando em prejuízos para o tratamento. Podemos pensar, por exemplo, nos casos de tratamentos que se estendem durante anos, com muitas intervenções e construções e saberes para o sujeito mas que, mesmo assim, de algum modo, despertam no sujeito certo mal-estar, sensação de que nada está mudando, que o trabalho está patinando, sem sair do lugar. Neste caso podemos estar diante de uma dinâmica de tratamento que privilegia excessivamente a relação do sujeito com o saber, excluindo a dimensão do sexo e do furo no saber.

Ou então, do lado oposto, quando o trabalho analítico fica paralisado em torno de uma determinada relação com a verdade sexual, que não pode ser articulada a um saber, nem flexibilizada ou relativizada, não permitindo que o sujeito possa promover algo de produtivo com esse algo da verdade sexual que se apresenta a ele. Temos nesse caso um trabalho excessivamente focado na dimensão desse terceiro polo, do sexo, mas que não está sendo capaz de articulá-lo a algum dos outros polos desse nosso jogo.

Poderíamos trazer outros exemplos clínicos, mas não se trata aqui de esgotar as possibilidades. De modo geral, nos interessa aqui, é a ideia desse modelo para a prática clínica, que se estabelece numa analogia a um jogo. Um jogo, com três elementos, que se alternam nos diversos lances entre analista e paciente. $\mathrm{O}$ operador desse jogo seria onde o analista vai colocar o "pacote mais pesado", o peso da escuta, para onde vai focar, aonde vai apostar, aonde vai convocar o sujeito. E a partir das relações entre esses polos podemos pensar as diversas operações envolvidas no tratamento psicanalítico, bem como suas implicações tanto em termos de produção de efeitos, quanto no que se relaciona ao potencial iatrogênico do tratamento, como veremos abaixo. 


\section{LoCALIZANDO AS IATROgenias no Jogo PSICANALítico}

Temos então uma primeira apresentação desse modelo de formalização como proposto por Lacan e desenvolvido por Dunker (2015). Como visto, se trata de um modelo bem condensado e simplificado da prática psicanalítica, que não visa apresentar todo o passo a passo de um tratamento, mas sim trazer os principais elementos envolvidos, para que a partir daí possam ser extraídas as consequências que possam balizar o dia a dia da prática clínica. Assim sendo, podemos tomar esse modelo para retornar à questão dos possíveis riscos iatrogênicos do tratamento.

A proposta então é de tentar localizar nesse modelo quais seriam os pontos mais sensíveis de possível ocorrência de efeitos iatrogênicos, ou seja, quais aspectos do tratamento representam maior potencial iatrogênico. Para essa discussão, vamos retomar o que foi apresentado nos capítulos anteriores sobre o tema da iatrogenia.

Como visto, a iatrogenia está relacionada aos efeitos causados pelo tratamento, havendo uma relação entre os efeitos de cura e os efeitos iatrogênicos: todo tratamento que tem o potencial para cura carrega em si também o potencial de causar prejuízos ao paciente. Tal constatação torna essencial que os profissionais de saúde estejam atentos aos potenciais riscos envolvidos em sua prática.

Apesar disso, como visto, o estudo sobre o tema da iatrogenia ainda enfrenta muitas dificuldades e obstáculos, desde a resistência dos profissionais em abordar o tema, até dificuldades na própria pesquisa e na possibilidade de identificar e localizar o potencial iatrogênico de cada prática. Diante desses obstáculos, a pesquisa sobre o tema tem avançado pouco, especialmente na área da saúde mental. Sem avanços na pesquisa sobre o tema, fica reduzida a possibilidade de mudanças que possam reduzir o potencial iatrogênico das práticas de cura.

Da pesquisa já existente sobre o tema, pudemos extrair alguns elementos que podem orientar a discussão sobre esse tema. Em especial o destaque dado à importância de estabelecimento de uma terminologia que permita distinguir e classificar as diversas modalidades de iatrogenias que podem ocorrer no tratamento. A partir da literatura, 
pudemos extrair uma primeira terminologia capaz de orientar essa diferenciação e classificação das iatrogenias.

Vimos então que as iatrogenias podem ocorrer como decorrência do modo de atuação do profissional ou então como decorrência de um risco inerente à própria técnica aplicada, independentemente de quem conduza o tratamento. Dentre as iatrogenias decorrentes da ação do profissional, distinguimos os casos de atuação dolosa, em que o profissional deliberadamente age com intenção de prejudicar o paciente e, por outro lado, os casos de atuação culposa do profissional, ou seja, casos em que não houve intenção por parte do profissional mas que, por algum erro na condução de seu trabalho, acaba causando prejuízos ao paciente. Nesta pesquisa a proposta foi de uma investigação mais aprofundada nessa área, a dos efeitos iatrogênicos causados por atuação culposa do profissional.

Dentre os possíveis casos de erro por parte do profissional pudemos ainda extrair da literatura três categorias principais: os erros por imperícia, os erros por negligência e os erros por imprudência. Tais conceitos serão utilizados na discussão apresentada neste capítulo, de modo que cumpre retomar também em que consiste cada um dos três.

Por imperícia temos os casos em que o efeito iatrogênico está relacionado a algum vício ou erro na aplicação da técnica, uma falta de domínio das técnicas, por falta de capacidade ou habilidade, falta de experiência ou competência específica para realizar um determinado procedimento ou intervenção, podendo ser resultado de ignorância, inexperiência ou inabilidade sobre a arte ou profissão que pratica. É o exemplo do cirurgião que se equivoca ao executar um procedimento cirúrgico, ou um dentista que realiza um procedimento de modo inadequado. Assim, se trata do reconhecimento acerca da existência de um certo padrão de conduta ou um modo esperado de atuação, reconhecido e aceito pelos profissionais da área e que, em determinado caso, acaba sendo mal executado.

Já a imprudência está relacionada à cautela necessária para condução de um tratamento, ou seja, a importância de não tomar ações precipitadas sem ter ainda maior clareza acerca da condição do paciente e de suas necessidades, não agir de modo 
apressado ou assumir riscos desnecessários, atuando sem a devida precaução ou cautela, de forma descuidada, sem atenção aos padrões que deveriam orientar sua conduta. É o caso, por exemplo, do procedimento cirúrgico ou uso de medicação realizados antes que sejam realizados diagnóstico ou exames adequados para confirmar a necessidade daquele procedimento. Ou mesmo casos em que se adota um procedimento que, ainda que seja adequado, se mostra excessivamente perigoso para o paciente quando haveria uma alternativa mais segura e de eficácia semelhante.

Por fim, a negligência refere-se às hipóteses de omissão ou descaso por parte do profissional, falta do devido cuidado, atenção, diligência ou aplicação por parte do profissional em um determinado procedimento, deixando que seus interesses pessoais se sobreponham aos do paciente.

Isto posto, partimos então para tentar localizar essas possibilidades de risco iatrogênico (imperícia, negligência e imprudência) no modelo proposto por Lacan e debatido por Dunker para formalização da prática psicanalítica a partir dos três elementos: sujeito, saber e sexo.

Seguindo o modo como o modelo foi apresentado, vimos que no início temos a relação entre o sujeito e o saber, a partir do momento em que o paciente passa a falar ao analista, enquanto o analista o escuta e espera. Nesse processo, temos como resultado uma suposição de saber que, a partir da questão “quem sabe?" é situado do lado do analista: o paciente supõe que o analista é quem sabe. Como vimos com Lacan, esse processo de suposição de saber representa o próprio estabelecimento da relação transferencial, o estabelecimento da transferência.

Desde Freud, a transferência já está situada como um dos fundamentos do tratamento psicanalítico. Assim sendo, se na transferência podemos localizar uma íntima relação com os fundamentos da técnica psicanalítica, então é possível articular que esse seria também um ponto de incidência do risco de iatrogenia por imperícia, ou seja, casos em que um uso incorreto dessa técnica, com manejo inadequado da transferência, podem representar um maior risco de iatrogenia para o paciente. 
A própria apresentação feita por Dunker (2015) sobre este momento de montagem da transferência já nos indica uma primeira possibilidade de risco iatrogênico. Ao mencionar que, uma vez estabelecida essa relação transferencial e suposição de saber por parte do paciente, há a possibilidade de emergência da angústia. Numa situação ideal, como também exposto por Dunker, espera-se que nesse momento intervenha algo de inesperado por parte do analista, um significante qualquer do analista (Lacan, 1967/2003), manifestação do desejo do analista e que poderia dar uma resolução para este impasse, abrindo a possibilidade de continuidade da análise. Porém, caso isso não opere, o risco é de que a situação de angústia perdure e se intensifique: cada vez mais suposição de saber, cada vez mais transferência mas também cada vez mais angústia do lado do paciente.

Tal cenário representa um risco iatrogênico significativo para o paciente, que pode recair em momentos de grande angústia ou sofrimento e até mesmo, em casos mais intensos, reagir em ato com acting outs, com consequências prejudiciais para o paciente e para o tratamento. Numa situação extrema, isso pode até mesmo levar à interrupção do tratamento, configurando grave efeito iatrogênico.

Podemos aqui pensar também em outras possibilidades, por exemplo, a partir da posição assumida pelo analista na relação transferencial e as identificações estabelecidas entre paciente e analista. Vimos no capítulo anterior como a questão da identificação do paciente à pessoa do analista pode representar um obstáculo à cura, ao obturar a falta do sujeito que se identifica ao ego forte do analista. Assim, a posição assumida pelo analista no tratamento e o modo como maneja a relação transferencial teriam importância vital para reduzir os riscos de que essa relação se configure de um modo contrário à cura, com resultados iatrogênicos para o paciente, que configurariam um erro por imperícia, por parte do profissional.

Como segundo passo do esquema de formalização apresentado estava a relação entre saber e verdade. Vimos como Lacan dá destaque à incidência do sexo nessa dinâmica, sendo a intervenção deste terceiro elemento que promove o furo no saber e estabelece a própria possibilidade e especificidade da prática psicanalítica. Lacan indica também que é nesse ponto que se institui a incidência da regra deste jogo analítico, 
colocando os limites do que pode operar na relação analítica. Dessa afirmação podemos facilmente extrair também a relação do sexo com a castração e a falta, enquanto esse limite colocado ao sujeito, mas que se articula também a uma regra, a regra da proibição do incesto.

Em sua discussão no modelo, Dunker (2015) indica que a essa ideia de regra podemos localizar, por exemplo, a proibição da relação sexual entre analista e paciente. Ou seja, certos limites na relação entre analista e paciente que, dentre outras coisas visam a resguardar a relação, do risco de que interesses pessoais do analista (como a atração sexual por uma paciente) possam atrapalhar o tratamento. O que está em jogo, então, é a capacidade do analista em deixar de lado seus interesses pessoais, seus aspectos narcísicos, em prol da condução adequada do tratamento. Sem dúvida uma violação dessa regra representaria uma iatrogenia no curso do tratamento, porém, no caso da relação sexual com paciente, poderia ser mais bem localizada no campo de uma ação dolosa por parte do terapeuta e não um erro por negligência. Porém, podemos situar neste ponto, da relação entre saber e sexo, e da regra estabelecida, outras questões que nos aproximem das iatrogenias culposas.

Vimos que a incidência do terceiro polo, o polo sexual é justamente o que promove um furo no saber e permite que o tratamento possa se desenvolver para além da mera relação entre sujeito e saber e, principalmente, para além da mera identificação do paciente à pessoa do analista. É a intervenção deste terceiro polo que promove um furo no saber e, consequentemente, uma abertura para o campo do desejo do sujeito. Lembrando aqui também a questão da regra do jogo, Lacan demonstra que essa regra do jogo está articulada ao conceito de objeto $a$, em sua relação com o desejo. Contudo, como visto anteriormente, para que isso possa se desenrolar de maneira adequada no curso do tratamento, é vital que haja uma intervenção por parte do analista, enquanto aquele que conduz o jogo. Nisso Lacan é enfático, ao situar também que tal posição do analista se relaciona ao que chama de desejo do analista. Isso é que se esperaria, em uma situação ideal de curso do tratamento psicanalítico. Mas o que podemos vislumbrar como possível risco nesse processo? 
No próprio Seminário 12, Lacan (1964-65/2006) nos confere uma importante indicação sobre este ponto. Em sua aula de 3 de fevereiro, Lacan discute um trabalho apresentado por uma analista inglesa, Pearl, trabalho feito com um paciente por ela definido como borderline. Lacan discute o modo como, mesmo após 10 de tratamento, algo não se resolvia para esse paciente. A própria autora cita em seu artigo um incomodo, tentando descrevê-lo sem muito sucesso até que, como último recurso acaba realizando "uma espécie de supervisão do caso, colocando-se face a face com o paciente" (Lacan, 1964-65/2006, pg. 151). Lacan toma esse caso para discussão e nos apresenta o impasse vivido pela analista, mas não percebido por ela, em que, mesmo após uma década de tratamento, não consegue promover um encaminhamento para o caso, falhando em "demarcar para o sujeito a função de seu desejo" (Lacan, 196465/2006, pg. 155), sendo incapaz de promover uma mudança, um giro no sujeito capaz de indicar algo da ordem desse impossível da relação sexual e convocando o sujeito a se haver com isso. Como afirma Lacan, Pearl não percebia o modo como era colocada em posição de objeto $a$ para o paciente e que, neste processo, tinha um gozo narcísico seu, ao ser objeto de desejo do paciente, sendo isso, em última instância que impedia o avanço no tratamento ao longo de todos estes anos.

Tal questão se aproxima também do que foi discutido a partir dos textos de Maleval, com a crítica - já mencionada - aos casos em que o analista se coloca como ponto de identificação para o paciente. Nestes casos, pode-se pensar num ganho narcísico, num gozo do analista ao ser tomado como modelo ideal ou mesmo como objeto de desejo pelo paciente. O que temos nesse caso é uma situação em que o analista coloca sua própria satisfação pessoal e seus próprios interesses acima dos interesses do paciente e da direção do tratamento no sentido da cura. Ora, a regra de interdição da relação sexual com pacientes não é de modo algum garantia de que dessa relação entre analista e paciente não esteja ocorrendo um jogo de sedução, de identificações, de idealizações, no qual possa incidir um gozo do analista que venha a representar um obstáculo ao tratamento.

Um cenário como esse configura uma situação em que o profissional demonstra descaso com os interesses do paciente, tomando decisões e conduzindo o tratamento 
mobilizado por suas próprias questões e ganhos pessoais. Isso pode ocorrer até mesmo de modo inadvertido ou sem que o analista perceba esse processo, tal como vimos com o caso de Pearl. Neste sentido podemos aproximar esses casos da definição de um erro por negligência, que aumentaria os riscos de efeitos iatrogênicos para o paciente.

Como terceiro ponto do modelo apresentado tínhamos as relações entre sujeito e sexo, que se articulam na construção de Lacan com dois elementos essenciais para esse jogo: a falta e a aposta. Como já mencionado, temos no polo sexual aquilo que promove um furo no saber e que abre uma via para acesso ao desejo. Vimos também a importância da atuação do analista neste processo, enquanto condutor desse jogo, situando sua regra e permitindo a possibilidade ao paciente de redistribuição das apostas em jogo, e também com a função de fazer operar o desejo do analista, permitindo ao paciente se situar em relação a seu próprio desejo.

Mas como visto, há algo de irredutível no polo do sexo, algo inacessível ao saber do sujeito, de modo que a solução desse impasse não passa exclusivamente pela via do saber, mas sim pela via do que foi colocado por Lacan como a aposta no jogo, ou seja, a possibilidade para o sujeito de fazer algo com esse impossível da relação sexual, se situar diante disso, em uma nova articulação ou arranjo entre os três polos (sujeito, saber e sexo), no sentido de um equilíbrio "mais puro", sendo essa justamente o índice maior do que se pode chamar de cura no tratamento psicanalítico.

Assim, algo da verdade sexual que se mostra impossível de ser acessado e que aponta para o sujeito sua falta e, em contrapartida, traz para o Sujeito - e também para o tratamento - a necessidade de momentos de aposta. Esse jogo de apostas que se estabelece a partir da incidência da falta segue também um determinado tempo. Trata-se de um tempo lógico e não cronológico, mas ainda assim um tempo, que deve ser respeitado para que as eventuais intervenções possam alcançar os efeitos desejados. Contudo, como em toda aposta, há riscos envolvidos. Se sabemos da importância para o tratamento de que o paciente tenha a possibilidade de se deparar com a falta, inerente ao impossível da verdade sexual, buscando através do trabalho analítico a possibilidade de abertura para a via do desejo, permitindo que faça essa aposta, reorganizando suas relações entre os três polos, por outro lado, é forçoso reconhecer que a possibilidade 
dessa aposta deve ser resultado e efeito de um trabalho analítico bem conduzido e que um eventual contato precipitado com esse impossível da relação sexual ou então uma forçagem para uma nova aposta precipitada podem ser muito disruptivos para o tratamento e para o paciente.

Trata-se dos casos em que uma ação muito apressada ou muito contundente por parte do analista, seja em uma interpretação, intervenção ou mesmo ato, se fazem em descompasso com o tempo do tratamento e com o tempo do paciente. Se há um lado de aposta do lado do paciente, há também uma aposta do lado do analista, sendo parte de seu ofício ser capaz de realizar uma leitura de como tem avançado o tratamento e de quais intervenções seriam possíveis em cada momento, a fim de sustentar a direção do tratamento. Se se trata de uma aposta por parte do analista, é certo que não há garantias plenas dos eventuais resultados. Contudo, isso não exime o analista de estar atento para os detalhes de cada situação clínica, para que possa realizar algum tipo de consideração acerca da possibilidade ou não de realizar uma intervenção, uma espécie de aposta calculada.

Sabe-se desde Freud (1913/1996), que a interpretação, por exemplo, comporta certa relação com o tempo: não se deve interpretar antes de estabelecida a transferência. Freud (1913/1996, pg. 87) nos alerta para os riscos de uma interpretação feita de modo precipitado logo no início de um tratamento: "Um comportamento deste tipo desacreditará completamente a nós e ao tratamento aos olhos do paciente e nele despertará a mais violenta oposição, (...). Via de regra, o efeito terapêutico será nenhum, mas o desencorajamento do paciente quanto à análise será definitivo.”

Mesmo uma vez estabelecida a transferência, as eventuais intervenções do analista devem, dentro do possível, estar situadas e articuladas com o fluxo e o contexto do tratamento no momento da intervenção. Sobre isso, Freud (1913/1996, pg. 87) continua: "Mesmo nos estádios posteriores da análise, tem-se de ter cuidado em não fornecer ao paciente a solução de um sintoma ou a tradução de um desejo até que ele esteja tão próximo delas que só tenha de dar mais um passo para conseguir a explicação por si próprio." 
Caso essa aposta por parte do analista se faça de maneira muito apressada ou descuidada, ou até mesmo de modo muito tardio, fora de compasso com o ritmo do paciente e do tratamento, teríamos um maior risco de que a intervenção seja mal sucedida, representando maior potencial iatrogênico para o paciente. Assim, uma interpretação apressada, selvagem, ainda que precisa, pode ser prejudicial, caso feita no momento inadequado. Uma intervenção apressada pode resultar em efeitos iatrogênicos para o paciente, o que exige cautela por parte do analista e a sensibilidade para mensurar quais seriam as apostas que devem ou não ser feitas e em quais momentos. Essa presença dos elementos do risco e do tempo nos permite a aproximação com o conceito de Imprudência. Assim, nas relações entre sujeito e verdade, neste jogo de apostas entre analista e paciente, quando algo não opera adequadamente, poderíamos situar as hipóteses de erro do analista por imprudência, representando maior potencial iatrogênico para o paciente.

Ainda no tema da imprudência, e tendo em vista a relação proposta com a questão do tempo no tratamento psicanalítico, resta um ponto essencial a ser retomado aqui.

Voltando à formalização proposta por Lacan, do tratamento psicanalítico como um jogo, vimos que há um ponto específico acentuado por Lacan: a função do analista no tratamento enquanto aquele que dirige o jogo mas, ao mesmo tempo, como aquele que deve dirigir este jogo para um fim, estando a possibilidade de dirigir o jogo ao fim intimamente ligada com a própria operação do desejo do analista no tratamento. Retomemos o que nos diz Lacan (1964-65/2006, pg. 358):

“(...) a astúcia do condutor do jogo, se o analista pode merecer esse nome, só pode ser por isso, por fazê-lo chegar ao fim, por desprender dessa defensiva uma forma sempre mais pura. E é isso que é o desejo do analista na operação."

Assim, temos uma questão crucial acerca do tempo e da condução do tratamento, bem como da dimensão de aposta envolvida, ante a importância indicada por Lacan, de que o analista possa, enquanto aquele que conduz o tratamento, propiciar 
este momento crucial, de redistribuição das apostas, a partir de uma referência a este objeto $a$ e ao desejo do sujeito, sendo tal procedimento efeito do próprio desejo do analista em operação.

Desse modo, se reconhecemos a importância vital de que se possa conduzir o jogo ao seu termo, é forçoso estar alerta para os casos em que algo deste desejo no analista não opera, em que esse fim não pode ser alcançado e em que, consequentemente, encontramos prejuízos para o processo de cura, possivelmente com efeitos iatrogênicos para o paciente.

No exemplo trazido por Lacan, neste Seminário 12, sobre a analista Pearl, que mesmo após 10 anos de trabalho com o paciente, não conseguia conduzir o tratamento de modo a promover um corte capaz de propiciar que o paciente pudesse se situar ante seu próprio desejo, temos indicativos do potencial iatrogênico envolvido quando não se consegue promover esse fim do jogo, que incita uma redistribuição das apostas. Sobre este ponto, teceremos maiores considerações no capítulo subsequente.

Enfim, condensando os desenvolvimentos propostos neste capítulo e considerando essa articulação entre os três polos (sujeito, saber e sexo) e as três modalidades de iatrogenias culposas (Imprudência, Imperícia, Negligência), poderíamos alterar o modelo proposto por Dunker (2015), para situar os riscos de iatrogenias no tratamento, conforme o quadro abaixo: 


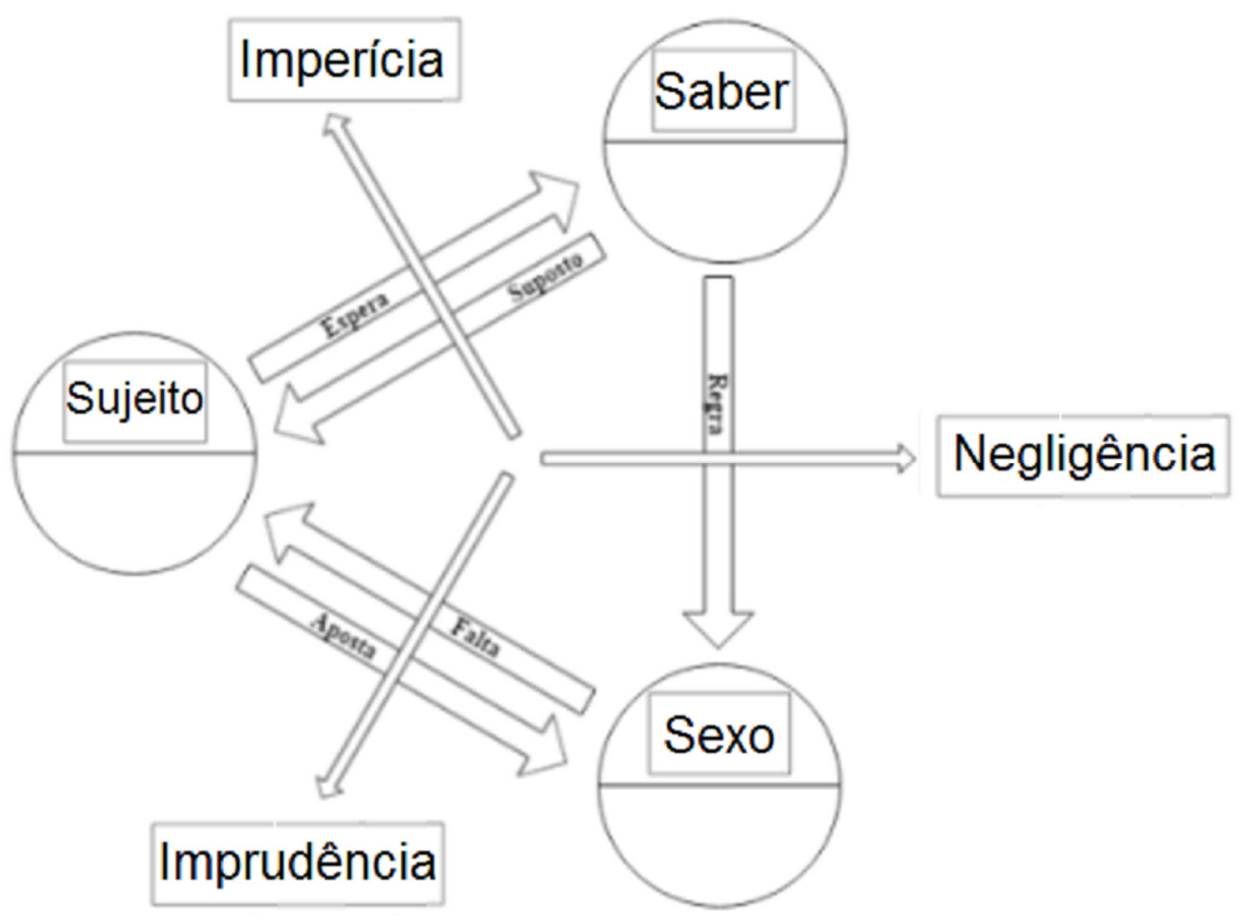

Figura 12: Articulação entre o jogo psicanalítico e as categorias iatrogênicas

A partir dessa proposta de modelo para situar os possíveis riscos de iatrogenia por erro do psicanalista na condução do tratamento, nos propomos, no capítulo subsequente, a discutir quais seriam, então, as possibilidades de pensar mecanismos que possam reduzir o potencial iatrogênico desse dispositivo analítico. 


\section{CAPÍTUlo 7 - A FORMAÇÃo do ANALISTA E AS POSSIBILIDADES DE REDUÇÃo DO POTENCIAL IATROGÊNICO DA PSICANÁLISE}

No capítulo anterior foi apresentada a proposta de formalização do tratamento psicanalítico apresentada por Lacan em seu Seminário 12, estruturando a prática psicanalítica à semelhança de um jogo, com base em três elementos - o sujeito, o saber e o sexo - que se articulam em uma relação de dominância circular. A partir do manejo das relações entre esses três elementos, o analista deve conduzir o tratamento, conduzindo o jogo ao seu final, de modo a possibilitar ao analisando uma via para uma redistribuição das apostas em jogo, ou seja, o estabelecimento de uma nova composição entre sujeito, saber e sexo, que seja mais próxima de sua relação com o objeto $a$ e, consequentemente, com seu desejo.

Tomando essa formalização lacaniana, seguimos com as articulações trazidas por Dunker (2015), para discutir as implicações que essa formalização pode trazer para pensar os diversos momentos de um tratamento psicanalítico. A partir desta apresentação, fizemos uma articulação com a questão do potencial iatrogênico do tratamento psicanalítico e, mais especificamente, com os riscos de ocorrência de erros culposos por parte do psicanalista na condução do tratamento, erros que, como visto anteriormente, podem ser classificados em três categorias: erros por imperícia, erros por negligência e erros por imprudência.

Vimos como cada uma dessas categorias podem ser articuladas às relações estabelecidas entre os três elementos do esquema: sujeito, saber e sexo. Nesse sentido, a ocorrência de erros por imperícia, na relação entre sujeito e saber, a partir do manejo inadequado da técnica psicanalítica e, mais especificamente, da transferência; os erros por negligência, na relação entre saber e sexo, quando algo da ordem de um narcisismo, interesse pessoal ou gozo do analista interfere no tratamento, representando um obstáculo ao processo de cura; e, por fim, os erros por imprudência, na relação entre sexo e sujeito, nos casos em que o analista se precipita, realizando intervenções ou 
apostas incompatíveis com o momento vivido pelo analisando no tratamento ou, ainda, quando algo da ordem de um gozo do analista intervém no tratamento, como um obstáculo que impossibilita que o tratamento chegue a seu fim.

Tais articulações nos permitem uma melhor compreensão acerca do potencial iatrogênico do tratamento psicanalítico, destacando quais seriam os momentos do tratamento mais sensíveis à ocorrência de efeitos iatrogênicos. Desse modo, espera-se que tais categorias possam contribuir diretamente para o avanço nas investigações sobre o potencial iatrogênico da psicanálise, ao oferecer ferramentas que permitam um retorno à clínica psicanalítica, com a análise e discussão de casos, visando identificar, classificar e compreender os possíveis efeitos iatrogênicos em curso em um tratamento, a partir da construção de casos clínicos. Porém, tal investigação mais aprofundada, com realização de um retorno ao âmbito da clínica psicanalítica e discussão de casos clínicos, fugiria ao escopo deste trabalho e não será realizada neste momento, ficando reservada para futuros desenvolvimentos.

Contudo, visando ainda cumprir a proposta deste trabalho, acreditamos necessário trazer algumas indicações acerca dos modos como os elementos levantados nesse trabalho, acerca do potencial iatrogênico da psicanálise, podem contribuir para que sejam pensadas vias de redução da ocorrência de efeitos iatrogênicos no tratamento, reduzindo assim, em última instância, o potencial iatrogênico do tratamento psicanalítico. Não se trata daqui de esgotar as vias de possíveis implicações que o tema pode produzir, mas apenas de indicar caminhos, vias de investigação que poderão orientar o avanço da pesquisa sobre o tema.

Ao se falar em tentativas de reduzir ou prevenir a ocorrência de certos fenômenos, estamos cientes dos riscos de que a discussão venha a recair em anseios orientados por um ideal utópico de controle da prática clínica e garantia de um exercício livre de riscos e de perigos. Assim sendo, cumpre aqui esclarecer que não se trata de seguir uma via normativa, pensando em mecanismos regulatórios ou sistemas de controle e fiscalização que tenham pretensões de garantir uma prática segura e livre de riscos. 
Como visto anteriormente, e reforçado insistentemente, o jogo psicanalítico envolve sempre uma dimensão de aposta, realizada a partir da singularidade de cada caso que se apresenta. Não se trata então de se iludir com um ideal de normatização que pudesse guiar uma prática psicanalítica livre de riscos, de apostas e de angústias. Pelo contrário. O objetivo deste capítulo não será de propor regras ou mecanismos de regulação, que possam engessar a prática psicanalítica em um modelo rígido e previsível, mas, pelo contrário, de tecer considerações a partir da questão da formação do psicanalista, evocando a responsabilidade assumida por cada analista ao se dispor a conduzir um tratamento e tomando em consideração às questões sobre o potencial iatrogênico do tratamento, visando uma revisão acerca dos modos de condução do tratamento.

Assim, se reconhecemos os perigos de um discurso que vise forjar garantias ao buscar um ideal de prática que exclua a dimensão da aposta, por outro lado, isso não significa aceitar que a prática clínica seja exercida de modo descuidado, impensado, desmedido ou irrefletido. Ao poder repensar sua prática psicanalítica, revisitar os conceitos propostos pela teoria, construir o caso em supervisão ou levar questões para sua análise pessoal, abre-se a para o analista a possibilidade de revisar constantemente a sua prática, tecendo novas elaborações que poderão subsidiar sua atuação futura. Tratase sim, no fazer psicanalítico, de uma dimensão de aposta, mas isso não quer dizer que isso se faça livre de cálculos. Há uma série de elementos a serem considerados pelo analista ao conduzir sua prática e realizar suas apostas, de modo que entendemos que a responsabilidade do analista se dá a partir da própria possibilidade de conduzir sua prática devidamente advertido das implicações que o poder de suas intervenções podem produzir sobre o sujeito, no curso de um tratamento. E isso inclui considerar também os possíveis efeitos iatrogênicos.

Destarte, se o de que se trata é de pensar na responsabilidade do analista e nos modos como pode estar advertido dos efeitos de sua prática, tomaremos aqui, como eixo de discussão deste capítulo, a questão da formação do analista.

Jerusalinsky e Sousa, em seu prefácio à edição brasileira do livro Jacques Lacan e a formação dos analistas (Safouan, 1985), ao apresentar a questão acerca da formação 
do analista, partem da máxima de Lacan de que "O psicanalista só se autoriza por si mesmo" (Lacan, 1967/2003), para debater este tema a partir de um questionamento acerca de qual seria a posição inconsciente ocupada por um psicanalista e que seria capaz de defini-lo como tal. Destacam que, sem dúvida, trata-se de algo que envolve a capacidade de dispor de um certo saber, o saber psicanalítico. Mas mais do que isso, trata-se, em relação a esse saber, de qual o uso que o psicanalista fará desse saber em sua prática. Pois, como vimos com Lacan e Safouan, a responsabilidade do psicanalista envolve também a possibilidade de saber ignorar o que se sabe, de modo a possibilitar a via de abertura para o inconsciente do sujeito que busca a análise.

A partir disso, Jerusalinsky e Sousa destacam três elementos centrais que configuram a formação de um psicanalista, ou, em outras palavras, como proposto por Lacan, a possibilidade de emergência deste desejo, o desejo do analista. Tais elementos propostos são: "Primazia significante, destituição narcísica e des-ser: operações formantes de um sintoma: ser analista" (Safouan, 1985, pg. 8). Tais elementos serão destacados para a discussão proposta neste capítulo

Mas, se reconhecemos que essas três operações são os efeitos a serem produzidos ao final do processo de formação de um analista, faz-se necessário também considerar quais seriam os dispositivos utilizados para alcançar esses objetivos. Neste sentido, cabe o recurso ao tripé clássico da formação do analista, como propostos desde Freud (análise pessoal, estudo teórico e supervisão clínica), bem como a posterior proposta lacaniana para formação de analistas que, não rompeu com o tripé, "mas deu a ele maior consistência, ao promover intervenções radicais em cada um de seus segmentos" (Jorge, 2006, pg. 9). Sobre essa questão do tripé de formação e as mudanças trazidas por Lacan, cabe uma pausa para discussão.

A prática de formação de psicanalistas a partir do tripé (análise pessoal, supervisão e estudo teórico) desde cedo foi adotada pelas diversas instituições de formação em psicanálise. Como indica Jorge: "Historicamente, desde que a formação psicanalítica passou a ser regulada pelos institutos de ensino de psicanálise, a análise chamada didática foi considerada o paradigma da formação do psicanalista, ao lado da 
supervisão e da frequência aos seminários sobre a teoria psicanalítica." (Jorge, 2006, pg. 285).

Mesmo até os dias atuais, é frequente o recurso a esses dispositivos, ainda que com variações acerca de seu funcionamento e obrigatoriedade. Como afirma Fontenele: "Trata-se de um consenso, a despeito das divergências entre as inúmeras instituições psicanalíticas existentes, que a análise pessoal, a pesquisa teórica e a supervisão são os três fulcros imprescindíveis à formação de um psicanalista.” (Jorge, 2006, pg. 263)

Mas se o recurso ao tripé de formação do analista se faz presente desde cedo na história da psicanálise, isso não significa dizer que tais práticas tenham sido realizadas da mesma maneira ao longo desse tempo. Pelo contrário, tais práticas sofreram mudanças ao longo da história da psicanálise. Não cabe aqui apresentar todo o percurso de desenvolvimento e mudanças nessas práticas ao longo da história das diversas instituições psicanalíticas. Indicaremos apenas, de modo geral, as alterações propostas por Lacan que, como vimos com Coutinho, não abandonou o tripé, porém inseriu alterações radicais em cada um desses dispositivos de formação. Saliente na fundamentação dessas mudanças uma preocupação de Lacan com o rigor na formação dos analistas e, consequentemente, na prática da psicanálise, a partir da experiência do inconsciente que a fundamenta. Ainda que não utilizasse o termo "iatrogenia", ao propor tais alterações, fica claro o tom crítico de Lacan ao modo como a formação de psicanalistas vinha sendo feita no âmbito da IPA, e acerca dos prejuízos que as questões institucionais produzidas pela IPA prejudicavam a formação dos analistas e, consequentemente, as análises conduzidas posteriormente por estes analistas. Neste sentido, Jorge afirma:

"Lacan, assim, revolucionou também a teorização psicanalítica e propôs que fossem repensados integralmente todos os dispositivos ligados à formação do psicanalista, chegando a afirmar, sob a forma de um chiste, que jamais falara de formação do psicanalista, mas sempre de formações do inconsciente. (...) Ao passo que a IPA concebia a formação analítica no modelo universitário como acesso a um saber, Lacan não só sublinhou o não-saber que está em jogo nessa formação, como abriu para esse não-saber um lugar de 
escuta. Ao agir assim, deu à formação analítica o rigor que lhe era exigido, pois radicalizou a experiência sem estabelecer "formações de compromisso" com outras experiências discursivas." (Jorge, 2006, pg. 286)

Mais uma vez, então, com Lacan, a importância de privilegiar essa experiência radical de não-saber na prática psicanalista. Mas em que consistiram as mudanças propostas por Lacan aos dispositivos de formação? Não iremos aqui esgotar todas as implicações e elementos envolvidos nas propostas lacanianas, mas apenas indicá-las, de modo a subsidiar as discussões posteriores. Neste sentido, seguimos com Jorge:

"Em primeiro lugar, caiu, para Lacan e para os que seguem seu ensino, a ideia de que há uma diferença entre análise didática e análise terapêutica. Para Lacan, toda análise é, essencialmente, didática, uma vez que sempre se trata, sendo esta de formação ou terapêutica, de ter acesso aos elementos da constelação simbólica inconsciente de um determinado sujeito singular." (Jorge, 2006, pg. 286)

Assim, a primeira mudança se deu no âmbito da análise didática, com abandono do modelo de análise didática proposta pela IPA, em que a análise do candidato a psicanalista era realizada de forma institucionalizada, burocrática e compulsória, conduzida por um analista didata vinculado à escola. A análise pessoal é mantida por Lacan como pressuposto essencial à formação do analista, mas agora livre dos entraves institucionais e obrigatoriedade propostos pela IPA (vimos no capítulo 4 alguns dos prejuízos trazidos pelo dispositivo de análise didática, como análises reduzidas apenas ao interesse do candidato em buscar a aprovação do analista e obtenção para si do título de analista). Continuando com Jorge:

"Em segundo lugar, caiu a ideia de supervisão obrigatória na formação do psicanalista. (...) A supervisão não perdeu sua função, mas foi acolhida em um dispositivo de formação mais livre, no qual o candidato a analista pode buscá-la adequando-a a suas necessidades pessoais, sem se submeter a um protocolo rígido que, 
no fim das contas, só faz escamotear para ele próprio suas insuficiências." (Jorge, 2006, pg. 286)

A segunda mudança então, no dispositivo de supervisão, também no sentido de propor um dispositivo livre dos entraves burocráticos e da obrigatoriedade propostos pela IPA. Assim, os problemas a serem atacados com essa mudança são semelhantes aos que subsidiam o fim das análises didáticas. Trata-se de buscar assegurar a experiência do inconsciente também nas supervisões, abrindo-se campo para incidência do não-saber, dos limites, em jogo na prática psicanalítica, sem o atravessamento de impasses institucionais. E por fim:

"Em terceiro lugar, pode-se ver que também caiu para Lacan, e para nós lacanianos, a ideia de uma formação analítica acabada, substituída pela ideia de uma formação analítica permanente, isto é, que é efeito de um trabalho contínuo, um work in progress, condizente com a ideia de que o mundo simbólico é infinito porque perpassado continuamente pelo real, não sendo possível concluí-lo de uma vez por todas." (Jorge, 2006, pg. 287)

Por fim, no âmbito do estudo teórico, a mudança envolve o fim da ideia de que a formação do analista pode ser submetida á um termo, a um prazo, a uma lista de prérequisitos que, uma vez cumpridos, produziriam um analista, pronto, completo, habilitado a enfrentar todos os desafios da clínica psicanalítica. Pelo contrário, a proposta lacaniana é de uma formação continuada, com constante aprimoramento e revisão dos conceitos psicanalíticos, mais uma vez visando propiciar a abertura para este furo no saber, que sustenta a prática psicanalítica.

A partir desses elementos pertinentes à formação do psicanalista, faremos alguns apontamentos acerca de que modo cada um desses eixos do tripé podem ser articulados aos riscos iatrogênicos apresentados no capítulo anterior e, até que ponto, são capazes ou não de responder à tarefa de reduzir o potencial iatrogênico do tratamento psicanalítico. Entendemos que a própria proposta do tripé, aceita e reconhecida até hoje, tem a função de formar analistas e aprimorar o modo como conduzem suas práticas. Assim como reconhecemos que as alterações propostas por Lacan produzem ainda 
outros avanços importantes para a formação do analista, com benefícios para a prática clínica. Assim não cabe aqui repisar ou revisitar todos os argumentos envolvidos na sustentação desse dispositivo. Mas, partindo da constatação de que o tema da iatrogenia ainda é pouco explorado no campo psicanalítico, a proposta deste capítulo é de partir do tema da iatrogenia para considerar de que modo os dispositivos de formação do analista respondem ou não às questões sobre o potencial iatrogênico da psicanálise vistas neste trabalho.

\section{ESTUdO TEÓRICO}

Começaremos nossa discussão por um primeiro elemento do tripé de formação do analista que é a formação teórica. Por vezes, o primeiro passo dado na formação, sendo comum que uma curiosidade ou contato com a teoria psicanalítica desperte o interesse na formação em psicanálise, até pela presença da psicanálise nos currículos universitários de cursos como o de psicologia. Mesmo nas escolas de psicanálise, é frequente que a formação se inicie com o estudo teórico, sendo o atendimento supervisionado de pacientes reservado para um momento posterior, até para que o candidato possa recolher um repertório mínimo acerca da prática psicanalítica, antes de iniciar seus atendimentos.

É evidente que a formação teórica, com o estudo da teoria psicanalítica, fornece ao psicanalista elementos vitais para a formação de seu raciocínio clínico e para que possa orientar seu manejo da técnica psicanalítica. Contudo, é importante interrogar de que modo esse saber teórico pode se articular ao fazer psicanalítico e quais os riscos envolvidos em uma incidência inadequada desse repertório teórico.

Sobre isso, poderíamos intuitivamente pensar numa série de casos em que o próprio conceito teórico é apreendido de modo equivocado pelo psicanalista e, depois, é aplicado também de maneira equivocada, induzindo-o a erro em seu raciocínio clínico e na condução do tratamento. Podemos pensar numa má compreensão acerca das estruturas clínicas que resulte em equívoco diagnóstico, ou entendimento errado acerca 
de determinados mecanismos de resistência que acabem prejudicando os manejos realizados, equívocos acerca dos conceitos de interpretação e transferência que resultem em prejuízos à relação transferencial... enfim, uma série de hipóteses, que não nos cabe aqui esmiuçar ou esgotar. São casos em que o problema não está exatamente na relação entre teoria e prática, mas sim numa falha na apreensão deste repertório teórico.

Ao invés disso, o que pretendemos discutir aqui é a relação que se estabelece entre o conteúdo teórico e a prática clínica, ou seja, mesmo para os casos em que o psicanalista tenha uma compreensão adequada dos conceitos da teoria psicanalítica, de que modo tal saber deve ser articulado à prática clínica. Neste ponto, imperativo resgatar os desenvolvimentos tecidos no capítulo anterior acerca das relações entre o sujeito, o saber e o sexo.

Foi exposta no capítulo anterior a crítica de Lacan à ciência moderna, ao tratar o saber teórico como um saber ilimitado, capaz de ser acumulado e que visa responder à totalidade das coisas, compondo um saber universal. A partir dessa crítica, Lacan destaca a importância da incidência deste terceiro elemento, do sexo, do impossível da relação sexual, o impossível de saber, que promove um furo nessa pretensão universalizante do saber científico. Indo além, destaca que é justamente nesse furo, nessa fresta aberta pelo sexo no saber, que se vislumbra a possibilidade de emergência do sujeito.

Assim, um primeiro ponto de indicação é que não se trata de utilizar a teoria psicanalítica como se fosse um saber típico da ciência moderna, um saber teórico que se aplica sobre o objeto, compondo uma prática livre de incertezas. Pelo contrário, na psicanálise o que temos, como nos adverte Lacan, é uma relação muito singular entre a teoria e seu objeto, sendo vital que haja sempre abertura para revisão dos conceitos, conforme os avanços na prática clínica.

Neste mesmo sentido, resgatamos os dois pressupostos fundamentais colocados por Lacan nesse Seminário 12: (i) a definição de que o significante é o que representa o sujeito para outro significante; e (ii) o estatuto do lugar do analista no tratamento, enquanto lugar de sujeito suposto saber. Do primeiro pressuposto, resgatamos essa 
mesma ideia, de que é na vacilação da cadeia significante, nesse descompasso da relação significante que pode emergir o sujeito. Do segundo pressuposto, com a ideia de sujeito suposto saber, uma indicação acerca do modo como o psicanalista se situa diante do saber no tratamento psicanalítico. Ou seja, trata-se aqui de que o analista esteja advertido de sua posição de suposição de saber, suspendendo o que sabe, para que, a partir da fala do sujeito, e nos tropeços do significante, possa emergir algo de novo, algo do sujeito que busca o tratamento.

Para avançar nesse tema, recorremos ainda a dois elementos fundamentais da técnica psicanalítica, como proposta por Freud: a regra da associação livre para o paciente; e a atenção flutuante para o analista.

Este primeiro ponto, da regra da associação livre, é considerado, desde Freud, como a regra fundamental para a psicanálise (Freud, 1912b/1996), chamada também de "regra de ouro" da psicanálise, constitui o fundamento que possibilita o tratamento psicanalítico, e também que constitui a originalidade desse método, ao propor que o paciente possa associar livremente, comunicando ao analista tudo que lhe vem à mente durante a consulta. Neste sentido, Moretto (2013, pg. 32): "O procedimento freudiano não deixou margem a dúvidas sobre 'o que fazer' do paciente. Ele tem a sua regra fundamental e, ainda que decida por não falar, o que tem de fazer, se quiser se analisar, é associar livremente.”.

Sobre a associação livre, Freud (Freud, 1913/1996, p. 149-150) ensina:

"Observará que, à medida que conta coisas, irão lhe ocorrer diversos pensamentos que gostaria de pôr de lado, por causa de certas críticas ou objeções. Ficará tentado a dizer a si mesmo que isto ou aquilo é irrelevante aqui, ou inteiramente sem importância, ou absurdo, de maneira que não há necessidades de dizê-lo. Você nunca deve ceder a estas críticas, mas dizê-lo apesar delas [...]. Assim diga tudo o que lhe passa pela mente"

Se, do lado do paciente, o que temos é a regra da associação livre, cabe questionar o que cabe ao analista, diante dessa fala em associação livre por parte do paciente. Assim, como contrapartida do analista, temos então o segundo elemento 
destacado por nós: a atenção flutuante. Sobre esta correspondência entre a associação livre e a atenção flutuante, Moretto (2013, pg. 32) comenta:

"E, o analista, o que tem de fazer? Diferentemente do seu paciente que não fica sem saber o que tem de fazer, Freud não deixou para o psicanalista uma regra fundamental. Poderíamos entender como o correspondente da regra fundamental da associação livre do paciente o que Freud chamou de atenção flutuante."

Essa ideia pode mesmo ser localizada em Freud (1912b/1996, pg. 125-126), quando afirma: "Ver-se-á que a regra de prestar igual reparo a tudo constitui a contrapartida necessária da exigência feita ao paciente, de que comunique tudo o que lhe ocorre, sem crítica ou seleção. Se o médico se comportar de outro modo, estará jogando fora a maior parte da vantagem que resulta de o paciente obedecer à 'regra fundamental da psicanálise'.”

Pela atenção flutuante do psicanalista, abre-se a capacidade de escutar a fala em associação livre do paciente, sem se deixar tomar por preconceitos ou preconcepções que venham a privilegiar certos elementos do discurso em detrimento de outros. Neste sentido, Freud (1912b/1996, pg. 126) indica:

"A regra para o médico pode ser assim expressa: 'Ele deve conter todas as influências conscientes da sua capacidade de prestar atenção e abandonar-se inteiramente à 'memória inconsciente'.' Ou, para dizê-lo puramente em termos técnicos: 'Ele deve simplesmente escutar e não se preocupar se está se lembrando de alguma coisa."”

Neste sentido também a definição encontrada em Laplanche e Pontalis (1977, pg. 74) para a atenção flutuante:

"Modo como, segundo Freud, o analista deve escutar o analisando: não deve privilegiar a priori qualquer elemento do seu discurso, o que implica que deixe funcionar o mais livremente possível a sua própria atividade inconsciente e suspenda as motivações que 
dirigem habitualmente a atenção (...) consiste numa suspensão tão completa quanto possível de tudo aquilo que fiscaliza habitualmente a atenção; inclinações pessoais, preconceitos, pressupostos teóricos mesmo dos mais bem fundamentados".

E neste ponto encontramos uma reaproximação ao assunto de nosso interesse: a relação do analista com a teoria psicanalítica. Laplanche e Pontalis indicam a importância de que sejam suspensos até mesmo os "pressupostos teóricos mesmo dos mais bem fundamentados". Eis aí o impasse que se apresenta à relação entre a prática psicanalítica e a teoria psicanalítica. Por um lado, o reconhecimento da importância do estudo teórico para a formação do analista. Por outro lado, a importância de que esse conhecimento possa ser suspenso, possibilitando a escuta livre do paciente. Sobre essa questão, Moretto (2013, pg. 33) destaca o caráter paradoxal:

"Ou seja, escutar sob atenção flutuante é um paradoxo prático, pois o ideal não coincide com o real. Parece que o que Freud propõe é uma espécie de ignorância: alguém que sabe coisas mas que, voluntariamente, apaga até certo ponto seu saber para dar lugar ao novo que vai ocorrer. Essa não é uma tarefa simples para uma pessoa."

Neste trecho podemos encontrar a articulação com o que mencionamos anteriormente, sobre a relação com o saber. Mais especificamente, com a articulação de que é na possibilidade de promover um furo ou suspensão no saber que se abre via para emergência do sujeito. Assim, o que temos é que, para o psicanalista, em sua relação com a teoria psicanalítica, trata-se da capacidade de poder também suspender esse saber, ignorar o que sabe, para que assim se abra a via de acesso ao novo, ao inesperado, ao que é da ordem do inconsciente desse sujeito que comparece ao tratamento e que associa livremente.

Da articulação desses dois elementos: associação livre e atenção flutuante, e da necessidade de que o analista possa suspender seu saber ao escutar o paciente, podemos resgatar o primeiro dos elementos trazidos por Jerusalinsky e Sousa, como habilidades necessárias a um analista: a capacidade de operar em função da primazia significante. 
Neste sentido afirmam: “Assim, na Direção da Cura e os Princípios de seu Poder, Lacan pontualiza, na análise e crítica dos usos da transferência, a posição do analista como a de alguém em quem se estabelece a primazia do significante como o ponto capital de sua relação com Outro, e não os aspectos imaginários” (Safouan, 1985, pg. 8)

A partir dessas considerações, podemos visualizar os riscos iatrogênicos que podem resultar deste primeiro eixo da formação: o aprendizado teórico. O risco aqui é de que o psicanalista venha a assumir uma posição de adesão excessiva à teoria, submetendo todo o escopo da clínica à égide do campo teórico, tomado de modo dogmático, como uma teoria do diagnóstico, uma teoria da queixa, uma teoria do sintoma, etc. Se agarrando à certeza de um saber capaz de a tudo responder, eliminando quaisquer possibilidades de dúvidas, angústias ou incertezas e bloqueando assim o acesso ao inconsciente deste que paciente que o procura para análise.

Ou seja, o analista orientado por uma equivocada crença de que se trataria, na clínica psicanalítica, de primeiramente resolver todos os impasses teóricos, na busca por uma teoria perfeita e bem acabada, capaz de apreender a totalidade de sua prática, solucionando, assim, de modo apriorístico, qualquer tipo de possível impasse ou risco iatrogênico. Vale aqui lembrar das pesquisas de Crown (1983), discutidas no capítulo 3 desse trabalho, que destacava os riscos iatrogênicos envolvidos em um apego excessivo do terapeuta aos preceitos teóricos.

Assim, neste caso de se tomar a teoria como tábua de salvação, capaz de responder a todas as questões, corre-se o risco de manter a teoria numa posição de idealização. Aliás, de fato, a etimologia da palavra "teoria" está ligada ao sentido de contemplação, até mesmo de beatitude, como atividade desinteressada, contraposta à prática, numa visão intelectiva, racional e abstrata (Pereira, 2003). Tal discussão tem interesse especial para o psicanalista, dado que a psicanálise enquanto práxis visa não apenas conhecer, mas transformar.

O material clínico que emerge na situação clínica é trabalhado por cada profissional, psicanalista ou não, conforme certas escolhas fundamentais a partir da linha teórica de sua preferência, mas que podem parecer o máximo de arbitrariedade ou 
falta de rigor aos adeptos de outro sistema conceitual. Por outro lado, é certo também que a multiplicidade de teorias poderia nos colocar frente a uma indeterminação improdutiva, com o pressuposto de igualá-las num ecletismo estéril ou ainda, como defesa a essa dispersão, adotar uma postura de dogmatismo - duas atitudes que bloqueiam o encontro com a diferença e com a alteridade, resultando em prejuízos para a prática clínica (Figueiredo, 1989). Cabe lembrar aqui a crítica feita por Maleval (2004), vista no capítulo 5, sobre abordagens integrativas, que propõe a equivalência entre as diversas técnicas, que poderiam ser usadas de modo intercambiável, sem maiores considerações acerca dos pressupostos epistemológicos de cada uma.

Lembra-nos Mezan (2002) que a diferença entre uma corrente teórica e outra está na teoria e nas habilidades que cada corrente oferece aos seus adeptos para que possam descrever, aprofundar, compreender e solucionar certos fenômenos da clínica sobre os quais terão que se posicionar. Contudo, nesse ponto, é preciso dizer que o que queremos evitar é que os efeitos nocivos do tratamento sejam absorvidos por uma narrativa que justifica seus meios aos seus fins, ou seja, ainda que reconhecendo que a teoria oferece um repertório ao psicanalista para que possa lidar com desafios que se apresentam na clínica, não se pode buscar reduzir à prática clínica à mera aplicação de conceitos teóricos sobre os fenômenos que se apresentam. E, num risco maior ainda, utilizar a teoria como via de justificativa para qualquer tipo de abuso ou equívoco realizado na condução do tratamento. Ao tomar a teoria como único balizador a orientar a prática clínica cria-se uma situação que, muito provavelmente, resultará em tentativas forçadas de subjugar o caso clínico aos preceitos teóricos, certamente com efeitos nocivos para o paciente. Pior do que isso, tal posição de idealização da teoria pode levar o analista a insistir no erro, buscando na teoria as justificativas ou álibis para legitimar sua prática equivocada.

Pelo contrário, o que se espera do analista é que possa estar sempre advertido para assegurar a abertura para que algo do inesperado, do imprevisível, do singular de cada sujeito, possa emergir no tratamento, ainda que isso possa se mostrar contrário ou diverso do que relatado pela teoria. 
Nesse sentido, o próprio modo de construção do saber psicanalítico, oriundo da prática clínica, coloca os conceitos psicanalíticos num modo de relação singular com a história da psicanálise, uma vez que ao longo dessa história, com a decantação de problemas, fracassos, impasses e soluções, é que se torna possível o avanço na teoria. $\mathrm{E}$ nisso cabe a cada psicanalista se posicionar frente à história da constituição da psicanálise e seus conceitos, visto que toda teoria emerge de uma/na práxis incluindo a história de seus acertos e erros como efeito de campos de forças heterogêneos.

Assim, um psicanalista, ao operar pelo chamado discurso do analista, está assentado sobre, no mínimo, 100 anos de psicanálise e isso quer dizer alguma coisa. A psicanálise não tem seus conceitos acabados, pelo contrário, tais conceitos são revisitados constantemente pelo psicanalista, a cada tratamento que conduz. No curso de sua formação e de sua prática, o psicanalista terá que lidar com uma literatura que encontrou avanços ou não a partir de sucessos e problemas oriundos da teoria (enquanto método clinico que visa propor uma semiologia norteadora do que é possível dar a ver) em sua relação com a terapêutica (que procura dar conta de transformações efetivas) e com a ética (que procura dar conta da relação entre fins e meios).

Desse modo, a partir de casos de erros ou impasses na prática clínica, é buscada a construção de novos saberes, atualizando a teoria psicanalítica, visando o avanço nos tratamentos conduzidos. É na constante reinvenção dos saberes e fazeres psicanalíticos, na articulação entre teoria e prática clínica, que se encontram as vias para avanço da prática psicanalítica. Fechar as possibilidades para que algo de inédito possa emergir na clínica psicanalítica seria impedir também que a própria teoria psicanalítica possa avançar. Consequentemente, é também nessa relação entre teoria e prática que se podem encontrar vias para a redução do potencial iatrogênico do tratamento.

Para isso, porém, não basta uma relação rigorosa entre prática e teoria, na qual a primeira se reduz à segunda, ou seja, a prática nada mais é do que aplicação do conteúdo teórico ao caso concreto. Pelo contrário, é necessária a possibilidade de abertura para esse terceiro elemento, para o furo no saber, para o impossível de saber, na sustentação da ética psicanalítica, a partir de sua especificidade enquanto método de tratamento, orientada pela primazia do significante e na possibilidade de que o sujeito e 
sua singularidade possam emergir a partir desse jogo significante, o que traz impactos para a direção do tratamento e objetivos almejados. Neste sentido, Fontenele: "O psicanalista opera analiticamente, e tão-somente, de sua posição de não-saber em face da realidade clínica, cabendo-lhe a postura de eterno aprendiz, algo que tem como uma de suas consequências a perspectiva da formação psicanalítica como devir.” (Jorge, 2006, pg. 267)

Como vimos, a proposta Lacaniana de uma formação continuada - em oposição ao modelo da IPA, de uma formação que tem um prazo previsto para se encerrar - visa algum tipo de solução para esta problemática, fundamentada na ideia de que uma formação continuada pode abrir constantemente ao psicanalista a possibilidade de revisitar a teoria psicanalítica e seus conceitos, com novas possibilidades de compreensão e articulação dos conceitos. Contudo, como vimos acima, não se trata exatamente da apreensão que se faz dos conceitos, mas sim do uso feito da teoria na clínica, ou seja, de que modo o psicanalista articula teoria e prática.

Neste sentido, podemos pensar em alguns riscos que ainda se fazem presentes quanto à formação teórica do psicanalista, mesmo a partir de um dispositivo lacaniano. Em primeiro lugar, a indicação de uma formação continuada de modo algum garante uma relação mais produtiva com o campo teórico. Inclusive, pode ocorrer o contrário: que tal proposta estimule ainda mais uma compulsão pela acumulação de mais repertório teórico, de mais construções e saberes, buscando sempre extrair dos conceitos as respostas para todos os impasses da clínica psicanalítica, algo que, por vezes, leva inclusive a abusos e distorções dos conceitos e das referências textuais numa tentativa forçada de que possam dar conta de novos desafios clínicos. Tais aspectos podem estar relacionados às críticas que escolas de orientação lacanianas enfrentam com certa frequência acerca de seu dogmatismo, isolamento e pouca interlocução com autores de outras orientações teóricas.

Podemos também pensar em outro efeito colateral desse modelo de formação continuada e excesso de dogmatização, que pode ser de uma maior dificuldade para que o jovem analista possa se autorizar, seja diante de seus pares, seja na condução de sua prática clínica. Podemos pensar aqui no que foi mencionado no capítulo anterior, acerca 
de analistas que nunca "fazem sua jogada", apenas esperam e escutam o paciente, acumulando mais e mais saber mas também aumentando crescentemente a angústia do paciente, não realizando nenhuma intervenção e produzindo efeitos iatrogênicos para o paciente.

Assim, a hipótese a ser explorada é de que o modo este tripé da formação analítica, o do saber teórico, é conduzido nas escolas lacanianas, com essa proposta de formação interminável, e por vezes com excesso de rigor e dogmatismo na apresentação dos conteúdos teóricos, possa ter um efeito colateral ou efeito reverso, de dificultar que o jovem analista possa se autorizar a operar com esses conceitos, seja em seu papel no âmbito da escola, seja diante de um paciente. Tomado pela dúvida e insegurança ante esse saber que se impõe de modo tão incisivo, o jovem psicanalista se cala, com efeitos deletérios para sua formação e, consequentemente, para seus pacientes. Trata-se de uma hipótese acerca de um problema institucional para as escolas de psicanálise e que justificaria maiores pesquisas nesse sentido.

Sobre isso, podemos ainda remeter o leitor ao dossiê Psicanálise: marginal? (Leite \& Goldenberg, 2015), projeto organizado por Nina Leite e Ricardo Goldenberg, que se propôs a reunir jovens analistas da cidade de São Paulo para elaborarem este dossiê com temas da psicanálise, em sua tensão com a formação oferecida pelas escolas de psicanálise. Em um dos verbetes inseridos no dossiê é assim apresentada a questão da "clínica miúda", nas escolas de formação lacanianas:

"Nesses debates, os conceitos devoram nossas pequenas dificuldades transformando-as em deficiências formativas ou erros de compreensão. Os projetos clínicos e as concepções diagnósticas distintas não encontram termo de comparação que não a gerada pela autoridade do supervisor e da escola na qual esta se apoia. (...) Como resultado, temos uma clínica cada vez mais miúda, submetida à teoria já enunciada por Freud e Lacan, sem ousar questioná-la. Entre os analistas lacanianos, o fascínio pela teoria provoca um distanciamento cada vez maior do sofrimento de seus analisandos. (...) $\mathrm{O}$ que vemos frequentemente nas instituições de transmissão da psicanálise lacaniana são discussões estéreis, que apenas reforçam o que já foi dito ou escrito e acabam por expulsar 
a novidade que a experiência clínica traz. Como resultado temos uma clínica cada vez mais miúda, tímida, espremida entre a lógica e a topologia." (Leite \& Goldenberg, 2015, pg. 36)

Um segundo risco no tocante à formação do analista e sua relação com o saber diz respeito à crescente presença de psicanalistas nas universidades. Nos últimos anos, temos visto uma maior presença de psicanalistas lacanianos nas universidades. Contudo, se vimos acima o esforço dedicado por Lacan para livrar a psicanálise de amarras institucionais capazes de reduzir a experiência psicanalítica a um processo burocrático de acumulação de saberes e preenchimento de requisitos, há de se questionar os riscos envolvidos nesse retorno dos psicanalistas às instituições de intuito formativo, agora as universidades. Assim, a entrada de analistas nas universidades, por um lado, tem a vantagem de promover uma difusão da psicanálise, articulação com outros discursos e acesso a mais pessoas, por outro lado, tal inserção coloca questões acerca dos impactos sobre a formação do analista, com o risco de que a psicanálise venha ser subjugada pelo discurso universitário ou que as antigas burocracias propostas pela IPA venham a ser substituídas por modelos novos como na crença de que a obtenção de títulos como de mestre ou de doutor numa universidade possam servir como algum tipo de garantia para formação do analista. Pode-se perceber um papel cada vez mais relevante da universidade na formação de jovens analistas, mas nem sempre tal transmissão se dá com a consideração acerca dos riscos envolvidos numa transmissão da psicanálise que se aproxime de um discurso universitário.

\section{SUPERVISÃO}

Além da formação teórica, um segundo elemento que sustenta o reconhecido tripé da formação do profissional é a busca por um profissional mais experiente para realização de supervisão dos atendimentos clínicos conduzidos, o que, logo de partida, pode aparecer como uma possível saída para aprimorar o modo como o analista conduz seus tratamentos, e assim minimizar possíveis efeitos iatrogênicos. Como nos indica 
Fontenele (Jorge, 2006), "mais experiente" talvez não seja o melhor critério, vez que o maior tempo de prática clínica não é necessariamente critério para estabelecer a capacidade de atuar como supervisor. Para sustentar esse argumento indica que Freud na verdade se refere à "psicanalistas reconhecidos", ou seja, aquele que, de algum modo, teve sua formação como analista reconhecida, sendo colocado numa condição específica em sua relação à psicanálise que o possibilite ocupar também o lugar de supervisor.

Ainda com Fontenele (Jorge, 2006), temos que a literatura existente sobre o tema da supervisão não é muito ampla, ainda que se trate de um dos pilares da formação do analista. Além disso, dentre as publicações existentes, a maioria diz respeito à formalização institucional das supervisões nas diversas escolas ou abordam questões técnicas sobre como decidir quem estaria habilitado a conduzir uma supervisão ou casos em que o candidato deve ou não ser aceito para supervisão.

Neste âmbito dos procedimentos institucionais acerca da supervisão nas escolas de psicanálise, acreditamos que muito do que já foi apresentamos anteriormente sobre as diferenças entre o modelo da IPA e o modelo lacaniano podem ser aplicadas. O modelo da IPA, ao propor a supervisão como dispositivo obrigatório e vinculado às exigências para que o candidato alcance o título de analista acaba por burocratizar a supervisão, reduzindo-a a uma prática institucionalizada e limitando seu alcance no que diz respeito à experiência do inconsciente. Além disso, o caráter obrigatório pode resultar numa prática de supervisão apenas para "cumprir tabela", mostrando completamente improdutiva.

Neste sentido, a proposta lacaniana, ao sugerir uma supervisão livre de amarras institucionais, visa contornar esses efeitos nocivos produzidos no âmbito da instituição. Sobre esse ponto é possível encontrar diversas literaturas que abordam de maneira aprofundada o tema, não sendo objetivo aqui insistir sobre esse ponto. Concordamos com Lacan, acerca do potencial iatrogênico que o dispositivo de supervisão compulsória pode produzir e os avanços trazidos por uma supervisão mais livre. Porém, discutiremos aqui outros aspectos que ainda persistem como possíveis limites ou críticas ao dispositivo de supervisão. 
Um primeiro ponto diz respeito a uma crítica ao modo como o dispositivo de supervisão é articulado, frequentemente fechado, restrito a supervisor e supervisionando. Tal dispositivo produz um contexto hermético cujos efeitos precisam ser considerados. Por um lado poderíamos supor que um ambiente assim, mais fechado, mais íntimo, facilitaria o trabalho do supervisionando, de poder relatar suas dúvidas, incertezas e falhas, o que talvez fosse mais difícil diante de uma audiência maior. Mesmo essa primeira hipótese já é questionável. Se por um lado um ambiente a dois é mais íntimo, por outro lado isso pode reforçar problemas transferenciais entre supervisor e supervisionando. Sobre isso falaremos mais na continuidade do texto. Um segundo problema é que esse modelo mais fechado não favorece a circulação dos temas e questões tratados. Aqui, cabe relembrar o que vimos acima acerca da "clínica miúda". Em que medida o dispositivo de supervisão, do modo como é proposto, não colabora também para a perda de espaço da dimensão clínica nos debates das escolas?

A indicação de Fontenele (Jorge, 2006), acerca da pouca literatura existente sobre o tema da supervisão pode também estar relacionada a isso. Como vimos no capítulo 2, a pesquisa sobre o tema da iatrogenia encontra como um de seus obstáculos a escassa literatura sobre o tema, sendo raros os relatos de casos de fracasso ou insucesso presentes na literatura. Acreditamos que a pouca literatura sobre os casos de fracassos e ocorrência de iatrogenias no curso do tratamento se deve também, em parte, ao fato de que tais ocorrências são especialmente recolhidas no âmbito da supervisão, enquanto lugar privilegiado de confidencialidade entre terapeuta e supervisor, no qual se acolhem os fracassos e se direciona a busca por modos de mitigar ou contornar esses fracassos, mas tudo isso feito de modo fechado, não compartilhado com a comunidade psicanalítica.

Em um nível mais amplo, ainda que casos de fracasso consigam ser discutidos em supervisão, nem sempre há a decisão por levar tais casos ao conhecimento de outros membros da comunidade, ficando o ocorrido restrito à confidencialidade entre terapeuta e supervisor. Como já mencionado, isso tem por efeito restringir o debate acerca dos riscos, erros e fracassos envolvidos no tratamento psicanalítico, dificultando o avanço de discussões acerca do potencial iatrogênico do tratamento. Desse modo, são 
frequentemente publicados e transmitidos os casos clínicos de sucesso, mas com que frequência vemos casos de fracasso ou erro?

Vimos no capítulo 4 que uma das principais medidas para redução dos efeitos iatrogênicos é que esses casos de iatrogenia possam ser levados aos colegas de profissão e discutidos abertamente. Neste sentido, o dispositivo de supervisão, ao recolher esses momentos de erro em um ambiente fechado, restrito à relação entre supervisor e supervisionando, podem acabar por reduzir o acesso a tais casos, reduzindo também possibilidades de avanços nas pesquisas sobre o tema e, consequentemente, na busca por avanços.

Por fim, é forçoso considerar ainda outro efeito dessa relação fechada de supervisão. É frequente que a demanda de supervisão seja direcionada a alguém com quem se compartilhe uma afinidade teórica e certo alinhamento em termos de prática clínica. Busca-se muitas vezes aquele com o qual se tem certa identificação. Mas esse alinhamento em termos de concepções teóricas ou práticas clínicas, atrelado a um dispositivo fechado, que reduz o diálogo a duas pessoas, pode acabar por promover um ambiente viciado, com pouquíssima abertura para outros tipos de argumentos ou propostas clínicas. O efeito é que isso pode produzir uma leitura viciada dos fenômenos que se apresentam na clínica, possivelmente transmitindo e reproduzindo, de supervisor para terapeuta, de geração para geração, certos tipos de práticas e, consequentemente, também certos tipos de iatrogenias e abusos do poder inerentes ao tratamento, que se reproduzem via certos ideais teóricos e normativos ou padrões de conduta, que podem se reproduzir e se perpetuar, quando não submetidos ao debate com outros interlocutores e não submetidos ao crivo de outros profissionais.

Neste sentido, acreditamos que seria válida uma investigação acerca da relevância de outros dispositivos relacionados à prática clínica, como grupos de supervisão e construção de casos clínicos, com membros que tenham uma relação mais horizontal entre si, e com propostas clínicas ou percursos de formação mais variados, "diluindo" assim também as transferências. O estímulo às reuniões clínica e apresentação de casos, não apenas os de sucesso, mas também os de impasses ou fracassos vividos na clínica. Não que esses dispositivos precisem substituir o modelo 
tradicional de supervisão, mas que possa ser reconhecida a importância de articulação destes outros espaços que promovem uma maior circulação da palavra e uma maior variabilidade de concepções clínicas, estimulando um debate mais rico e produtivo.

Além desses pontos, tal modelo fechado de supervisão pode também colaborar para perpetuação dos casos de iatrogenias, por conta do que foi indicado acima: as relações transferenciais entre as partes envolvidas. Entendemos que um ponto vital a ser considerado, ao se abordar o tema das supervisões, está na relação transferencial que se estabelece entre supervisor e supervisionando.

Se, como apontamos, a relação terapêutica se configura numa certa assimetria entre paciente e terapeuta, também na supervisão tal assimetria se reproduz, ao se configurar como um dispositivo em que um terapeuta mais jovem, menos experiente, menos reconhecido, busca supervisão junto a um profissional mais experiente e reconhecido e que, de algum modo, ocupa uma posição de saber e transmissão de um fazer sobre a clínica. Tal montagem pode facilmente resultar em efeitos de mestria e reprodução de modelos já viciados de prática clínica, que favorecem a ocorrência de iatrogenias.

Claro que, como já visto, tal situação pode se agravar ainda mais quando tal relação se dá no interior de instituições, como, por exemplo, nas escolas de psicanálise, que favorecem a reprodução de efeitos de grupo e estabelecimento de líderes (Safouan, 1985), com exigência de supervisões obrigatórias com os supervisores autorizados pela escola, tornando a prática clínica uma transmissão viciada de valores normativos, ou no caso das supervisões nas universidades, que podem ser reduzidas ao mero cumprimento de créditos e cargas horárias para obtenção do diploma.

Mas isso não quer dizer que, uma vez eliminadas quaisquer implicações institucionais, realizando uma supervisão desvinculada da instituição, como propõe Lacan, o problema estaria resolvido.

Em primeiro lugar, o fato de que uma supervisão transcorra fora do âmbito da escola de psicanálise ou da universidade não é de modo algum garantia de que essa supervisão não assuma um caráter excessivamente didático, no sentido de uma 
imposição de saber, do supervisor para o supervisionando, que exclui a possibilidade que este possa repensar sua prática clínica, seus alcances e limites, produzindo algo de novo. Neste sentido, Safouan defende que, o que há da ordem de uma aprendizagem na supervisão, não se trata de uma didática enquanto mera transmissão de um saber mas sim que: "essas poucas observações sobre o sentido da supervisão como aprendizagem, e que se resumem no fato de que se trata de aprender a aprender com sua própria experiência, único mestre no final das contas" (Jorge, 2006, pg. 280).

Assim, necessário cuidar para que a supervisão não tome a forma apenas de um ensino, em que o supervisor "atribui a si a reputação de ter não sei que tipo de 'faro' ou 'faculdade intuitiva', tornando-o apto a dar resposta a tudo e a encontrar o 'truque' que dissipa toda dificuldade como se fosse um passe de mágica" (Jorge, 2006,pg. 283), transmitindo um saber pronto e acabado ao supervisionando e que seria a resposta para todas as angústias da clínica. Pelo contrário, trata-se da possibilidade de permitir que o supervisionando possa rever sua própria prática clínica para que, a partir daí, possa ocorrer algum aprendizado. Mais uma vez, a ideia que tem permeado toda nossa discussão: que se possa permitir um espaço de furo no saber, que produza algo de inédito para o sujeito.

Em segundo lugar, para além da questão didática, persistiria ainda, em todo caso, a questão da relação transferencial entre as partes. Mais do que isso, acreditamos que há algo a ser discutido acerca do caráter de confidencialidade mantido nas supervisões, semelhante ao compartilhamento de um segredo ou até mesmo de confissão que um eventual erro no tratamento pode assumir, quando contado pelo supervisionando ao supervisor. Neste sentido, podemos lembrar o artigo de AlainDidier Weil quando, ao tratar da supervisão, o faz a partir da questão da confissão:

"Em duas palavras, direi que o risco de confessar é o risco de que o outro nos barre. Quando confesso, o outro me barra. E com propriedade. Então, sou realmente barrado, dividido. Na confissão, portanto, o que se passa é a revelação da divisão." (Jorge, 2006, pg. 258) 
A partir disso, o proposto por Weil é que o que transcorre na supervisão deve ser da ordem de uma confissão, sendo o supervisor aquele que produz no supervisionando um certo receio, ou uma certa vergonha, ao interpelá-lo com um olhar capaz de barrá-lo, levando-o à confissão. Neste sentido:

"Eis então o momento em que, no controle, reencontra-se esse problema. Em outras palavras, se o controle se passa, uma vez mais, sob os auspícios de uma regra do jogo, ou seja, se o desejo do controlador é visível, se seu desejo é sustentar a instituição psicanalítica ou criar analistas, então todos os jogos de engano se tornam possíveis. O controlado poderá empregar todo seu talento em observar o desejo do Outro, já que ele é observável, e em seguida se tornar semelhante ao objeto de desejo desse analista." (Jorge, 2006, pg. 258)

Entendemos que, o fato da supervisão transcorrer fora do âmbito institucional, não é garantia de que o supervisor será então capaz de obter a tal confissão pretendida por Weil. O simples fato de que o autor opte por adotar termos como medo, vergonha, confissão, além de causar estranhamento acerca do tipo de proposta que se espera produzir com a supervisão, já é indicativo da dificuldade envolvida para o supervisionando ao tentar comunicar ao supervisor acerca de suas dúvidas e angústias na condução do tratamento, bom como sobre eventuais erros cometidos.

Diante de tal situação, primeiramente, há de se questionar até que ponto pode-se crer numa ampla transparência por parte do supervisionando para com seu supervisor, acerca do que ocorre no curso de tratamento. Não é difícil imaginar que um analista mais jovem, buscando algum tipo de reconhecimento ou confirmação junto àquele a quem admira e a quem coloca numa posição de mestre, tenha tendência de exaltar seus acertos e sucessos, deixando de comunicar eventuais erros ou problemas. Se, nas escolas de psicanálise, a supervisão enquanto requisito para obtenção do título de psicanalista pode fazer com que o psicanalista se sinta inibido e indisposto a compartilhar seus erros, não querendo colocar em risco sua aprovação como analista, por outro lado, na supervisão fora das instituições pode ocorrer que a escolha por um supervisor seja muito mais atravessada por aspectos transferenciais do supervisionando, 
escolhendo alguém com quem se identifica ou alguém que admira muito, o que pode ter efeito ainda mais agudo de inibi-lo no momento de compartilhar as situações vividas na clínica. Especialmente os casos de fracasso. Temos aí mais um importante indicativo que pode explicar porque casos de fracasso são raramente relatados na literatura. Talvez os casos mais graves sequer sejam relatados em supervisão.

Fontenele nos adverte para a importância de se considerar o que motiva a demanda de supervisão: "A demanda por supervisão, tanto quanto o seu ajuste técnico não devem, portanto, obedecer à busca de amor ou reconhecimento. Procedendo-se assim, há como resultado o engodo imaginário entre os pares analistas." (Jorge, 2006, pg. 271)

Assim, há uma dimensão transferencial a ser considerada no curso de uma supervisão e que promove uma série de impasses, sendo necessário que se evite justamente esse "engodo imaginário" indicado por Fontenele. Sobre isso, Safouan:

"Mas o que o analista supervisor deve fazer para responder a uma transferência da qual ele é objeto? Cuidar para que essa transferência permaneça uma transferência de trabalho. Concretamente falando, isso quer dizer que essa transferência é, por excelência, o domínio a que se aplica o conselho de Freud, segundo o qual não se deve tocar na transferência enquanto ela favorece o trabalho. E se ela começa a atrapalhar? Tendo o analista em supervisão um mínimo de presença acerca de seus próprios movimentos, pode-se confiar que se dará conta disso, e que, uma vez confirmada sua percepção, não deixará de analisá-la - estando, repito, preparado para fazê-lo. Caso contrário, o resultado matemático será a tendência de falar mais dele mesmo do que das análises de que se encarrega. Nesses casos, torna-se claro que a demanda de supervisão era, de fato, uma demanda de análise ou o analista em supervisão se dará conta da insuficiência de sua própria análise - e esse não será o menor favor que a supervisão poderia lhe fazer." (Jorge, 2006, pg. 283)

Neste sentido, há o debate acerca da possibilidade do próprio analista de uma pessoa atuar também como seu supervisor. Por um lado, o acúmulo de posições poderia 
trazer maiores complicações para o jogo transferencial. Por outro, o dispositivo de análise poderia propor maiores recursos para lidar com essas questões. Mas em ambos os casos há uma dimensão da relação transferencial estabelecida entre o supervisor e supervisionando e que, caso não manejada adequadamente, pode produzir uma supervisão que pouco avança nos erros ou impasses vividos no tratamento, não havendo espaço para discussão sobre erros cometidos pelo supervisionando.

Portanto, a supervisão deve estar à altura de ir para além do desejo de reconhecimento que o analista em formação apresenta, o qual envolve um ideal em relação ao supervisor e à psicanálise. Tampouco se trata da busca por um mecanismo ideal capaz de sanar todos os impasses que emergem na clínica. Pensar a transmissão da psicanálise via supervisão como um mecanismo de assegurar uma prática ideal, isolada de quaisquer riscos ou impasses, é avesso aos próprios princípios da psicanálise e aos limites de sua prática.

Slochower (2010) inclusive chega a relacionar o poder de cometer delitos na condução de tratamentos aos "ideais analíticos", reproduzidos também por supervisores, os quais exerceriam demasiada pressão sobre analista e consequentemente o analisante:

"O ideal analítico contém em si um desrespeito pela dimensão da humanidade do analista que não seja parte integrante da relação terapêutica. As infrações são virtualmente onipresentes exatamente por acharmos tão difícil reconhecer francamente e trabalhar com o conflito entre nosso egoísmo tão humano e as ainda excessivas exigências desta "profissão impossível". (...). Como analistas, devemos lutar contra a necessidade paradoxal de simultaneamente adotar o ideal analítico, sua colisão inevitável com nossa própria humanidade tão real e limitante, e a necessidade de manter uma luta constante e consciente contra o abandono desse ideal." (Slochower, 2010, p. 234).

Ou seja, o argumento de que uma supervisão que reproduz e sustenta esses ideais pode levar à reprodução de erros por parte dos psicanalistas. Ora, para a psicanálise que vai de Freud a Lacan, a função de analista está apoiada na realização de um luto pela queda de todo e qualquer ideal, de forma que o analista, tendo passado pela 
queda de seus ideais, é capaz de, na situação analítica, não conduzir o tratamento a partir de uma posição de ideal para o analisando, assim como o supervisor de forma análoga não deveria ocupar este lugar em relação a seu supervisionando. Mas isso não quer dizer que o analista que busca a supervisão também compartilhe desta condição. Se o supervisionando ainda tem com a psicanálise uma relação de opressão, ou se coloca seu supervisor numa posição de mestre idealizado, este é um sinal relevante de problemas, que deve ser levado a sério e levado à análise. Da psicanálise trata-se não de transmitir ideais, mas amainá-los, de forma a transmitir uma experiência, se não pensarmos no tratamento como uma cura-tipo, mas como a introdução ao sujeito de certa margem de liberdade (Rabinovich, 2000).

Podemos entender que tal visão da relação entre analista e analisante e do analista com a própria psicanálise enquanto situações opressivas, decorrem de uma apreensão da análise como uma relação dual, onde o trabalho do analista é encontrar uma distancia ideal entre ele o analisando, partindo da equivocada suposição de que tal relação se dá entre o $\mathrm{Eu}$ do analista ao $\mathrm{Eu}$ do analisante, recaindo numa relação essencialmente imaginária.

Acontece que, como vimos, o sujeito, enquanto efeito de linguagem, está preso, subordinando seu ser ao desejo de reconhecimento e é ai que se abrem as vias para a sugestão (Lacan, 1955/1998). É preciso que o analista reconheça que o discurso do analisante está preso ao discurso do Outro, e não na sua imagem, e é nesse sentido que ele o introduz na história da constituição das tramas do seu desejo, isto deve ser para ele o horizonte de sua intervenção. Pois aqui o analista objetiva introduzir o sujeito nas tramas das histórias onde seu desejo se constituiu. E é ai que a linguagem já constitui o campo como um terceiro, podendo retirar os sujeitos desse engodo imaginário. Contudo, é preciso estar advertido de que tal impasse pode facilmente se reproduzir também no campo da supervisão.

Se a relação intersubjetiva é concebida como uma dualidade de indivíduos, ela pode descambar para uma relação de dependência vital perpétua (Lacan, 1955/1998). Daí a necessidade de que, do lado do analista, tenha se prevenido suficientemente da imagem narcísica do Eu, bem como de suas próprias relações de identificação à figuras 
de mestria, como o supervisor ou a escola, alcançando a queda de seus ideais no curso de sua própria análise pessoal (Lacan, 1955/1998). Do lado do supervisor, é preciso estar atento para que a supervisão oferecida não estimule ou reproduza tais equívocos possivelmente apresentados pelo supervisionando.

Mas então, o que se espera de uma supervisão? Um primeiro ponto é de retomarmos aqui o que foi mencionado no item anterior, sobre a importância de que o analista em formação possa articular adequadamente o saber teórico e a prática clínica, a fim de reduzir o potencial iatrogênico de seu trabalho. A supervisão tem como uma de suas importantes funções justamente facilitar e promover a possibilidade dessa articulação entre teoria e prática: "Qual o fundamento da ideia da supervisão, desse sintoma que a supervisão representa na chamada formação do psicanalista? Estabelecer uma ponte entre a experiência clínica da psicanálise e seu estudo teórico.” (Jorge, 2006, pg. 287).

Mais especificamente sobre o modo como a supervisão pode incidir no sentido de reduzir o potencial iatrogênico, Coutinho nos indica o modo com a supervisão pode reduzir o efeito de desorientação do psicanalista ante sua divisão entre o saber da teoria e o não-saber da clínica:

"Em sua formação, o psicanalista se acha continuamente dividido entre o saber da teoria psicanalítica que lhe é oferecido pelos seminários, grupos de estudo, leituras pessoais, etc., e o não-saber por meio do qual a experiência clínica se produz. Tal divisão corre o risco, efetivamente, de desorientar o psicanalista em sua prática, fazendo muitas vezes com que o saber da teoria interfira na posição de não-saber sem a qual a clínica é impossível. A supervisão é um dispositivo que vem se inserir precisamente nesse lugar intersticial de articular o saber ao não-saber, revitalizando assim a experiência clínica e reabrindo o seu campo particular de ação. Dito de outro modo, a supervisão articula o universal da teoria ao particular da clínica e reabre o lugar da escuta, isto é, o lugar do analista, para a subjetividade em questão. (Jorge, 2006, pg. 287) 
Uma segunda contribuição da supervisão para redução das iatrogenias está no campo da imprudência. Como vimos no capítulo anterior, a imprudência está relacionada à dimensão do tempo no tratamento e também à dimensão da aposta, ou seja, de que modo as intervenções do analista devem estar em harmonia com o ritmo do tratamento e o momento vivido pelo paciente. Vimos no item anterior que, ao escutar o paciente em associação livre, o analista deve adotar a postura de atenção flutuante, sendo capaz de suspender aquilo que sabe, até mesmo seu saber teórico, privilegiando a primazia do significante. Mas então de que modo pode o analista apreender a temporalidade do tratamento e identificar o momento atravessado pela paciente e as intervenções possíveis a serem realizadas?

É certo que cada sessão tem um tempo próprio, ao qual o analista deve estar atento. Porém, há também uma dimensão do tempo do tratamento, em sua totalidade, o desenvolvimento desde a primeira sessão até o momento presente. E é aí que acreditamos que a oportunidade de construção do caso clínico, para discussão em supervisão, pode ter importante papel em conferir ao analista a possibilidade de rever o caso de uma maneira mais panorâmica: seus avanços, impasses, mudanças... obtendo subsídios para orientar suas futuras intervenções com o paciente, visando a direção do tratamento. Podemos aqui retomar o texto de Lacan sobre o Tempo Lógico e a Assunção da certeza antecipada, com a importância da supervisão enquanto tempo de compreender, antes de que se possa chegar ao momento de concluir, de realizar a aposta, intervindo junto ao paciente.

Mas mais do que essa articulação entre teoria e prática, e das questões acerca da construção dos casos, entendemos que a supervisão deva cumprir uma importante função em relação à redução de iatrogenias, ao se configurar como um espaço no qual o supervisionando pode ser advertido de certas questões transferenciais que possam estar operando como obstáculos à condução do tratamento. Neste sentido, podemos retomar os desenvolvimentos de Fontele (Jorge, 2006) quando resgata as correspondências trocadas entre Freud e Edoardo Weiss, como importante registro de um momento em que Freud é chamado a ocupar o lugar de supervisor. 
A autora discute as "supervisões" feitas por Weiss com Freud e as recomendações feitas por este. Casos em que era necessário encerrar o tratamento, questões sobre a validade ou não de um tratamento, questões sobre a posição do analista na transferência, questões acerca dos limites e possibilidades da psicanálise, direção do tratamento.

Em seus comentários, Freud destaca "que a posição analítica requer o apagamento da pessoa que ocupa o lugar de analista" e também "chama a atenção para os efeitos clínicos do poder nefasto da ambição terapêutica desmesurada". Sobre esse ponto, temos uma incidência clara de uma intervenção em supervisão que visa reduzir ou evitar o potencial iatrogênico desse furor curandis. A autora destaca esse ponto: “Assim, entre os pontos fundamentais da correspondência, encontra-se a passagem em que Freud chama a atenção para os efeitos clínicos do poder nefasto da ambição terapêutica desmesurada. Aí, observa-se como a supervisão pode servir de antídoto contra a incidência do desejo de curar a todo custo e em quaisquer circunstâncias." (Jorge, 2006, pg. 266).

Mas, de modo mais geral, os apontamentos feitos por Freud estão localizados na relação transferencial estabelecida entre Weiss e seus pacientes. E aqui nos interessa sobremaneira o papel da supervisão na redução dos potenciais iatrogênicos. Vejamos o que nos diz Fontenele (Jorge, 2006, pg. 267):

"Freud emite também alguns comentários cuja principal característica é a articulação entre a reflexão sobre a dinâmica psíquica dos analisandos de Weiss e o lugar que o analista ocupa nessa dinâmica, ou seja, trata-se não da análise puramente diagnóstica ou descritiva dos casos, e sim da oportunidade de relacionar os infortúnios do ato analítico com a dificuldade do analista em responder do lugar que ocupa na transferência, referência de que este não pode prescindir, sob pena de engendrar prejuízos ao andamento do processo analítico."

Vimos no capítulo sobre as iatrogenias como os erros por negligência transcorrem justamente quando algo do aspecto transferencial, envolvendo questões 
pessoais ou narcísicas do analista se sobrepõem aos interesses do paciente e do tratamento, sem que o analista perceba. Seja a posição que ele se coloca na transferência ou certos elementos do caso que tocam em questões pessoais suas ou ainda certas modalidades de gozo que se reproduzem com determinado paciente, o que temos é que a incidência desses aspectos pessoais do analista no tratamento representam um aumento no potencial iatrogênico do tratamento, representando maiores riscos para o paciente.

Neste sentido, a supervisão cumpre um papel de grande importância ao permitir que, no relato desses casos ao supervisor, e a partir da escuta oferecida por este, possam vir a tona tais aspectos pessoais do analista que estejam atrapalhando o trabalho, sendo possível pensar em manejos para contornar esses obstáculos, seja no trabalho com o paciente, seja no trabalho do analista em sua análise pessoal. Contudo, para que isso possa de fato operar, é preciso que o supervisor esteja alerta também para que não se reproduza o equívoco, ou seja, para que algo da transferência entre supervisor e supervisionando não produza um novo ponto cego que impeça o acesso a essas questões.

Por fim, é a partir disso que podemos resgatar o segundo elemento proposto por Jerusalinsky e Souza acerca das habilidades esperadas de um psicanalista: sua destituição narcísica. Como afirmam: "destituição narcísica constante para operar a quebra das identificações ao analista, que fechariam no analisante, a possibilidade de novas articulações simbólicas da emergência de seu próprio desejo. Uma direção que se cumpre, precisamente, na sua negativa sistemática a exercer-se.” (Safouan, 1985, pg. 8). Trata-se, então, da questões transferenciais entre paciente e analistas e que, ao serem levadas à supervisão, podem ser abordadas e tratadas.

\section{A ANÁl LSE PESSOAL}

Completando o tripé da formação do analista, temos a questão da análise pessoal. Há a ideia de que o analista é aquele que se propõe a avançar em sua própria 
análise, antes de se dedicar a conduzir a análise de seus pacientes, podendo assim lidar com seus próprios conflitos e aspectos narcísicos ou, como visto acima, a queda de seus ideais e identificações, para que não venham a interferir em seu trabalho. Uma narrativa presente - no campo da psicanálise ao menos - é a ideia de que onde erra um analista é que faltou análise, ou seja, efeito de má formação.

É ampla a discussão acerca dos objetivos ou finalidades de uma análise, bem como a possibilidade de que uma análise possa chegar a seu termo e, caso afirmativo, em que consistiria um final de análise, questão que se fez presente na obra de Freud, culminando com o texto Análise Terminável e Interminável (Freud, 1937/1996), já ao final de sua vida. Não será a proposta aqui percorrer toda a evolução deste debate no campo psicanalítico, de modo que, para uma visão geral acerca das incidências desse tema nos diversos momentos e autores da história da psicanálise, remetemos o leitor à revisão sistemática de literatura realizada por Pimentel et al. (2009).

No campo lacaniano, são frequentes também os desenvolvimentos acerca do fim de análise, a partir de diversas elaborações: travessia do fantasma, acesso ao gozoOutro, produção de um sinthome, destituição subjetiva, queda do analista enquanto ponto de identificação e suposição de saber, surgimento do desejo do analista, confrontar-se com a castração e com o impossível da relação sexual...

É sensível também a íntima relação do tema da análise pessoal com o tema da formação do analista, desde Freud, até os dias atuais. No âmbito lacaniano, o tema ganha evidência preponderante, sendo a proposta formulada por Lacan (1967/2003), em sua Proposição de 9 de outubro de 1967, sobre o dispositivo do passe, para dar conta da questão do fim de análise, uma das grandes mudanças em relação ao fim de análise. $\mathrm{O}$ dispositivo do passe foi responsável por uma série de conflitos internos, resultando em cisões que perduram até os dias atuais.

Pela relevância e amplitude do tema, não pretendemos aqui um percurso amplo por toda sua extensão. Partimos do pressuposto de que a análise pessoal tem importância fundamental para que o analista possa conduzir adequadamente as análises de seus pacientes, de modo que seus efeitos podem ser sentidos tanto para redução de 
iatrogenias por imperícia, colaborando para melhor manejo da técnica psicanalítica, como também na redução de iatrogenias por negligencia, ao permitir que o analista possa mais facilmente se desvencilhar de aspectos narcísicos que possam prejudicar o tratamento, ou ainda na redução de iatrogenias por imprudência, permitindo que o analista possa se situar melhor ante as apostas e intervenções exigidas em um tratamento psicanalítico. Assim, entendemos que o avanço na análise pessoal pode promover efeitos de redução do potencial iatrogênico que se irradiam nas três categorias iatrogênicas que adotamos nesse trabalho.

Partindo dessa premissa, optamos neste item por adotar um foco mais restrito, centrado naquilo que consideramos serem pontos mais sensíveis acerca da relação entre análise pessoal e iatrogenias. Cientes de que o tema da análise pessoal na formação do analista não se reduz exclusivamente a esse aspecto de redução de iatrogenias, mas, pelos desenvolvimentos realizados no decorrer do trabalho, entendemos que esse é o ponto para o qual mais podemos contribuir de modo mais produtivo.

Assim, uma primeira consideração que nos parece vital, e que pode ser extraída dos resultados dessa pesquisa, tem como base o que foi trabalhado no capítulo 1 , sobre a constatação de que qualquer tratamento que possui poder para produzir efeitos de cura, está também sujeita a produzir efeitos iatrogênicos, vez que do próprio fundamento que confere a uma prática seu poder, podem ser extraídos também tais efeitos iatrogênicos. Essa é uma das premissas fundamentais sustentadas nesse trabalho. Desse modo, seja o analista freudiano, winnicotiano ou lacaniano, formado pela IPA ou aprovado pelo passe no modelo lacaniano, iniciante ou experiente, todos estão sujeitos à ocorrência de efeitos iatrogênicos. Não há garantias que possam eliminar o potencial iatrogênico do tratamento, pois o próprio fundamento que confere ao tratamento seu poder é também o que produz tais riscos.

Desse modo, apesar de reconhecer a importância da análise pessoal enquanto redutora do potencial iatrogênico do tratamento, não se pode de modo algum cair no risco de crer que a análise pessoal seja capaz de produzir analistas perfeitos, ou dotados de alguma espécie de dom mágico, isentos de riscos de produção de iatrogenias, seja lá qual for o modo de formação ou de fim de análise ao qual tenha se submetido. Vale 
lembrar aqui os equívocos cometidos pelo próprio Freud na condução de alguns de seus tratamentos, como já apresentado nesse trabalho.

Desse argumento, pretendemos uma crítica a qualquer tentativa institucional que se proponha a, de algum modo, delimitar o final de análise como um modo de garantia de sucesso de todos os futuros tratamentos conduzidos por aquele analista que completou sua análise e que, a partir de então, estaria com sua formação concluída e imune à erros na condução do tratamento. Sabemos que a crítica de Lacan ao modelo de formação proposto pela IPA se insurgia justamente contra essa proposta de uma análise dita didática, compulsória e institucionalizada, que uma vez encerrada seria garantidora do sucesso da formação do analista. Lembrando aqui o argumento lacaniano de que o analista se autoriza por si mesmo (Lacan, 1967/2003).

Em todo caso, persiste ainda com Lacan a ideia de adotar essa saída da análise pessoal como caminho para produção de um analista. $\mathrm{O}$ risco aqui é de que, a partir dessa ideia, possa se concluir que uma análise pessoal que chega a seu fim teria, por si só, efeitos de produção de um analista apto à condução do tratamento, livre de erros. Mas, como já visto, seguir esse argumento seria perder de vista uma dimensão inerente à própria prática clínica e às relações de poder que o atravessam e que são potencialmente causadoras de iatrogenias.

Além disso, o abandono do dispositivo da análise didática não seria também garantia de eliminação dos atravessamentos decorrentes das relações de poder que operam nas escolas de psicanálise. As diversas cisões nas escolas lacanianas são indicador do modo como relações transferenciais e dinâmicas de poder continuaram a assombrar a formação de analistas. Ignorar esse fato seria perder de vista o próprio problema da transmissão em psicanálise que temos discutido nesse capítulo.

Temos assim que, para a análise pessoal, se repetem também muitos dos riscos já mencionados anteriormente, quando tratamento da supervisão: relação assimétrica com o analista, analista em posição de mestria, influência nociva do contexto institucional, reprodução de práticas viciadas (especialmente se considerarmos que, no âmbito das Instituições Psicanalíticas, é comum que a análise do candidato a analista 
seja conduzida por um analista da própria instituição, como a figura do analista-didata, o que torna tais problemas ainda mais contundentes), análises protocolares apenas para cumprir requisitos de formação, etc.

Há aqui também o risco de que o analista em formação venha a se identificar excessivamente com a posição de analista e com as exigências para seu reconhecimento como profissional, atrelado ao status ou reconhecimento narcísico decorrente desse título de analista (desejo de reconhecimento), resultando numa prática estéril, sem efeito de análise para o candidato. Sobre isso levantamos anteriormente os exemplos sobre o normal candidate (Gitelson, 1954 e Kupermann, 2012) e o exemplo dos candidatos homossexuais, como apresentado por Bulamah (2014).

Mais uma vez, temos que a proposta lacaniana de se afastar do dispositivo da análise didática, promovendo uma análise pessoal livre de amarras institucionais oferece avanços em reduzir os efeitos institucionais que podem atravessar a análise. Porém, não podemos crer que tal solução foi capaz de eliminar os problemas. Como já visto acima, quando tratamos do dispositivo de supervisão, há uma dimensão de relação de poder e de dinâmicas transferenciais que subsiste, ainda que de forma atenuada, mesmo quando a supervisão é conduzida fora do âmbito institucional. Acreditamos que o mesmo se aplica às análises pessoais. Mesmo a ideia de que as análises pessoais no modelo lacaniano estão livres de amarras institucionais é relativa, vez que é muito frequente que os analistas em formação conduzam suas análises com analistas da própria escola, dando margem a todo tipo de atravessamentos com a instituição.

Em todo caso, por bem ou por mal, a formação de analistas tem se perpetuado ao longo da história da psicanálise, sempre tomando como base a análise pessoal do próprio candidato. Mas dentre as diversas contribuições da literatura psicanalítica, acerca do que se produz em uma análise e o modo como isso contribui para formação de um analista, buscaremos aproximar a discussão de nosso tema de interesse: o potencial iatrogênico da psicanálise. Nesse sentido, a questão é como podemos considerar que a análise pessoal, enquanto eixo do tripé de formação, colabora ou não para redução do potencial iatrogênico? O que deve operar em uma análise pessoal, para que se produza esse efeito? 
Para isso, retomamos o que foi trazido no início desse capítulo, com as formulações de Jerusalinsky e Sousa, acerca dos três elementos centrais que configuram a posição inconsciente que define um analista, ou o que se espera que a formação do analista produza, a partir da proposta Lacaniana: "Primazia significante, destituição narcísica e des-ser: operações formantes de um sintoma: ser analista” (Safouan, 1985, pg. 8).

Desses três critérios, os dois primeiros, primazia significante e destituição narcísica, já foram tratados aqui em relação, respectivamente, ao estudo teórico e à supervisão, enquanto elementos do tripé de formação do analista e que podem atuar para redução do potencial iatrogênico do tratamento. A partir disso, entendemos que o ponto a ser desenvolvido está justamente na articulação entre os dois elementos que nos restam: análise pessoal e o des-ser do analista.

Para avançar nesse tema, seguiremos com os desenvolvimentos de Jerusalinsky e Sousa, acerca da posição inconsciente que define um analista:

"Assim, na Direção da Cura e os Princípios de seu Poder, Lacan pontualiza, na análise e crítica dos usos da transferência, a posição do analista como a de alguém em quem se estabelece a primazia do significante como o ponto capital de sua relação com Outro, e não os aspectos imaginários. Isto é: destituição narcísica constante para operar a quebra das identificações ao analista, que fechariam no analisante, a possibilidade de novas articulações simbólicas da emergência de seu próprio desejo. Uma direção que se cumpre, precisamente, na sua negativa sistemática a exercer-se. Temos, então, até aqui, dois pontos fundamentais: primazia do significante, destituição narcísica. Dois pontos que, estreitamente vinculados entre si, são também indissociáveis de um terceiro: a questão do des-ser." (Safouan, 1985, pg. 8)

Vemos então que, segundo os autores, esses três elementos são indissociáveis e se articulam para constituir o que seria a posição inconsciente do analista. Como mencionado anteriormente, é certo que a análise pessoal exerce um papel preponderante na formação do analista, de modo que seus efeitos podem se irradiar para o avanço em 
relação aos três pontos propostos pelos autores, contribuindo tanto para a questão da primazia significante, quanto para a destituição narcísica. Até mesmo porque se considerarmos o caráter radical que uma experiência de fim de análise pode produzir, o esperado é mesmo que isso traga mudanças em diversos níveis da vida desse sujeito e, no caso do psicanalista, nos diversos eixos de sua prática psicanalítica.

Ainda assim, entendemos também que a análise pessoal tem papel decisivo especialmente em relação a este terceiro ponto, o do des-ser do analista, um avanço que dificilmente poderia ser alcançado por via dos outros elementos do tripé (estudo teórico e supervisão). Dada essa íntima relação entre análise pessoal e des-ser do sujeito e considerando que os três elementos propostos pelos autores precisam estar presentes para que se possa falar em um psicanalista, entendemos aqui a análise pessoal e produção do des-ser do analista como ponto decisivo para a formação de um analista. Por sua relevância, entendemos também que esse é um ponto especialmente sensível, quanto ao potencial de redução de efeitos iatrogênicos do tratamento. Por estes motivos, será dado aqui enfoque especificamente na questão do des-ser do analista.

Seguimos então com Jerusalinsky e Sousa:

"Para nos situarmos ao respecto da operação do des-ser é necessário nos defrontarmos com outra operação: a ética. Ética, em tanto espaço que lhe outorga forma e fronteira a uma proposta, é o que articula o nada com a positividade do que se significa. Lugar de ruptura constante (que não é regra, nem moral), onde o Real faz sua obra nos limites do universo significante, forçando a fronteira e reemergendo no seio mesmo da cultura." (Safouan, 1985, pg. 08)

Desse modo, vemos reinserida aqui a questão da ética da psicanálise. Vimos no capítulo 5, com Maleval, a importância deste tema para configuração da especificidade da prática psicanalítica. Vimos também, com Dunker, a importância da ética no interior do próprio tratamento psicanalítico, intimamente ligada com o desejo do analisante e o desejo do analista. Relembrando: 
"Ocorre que, por depender intrinsecamente do sujeito para se efetivar como tal, a psicanálise não pode ser dissociada do desejo do analista e do desejo do analisante. Se um médico emprega suas técnicas sem o desejar, isso não afeta seu fazer enquanto clínico; se um analista o fizer sem desejo de analista, ele simplesmente não estará mais fazendo psicanálise, mas outra coisa qualquer." (Dunker, 2011, pg. 478)

Desse trecho, extraímos então mais um elemento de articulação: entre a ética da psicanálise, e a questão do des-ser do analista, passamos pelo tema do desejo do analista que, como vimos com Lacan, é que se espera que possa emergir ao final de uma análise. Sobre essa articulação, lembramos aqui de Lacan, em A Direção do Tratamento e os Princípios do seu Poder, quando afirma: "Cabe formular uma ética que integre as conquistas freudianas sobre o desejo: para colocar em seu vértice a questão do desejo do analista." (Lacan, 1958/1998). A questão do desejo do analista está intimamente ligada à questão da formação do analista, da análise pessoal e da transmissão da psicanálise, vez que é precisamente do trabalho em sua análise pessoal que se espera que o analista possa ter acesso a essa modalidade tão particular de desejo:

"A análise do analista precisa qualificá-lo para suportar a experiência da análise vetorizada pela transferência e seu manejo. O desejo de analista é a função lógica e ética que capacita um analista. Esse desejo ao avesso da demanda e do gozo é produzido na análise do analista.” (Fingermann, 2008)

Em suma, temos que a própria via de produção de um analista passa pela possibilidade de que, em sua análise pessoal, enquanto um dos eixos de sua formação, algo se possa produzir que inaugure essa experiência singular, com o acesso ao desejo do analista, sendo a partir desse desejo que se pode sustentar toda a possibilidade de uma posição ética do psicanalista, conferindo à psicanálise sua especificidade e permitindo que, ao conduzir um tratamento, possa também atuar na direção da cura e da produção dessa modalidade radical de experiência subjetiva com seus pacientes. 
Temos então um argumento acerca da formação do analista, sua análise pessoal e a produção do desejo do analista. Um argumento que desde cedo orientou as propostas de formação colocadas por Lacan, em especial o dispositivo do passe. Apesar das críticas ao dispositivo, até hoje, no âmbito dos analistas lacanianos, é presente esse argumento que a análise pessoal, na formação de um analista, tenha como um dos objetivos a produção do desejo do analista. Contudo, para retornar ao tema que nos interessa, cumpre inquirir de que modo isso pode ser articulado com a questão do desser do analista e com o potencial iatrogênico do tratamento. Ferreira, nos oferece uma via de avanço:

"Assim, o fim de uma análise se dirige para mais além do bemdizer e visa o bem-conviver com o sinthoma, em um percurso em que o analista irá emprestar seu corpo, não seu ser, para servir de âncora à fantasia do analisando. Para ocupar e suportar esse lugar, o analista não pode ter contas a prestar com seu ser e deve se sustentar no desejo do analista: desejo de causar desejo, para que o analisando possa nomear seu desejo.” (Jorge, 2006, pg. 140)

Ou seja, para que um analista possa avançar, no sentido de conduzir um tratamento ao seu final, trata-se de sustentar um trabalho pela via de seu corpo, enquanto ancoragem para o analisando, mas não de seu ser. Pelo contrário, trata-se aí da capacidade de se destituir de seu ser, sustentando-se então em seu desejo de analista, enquanto causa de desejo para o analisante. É nessa medida que a questão do des-ser, trazida por Jerusalinsky e Sousa deve ser situada, no sentido de que o essencial da formação de um psicanalista está em poder trabalhar com seu des-ser, ou, como coloca Ferreira, não ter contas a prestar com seu ser, sendo essa a condição de possibilidade para que um analista seja capaz de operar a inversão necessária para que a análise de seus pacientes possa chegar a termo, e para que ele, enquanto analista, possa ser destituído de sua posição de ideal para o analisando. Seguindo com Jerusalinsky e Sousa:

"É este lugar de ruptura o que a posição do analista liga no seu ato, que é analítico precisamente porque produz e reproduz a 
reemergência deste Real em Outro. O analisante, por sua vez, o implica com a responsabilidade de tal ato. Modo radical de confronto com um corte, que se pratica não a partir do heroísmo, mas da quotidianeidade. Por isso, o Inconsciente é antes ético que ôntico, e por isso a psicanálise não é uma ciência natural, mas uma prática: a prática de um ética somente possível a partir da efetivação de um des-ser." (Safouan, 1985, pg. 08)

Nesta dimensão, o ato analítico, enquanto essencial à efetivação da ética da psicanálise, só pode operar a partir de um des-ser por parte do analista, e apenas por essa via se pode esperar que a análise possa produzir no paciente essa experiência de cura, chegando assim a seu termo.

Sobre a questão da cura, retomamos mais uma vez o tripé proposto por Dunker (2011), ao situar a cura enquanto elemento essencial à prática psicanalítica, mas que, simultaneamente, irradia seus efeitos também para os campos da clínica e da terapêutica:

"Todavia, vimos que Freud tem um terceiro termo para designar a prática da psicanálise, ou seja, Kur. Sua tradução direta para cura (cure) obscurece o fato de que são dois termos distintos na origem (Kur e Heilung), ambos comprimidos pelas traduções brasileira, francesa e inglesa da mesma expressão. Falta, portanto, um termo correlato para designar os fins da experiência psicanalítica quando esta é tomada como Kur. Este termo existe em alemão, mas é de emprego raro, mas não ausente em Freud, trata-se do cuidado (Sorge). Curiosamente a expressão Sorge traduz-se tanto por cuidar de, quanto preocupar-se com e ainda por tratar de. Estamos assim diante de um termo que compreende ambas acepções anteriores, a psicoterapêutica (preocupar-se) e a clínica (tratar), mas além disso introduz uma nova ressonância semântica que ficara esquecida nas traduções, perdendo assim parte de sua autonomia: o cuidado." (Dunker, 2011, pg. 32)

Essa construção subsidia o argumento que apresentamos inicialmente, de que a análise pessoal, e consequentemente a dimensão da cura, produz efeitos que se expandem e alcançam não apenas a dimensão do des-ser do analista, mas também os 
outros elementos desse tripé (primazia significante e destituição narcísica), com potencial de redução das iatrogenias em suas três modalidades. Sobre o que se espera que a cura possa produzir ao final de um tratamento, Dunker prossegue:

"No entanto, a cura como destino para o mal-estar não pode reduzir-se ao retorno a um estado anterior. Isso é impossível, pois tratamos de alguém ao qual se acrescentou a própria experiência da cura. A cura não se constrange às ambições negativas, presente na ideia de retirada dos sintomas ou de psicoterapêutica, do desprazer. A cura não apenas faculta amar e trabalhar, mas sugere que isso possa ser feito segundo uma nova forma de estar no mundo, uma forma que convida à criação e à invenção de outras maneiras de satisfação. Quando alguém chega ao tratamento psicanalítico, tem suas próprias ambições quanto ao que a vida lhe promete e o que dela se pode esperar. Tais ambições, frequentemente tomam parte em sua própria neurose. A cura, em grande sentido, é também a cura destas ambições" (Dunker, 2011,pg. 41)

Nessa proposta de que o tratamento psicanalítico, pela via da cura, possa oferecer uma resposta ao mal-estar do sujeito, promovendo a abertura para essa nova dimensão do modo como o sujeito se situa no mundo, constatamos que esse processo envolve uma experiência radical de separação, inclusive em relação ao próprio analista, não mais situado enquanto ponto de referência a quem o saber está suposto.

Diante disso, podemos reconhecer um ponto já abordado ao longo deste trabalho, sob diversos prismas: a questão da incidência do ser do analista no tratamento enquanto produtor de iatrogenias. Mais especificamente, o argumento de que onde incide algo do ser do analista, encontramos um obstáculo à dimensão da cura e, portanto, um maior risco iatrogênico para o analisando. Vimos isso nas pesquisas das psicoterapias, acerca dos efeitos nocivos da incidência de aspectos pessoais ou narcísicos do terapeuta; no debate com Maleval, acerca do uso da sugestão no tratamento e o risco do analista ser colocado em posição de ideal para o paciente; nas críticas de Lacan ao uso da contratransferência no tratamento; com a proposta Lacaniana de que o "jogo" do tratamento psicanalítico deve chegar a seu termo, e o modo como isso deve operar; com a dimensão da cura em Dunker. Ao longo de todo o 
trabalho, um tema que insiste e mostra sua importância: o caráter prejudicial dos aspectos do ser do analista, que representam um obstáculo à direção do tratamento, sendo somente a partir do des-ser do sujeito, que pode operar numa análise a cura e o fim do tratamento.

Em relação ao tema da iatrogenia, resgatamos aqui o que foi apresentado ao final do capítulo 6, acerca de uma modalidade específica de iatrogenia por imprudência, que ocorre justamente quando o analista falha em dar termo ao jogo em curso no tratamento. Acreditamos que com a exposição acerca da formação do analista e de seu des-ser, essa modalidade de iatrogenia pode então ganhar todo seu relevo.

Vimos com Lacan a importância dada à possibilidade de que o "jogo" do tratamento psicanalítico possa chegar ao seu fim, sendo função do analista no tratamento, a partir de sua posição de quem dirige o jogo, dirigir este jogo para um fim, promovendo uma nova redistribuição das apostas feitas pelo sujeito. Essa possibilidade de colocar termo ao jogo estaria também intimamente ligada com o que foi discutido nos parágrafos acima: o desejo do analista em operação. Retomemos o que nos diz Lacan:

“(...) a astúcia do condutor do jogo, se o analista pode merecer esse nome, só pode ser por isso, por fazê-lo chegar ao fim, por desprender dessa defensiva uma forma sempre mais pura. E é isso que é o desejo do analista na operação." (Lacan, 1964-65/2006, pg. 358)

Assim, temos uma questão crucial acerca do tempo e da condução do tratamento, bem como da dimensão de aposta envolvida, ante a importância indicada por Lacan, de que o analista possa, enquanto aquele que conduz o tratamento, propiciar esta redistribuição das apostas, a partir de uma referência a este objeto $a$ e ao desejo do sujeito, sendo tal procedimento efeito do próprio desejo do analista em operação.

E então reencontramos aqui nosso argumento de que apenas a partir do desejo do analista - alcançado ao longo de sua formação enquanto analista, e no trabalho em sua análise pessoal - é que será possível ao analista promover essa redistribuição de apostas 
e esse corte que situa o analisando em sua referência a seu desejo. É dessa dimensão de corte, que convoca um fim de uma partida e uma redistribuição de apostas, que podemos situar o que é ordem do ato analítico e da ética da psicanálise.

Desse modo, se reconhecemos a importância vital de que o analista possa produzir esse momento de corte no tratamento, é forçoso estar alerta para os casos em que algo deste desejo do analista não opera, em que o ato analítico não pode incidir e em que, consequentemente, essa redistribuição de apostas não se realiza, tornando-se um obstáculo ao processo de cura, possivelmente com efeitos iatrogênicos para o paciente. Vale lembrar o que é trazido por Freud em seu texto Análise terminável e interminável (Freud, 1937/1996, pg. 236): “Em vez de indagar como se dá uma cura pela análise, se deveria perguntar quais são os obstáculos que se colocam no caminho de tal cura."

Retomamos mais uma vez, então, o exemplo trazido por Lacan, neste Seminário 12, do caso clínico relatado pela analista Pearl (Pearl, 1963). A crítica tecida por Lacan segue essa esteira, ao indicar que, mesmo após anos de trabalho com o paciente, a analista não era capaz de promover esse corte, esse fim do jogo, esse ato que convocaria o sujeito a se situar ante seu próprio desejo. O caso é ilustrativo do modo como a impossibilidade de operar esse corte gera efeitos iatrogênicos ao paciente, impedindo que o tratamento possa avançar na direção da cura. Neste sentido, o próprio Lacan chega a retomar a questão das análises intermináveis, ao se referir a esse caso a partir do conceito de contra-transferência:

"Aí está a verdadeira questão e aí aparece o que se chama mais ou
menos levianamente de contratransferência e que é, como acontece
sempre na neurose de transferência, a neurose de transferência da
qual se diz que ela é o mecanismo ativo nas análises
intermináveis." (Lacan, 1964-65/2006, pg. 155)

Mas, se sabemos que nesse caso tal momento não pode se produzir, e seguindo a orientação de Freud, para que questionemos quais são os obstáculos à cura, cabe indagar qual foi o fator que impedia que Pearl pudesse realizar esse ato? Seguindo a 
argumentação adotada nesse capítulo, entendemos que o que não opera nesse caso, é o desejo do analista. É essa a posição de Lacan ao afirmar: "O analista se evade na transferência na medida estrita em que ele não está pronto no que diz respeito ao desejo do analista." (Lacan, 1964-65/2006, pg. 155). Mas mais do que isso, e como aponta Lacan, a falha de Pearl esteve em não perceber que se colocava em uma posição de objeto de desejo para o paciente, havendo um gozo da analista ao se permitir continuar nessa posição, o que interditava a possibilidade de que a análise pudesse avançar.

Mais uma vez, reencontramos então, a questão do ser do analista. Um gozo da analista, que, a partir de seu ser, se situava enquanto objeto de desejo do paciente, inadvertida de que essa dinâmica representava o verdadeiro obstáculo à cura. Para que seu desejo de analista pudesse operar, seria necessário que a analista se ancorasse em seu des-ser, podendo situar-se então como objeto causa de desejo para esse paciente.

Vimos também com Maleval os impasses que surgem para o fim do tratamento quando um gozo do analista o leva a se colocar em posição de modelo, de ideal, de ponto de identificação para o analisando.

Temos então que quando algo da ordem de um gozo do analista intervém no tratamento, algo de seu ser, isso acaba por incidir como um obstáculo ao seu avanço. Seja o gozo narcísico de se colocar como modelo para o paciente, seja o gozo apresentado por Pearl ao se colocar como objeto de desejo, seja o gozo de ser alvo da demanda de amor do paciente... tais incidências dizem respeito ao ser do analista, e, desse modo, operam no sentido contrário de seu des-ser, de seu desejo de analista, representando um obstáculo ao tratamento.

A dimensão da cura promovida pelo tratamento psicanalítico, enquanto um processo que envolve também a destituição subjetiva do analisando, só é possível se houver a possibilidade de que possa se desprender inclusive da figura do próprio analista, não mais situado como sujeito suposto saber, como alvo de sua demanda de saber. Nesse sentido:

"Para o analisando, a destituição subjetiva implica também desalojar o analista do lugar de sujeito suposto saber e o deixar 
reduzido à condição de resto do processo analítico, quando nenhum significante vem a representá-lo (des-ser do analista)." (Pimentel et $a l, 2009)$

Contudo, como vimos, para que esse processo possa se efetivar, faz-se necessário que o analista possa operar a partir de seu desejo de analista, trabalhando com seu des-ser, abrindo assim as vias para que tal separação possa se realizar. Se, no sentido contrário, o analista se fixa em uma determinada modalidade de gozo em relação ao tratamento, isso potencialmente representará um impasse que impede que o analista seja relegado a essa condição de resto, e incidindo então na via contrária à que levaria a um fim para o tratamento. Retomando Ferreira:

"Mesmo assim, há psicanalistas que dirigem o tratamento analítico como se ele não tivesse fim, contribuindo para reforçar a ficção de que Outro tem forma (um rosto) e substância (ser), e fortalecer uma 'aliança terapêutica' entre analista e analisando que se sustenta nos vínculos forjados pelas argamassas que obturam a estrutura de falta-a-ser." (Jorge, 2006, pg. 144)

Temos aí nosso argumento de que enquanto o analista se situa numa posição de Outro, mas ancorado em uma dimensão de forma e substância, ou seja, de seu ser, o que se produz como efeito é uma aliança terapêutica contrária à dimensão da cura e a possibilidade de um fim do tratamento.

Sobre esse ponto, do ser do sujeito enquanto obstáculo à cura, acreditamos que cabe ainda destacar um ponto que julgamos relevante. Trata-se da advertência acerca de uma modalidade de gozo do analista, mais sutil, que pode intervir no tratamento e muitas vezes é responsável por análises intermináveis, que não são capazes de alcançar o objetivo de cura, não possibilitando essa "redivisão das apostas", sugerida por Lacan como final do jogo.

Referimo-nos aqui aos casos em que há para o analista um gozo no próprio exercício de sua escuta analítica, ou seja, quando o trabalho de deciframento do inconsciente do paciente vira um fim em si mesmo, alimentando um gozo advindo da 
produção crescente de mais saber sobre o inconsciente, gozo para o analista, mas também para o analisando, num pacto que tem como efeito perpetuar indefinidamente o tratamento, sem maiores avanços para o paciente. Neste sentido, Laurent questiona: "Como sustentar a ética da psicanálise, se o analista goza com sua escuta, porque "se identifica com o 'goza-ouço [jouis, goza, e j'ouis, eu ouço] do supereu?" (Laurent, 1995, pg. 38). Ferreira descreve em maiores detalhes esse tipo de pacto de gozo estabelecido entre analista e paciente e que resultaria numa análise interminável:

"Como um sujeito desejante pode advir, se o analisando é levado pela analista à posição de objeto de gozo do Outro: "Eu falo, você escuta, nós gozamos..."? Estamos aqui diante de um projeto de análise sem fim, em que o dispositivo analítico, posto a serviço do gozo do analista, inviabiliza a nomeação do desejo e a conquista do bem-dizer, sem a qual não é possível conviver com o sinthoma. Dito de outro modo, estamos diante de um tratamento que se dirige, exclusivamente, rumo à decifração do saber inconsciente. É lógico que alguns efeitos se produzem, à medida que o gozo retirado dos sintomas é substituído pelo gozo da decifração. O preço a ser pago é uma análise interminável, já que o inconsciente não para de trabalhar e de produzir mensagens cifradas." (Jorge, 2006, pg. 144)

Temos assim uma modalidade de gozo do analista a partir do próprio trabalho de escuta do paciente. Um gozo mais sutil, por vezes mais difícil de ser identificado, mas que certamente pode resultar em efeitos iatrogênicos. Retomando a questão da imprudência e do tempo no tratamento psicanalítico, isso envolve também a possibilidade de alcançar o fim do tratamento, colocar um termo a esse tempo de análise, convocando o sujeito a se reposicionar diante de seu desejo. Em resumo, como afirma Ferreira:

"Seja qual for a resposta, é preciso que o analista se sustente na ética da psicanálise (desejo do analista) e não usufrua do gozo de sua escuta, nem do amor que lhe é dirigido pela força arrebatadora da transferência." (Jorge, 2006, pg. 150) 
Para concluir esse debate, recorremos à Lacan (1963-64/1996), em seu Seminário 11, quando se refere ao desejo do analista, enquanto desejo de obter a diferença absoluta:

"O desejo do analista não é um desejo puro. É um desejo de obter a diferença absoluta, aquela que intervém quando, confrontado com o significante primordial, o sujeito vem, pela primeira vez, à posição de se assujeitar a ele. Só aí pode surgir a significação de um amor sem limite, porque fora dos limites da lei, somente onde lê pode viver." (Lacan, 1963-64/1996, pág. 260.)

Não se pode pretender alcançar esta radicalidade de uma diferença absoluta, se não for possível que haja também uma separação decisiva entre analista e analisando, não mais capturados num engodo imaginário, tão pouco em uma aliança terapêutica ou um pacto de gozo. Trata-se aqui de que o analista possa sustentar esse desejo do analista até suas últimas consequências.

Lembrando de Lacan, para considerar que talvez o erro iatrogênico passível de responsabilização ocorre quando o analista cede de seu desejo: "Proponho que a única coisa da qual se possa ser culpado, pelo menos na perspectiva analítica, é de ter cedido de seu desejo." (Lacan, 1959-60/1997, Pag. 382.)

Mas diante de tudo isso, o que esperar então de uma análise pessoal na formação de um analista, a fim de que se possa reduzir o potencial iatrogênico dos tratamentos?

Buscamos sustentar que faz-se necessário que essa análise possa produzir nesse analista algo dessa experiência radical de diferença absoluta, sendo esta a via para que possa também operar a partir de seu des-ser, possibilitando que possa também conduzir seus analisandos à essa experiência. Neste sentido, acompanhamos Fingermann (2008):

"O que se espera da análise do analista? Espera-se que ela produza os tais desejo, ato, função, discurso dos quais depende a prática consequente da psicanálise e seu futuro. (...) A análise do analista precisa, portanto, produzir o operador "desejo de analista" para capacitá-lo a dirigir os tratamentos analíticos do começo ao fim da transferência." 
Cabe aqui uma breve consideração sobre o final de análise e três conclusões equivocadas que queremos evitar.

Em primeiro lugar, não esperamos com essas construções chegar a uma conclusão que, de modo equivocado, recaia no ponto de partida, ou seja, no equívoco de crer que uma análise pessoal concluída ou suficientemente avançada seja uma garantia de uma prática livre de riscos. Afirmamos que o que se espera de uma análise, na formação do analista, é que possa lhe oferecer o acesso a esse desejo do analista e a uma experiência de des-ser que possa subsidiar sua prática clínica. Isso se estabelece como condição de possibilidade para que possa reproduzir esses efeitos com seus analisandos, mas de modo algum há garantia de que isso sempre será possível ou bem sucedido. Ou seja, aceitar que um analista chegue ao fim de sua análise e possa vir a tona seu desejo de analista, não significa dizer que, uma vez alcançado tal objetivo, o analista estaria livre de riscos na condução do tratamento. Como visto, a própria atividade psicanalítica tem em seus fundamentos uma dinâmica de poder responsável pelo sucesso do tratamento, mas ao mesmo tempo, potencial promotora de efeitos iatrogênicos.

Em segundo lugar, tão pouco acreditamos que alcançar esse objetivo, de produção do desejo do analista em sua análise pessoal, significaria para o analista um fim definitivo de seu processo de análise, no sentido de que jamais precisaria retornar para uma nova análise. Encerra-se uma análise, o que não significa a produção de um ser acabado, perfeito, para o qual jamais haveria necessidade de algum tipo de trabalho analítico futuro.

Neste sentido, acompanhamos Freud quando, em Análise Terminável e Interminável (1937/1996), menciona algo que seria da ordem de um efeito iatrogênico do tratamento que incide sobre o próprio analista, utilizando isso para indicar a necessidade de que, com certa periodicidade, a análise do analista fosse também sempre retomada:

"Não seria de surpreender que o efeito de uma preocupação constante com todo o material reprimido que luta por liberdade na mente humana despertasse também no analista as exigências instintuais que de outra maneira ele é capaz de manter suprimidas. 
Também esses são 'perigos da análise', embora ameacem não o parceiro passivo, mas o parceiro ativo da situação analítica, e não deveríamos negligenciar enfrentá-los. Não pode haver dúvida sobre o modo como isso deve ser feito. Todo analista deveria periodicamente - com intervalos de aproximadamente cinco anos submeter-se mais uma vez à análise, sem se sentir envergonhado por tomar essa medida. Isso significaria, portanto, que não seria apenas a análise terapêutica dos pacientes, mas sua própria análise que se transformaria de tarefa terminável em interminável." (Freud, 1937/1996, pg. 266)

Ou seja, que a análise do analista possa ser retomada, tantas vezes quantas forem necessárias, ao longo de sua vida e de sua prática psicanalítica, independentemente do grau de experiência ou reconhecimento que já tenha alcançado.

Por fim, o terceiro ponto, não queremos que tal lógica argumentativa seja usada para recair em tentativas de controle ou cerceamento da prática da psicanálise, retornando à vícios institucionais como, por exemplo, a ideia de que somente o analista que houvesse cumprido algum tipo de requisito, no sentido de ter completado sua análise, poderia estar autorizado ao exercício da psicanálise. Já repassamos por diversas vezes ao longo desse capítulo os riscos envolvidos em tal tipo de tentativas de controle da prática psicanalítica, potencialmente agravadores do potencial iatrogênico do tratamento. Mais do que os riscos envolvidos, insistimos na própria impossibilidade de que se possa controlar a prática psicanalítica, no sentido de eximi-la de riscos ou apostas que, na verdade, são inerentes à sua própria essência.

A preocupação aqui é de fugir de uma concepção de fim de análise que seja utilizada para promover cisões ou hierarquias, entre os qualificados ou os não qualificados, os analisados ou não analisados, os que podem ou não exercer a psicanálise. Vimos acima que não se trata de uma questão de fim de análise, no sentido de produção de um ser perfeito que não mais precisará recorrer à análise. Pelo contrário, mais do que uma questão de fim de análise, buscamos aqui pensar nas finalidades da análise, ou seja, que experiência se espera que uma análise possa produzir e, no caso de um analista, de que modo tais experiências de sua análise pessoal podem subsidiar sua 
prática clínica. Acreditamos que tal processo de acesso a essas experiências transcorre de modo gradativo ao longo de sua análise, estabelecendo uma relação recíproca com sua prática clínica, de modo que se subsidiem mutuamente. Julgamos improvável que um analista possa conduzir uma análise para além do que avançou em sua própria análise. Contudo, não se pode também defender que faça todo o percurso de sua análise pessoal, antes de poder iniciar sua prática clínica. Aqui acompanhamos mais uma vez Freud (1937/1996, pg. 265):

\begin{abstract}
"Evidentemente, não podemos exigir que o analista em perspectiva seja um ser perfeito antes que assuma a análise, ou em outras palavras, que somente pessoas de alta e rara perfeição ingressem na profissão. Mas onde e como pode o pobre infeliz adquirir as qualificações ideais de que necessitará em sua profissão? A resposta é: na análise de si mesmo, com a qual começa sua preparação para a futura atividade. Por razões práticas, essa análise só pode ser breve e incompleta. Seu objetivo principal é capacitar o professor a fazer um juízo sobre se o candidato pode ser aceito para formação posterior. Essa análise terá realizado seu intuito se fornecer àquele que aprende uma convicção firme da existência do inconsciente, se o capacitar, quando o material reprimido surge, a perceber em si mesmo coisas que de outra maneira seriam inacreditáveis para ele, e se lhe mostra um primeiro exemplo da técnica que provou ser a única eficaz no trabalho analítico."
\end{abstract}

Ou seja, não se trata, quanto à formação do analista, de restringir o acesso da profissão a "pessoas de alta e rara perfeição", ou analistas que tenham passado por tal ou qual processo de titulação ou verificação, mas sim de assegurar que a análise pessoal desses jovens analistas possa transcorrer da melhor maneira possível, advertida de todos os riscos que foram discutidos ao longo desse capítulo, possibilitando o avanço em sua análise e em sua prática clínica, sempre no sentido da direção do tratamento, de uma redistribuição cada vez mais pura das apostas, situando-se e responsabilizando-se por seu desejo.

Sobre isso, Freud (1937/1996), nos alerta para o que poderíamos considerar um efeito iatrogênico das análises pessoais de formação, e que acreditamos ocorra com 
bastante frequência. Se reconhecemos que um analista só conduz seu paciente até onde avançou em sua própria análise, podemos supor que esse tipo de iatrogenia, causado por analistas que não avançaram suficientemente em sua análise, tendem a se reproduzir e propagar de geração para geração. Trata-se dos casos em que a análise conduzida, em vez de promover avanços na direção da cura, atuam para reforçar mecanismos defensivos e repressivos por parte do jovem analista:

"Parece que certo número de analistas aprende a fazer uso de mecanismos defensivos que lhes permitem desviar de si próprios as implicações e as exigências da análise (provavelmente dirigindo-as para outras pessoas), de maneira que eles próprios permanecem como são e podem afastar-se da influência crítica e corretiva da análise. Tal acontecimento poderia justificar as palavras do escritor que nos adverte que, quando se dota um homem de poder, é difícil para ele não utilizá-lo mal.” (Freud, 1937/1996, pg. 265)

Assim, se no percurso de formação, um jovem analista se submete a uma análise, com alguém que não avançou suficientemente em sua própria análise, o risco iatrogênico é de que se reproduza essa dinâmica, de um tratamento que não pode avançar no sentido de produzir o desejo do analista. 


\section{CONSIDERAÇÕES FINAIS}

Iniciamos nosso trabalho com o objetivo de conduzir uma investigação acerca do potencial iatrogênico da psicanálise. De partida, constatou-se que se tratava de tema pouco explorado na literatura psicanalítica, chegando-se a percepção de que, antes de que se pudesse investigar os eventuais efeitos iatrogênicos de um tratamento psicanalítico, seria necessário, primeiramente, investigar se existe a possibilidade de que um tratamento psicanalítico possa produzir iatrogenias.

Demos então um passo atrás, percorrendo uma via de investigação por outros campos de saber, que não a psicanálise, a fim de identificar elementos pertinentes ao tema da iatrogenia, que pudessem subsidiar a discussão sobre o tema no campo da psicanálise.

No capítulo 1, evocamos, do campo da Medicina, o trabalho de Hipócrates e o juramento Hipocrático, que colocam como princípio fundamental da prática médica que, antes de mais nada, não se causa mal ao paciente. Seguimos nosso caminho com o embate entre Eysenck e Bergin, acerca da eficácia dos tratamentos psicanalíticos e das psicoterapias em geral. A partir desse debate, Bergin foi capaz de constatar não apenas que o tratamento psicanalítico produzir efeitos, sendo eficaz para o tratamento de pacientes com doenças mentais, mas também que, por vezes, o mesmo tratamento era capaz de produzir efeitos prejudiciais ao paciente, agravando ou piorando o quadro clínico do paciente, hipótese para a qual cunhou o termo deterioration effect.

Temos então um ponto de sustentação, confirmando a hipótese de que o tratamento psicanalítico possa também produzir efeitos iatrogênicos. Mas Bergin nos oferece poucas pistas acerca das causas desses efeitos, os modos como eles incidem em um tratamento ou, ainda, quais seriam as vias para evitar ou reduzir que se produzam essa iatrogenias. Questões que, como vimos, são pouco exploradas na literatura psicanalítica. 
Apresenta-se a questão sobre quais os obstáculos que impedem o avanço das pesquisas sobre o tema e que justificam essa carência de literatura sobre o tema. Recorremos então a pesquisas oriundas de outros campos do saber, como Medicina, Farmacologia e psicoterapias, a fim de responder a essa questão.

No capítulo 2 apresentamos então quais seriam as principais dificuldades metodológicas indicadas na literatura acerca da investigação sobre efeitos iatrogênicos. Vimos que nos campos da Farmacêutica e até mesmo da Medicina, há uma grande preocupação com pesquisas sobre potenciais iatrogênicos, sendo que os medicamentos ou tratamentos, antes de serem aprovados, passam por diversos procedimentos de teste, visando verificar sua segurança. Contudo, tais procedimentos só são possíveis pois nesses campos há maior facilidade em identificar os efeitos iatrogênicos produzidos, bem como em avaliar as correlações entre o tratamento oferecido e o efeito iatrogênico causado. Assim, pode-se, por exemplo, alterar a dose de um medicamento, a fim de evitar uma reação adversa, ou substituir um procedimento cirúrgico mais invasivo por outro menos invasivo mas de eficácia equivalente.

No campo da saúde mental, essas correlações não são tão evidentes, de modo que o desafio de identificar e prevenir efeitos iatrogênicos é muito maior. Há grande dificuldade em identificar o que de fato poderia ser considerado um efeito iatrogênico, bem como em conseguir articular algum tipo de relação de causa e efeito entre o fenômeno observado e o tratamento utilizado. Além disso, o papel dos profissionais na investigação dos efeitos iatrogênicos também se apresenta como um obstáculo. Seja pela crença equivocada de que o tratamento não pode causar prejuízos, seja pelo medo de serem sancionados ou malvistos, caso compartilhem experiências de erro ou fracasso, ou ainda pela própria incapacidade em identificar os efeitos iatrogênicos produzidos, o que a literatura mostra é que é raro que os profissionais tragam ao debate com os colegas de profissão questões acerca dos efeitos iatrogênicos produzidos, o que, por sua vez, retarda ainda mais os avanços das pesquisas sobre o tema.

Destes resultados, dois pontos foram destacados para continuidade do trabalho. O primeiro ponto é o argumento de que para que se possa avançar na investigação sobre o tema da iatrogenia, faz-se necessário definir algum tipo de terminologia adequada, 
operadores teóricos, que possibilitem identificar, classificar e analisar os possíveis efeitos iatrogênicos decorrentes do tratamento. O segundo ponto de interesse é o destaque para a importância de que para redução dos riscos iatrogênicos dos tratamentos é necessário que os profissionais ampliem os debates acerca desse tema, estando atentos para investigar e discutir os eventuais efeitos iatrogênicos que os tratamentos oferecidos venham a causar.

No capítulo subsequente, ainda com recurso a outros campos de saber, como Direito, Medicina e Sociologia, visamos avançar nesse primeiro ponto, de definir uma terminologia aplicável ao campo das iatrogenias. Destacamos a importância de poder distinguir iatrogenias institucionais de iatrogenias produzidas no interior do dispositivo clínico. Estabelecemos também uma distinção entre casos em que o próprio tratamento utilizado é, em si, iatrogênico, e casos em que a iatrogenia decorre de uma atuação inadequada do profissional. Para esse último campo, das iatrogenias decorrentes de uma atuação indevida do profissional, diferenciamos entre casos em que o profissional deliberadamente ou dolosamente produz uma iatrogenia, e casos em que o profissional acidentalmente ou culposamente ocasiona uma iatrogenia no curso do tratamento.

A partir dessas distinções, optamos por centrar nossa pesquisa neste último grupo, das iatrogenias causadas no interior do dispositivo clínico, a partir de uma atuação culposa do profissional. Para esse grupo, recolhemos então, a partir da literatura, três categorias que permitem diferenciar e classificar diferentes modalidades de iatrogenias, definidas a partir de um critério que considera as causas que o produziram a iatrogenia. Temos então as iatrogenias por imperícia, para os casos em que há uma falha do profissional no uso da técnica envolvida em sua prática; as iatrogenias por negligencia, para os casos em que houve algum tipo de descaso ou falta de cuidado na condução do tratamento; e, por fim, as iatrogenias por imprudência, para casos em que o profissional age de maneira apressada, sem a devida cautela inerente à condução do tratamento.

Já no capítulo 4, apresentamos os resultados do levantamento bibliográfico acerca do tema da iatrogenia no campo das psicoterapias. Uma primeira parte dos resultados apresentados, abordava quais seriam os possíveis efeitos iatrogênicos que um 
tratamento pode produzir. Dentre os principais efeitos iatrogênicos destacados pela literatura, destacamos os casos em que o a relação estabelecida entre paciente e terapeuta por algum motivo se transforma, deixando de operar enquanto facilitador do tratamento e adquirindo então um caráter de dependência do paciente ao terapeuta, passando a representar um obstáculo ao avanço do tratamento. Casos em que o paciente se aliena na pessoa do terapeuta, colocando-o uma posição de ideal, e assim deixando de se responsabilizar por seu próprio sofrimento. Temos então uma primeira notícia importante de como a influência do terapeuta sobre o paciente pode ser produtora de efeitos iatrogênicos.

Numa segunda parte do capítulo foram apresentados os resultados que tratam de fatores causadores de iatrogenias. A apresentação dos resultados foi dividida em categorias: aspectos do terapeuta; aspectos do paciente; aspectos da relação estabelecida entre terapeuta e paciente; aspectos incontornáveis da situação social do paciente. Destes resultados, destacamos a importância conferida pela literatura à relação entre paciente e terapeuta que, ao mesmo tempo em que se mostra essencial para o sucesso do tratamento, se mostra também como uma das principais fontes de produção de efeitos iatrogênicos. Aqui, podemos relembrar de Bergin, com a constatação de que o tratamento que é eficaz pode também produzir iatrogenias. Recolhemos então mais um elemento útil para nosso avanço na investigação sobre o tema, a partir dessa importância da relação entre paciente e terapeuta, tanto como um fundamento do tratamento, que lhe confere sua eficácia, quanto como potencial produtora de iatrogenias.

Munidos desses elementos, adentramos então, no Capítulo 5, a investigação do tema da iatrogenia no campo da psicanálise. Para isso, tomamos como fio condutor a importância da relação entre paciente e terapeuta ou, para a psicanálise, a relação transferencial estabelecida entre analista e paciente, cientes de que a relação transferencial constitui o próprio fundamento dessa prática singular proposta por Freud enquanto dispositivo de cura. Mas poderia ela estar também na base da produção de efeitos iatrogênicos no tratamento?

Avançamos então com as elaborações trazidas por Maleval, a respeito dos riscos iatrogênicos que a influência do analista sobre o paciente podem produzir. Maleval 
retoma as três grandes epidemias de patologias iatrogênicas ocorridas nos EUA na década de 80, para discutir o modo como o uso equivocado da influência por parte dos terapeutas propiciou a ocorrência de tais efeitos iatrogênicos.

Maleval nos indica que o específico da prática psicanalítica estaria nessa posição ética do psicanalista na condução do tratamento, enquanto aquele que se recusa ao exercício de um poder, entendendo que o próprio paciente é o único que pode dizer de seu sofrimento, e convocando-o a se implicar naquilo de que se queixa. Diante disso, sustenta que a produção de efeitos iatrogênicos está diretamente relacionada com um exercício de poder por parte do terapeuta e, a partir disso, sustenta que a psicanálise se difere das psicoterapias justamente por sua recusa ao exercício do poder, o que, consequentemente, eliminaria os riscos de produção de iatrogenias.

Encontramos com Maleval um eixo essencial para que se possa pensar a produção de efeitos iatrogênicos: os usos feitos do poder no curso de um tratamento. Contudo, se a aposta é de que os efeitos iatrogênicos estão relacionados aos usos feitos do poder, resta então inquirir de que modo a questão do poder se apresenta no tratamento psicanalítico.

Seguimos então por um percurso pela obra de Freud, rastreando o tema da sugestão e da influência, desde seu início, com seus trabalhos com Charcot e o uso da hipnose, passando pela montagem do dispositivo clínico, com a regra da associação livre e o estabelecimento da transferência, depois o trabalho de análise das resistências do paciente, para, enfim, chegar à questão da própria interpretação da transferência. Percebe-se, então, que não se trata, no dispositivo psicanalítico, de uma relação que se exime ou que exclui a incidência do poder na relação transferencial, mas, pelo contrário, da própria novidade trazida por Freud que reside na possibilidade de que até mesmo esses efeitos transferenciais e incidências do poder possam ser objeto de trabalho no curso da análise.

Aqui, nos afastamos de Maleval, e resgatamos o trabalho de Lima que ao trazer um aporte da teoria Foucaultiana para a questão do poder na psicanálise, nos indica justamente a impossibilidade de pensar uma prática clínica livre de questões de poder. 
As relações de poder estão presentes e são inerentes às relações humanas e a psicanálise não se situa fora disso. Neste ponto podemos articular nosso argumento anterior, de que a relação transferencial ao mesmo tempo em que confere ao tratamento sua eficácia, pode ser também produtora de iatrogenias. Em resumo: é a partir da própria relação entre analista e analisando, e a partir das dinâmicas de poder que atravessam essa relação, que podemos situar tanto o potencial do tratamento de promover a cura, quanto o risco de que possa produzir efeitos iatrogênicos.

Diante disso, em vez de adotar uma postura que considera a psicanálise como prática que, de algum modo, conseguiu solucionar os impasses das dinâmicas de poder e que, desse modo, se diferencia das outras práticas de cura, adotamos a posição de que é necessário que os psicanalistas possam considerar as dinâmicas de poder que atravessam sua prática e os modos como operam, seja na direção da cura, seja na produção de efeitos iatrogênicos.

Aqui retomamos a máxima de Lacan em $A$ direção do tratamento e os princípios de seu poder: "Pretendemos demonstrar como a impotência em sustentar autenticamente uma práxis reduz-se, como é comum na história dos homens, ao exercício de um poder" (Lacan, 1958/1998). É certo, então, que não se deve reduzir a prática psicanalítica apenas ao exercício de um poder, mas isso não também excluir completamente a questão do poder, negando-a ou tomando-a por resolvida. Lacan mesmo nos alerta para esse ponto, ao destacar quais os Princípios do Poder, na clínica psicanalítica.

É nessa esteira que situamos a responsabilidade do analista ao assumir um tratamento, responsabilidade situada justamente na possibilidade de reconhecer essas dinâmicas de poder para, a partir daí, poder operar no sentido da direção do tratamento e, consequentemente, convocando o sujeito a posicionar-se diante de seu desejo. Sendo essa a via pela qual o analista pode operar também para redução do potencial iatrogênico do tratamento.

Mas, mais uma vez, não se trata aqui de ceder ou se conformar com uma posição que reduz a questão da iatrogenia no tratamento psicanalítico a um mero alerta sobre a importância da ética do psicanalista na condução do tratamento, ou, como afirma Lacan: 
“Isto não é para nos enganarmos juntos com uma advertência sobre a responsabilidade na prática." (Lacan, 1964-65/2006, pg. 417). Se reconhecemos a importância das dinâmicas de poder no curso do tratamento, enquanto produtoras de iatrogenias, é preciso avançar para investigar de que modo essas dinâmicas operam no curso de um tratamento, não bastando que a discussão seja reduzida à dimensão da ética da psicanálise.

Seguimos então avançando, desta vez com Dunker, com sua proposta de reconstrução da estrutura e constituição da clínica psicanalítica. Um dos argumentos centrais sustentados pelo autor é de que a prática psicanalítica se insere numa genealogia, tendo sua origem relacionada às diversas práticas de cura, psicoterapias, tratamentos, que se articularam para possibilitar a constituição desta práxis tão singular que é a clínica psicanalítica.

Nesta práxis psicanalítica - continuando com Dunker - por mais que se reconheça a dimensão e importância da ética e da cura enquanto vitais para caracterizar a especificidade da prática psicanalítica, é necessário que essa dimensão possa também se articular ainda com duas outras dimensões que compõem a prática psicanalítica: a dimensão da clínica e a dimensão da terapêutica. Temos então uma proposta da prática psicanalítica enquanto prática heterogênea, na qual se articulam essas três dimensões distintas, porém relacionadas: a dimensão da clínica, a dimensão da terapêutica e a dimensão da cura. Concluindo, com Dunker, reduzir a prática psicanalítica a apenas uma ou duas dessas dimensões seria perder a própria especificidade da prática psicanalítica.

Tendo isso no horizonte, avançamos para o capítulo 6 com esse objetivo de uma investigação acerca do potencial iatrogênico da psicanálise que pudesse considerar os aspectos envolvidos na própria dinâmica dessa prática. Para essa tarefa, escolhemos trabalhar com os desenvolvimentos trazidos por Lacan em seu Seminário 12, em que aborda centralmente a questão de como se configura a práxis psicanalítica, qual o estatuto do saber do psicanalista e quais as habilidades ou capacidades que se poderia esperar de um psicanalista, para condução de sua prática. 
Dentre outros desenvolvimentos tecidos a partir desse Seminário 12, destacamos especialmente a proposta feita por Lacan de formalização da prática psicanalítica como algo semelhante a um jogo. Um jogo composto por três elementos fundamentais que compõem o jogo (o sujeito, o saber e o sexo), que se organizam numa relação de dominância circular, sendo a partir dessa relação que o sujeito se reengendra, sempre em uma relação com o saber e o sexo. Desse modo, o dispositivo psicanalítico pode ser articulado como um jogo envolvendo esses três elementos: inicialmente, dá-se início ao jogo a partir da relação do sujeito com seu saber e, mais especificamente, a suposição de saber colocada no analista. A partir do estabelecimento da transferência e com as incidências do terceiro elemento, o sexo, enquanto aquele que promove um furo no saber, abre-se o acesso para a dimensão do sujeito e seu inconsciente. Se desenvolve então uma dinâmica de lances sucessivos, entre analista e analisando, a partir desses três elementos, sendo responsabilidade do analista dirigir o jogo, conduzi-lo visando um fim, um momento decisivo em que o analista intervém de modo propiciar a produção, para um sujeito, de um novo arranjo entre seus três polos, uma nova organização mais pura que, a partir do objeto $a$, permite que o sujeito se situe ante seu desejo.

Mais uma vez com Dunker, avançamos sobre essa proposta de formalização trazida por Lacan, para esmiuçar de que modo esse jogo transcorre na dinâmica da clínica psicanalítica. Vimos como na relação entre sujeito e saber está o início do tratamento, vez que o sujeito supõe ao analista um saber e passa a falar, estabelecendo assim a relação transferencial. Depois, entre saber e sexo, as regras do jogo psicanalítico, as intervenções, interpretações ou manejos feito pelo analista no sentido de promover no analisando algum tipo de divisão ou furo no saber que possibilite o avanço do tratamento. Por fim, entre sexo e sujeito, a dinâmica de apostas, os cortes ou o ato analítico, que convoca o sujeito a se situar diante desse furo no saber, desse impossível da relação sexual.

Tomando esta formalização do dispositivo psicanalítico como base, partimos então para buscar uma articulação com os efeitos iatrogênicos do tratamento. Recuperando as três categorias propostas anteriormente (iatrogenia por imperícia, iatrogenia por negligencia e iatrogenia por imprudência), buscamos localizar quais os 
momentos ou operações do dispositivo psicanalítico que representam maior potencial de ocorrência de efeitos iatrogênicos.

Sustentamos então que as iatrogenias por imperícia podem ser localizadas principalmente na relação entre sujeito e saber, ou seja, na relação transferencial, vez que aí situamos o fundamento da técnica psicanalítica. Ou seja, quando algo do manejo da técnica não é adequadamente realizado pelo analista, com prejuízos ao estabelecimento da relação transferencial, podemos esperar que haja um maior potencial para ocorrência de efeitos iatrogênicos, como efeito da imperícia do analista na condução do tratamento.

Em seguida, situamos a questão da negligencia na dimensão entre o saber e o sexo. Se vimos que, entre sujeito e saber, temos a montagem da transferência, enquanto operação na qual o analisando situa o analista em posição de suposição de saber, aqui, entre saber e sexo, esperamos que algo da atuação do analista possa atuar no sentido de promover um furo nessa dinâmica, ou seja, uma suspensão, ou furo no saber, que permita o avanço na direção do tratamento. Mas, para que isso possa ocorrer, é vital que o analista esteja advertido para que questões pessoais suas, como aspectos narcísicos ou modalidades de gozo, não se coloquem como obstáculo a esse processo. É preciso que o analista possa sair de uma posição de ideal, de modelo de identificação para o paciente, indicando a via para algo além dessa relação entre sujeito e saber. Trata-se, então, de não permitir que seus aspectos pessoais se sobreponham aos interesses do paciente e à direção do tratamento. Por esse motivo, quando algo desse processo falha, entendemos que há um aumento no potencial iatrogênico, por conta de uma postura negligente por parte do analista.

Por fim, entre o sexo e o sujeito, localizamos a dimensão das iatrogenias causadas por imprudência. Vimos que nesta relação entre sexo e sujeito Lacan localiza a possibilidade de uma abertura para algo da ordem de uma nova aposta, ou melhor, uma redistribuição das apostas, com uma nova modalidade de relação entre os três elementos do jogo, sempre visando uma relação mais pura, mais alinhada com algo da ordem do desejo do sujeito. Temos então, entre sexo e sujeito, o que é da ordem da aposta no tratamento analítico. Tais apostas se produzem também a partir da ação do analista, ou 
melhor dizendo, do ato do analista, que convoca o sujeito a essa redistribuição das apostas. Mas tais intervenções se articulam também com uma dimensão de temporalidade do tratamento. Tempo aqui tomado enquanto tempo lógico, no sentido de que há um processo envolvido, uma sucessão de etapas que vão culminar neste momento de aposta. Uma intervenção intempestiva, feita de modo apressado ou, inversamente, que chegue tardiamente, pode se mostrar completamente ineficaz ou, pior, resultar em prejuízos para o tratamento e, consequentemente, para o sujeito. Consideramos aqui também os casos em que esse momento sequer chega a se produzir em um tratamento. Pela relação com a questão do tempo no curso de um tratamento, e também por seu caráter de aposta, entendemos que aqui temos um momento particularmente sensível à ocorrência de iatrogenias resultantes de uma imprudência por parte do analista.

Com essas articulações, acreditamos ter sido capazes de produzir uma primeira via de leitura para o tema dos efeitos iatrogênicos no tratamento psicanalítico, estabelecendo fundamentos para que a pesquisa sobre o tema possa se desenvolver futuramente.

No entanto, nos restava ainda mais um ponto sobre o qual avançar: de que modo os resultados alcançados nesta pesquisa podem colaborar para uma redução do potencial iatrogênico da psicanálise? Essa é a questão central que motivou esta pesquisa é também onde acreditamos poder contribuir de modo mais decisivo. Pela complexidade do tema, não esperamos produzir aqui soluções definitivas que possam sanar todas as questões pertinentes ao tema. O que desejamos é que os desenvolvimentos aqui apresentados possam abrir questões e colocar novos desafios que possam convocar os analistas a repensarem os efeitos de sua prática, com uma atenção renovada acerca da possibilidade de que venham a produzir efeitos iatrogênicos nos tratamentos que conduzem.

Com esse intuito, optamos, no Capítulo 7, por discutir a questão da formação do psicanalista, sob o prisma do potencial iatrogênico da psicanálise. Para isso, nos propomos a efetuar uma articulação entre dois tripés de nosso interesse. De um lado, o tripé das categorias de iatrogenias culposas que desenvolvemos ao longo dessa 
pesquisa: iatrogenia por imperícia, iatrogenia por negligência, e iatrogenia por imprudência. De outro lado, o tripé da formação do analista: estudo teórico, supervisão e análise pessoal.

Para conduzir essa articulação, recorremos ainda há dois outros tripés que nos são caros. O primeiro, como visto no capítulo anterior, é o tripé que compõe o jogo psicanalítico, como proposto por Lacan em seu Seminário 12, com os seguintes elementos: sujeito, saber e sexo. O outro tripé, extraído de Jerusalinsky e Sousa, acerca de quais as características ou capacidades que se poderia esperar de alguém que ocupa a posição de analista: primazia do significante, destituição narcísica e des-ser.

A partir desses elementos, demos início a essa articulação tomando como ponto de partida o aprendizado teórico, enquanto acesso a algo da ordem de um saber sobre a teoria psicanalítica. É certo que o estudo teórico tem papel decisivo na formação do analista e na sua capacidade de desenvolver um raciocínio clínico adequado a enfrentar as diversas situações clínicas que irão se apresentar. Sabemos da importância de que, na psicanálise, saber teórico e prática clínica estejam em constante interação. Nesse ponto, retomamos a relação entre sujeito e saber, para discutir qual o uso a ser feito desse saber teórico, em sua articulação com a prática clínica. É na capacidade do analista de reservar algum espaço de furo ou suspensão desse saber que se abre a possibilidade de que algo possa emergir da ordem do novo ou do inesperado, sendo essa a via para um uso da formação teórica que vise uma redução do potencial iatrogênico do tratamento. Ou seja, que o analista esteja advertido para que não coloque a teoria em posição de ideal, capaz de responder a todas as questões da clínica, o que, fatalmente, representaria uma cristalização da prática clínica, com efeitos iatrogênicos para o paciente. Ao poder suspender seu saber e estar aberto para o inesperado é que o analista é capaz de operar no sentido da primazia do significante, em sua escuta ao paciente.

Em seguida, seguimos por essa questão da articulação entre prática clínica e teoria psicanalítica, para avançarmos em direção à questão da supervisão, enquanto eixo de formação do analista. Vimos que a supervisão se mostra como lugar privilegiado para promover essa articulação entre prática clínica e teoria psicanalítica. Porém, para que isso ocorra de maneira produtiva, é necessário que a supervisão não se reduza a uma 
mera polarização entre sujeito e saber, ou seja, situação de mera comunicação de um saber que passa do supervisor para o supervisionando, reduzindo a supervisão a um acúmulo de saber por parte do supervisionando que, posteriormente, apenas aplicaria esse saber à prática clínica. Na psicanálise, a relação entre teoria e prática se articula de modo singular, de tal maneira que esses campos se retroalimentam mutuamente. Contudo, para que isso possa operar de modo adequado, é preciso que a supervisão possa se situar de modo também a promover algum tipo de abertura para algo além dessa dinâmica entre sujeito e saber, ou seja, para esse terceiro elemento que promove um furo no saber: o sexo.

Todavia, o acesso a esse terceiro elemento não é livre de implicações e vimos como, mesmo na supervisão, o trabalho é atravessado por importantes questões transferenciais, nas relações que se estabelecem entre supervisionando e supervisor. Assim, a fim de que a supervisão possa incidir no sentido de uma redução do potencial iatrogênico, é necessário que o supervisor esteja advertido da relação transferencial que estabelece com seu supervisionando, desde o momento em que lhe é endereçada a demanda de supervisão, evitando sustentar uma posição de maestria, de modelo ideal a ser copiado. Espera-se que o supervisor, mais do que ensinar, possa atuar de modo a possibilitar que o supervisionando possa desenvolver a capacidade de aprender a partir de sua própria experiência clínica.

É nesse sentido que destacamos um importante papel da supervisão, enquanto redutora de iatrogenias. Ao promover uma melhor articulação entre saber teórico e prática clínica, permite um melhor manejo da técnica, com redução do potencial de ocorrência de imperícias por imperícia. Ao permitir que o supervisionando possa constatar questões pessoais, narcísicas ou transferenciais, que possam estar atuando como obstáculos ao tratamento, reduz assim riscos de iatrogenias por negligência, ao colaborar para que o analista possa desenvolver sua capacidade de destituição narcísica no curso de um tratamento. Além disso, a supervisão, ao promover a possibilidade de que o supervisionando faça uma construção do caso clínico, permitem uma melhor apreensão do caso, em sua evolução e dinâmica temporal, com benefícios para que o supervisionando possa orientar sua tomada de decisões acerca das intervenções a serem 
realizadas em cada momento, com efeitos de redução também do potencial de ocorrência de iatrogenias por imprudência.

Por fim, partimos para o terceiro elemento do tripé da formação do analista: a análise pessoal. Vimos como a análise pessoal tem papel preponderante para $\mathrm{o}$ psicanalista. Pela relevância que essa experiência radical de análise tem para o sujeito, temos que ela produz efeitos que irradiam para todos os eixos já vistos acima, com ganhos no modo como o analista se relaciona com a teoria, no modo como conduz sua prática clínica e no modo como pode levar seus casos para supervisão. Desse modo, a análise pessoal teria efeitos de redução do potencial iatrogênico em suas três modalidades.

Contudo, optamos por centrar nosso debate em uma dimensão específica da análise pessoal: a possibilidade de colocar fim ao jogo na análise, ou seja, o ato analítico, enquanto experiência radical de um corte, que convoca o sujeito a efetuar sua redistribuição das apostas, com uma nova articulação entre sujeito, saber e sexo, e se situando de uma maneira mais pura ante seu desejo. Espera-se, assim, que o analista possa avançar o bastante em sua análise a fim de que possa se produzir algo de acesso a essa experiência, com emergência de seu desejo do analista. Vimos também que para que isso possa ocorrer, é necessário que o analista possa operar na condução do tratamento sustentando a ética da psicanálise, de modo que o ato analítico se faz a partir da possibilidade que o analista se desprenda de seu ser (seus aspectos pessoais, narcisismos ou gozos), para operar a partir de seu des-ser e de seu desejo de analista. Uma análise na qual o analista opera a partir do ser do analista representa maior potencial iatrogênico para o paciente, colocando-se como um obstáculo à cura. Nesse sentido, também uma análise de formação, caso conduzida a partir de aspectos pessoais do analista, não poderá alcançar efeitos produtivos de formação, o que produzirá um analista também incapaz de produzir um ato analítico na condução do tratamento, e assim perpetuando e agravando o potencial iatrogênico dos tratamentos.

Tais elaborações nos permitiram elaborar ainda um último tripé, a partir dos aspectos do analista que, caso venham a intervir excessivamente no tratamento, podem 
indicar um maior potencial iatrogênico para o tratamento: seus ideais, suas modalidades de gozo, e seu ser.

Assim, onde há um analista que atua excessivamente motivado por seus ideais, como no caso do analista que busca constantemente alcançar o reconhecimento de outros, ou então que vive oprimido por seus ideais, por exemplo ao crer que nunca poderá estar à altura dos méritos que supõe em seus mestres, ou, talvez o mais arriscado, o analista absolutamente identificado com seu ideal, que se acredita onipotente e incapaz de quaisquer erros ou falhas, muito provavelmente estaremos diante de uma situação com maior potencial de produção de iatrogenias.

No mesmo sentido, quando houver um analista que permite que sua satisfação pulsional, seu gozo, venha a se tornar um fator de influência no tratamento, seja ao se colocar como modelo de identificação para o paciente, ou como objeto de desejo. Ou ao adotar uma postura sádica, de quem goza com o sofrimento de seu paciente. Ou mesmo as modalidades mais sutis de gozo, que vimos nesse trabalho, como o do analista que goza da própria atividade de escuta e deciframento do inconsciente de seus pacientes. Mais uma vez estaremos diante de situações com maior potencial iatrogênico para os pacientes.

Por fim, os casos em que nos vemos diante um analista incapaz de se separar de seu ser, de promover essa separação radical resultante de uma experiência de pura diferença, atuará sempre no sentido de reforçar no paciente também essa incapacidade de separação, essa necessidade de se sustentar a partir da consistência do Outro e do saber suposto a ele. $\mathrm{O}$ efeito, muito provavelmente, será de uma análise sem, fim que jamais poderá alcançar a dimensão da cura, representando um efeito iatrogênico decisivo para o paciente.

Com a montagem desse tripé, de modo algum queremos sustentar que o analista seja aquele que conseguiu, de modo definitivo, se livrar de seus ideais, de seu gozo e de seu ser, vivendo sua vida livre dessas incidências. Mas espera-se sim que possa ser capaz de suspender tais incidências, quando se propõe a conduzir um tratamento. Mas para isso, não se trata de suspender definitivamente esses três elementos - o que seria 
impossível - a proposta é de que o analista possa estar advertido desses elementos, de seus ideais, de suas modalidades de gozo, de seu ser, e, mais do que isso, que possa estar bem resolvido com tais questões. Cremos que quando algo vai mal na vida do analista, fora do consultório, isso certamente irá reverberar também em sua prática clínica. E, no sentido contrário, a própria prática psicanalítica pode produzir efeitos iatrogênicos para o analista, com prejuízos para sua vida pessoal. Daí a importância da sugestão de que o analista, por mais experiente ou capacitado que seja, possa, sempre que necessário, retomar sua análise para tratar das questões pertinentes a seus ideais, suas modalidades do gozo ou, em última instância, seu ser.

Diante de todo exposto, entendemos que se faz necessário ainda mais uma consideração, acerca do uso desses diversos tripés, recorrentes na construção de nosso raciocínio. Vimos com Dunker, ao propor o tripé de clínica, terapêutica e cura, como paradigma para constituição da constituição da clínica psicanalítica, o alerta de que, apesar dessa divisão em três eixos, é necessário ter em mente desde o princípio que não se tratam de eixos isolados. Pelo contrário, os três elementos devem estar sempre articulados, considerando-se as relações entre eles. Desse modo, o uso do termo "tripé" nos parece produtivo, ao colocar justamente a ideia de três apoios, três bases que, juntas, possibilitam que algo seja sustentado, de tal modo que retirar alguma dessas bases, resultaria na queda do que era sustentado. Nesse sentido que, sobre esse tripé, Dunker afirma que perder algum dos três eixos seria perder a própria psicanálise.

Entendemos que esse raciocínio deva ser aplicado também aos outros tripés que utilizamos em nossos desenvolvimentos. Reduzir qualquer um desses tripés à apenas uma ou duas de suas dimensões, seria perder a própria função de sustentação promovida originalmente pelo tripé.

Mais do que isso, sustentamos aqui o argumento de que são justamente nas tentativas de redução desses tripés que podem ser localizados os maiores riscos de produção de iatrogenia. Uma terapia que se articula apenas entre sujeito e saber, sem considerar a dimensão do sexo. Uma formação de analistas que se foca excessivamente no saber teórico e supervisão com caráter didático, sem maiores considerações acerca das implicações da análise pessoal para a formação. Um analista que atua rigorosamente 
a partir da primazia significante, mas sem perceber sua incapacidade em se destituir narcisicamente e atuar a partir de seu des-ser. Poderíamos ainda pensar em outras possibilidades.

Mais uma vez retornamos a Freud (1937/1996), com a referência ao fracasso de Otto Rank ao tentar simplificar e encurtar o trabalho analítico. Podemos lembrar também do que vimos com Maleval, acerca das três grandes iatrogênicas nos EUA, causados por terapeutas que se apoderaram de partes da teoria psicanalítica, usando alguns de seus conceitos, para subsidiar uma prática simplificada, com efeitos catastróficos para os envolvidos.

$\mathrm{O}$ argumento aqui defendido e que podemos sustentar a partir da história da própria psicanálise, é de que tentativas de simplificação ou redução, recortes da prática, amputações do tripé, muito provavelmente irão resultar em práticas com maior potencial iatrogênico para os pacientes.

Se Lacan nos diz que o único erro do qual alguém pode ser responsabilizado é o de ceder diante do desejo, partimos disso e avançamos aqui para afirmar que as iatrogenias causadas são, no mais das vezes, resultantes de práticas ou praticantes que cederam diante dos desafios impostos pela clínica, na busca de atalhos, vias mais curta, mais imediatas ou mais fáceis, que recusam os desafios impostos pela dimensão do inconsciente e do desejo.

Mas, se nos propomos a sustentar essa posição, nos vemos também forçados a reconhecer que o presente trabalho ainda deixa vias em aberto, sobre as quais é necessário avançar. Especialmente em termos de uma investigação mais minuciosa acerca das relações que se estabelecem entre os elementos desses diversos tripés.

Estamos cientes da importância para a discussão de um avanço nesse sentido, e podemos reconhecer na literatura trabalhos que promovem essa discussão. No próprio Seminário 12, em suas últimas aulas, Lacan toma o conceito de Entzweiung e recorre ainda a outro tripé (Zwang, Sinn e Wahreit), para avançar na discussão acerca das três superfícies que se estabelecem entre cada uma das duplas possíveis a partir do tripé sujeito, saber e sexo, e as implicações que tais superfícies trazem para a prática 
psicanalítica. Também em Dunker (2011), vemos o trabalho minucioso de investigar cada uma das superfícies estabelecidas entre clínica, terapêutica e cura, em articulação ainda com as superfícies estabelecidas a partir dos elementos de um segundo tripé: Saber, Gozo e Verdade. Pelas limitações impostas pelo escopo de um trabalho de mestrado, não foi possível avançar nessa direção.

Vimos neste trabalho a importância de que o jogo possa também chegar, sendo esta a via para que seus efeitos sejam sentidos em todo seu alcance. Encerramos então este trabalho com a sensação de dever cumprido, ante os objetivos propostos originalmente, e com a aposta de que os efeitos aqui produzidos, nos despertarão o desejo de continuidade desta pesquisa, levando ainda a muitas outras partidas deste jogo. 


\section{REFERÊNCIAS BIBLIOGRÁFICAS}

Alberti, S., \& Elia, L. (2008). Psicanálise e Ciência: o encontro dos discursos. Revista Mal Estar e Subjetividade, 8(3), 779-802. Recuperado em 05 de março de 2016, de http://pepsic.bvsalud.org/scielo.php?script=sci_arttext\&pid=S1518$61482008000300010 \& \operatorname{lng}=\mathrm{pt} \& \operatorname{tlng}=\mathrm{pt}$

Alberti, S.; Amendoeira, W.; Lannes, E.; Lopes, A., \& Rocha, E. Ofício do psicanalista: formação versus regulamentação. São Paulo: Casa do Psicólogo, 2009.

Perry, C., Kuruc, J. W., (1993). Psychotherapists' Sexual Relationships with Their Patients. Annals of Health Law, Vol. 2, Article 4, p. 35-54

Balint, M. (1957). The doctor, his patient and the illness. (2rd ed.). London: Pitman Medical

Barlow, D. H. (2001). Clinical handbook of psychological disorders: A step-by-step treatment manual (3rd ed.). New York: Guilford Press

Barlow, D. H. (2010). Negative effects from psychological treatments: A perspective. American Psychologist, Vol. 65, no. 1, p. 13-20

Barreto, C. L., \& Morato, H. (2008). A dispersão do pensamento psicológico. Boletim de Psicologia, 58 (129), p. 147-160. Recuperado em 04 de maio de 2016, de http://pepsic.bvsalud.org/scielo.php?script=sci_arttext\&pid=S0006$59432008000200003 \& \operatorname{lng}=\mathrm{pt} \& \mathrm{t} \operatorname{lng}=\mathrm{pt}$

Barron, F. \& Leary, T. (1955). Changes in psychoneurotic patients with and without psychotherapy. Journal of Consulting Psychology, Vol. 19, no. 4, p. 239-245.

Bergin, A. E. \& Lambert, M. J. (1978). The evaluation of therapeutic outcomes. In: Garfield, S. \& Bergin, A. E., Handbook of Psychotherapy and Behavior Change, Wiley, New York

Bergin, A. (1963). The effects of psychotherapy: Negative results revisited. Journal of Counseling Psychology, Vol 10, no. 3, p. 244-250

Bergin, A. (1970). The deterioration effect: a reply to Braucht. Journal of Abnormal Psychology, Vol. 75, p. 300-302

Bergin, A. E. (1966). Some implications of psychotherapy research for therapeutic practice. Journal of Abnormal Psychology, Vol. 71, no. 4, p. 235-246.

Berk, M \& Parker, G. (2009). The Elephant on the Couch: Side-Effects of Psychotherapy. Australian and New Zealand Journal of Psychiatry, Vol. 43, p. 787-794

Beutler, L.E., Frank, M., Schieber, S.C., Calvert, S., \& Gaines, J. (1984). Comparative effects of group psychotherapies in a shortterm inpatient setting: An experience with deterioration effects. Psychiatry, Vol. 44, p. 67-76 
Bittar, C. (1991). Responsabilidade Civil Médica, odontológica e hospitalar. São Paulo: Editora Saraiva.

Bohart, A. C. (2007). The actualizing person. In: Cooper, M., O'Hara, M. , Schmid, P. F. \& Wyatt, G. (Eds.), Handbook of person-centred psychotherapy and counselling. New York: Palgrave Macmillan, p. 47-63

Bohart, A.C. (2000). Paradigm clash: Empirically supported treatments versus empirically supported psychotherapy practices. Psychotherapy Research, Vol. 10, p. $488-493$

Boisvert, C. M. \& Faust, D. F. (2007). Practicing psychologists' knowledge of general psychotherapy research findings: Implications for science-practice relations. Professional Psychology: Research and Practice, Vol. 37, no. 6, p. 708-716

Boston Change Process Study Group (2010). Change in Psychotherapy: A unifying Paradigm. New York: Norton

Brasil. Lei $n^{\circ} .8 .078$ de 11 de setembro de 1990. Dispõe sobre a proteção do consumidor e dá outras providências. Diário Oficial da República Federativa do Brasil, Brasília, DF, 12 de outubro de 1990. Disponível em: . Acesso em: 13.01.2007

Brusset, B. (1991). L'Or et le cuivre (La psychothérapie peut-elle être et rester psychanalytique?). In: Revue française de psychanalyse, Vol. 3, p. 565

Buckley, P., Conte, H.; Plutchik, R., Karasu, T. (1981). Psychotherapy Skill Profiles of Psychiatric Residents. Journal of Nervous \& Mental Disease, Vol. 169, , no. 11

Bulamah, L. (2014). História de uma regra não escrita: a proscrição da homossexualidade masculina no movimento psicanalítico. Dissertação de mestrado no programa de Pós-Graduação em Psicologia Clínica do Instituto de Psicologia da Universidade de São Paulo

Caffé, M. (2006). A Psicanálise no encontro com outras práticas institucionais. Saúde, Ética \& Justiça, Vol. 11, , no. 1-2, p. 36-44

Canguilhem, G. (1977). Ideologia e Racionalidade nas Ciências da Vida. Lisboa: Edições 70

Carkhuff, R. \& Truax, C. (1964). For better or for worse: The process of psychotherapeutic change. In Recent advances in behavioral change. Montreal: McGill University Press

Cartwright, D. S. (1956). Note on "changes" in psychoneurotic patients with and without psychotherapy. Journal of Consulting Psychology, Vol. 20, no. 5, p. 403404

Cartwright, R. D., \& Vogel, J. L. (1960). A comparison of changes in psychoneurotic patients during matched periods of therapy and no-therapy. Journal of Consulting Psychology, Vol. 24, no. 2, p. 121-127

Carvalho, J. (2009). Iatrogenia e Erro Médico sob o enfoque da Responsabilidade Civil. $3^{\mathrm{a}}$ ed. Rio de Janeiro: Lumen Juris 
Castonguay, L.G., \& Beutler, L.E. (2006). Principles of therapeutic change that work. New York: Oxford University Press

Castonguay, L; Boswell, J; Constantino, M; Goldfried, M; \& Hill, C. (2010). Training Implications of Harmful Effects of Psychological Treatments. American Psychologist. Vol. 65, no. 1, p. 34-49

Checchia, M.A. (2012). Sobre a política na obra e na clínica de Jacques Lacan. Tese de doutorado. Instituto de Psicologia da USP, São Paulo

Chiesa, M., Drahorad, C. \& Longo, S. (2000). Early termination of treatment in personality disorder treated in a psychotherapy hospital: A quantitative and qualitative study. British Journal of Psychiatry, Vol. 177, p. 107-111

Clarkin J. F., Levy K. N., Lenzenweger M. F., Kernberg O. F. (2004). Borderline Personality Disorder Research Foundation randomized control trial for borderline personality disorder: Rationale, methods, and patient characteristics. Journal of Personality Disorders, Vol.18 p. 52-72

Centro de Perícias Médicas e Saúde Ocupacional do Corpo de Bombeiros Militar do Estado do Rio de Janeiro (1999). Artigos: Iatrogenia. Recuperado em 26 de abril, 2016, do Website da CPMSO: http://www.cpmso.cbmerj.rj.gov.br/modules.php?name=Content\&file=print\&pid $=121$

Cournut, J. (1998). La psychanalyse dans le champ des psychothérapies. Société Psychanalytique de Paris, disponível em: www.spp.asso.fr

Couto, A.F. \& Souza, A.P. (1999). A improcedência no suposto Erro Médico. Editora Lumen Juris, $1^{\text {a }}$ Ed.

Crown, S. (1983). Contraindications and dangers of psychotherapy. The British Journal of Psychiatry, Vol. 143, p. 436-441

Dimidjian, S, \& Hollon, S. (2010) How would we know if psychotherapy were harmful?. American Psychologist, Vol. 65, p. 21-33

Doherty, W. J., Lester, M. E, \& Leigh, G. K. (1986). Marriage encounter weekends: Couples who win and couples who lose. Journal of Marital and Family Therapy, Vol. 12, p. 49-61

Dunker, C. (2011). Estrutura e constituição da clínica psicanalítica: uma arqueologia das práticas de cura, psicoterapia e tratamento. São Paulo, Annablume

Dunker, C (2015). O psicanalista é a presença do sofista em nossa época. In: Seminários sobre a obra de Lacan, Instituto de Psicologia da USP, São Paulo, 3 de junho de 2015, disponível em https://youtu.be/CCEAdyewJbA?list=PLlHDVKUxuaFrcHd_5HcSh_rdtYU9eYh $\mathrm{kA}$

Eaton, T. T., Abeles, N., Gutfreund, M. J. (1993). Negative indicators, therapeutic alliance, and therapy outcome. Psychotherapy Research, Vol. 3, p. 115-123 
Emmelkamp, P. M. G., de Haan, E., \& Hoogduin, C. A. L. (1990). Marital adjustment and obsessive-compulsive disorder. British Journal of Psychiatry, Vol. 156, p. 5560 .

Eysenck, H. J. (1952). The Effects of Psychotherapy: An Evaluation. Journal of Consulting Psychology, Vol. 16, p. 319

Fairweather, G. W., Simon, R., Gebhard, M. E., Weingarten, E., Holland, J. L., Sanders, R ., Stone, G. B., Reahl, J. E. (1960) Relative effectiveness of psychotherapeutic programs: A multicriteria comparison of four programs for three different patient groups. Psychological Monographs: General and Applied, Vol. 74, n. 5, p. 1-26

Fenichel, O. (1945). The Psychoanalytic Theory of Neurosis. London: Routledge and Kegan Paul

Ferenczi, S. (1920-1933). Sigmund Freud - Sandor Ferenczi. Correspondance. Paris: Calmann-Lévy, 2000

Ferreira, A. (1985). Pequeno Dicionário Brasileiro da Língua Portuguesa. Rio de Janeiro: Editora Nacional

Figueiredo, L. C. (1989). Matrizes do Pensamento Psicológico. Rio de Janeiro: Vozes

Fingermann, D. (2008). A análise dos analistas. Jornal de Psicanálise, Vol. 41, n. 74, p. 131-139

Foa E. B. \& Rothbaum B. A. (1998). Treating the trauma of rape: Cognitive behavioral therapy for PTSD. New York: Guilford Press

Foa, E. B. \& Emmkelkamp, P. M. (1983) Failures in behavioural therapy. New York: John Wiley and Sons.

Foerster, H. (1991). Ethique et cybernétique de second ordre. In: Systèmes, éthique, perspectives en thérapie familiale. Rey, Y. \& Prieur, B. (org.), Paris: ESF, p. 10-2

Fonagy, P. \& Roth, A. (2004). What Works For Whom? A Critical Review of Psychotherapy Research. Guilford, 2nd Edition

Forbes, J. (1990). A eficácia da Psicanálise: os finais do tratamento. In: Capítulos de Psicanálise - Biblioteca Freudiana Brasileira (coletânea)

Foucault, M. (1977a/2010). Poder e Saber. In: Ditos \& Escritos - vol. IV. Rio de Janeiro: Forense Universitária, p. 241-252

Foucault, M. (1977b/2010). Poderes e Estratégias. In: Ditos \& Escritos - vol. IV. Rio de Janeiro: Forense Universitária, p. 223-240

Foucault, M. (1978/2010). Dialogue sur le pouvoir. In: Dits et Écrits - vol. v. IV. Rio de Janeiro: Forense Universitária, p. 203-223

Foucault, M. (1979). Microfísica do poder. São Paulo: Edições Graal

Foucault, M. (1999). Problematização do sujeito: psicologia, psiquiatria e psicanálise. Rio de Janeiro: Forense Universitária

França, G. (1998). Medicina Legal. io de Janeiro: Guanabara koogan, $5^{\text {a }}$ ed. 
Frege, G. (1884). Os Fundamentos da Aritmética. São Paulo, Ed. Abril, 1983

Freud, S. (1950 [1895]/1996). Projeto para uma psicologia científica. In: Freud, S. Edição Standard Brasileira das Obras Psicológicas Completas de Sigmund Freud, Vol. I, Rio de Janeiro: Editora Imago

Freud, S. (1889/1996). Resenha de Hipnotismo, de August Forel. In: Freud, S. Edição Standard Brasileira das Obras Psicológicas Completas de Sigmund Freud, Vol. I, p. 109-121, Rio de Janeiro: Editora Imago

Freud, S. (1895/1996). Estudos sobre a histeria. In: Freud, S. Edição Standard Brasileira das Obras Psicológicas Completas de Sigmund Freud, Vol. II, Rio de Janeiro: Editora Imago

Freud, S. (1901/1996). Fragmento da análise de um caso de histeria. In: Edição Standard Brasileira das Obras Psicológicas Completas de Sigmund Freud, Vol. VII, Rio de Janeiro: Editora Imago

Freud, S. (1905/1996). Os chistes e sua relação com o inconsciente. In: Freud, S. Edição Standard Brasileira das Obras Psicológicas Completas de Sigmund Freud, Vol. VIII, Rio de Janeiro: Editora Imago

Freud, S. (1911/1996). O manejo da interpretação de sonhos na psicanálise. In: Freud, S. Edição Standard Brasileira das Obras Psicológicas Completas de Sigmund Freud, Vol. XII, Rio de Janeiro: Editora Imago

Freud, S. (1912a/1996). A dinâmica da transferência. In: Freud, S. Edição Standard Brasileira das Obras Psicológicas Completas de Sigmund Freud, Vol. XII, p. 110119, Rio de Janeiro: Editora Imago

Freud, S. (1912b/1996). Recomendações aos médicos que exercem a psicanálise. In: Freud, S. Edição Standard Brasileira das Obras Psicológicas Completas de Sigmund Freud, vol. XII, p. 147-159, Rio de Janeiro: Editora Imago

Freud, S. (1913/1996). Sobre o início do tratamento. In: Freud, S. Edição Standard Brasileira das Obras Psicológicas Completas de Sigmund Freud, Vol. XII, Rio de Janeiro: Editora Imago

Freud, S. (1914/1996). A questão da análise leiga. In: Freud, S. Edição Standard Brasileira das Obras Psicológicas Completas de Sigmund Freud, Vol. XIII, p. 173-248, Rio de Janeiro: Editora

Freud, S. (1914/1996). A história do Movimento Psicanalítico. In: Freud, S. Edição Standard Brasileira das Obras Psicológicas Completas de Sigmund Freud, Vol. XIV, p. 13-82, Rio de Janeiro: Editora Imago

Freud, S. (1916-17 [1915-17]/1996). Conferências introdutórias sobre psicanálise. Conferência XXVIII: Terapia analítica. In: Freud, S. Edição Standard Brasileira das Obras Psicológicas Completas de Sigmund Freud, Vol. XVI, p. 449-463, Rio de Janeiro: Editora Imago 
Freud, S. (1919 [1918]/1996). Linha de progresso na terapia psicanalítica. In: Freud, S. Edição Standard Brasileira das Obras Psicológicas Completas de Sigmund Freud, Vol. XVII, p. 173-181, Rio de Janeiro: Editora Imago

Freud, S. (1921/1996). Psicologia das massas e análise do eu. In: Freud, S. Edição Standard Brasileira das Obras Psicológicas Completas de Sigmund Freud, Vol. XVIII, Rio de Janeiro: Editora Imago

Freud, S. (1937/1996). Análise terminável e interminável. In: Freud, S. Edição Standard Brasileira das Obras Psicológicas Completas de Sigmund Freud, Vol. XXIII, Rio de Janeiro: Editora Imago

Ganaway, G. K. (1989). Historical truth versus narative truth: clarifying the role of exogenous trauma in the etiology of multiple personality disorder and its variants. Dissociation 2, pg. 205-220

Gaudenzi, P \& Ortega, F. (2012). O estatuto da medicalização e as interpretações de Ivan Illich e Michel Foucault como ferramentas conceituais para o estudo da desmedicalização. Interface - Comunicação, Saúde, Educação, Vol. 16, n. 40, p. 21-34

Gelso, C., Carter, J. (1985). The Relationship in Counseling and Psychotherapy: Components, Consequences, and Theoretical Antecedents. The Counseling Psychologist, vol. 13., n. 2, p. 155-243

Ghraiba, N. (2006). Adverse Effects and Iatrogenesis in Psychotherapy. Arabpsynet e Journal, Vol. 9

Gitelson, M. (1954). Therapeutic problems in the analysis of the 'normal' candidate. International Journal of Psychoanalysis, vol. 35, London

Grammaticos, P. C. \& Diamantis, A. (2008). Useful known and unknown views of the father of modern medicine, Hippocrates and his teacher Democritus. Hellenic Journal of Nuclear Medicine, Vol. 11, n. 1, p. 2-4

Greenson, R. (1967). The technique and practice of psychoanalysis.Vol. 1, New York: International Universities Press

Hadley, S. \& Strupp, H. (1976). Contemporary views of negative effects in psychotherapy. An integrated account. Archives of General Psychiatry, Vol. 33, n. 11, p. 1291-1302

Hans, H., Strupp, H., Suzanne, W., Hadley, B., \& Gomes-Schwartz, B. (1977). Psychotherapy for better or worse: the problem of negative effects. Universidade da Califórnia: Editora J. Aronson

Hans, L. A. (2000). Terapias sob suspeita: a psicanálise no século XXI. In: Pacheco Filho, R., et al. Ciência, pesquisa representação e realidade em psicanálise. Casa do Psicólogo, São Paulo

Hansen, N., Lambert, M., \& Forman, E. (2002). The psychotherapy dose-response effect and its implications for treatment delivery services. Clinical Psychology: Science and Practice. 
Hatfield, D., McCullough, L., Frantz, S. H. B., Krieger, K. (2010). Do we know when our clients get worse? An investigation of therapists' ability to detect negative client change. Clinical Psychology \& Psychotherapy, Vol. 17, p. 25-32

Henry, W. P., Strupp, H. H., Butler, S. E., Schacht, T. E., \& Binder, J. L. (1993). Effects of training in time-limited dynamic psychotherapy: Changes in therapist behavior. Journal of Consulting and Clinical Psychology, Vol. 61, p. 434-440

Henry, W. P., \& Strupp, H. H. (1994). The therapeutic alliance as interpersonal process. In: Horvath, A. O. \& Greenberg, L. S. (Eds.), The working alliance: Theory, research, and practice. New York: Wiley, p. 51-84

Henry, W. P., Schacht, T. E., \& Strupp, H. H. (1986). Structural analysis of social behavior: Application to a study of interpersonal process indifferential psychotherapeutic outcome. Journal of Consulting and Clinical Psychology, Vol. 54, p. 27-31

Hilliard, R. B., Henry W. P. \& Strupp H. H. (2000). An interpersonal model of psychotherapy: linking patient and therapist developmental history, therapeutic process, and types of outcome. Journal of Consulting and Clinical Psychology, Vol. 68, n. 1, p. 125-33

Holroyd, J. \& Brodsky, A. (1977). Psychologists' Attitudes and Practices Regarding Erotic and Nonerotic Physical Contact with their Patients. American Psychologist, Vol. 32, n. 10, p. 843

Hyman, M. (2001). When Psychoanalysis Becomes Illegal. Disponível em $<$ http://www.academyprojects.org/lehym3.htm>

Illich, I. (1975). A expropriação da saúde: nêmesis da Medicina. Rio de Janeiro: Nova Fronteira.

Jarrett, C. (2008). When Therapy Causes Harm. The Psychologist, Vol. 21, n. 1, p. 1012.

Jena, A, Seabury, S., Lakdawalla, D., Chandra, A. (2011). Malpractice Risk According to Physician Specialty. New England Journal of Medicine, Vol. 365, p. 629-636

Jones, W. (1868/2006). Hippocrates Collected Works I. Cambridge Harvard. University Press, retrieved September 28

Jorge, M. A. (2006). Lacan e a formação do psicanalista. Rio de Janeiro: Contra Capa

Jorgenson, L., Randles, R., \& Strasburger, L., (1991). The Furor Over PsychotherapistPatient Sexual Contact: New Solutions to an Old Problem. William Mary Law Review, Vol. 32, n. 3, p. 645-732

King, P. (1963). The unconscious exploitation of the 'bad parent' to maintain belief in infantile omnipotence. Trabalho não publicado, lido para a Psycho-Analytical Society

Kupermann, D. (2012). Um sonho de final de mestrado ou a transferência e o saber na institucionalização da psicanálise. TransFormações em Psicologia (Online), Vol. 4, n. 1, p. 119-136. 
Kupfer, C. Prefácio. In: Dunker, C. (2013) A psicose na criança: tempo, linguagem e sujeito. São Paulo: Zagodoni

Lacan, J. (1955/1998) Variantes do tratamento-padrão. In: J. Lacan, Escritos. Rio de Janeiro: Jorge Zahar

Lacan, J. (1958/1998). A direção do tratamento e os princípios de seu poder. In: J. Lacan, Escritos. Rio de Janeiro: Jorge Zahar

Lacan, J. (1959-1960/1997). O Seminário, livro 7: a ética da psicanálise. Rio de Janeiro: Jorge Zahar Ed.

Lacan, J. (1964/2003). Ato de fundação. In: Outros Escritos, Rio de Janeiro, Jorge Zahar Editor.

Lacan, J. (1964/1996). O Seminário, livro 11: os quatro conceitos fundamentais da psicanálise. Rio de Janeiro: Jorge Zahar Ed.

Lacan, J. (1964-1965/2006). O Seminário, livro 12: problemas cruciais para a psicanálise. Recife: Centro de Estudos Freudianos (publicação não comercial)

Lacan, J. (1967-1968). O Seminário, livro 15: o ato analítico. Inédito

Lacan, J. (1969-1970/1992). O Seminário, livro 17: o avesso da psicanálise. Rio de Janeiro: Jorge Zahar Editora

Lacan, J. (1976). O Seminário, livro 24: L'insu-que-sait de l'une-bévur s'aile a mourre [O Seminário, livro 24: O insucesso do inconsciente é o amor]. Inédito.

Lacan, J. (1967/2003). Proposição de 9 de outubro de 1967. In: J. Lacan, Outros Escritos. Rio de Janeiro: Jorge Zahar

Lambert, M. \& Ogles, B. (2004). The efficacy and effectiveness of psychotherapy. In: Lambert, M. J. (Ed.), Bergin and Garfield's handbook of psychotherapy and behavior change (5th ed.). New York: Wiley. p. 169-218

Lambert, M. (2007). What we have learned from a decade of research aimed at improving psychotherapy outcome in routine care. Psychotherapy Research, Vol. 17 , p. $1-14$

Lambert, M., Bergin, A, \& Collins, J. (1977). Therapist-induced deterioration in psychotherapy. In: Gurman, A. S. \& Razin, A. M. (Eds.), Effective psychotherapy: A handbook of research. Oxford, England: Pergamon Press

Laurent, E. (1999). O Analista Cidadão. Revista Curinga, Escola Brasileira de Psicanálise de Minas Gerais, n. 13, p. 07-13

Laurent, E. (1995). Versões da Clínica Psicanalítica. Rio de Janeiro: Jorge Zahar Editor

Lazarou, J., Pomeraz, B., \& Corey, P. (1998). Incidence of adverse drug reactions in hospitalized patients: a meta-analysis of prospective studies. The Journal of the American Medical Association, Vol. 279, n. 15, p. 1200-1205 
Leapel, L. (1992). Unnecessary Surgery. Health Services Research, Vol. 24, n. 3, p. $351-407$

Leite, N. \& Goldenberg, R. (2015). Dossiê psicanálise: marginal?. In: Revista Cult, edição 201, maio de 2015.

Levenson, J. C., Frank, E., Cheng, Y., Rucci, P., Janney, C. A., Houck, P., Forgione, R. N., Swartz, H. A., Cyranowski, J. M., \& Fagiolini, A. (2010). Comparative outcomes among the problem areas of interpersonal psychotherapy for depression. Depression and Anxiety, Vol. 27, n. 5, p. 434-440

Lieberman, M., Yalow, I., \& Miles, M. (1973). Encounter Groups: First Facts. New York: Basic Books

Lilienfield, S. (2007). Psychological Treatments That Cause Harm. Perspectives on Psychological Science, Vol. 2, n. 1

Lima, R. A. (2012). Foucault e a constituição histórica da questão do poder na clínica psicanalítica: considerações metodológicas. Dissertação de Mestrado, Instituto de Psicologia, Universidade de São Paulo, São Paulo

Linden, M. (2012). How to Define, Find and Classify Side Effects in Psychotherapy: From Unwanted Events to Adverse Treatment Reactions. Clinical Psychology \& Psychotherapy, Vol. 20, n. 3, p. 286-296

Loftus, E. \& Ketcham, E. (1994). Creating false memories. Scientific American, Vol. 277 , n. 3, p. $71-75$

Luborsky, L., Singer B., \& Luborsky. L. (1975). Comparative studies in psychotherapy: a review of quantitative research. Archives of General Psychiatry, Vol. 32, p. 995-1008

Mack, J. (1994). Abduction: Human Encounters With Aliens. New York: Ballantine

Maleval, J. C. (2004). A psicanálise provoca patologias iatrogênicas? In Miller, J. -A. (org.). Ornicar? 1. De Jacques Lacan a Lewis Carroll. Rio de Janeiro: Jorge Zahar

Maleval, J. C. (2009). A Extensão do Campo "psi” e suas Clivagens. Revista do Núcleo Sephora de Pesquisa sobre o Moderno e o Contemporâneo, Vol. IV, n. 7, UFRJ

Mays, D., \& Franks, C. (Eds.). (1985). Negative outcome in psychotherapy and what to do about it. New York: Springer

MD NEWS (2012). Medical Malpractice By the Numbers. Disponível em: http://www.mdnews.com/news/2012_03/national_april2012_medicalmalpractice.aspx

Meares, R. A., Hobson, R. F. (1977). The persecutory therapist. British Journal of Medical Psychology, Vol. 50, p. 349-359

Mezan, R. (2002). Interfaces da Psicanálise. São Paulo: Companhia das Letras

Miller, J.-A. (1992). Psicoterapia e Psicanálise. In: Psicanálise ou Psicoterapia, São Paulo, Papirus 
Mink, O. (1959). A comparison of effectiveness of nondirective therapy and clinical counseling in the junior high school. School Counselor.

Mohr, D. (1995). Negative outcome in psychotherapy: A critical review. Clinical Psychology: Science and Practice, Vol. 2, n. 1, p. 1-27

Moos, R. (2005). Iatrogenic effects of psychosocial interventions for substance use disorders: Prevalence, predictors, prevention. Addiction, Vol. 100, n. 5, p. 595604

Moraes, I. (2003). Erro médico e a Justiça. 5. ed. São Paulo: Editora Revista dos Tribunais

Moreira, L. E. V., Bulamah, L. C. \& Kupermann, D. (2014). Entre barões e porões: Amílcar Lobo e a psicanálise no Rio de Janeiro durante a ditadura militar. Analytica: Revista de Psicanálise, Vol. 3, n. 4, p. 173-200

Moretto, M. (2013). O que pode um analista no hospital?. São Paulo: Casa do Psicólogo

Mulhern, S. (1994). À la recherche du trauma perdu. Le trouble de la personnalité multiple. In: Assoun, P. -L. \& Zafiropoulos, M., La règle sociale et son au-delà inconscient, Paris, Anthropos, p. 237

Nathan, T. (1994). L'influence qui guérit. Paris, Odile Jacob, pg. 95

Nathan, T., (1998). Éléments de psychothérapie. In: Nathan, T., Blanchet, A., Ionescu, S. \& Zadje, N. Psychothérapies, Paris Odile Jacob, p. 12-13

Neumann, J. V. \& Morgenstern, O. (1953). Theory of games and economic behavior. Princeton, Princeton University Press

Nutt, D. \& Sharpe, M. (2008). Uncritical positive regard? Issues in the efficacy and safety of psychotherapy. Journal of Psychopharmacology, Vol. 22, p. 3

Padilha, K. (2001). Considerações sobre as ocorrências iatrogênicas na assistência à saúde: dificuldades inerentes ao estudo do tema. Revista da Escola de Enfermagem

Pascal, B. (1918, 1922/1954). Euvres completes. Paris, Gallimard; Pensees (ed. Havet) Paris, Delagrave

Pereira, A. (2000). Iatrogenia em cardiologia. Arquivo Brasileiro de Cardiologia, São Paulo

Pereira, O. (2003) O que é teoria?. São Paulo: Brasiliense

Phillip, D., Christenfeld, N., \& Glynn, L. (1998). Increase in US medication-error deaths between 1983 and 1993. Lancet, Vol. 351, p. 643-644

Pimentel, D., Araújo, M. G., \& Vieira, M. J. (2009). Final de análise: uma revisão sistemática da literatura. Estudos de Psicanálise, Vol. 32, p. 51-70

Pontalis J. B., Laplanche J. (1977). Vocabulário de psicanálise. Lisboa: Moraes editores 
Pope, K. S., \& Tabachnick, B. (1986). Sexual Attraction to Clients: The Human Therapist and the (Sometimes) Inhuman Training System. American Psychologist, Vol. 147, p. 151- 52

Pope, K. S., Levenson, H., \& Schover, L. (1979) Sexual Intimacy in Psychology Training: Results and Implications of a National Survey. American Psychologist, Vol. 24, p. 682-689

Powers, E., \& Witmer, H. (1951). An experiment in the prevention of delinquency. New York: Columbia University Press.

Rabinovich, D. (2000). O Desejo do Psicanalista: Liberdade e Determinação em Psicanálise. Rio de Janeiro, Companhia de Freud

Renik, O. (2001). The Patient's Experience of Therapeutic benefit. In: Psychoanalytic Quaterly, LXX

Resolução CFM No 1931/2009. Publicada no D.O.U. de 24 de setembro de 2009, Seção I, p. 90. Retificação publicada no D.O.U. de 13 de outubro de 2009, Seção I, p. 173

Rogers, C. R. \& Dymond, R. F. (1954). Psychotherapy and personality change. Chicago: University of Chicago Press

Rogers, C. R. (1961). A theory of psychotherapy with schizophrenics and a proposal for its empirical investigation. In Dawson, J. G. \& Dellis, N. P. (Eds.), Psychotherapy with schizophrenics. Baton Rouge: Louisiana State University Press.

Roudinesco, E. (1988). História da psicanálise na França - v.2. Rio de Janeiro: Jorge Zahar

Safouan, M. (1985). Jacques Lacan: e a questão da formação dos analistas. Porto Alegre, Artes Médicas

Santos, M. O. P.. (2012). Médicos e pacientes têm sexo e cor? A perspectiva de médicos sobre a relação médico-paciente na prática ambulatorial. Dissertação de Mestrado, Instituto de Psicologia, Universidade de São Paulo, São Paulo

Schreiber, F. R. (1971) Sybil: romance. São Paulo: Nova Epoca

Sigal, A. M. (2007). Notícias do campo Psicanalítico: Informe geral de nosso trabalho no movimento Articulação das Entidades Psicanalíticas Brasileiras. Jornal Digital dos Membros, Alunos e Ex-Alunos, nº 01, Junho de 2007 - Disponível em: http://www.sedes.org.br/Departamentos/Psicanalise/index.php?apg=b_visor\&pub $=01 \&$ ordem $=16$

Silvestre, D. (1989). A transferência é amor que se dirige ao saber. In: Miller, G. (org.) Lacan. Rio de Janeiro: Zahar Editor

Slochwer, J. (2010). As delinquências secretas do analista. Jornal de Psicanálise, São Paulo, vol. 43, n. 79

Smith, M., Glass, G., \& Miller, T. (1980). The benefits of psychotherapy. Baltimore: Johns Hopkins University Press 
Soler, C. (1989). Uma Terapeutica como não há outra. In Lacan, Gérar Miller (org.). Rio de Janeiro: Jorge Zahar Editor

Souza, S. (1997). A responsabilidade civil do médico na cirurgia meramente estética. Rio de Janeiro: CEPAD

Spanos, N. P. (1996). Faux souvernirs et désordre de la personnalité multiple. Bruxelas, De Boeck

Starfield, B. (2000). Is US Health Really the Best in the World?. Journal of the American Medical Association, Vol. 284, n. 4, p. 483-485

Steel, K., Gertman, P., Crescenzi, C., \& Anderson, J. (1981). Iatrogenic illness on a general medical service at a university hospital. Quality and Safety in Health Care, Vol. 13, n. 1, p. 76-80

Straton, D. (2004). Iatrogenic Dependency disorder. Australasian Psychiatry, Vol. 12, n. 1 , p. 69-71

Strupp, H. H. (1973). On the basic ingredients of psychotherapy. Journal of Consulting and Clinical Psychology, Vol. 41, n. 1, p. 1-8

Strupp, H. H., \& Hadley, S. W. (1985). Negative effects and their determinants. In: Mays, D. T. \& Franks, C. M. (Eds.), Negative outcome in psychotherapy and what to do about it, p. 20-55. New York: Springer.

Szasz, T. (1965). L'éthique de la psychanalyse. Paris, Payot, p. 96

Tavares, F. M. (2007). Reflexões acerca da iatrogenia e educação médica. Revista Brasileira de Educação Médica,, Vol. 31, n. 2, p. 180-185

Truax, C. (1963). Effective ingredients in psychotherapy. Journal of Counsulting Clinical Psychology, Vol. 46, n. 5, p. 1023-1035

Wallersteiin, R. R. (2001). La Trajectoire de la psychanalyse: où en-sommes nous aujourd'hui?. In: Revue française de psychanalyse.

Wampold, B. \& Brown, G. (2005). Estimating therapist variability: A naturalistic study of outcomes in managed care. Journal of Consulting and Clinical Psychology, Vol. 73, p. 914-923

Warren, J., Nelsom, P., Mondragons, S., Baldwin, S., Burlingam, G. (2010). Youth psychotherapy change trajectories and outcomes in usual care: Community mental health versus managed care settings. Journal of Consulting and Clinical Psychology, Vol. 78, n. 2, p. 144-55

WEBSTER (1993). Third new international dictionary. Springfield, MA: MerriamWebster. Disponível em: http://www.merriam-webster.com/dictionary/

Weiss, B., Catron, T., Harris, V., \& Phung, T. (1999). The effectiveness of traditional child psychotherapy. Journal of Consulting and Clinical Psychology. Vol. 67, n. 1, p. $82-94$ 
Weisz, J., Donenberg, G., Han, S., \& Launeckis, D. (1995). Child and adolescent psychotherapy outcomes in experiments and in clinics: Why the disparity?. Journal of Abnormal Child Psychology, Vol. 23, n. 1, p. 83-106

Wolberg, L.R. (1967). The Technique of Psychotherapy. Grune \& Stratton, New York

Zenoni, A. (1991). Le corps de l'être parlant. Bruxelas: De Boeck université

\section{Notícias}

G1 SP (2010), Roger Abdelmassih é condenado a mais de 200 anos de prisão. Disponível em http://g1.globo.com/sao-paulo/noticia/2010/11/roger-abdelmassihe-condenado-mais-de-200-anos-de-prisao.html

G1 PR (2013). Médica é indiciada por homicídio qualificado em UTI de hospital. Disponível em http://g1.globo.com/pr/parana/noticia/2013/02/mortes-na-uti-doevangelico-podem-ser-homicidio-qualificado-diz-delgada.html

Jornal da Paraíba (2010). Conselho de Psicologia se manifesta sobre caso de acusado de pedofilia. Disponível em: http://www.jornaldaparaiba.com.br/cidades/noticia/53412_conselho-depsicologia-se-manifesta-sobre-caso-de-acusado-de-pedofilia

Schlesinger, F. (2010) Top Harley Street psychiatrist 'preyed on patients for sex and groomed suicidal woman'. Mail Online News. Disponível em: http://www.dailymail.co.uk/news/article-1299697/Psychiatrist-Theodore-Soutzospreyed-patients-sex-groomed-suicidal-woman.html

\section{Links Consultados:}

http://lacaneando.com.br/christian-dunker/

Staferla.free.fr

http://kff.org/ 